\title{
Physiotherapist's consultation in general practice
}

Citation for published version (APA):

Hendriks, H. J. M. (2000). Physiotherapist's consultation in general practice. [Doctoral Thesis, Maastricht University]. Universiteit Maastricht. https://doi.org/10.26481/dis.20001124hh

Document status and date:

Published: 01/01/2000

DOI:

10.26481/dis.20001124hh

Document Version:

Publisher's PDF, also known as Version of record

\section{Please check the document version of this publication:}

- A submitted manuscript is the version of the article upon submission and before peer-review. There can be important differences between the submitted version and the official published version of record.

People interested in the research are advised to contact the author for the final version of the publication, or visit the DOI to the publisher's website.

- The final author version and the galley proof are versions of the publication after peer review.

- The final published version features the final layout of the paper including the volume, issue and page numbers.

Link to publication

\footnotetext{
General rights rights.

- You may freely distribute the URL identifying the publication in the public portal. please follow below link for the End User Agreement:

www.umlib.nl/taverne-license

Take down policy

If you believe that this document breaches copyright please contact us at:

repository@maastrichtuniversity.nl

providing details and we will investigate your claim.
}

Copyright and moral rights for the publications made accessible in the public portal are retained by the authors and/or other copyright owners and it is a condition of accessing publications that users recognise and abide by the legal requirements associated with these

- Users may download and print one copy of any publication from the public portal for the purpose of private study or research.

- You may not further distribute the material or use it for any profit-making activity or commercial gain

If the publication is distributed under the terms of Article $25 \mathrm{fa}$ of the Dutch Copyright Act, indicated by the "Taverne" license above, 


\section{Physiotherapist's Consultation in General Practice}


CIP-DATA KONINKLIJKE BIBLIOTHEEK, DEN HAAG

2000 Erik [HJM] Hendriks

Physiotherapist's consultation in general practice /

Henricus Johannes Maria Hendriks. - [S.1 : s.n.]

Thesis Maastricht University - With summary in Dutch

ISBN 90-73054-92-3

Subject headings: consultation - diagnosis - physiotherapist - general practice - observational study - patient profiles - referral pattern - utilization - determinants

Lay-out: Erik Hendriks

Cover: Erik Hendriks - Ponsen \& Looijen bv

Production: Ponsen \& Looijen bv, Wageningen

The studies presented in this PhD thesis were performed at the Netherlands Institute of Primary Health Care (Nivel, Utrecht) and the Dutch National Institute of Allied Health Professions (NPi, Amersfoort). The Nivel participates in the Netherlands School of Primary Care Research (CaRe), which was acknowledged in 1995 by the Royal Dutch Academy of Science (KNAW).

The studies were supported by grants from the Dutch Ministry of Health, Welfare and Sports (VWS) (grant-number DGVZ/AGZ/ELZ/119007) and the participating health insurance companies CZ groep Zorgverzekeringen, Zorgverzekeraar VGZ and Zorgverzekeraar Zorg en Zekerheid. 


\section{Physiotherapist's Consultation in General Practice}

\section{Proefschrift}

ter verkrijging van de graad van doctor aan de Universiteit Maastricht, op gezag van

de Rector Magnificus Prof. dr. A.C. Nieuwenhuijzen Kruseman volgens het besluit van het College van Decanen,

in het openbaar te verdedigen op vrijdag 24 november 2000 om 12,00 uur door

Henricus Johannes Maria Hendriks geboren op 28 september 1958 te Veldhoven 


\section{Promotores}

Prof.dr. J van der Zee

Prof.dr. RAB Oostendorp

(Katholieke Universiteit Nijmegen)

Prof.dr. J Dekker

(Vrije Universiteit Amsterdam)

\section{Beoordelingscommissie}

Prof.dr. HFM Crebolder

(voorzitter)

Prof.dr. WJA van den Heuvel

Prof.dr. RM Nelson

(Thomas Jefferson University, Philadelphia US)

Prof.dr. C Spreeuwenberg

Dr. A de Wijer

(Universiteit Utrecht)

Financial support by Nivel, NPi, the Royal Dutch Physiotherapy Association (KNGF), CZ groep Zorgverzekeringen, Zorgverzekeraar VGZ and Zorgverzekeraar Zorg en Zekerheid for the publication of this thesis is gratefully acknowledged. 
Voor Jenny en onze kinderen Michelle, Simone en Nadine 



\section{Contents}

PART I Introduction

Chapter 1 Physiotherapist's consultation in general practice:

introduction to study

Chapter 2 The diagnostic process and indication for physiotherapy:

a prerequisite for treatment and outcome evaluation

Chapter 3 Consultation between general practitioners and medical

consultants in the Dutch health care system.

What can we learn from the literature?

PART II Preliminary Studies, Research Questions, and Design of the Study

Chapter 4 Experiences with physiotherapist's consultation: results of a feasibility study

Chapter 5 Intraobserver and interobserver reliability of assessments of impairments and disabilities

Chapter 6 Physiotherapist's consultation in general practice:

PART III Results of the Study

Chapter 7 Physiotherapist's consultation in general practice:

its use and effect on process of care

Chapter $8 \quad$ Patterns of utilization and efficiency of care following a one-time physiotherapist's consultation in general practice

Chapter 9 Determinants of the number of sessions per physiotherapy treatment episode

PART IV Discussion \& Summary

$\begin{array}{lll}\text { Chapter } 10 & \text { General discussion } & 187\end{array}$

Summary 207

Samenvatting $\quad 213$

References 219

List of publications and presentations of the study 239

Appendices 241

Dankwoord 257

Curriculum vitae $\quad 261$ 



\section{PART I}

\section{Introduction}





\section{Physiotherapist's Consultation in General Practice Introduction to the Study}

The current policy of Dutch primary health care is to provide accessible and high-quality care. ${ }^{1-3}$ Cost containment, however, is a central issue in health care policies all over the world, and is often the aim of Dutch policy initiatives and directives.$^{3-6}$ This emphasis on cost containment directly affects physiotherapeutic care and requires that physiotherapists make choices in the provision of care, and help develop strategies that will improve the quality, outcome and efficiency of that care. ${ }^{7-9}$

Since $80 \%$ of the patients in physiotherapy practices in primary care are referred by general practitioners (GPs), ${ }^{10-12}$ close cooperation between GPs and physiotherapists is very important. The most common health problems that are presented to GPs are disorders of the locomotor system. ${ }^{8-17}$ One out of every four patients with health problems or disorders of the locomotor system is referred to a physiotherapist or medical specialist for further treatment. ${ }^{13-15}$

Within primary care, treatment referrals are most often made to physiotherapy. ${ }^{12}$ Thus, physiotherapy plays an important role in the therapeutic options available to GPs. ${ }^{12: 16}$ In the average Dutch GP's practice (2350 patients), approximately 270 patients are referred to a primary care physiotherapist each year. ${ }^{\text {note }}{ }^{1}$ This high rate of referral for patient treatment demands a good working relationship between GPs and physiotherapists. However, several problems have been identified concerning GPs" working relationship with physiotherapists. These problems include: poor communication: ${ }^{12.21-26}$ lack of knowledge about physiotherapy, ${ }_{,}^{12,26-30}$ uncertainty about indications for referral ${ }_{n}^{3,12,21-24}$ and doubt about the efficacy of physiotherapy. ${ }^{3.9,23.24,30,31}$

In the Dutch health care system, GPs occupy a pivotal position in the provision of primary care and coordination of continuing care. ${ }^{3,4,32,33}$ Because most health services are only accessible through written referral from GPs, the GP functions as a gatekeeper to various health care services. This pivotal position demands that GPs have a thorough knowledge of the indications for other health professionals and be highly skilled in determining a patient's need for a one-time consultation or treatment by other health care professionals. 
It is proposed that the communication between GPs and physiotherapists, and ultimately patient care, could be improved through the provision of a one-time patient consultation by physiotherapisis. ${ }^{8,12,27.28 .34}$ If the GP is in need of further diagnostic information on the patient's functional status or is uncertain whether or not physiotherapy is the best treatment choice for the patient, (a one-time) physiotherapist's consultation may provide useful information to the GP and help determine the optimal patient treatment plan.

This chapter presents the background, objectives and scope of the thesis "Physiotherapist's Consultation in General Practice".

\section{Physiotherapy in the Dutch Primary Health Care System}

The total number of active physiotherapists in the Netherlands is 16,000 . Approximately one third practice within institutions (public and private clinics, rehabilitation clinics and nursing homes). ${ }^{18-20}$ These figures represent one full-time equivalent physiotherapist in general practice per every 1,750 peopie. Health surveys from the Central Bureau of Statistics (CBS) show that each year slightly more than $15 \%$ of the Dutch population have one or more treatment sessions from physiotherapists (exclusive of the contact during hospital admission) ${ }^{18,19,35.36}$ In the period from 1981 through 1990 , each year $6.6 \%$ to $14.3 \%$ of the general population had contact with a physiotherapist. Since 1990 , this percentage has stabilized to approximately $15 \%$. The total cost of physiotherapy is approximately 1.2 billion guilders (about $2 \%$ of the total cost of health care). ${ }^{18-20.35 .36}$

Reimbursement of physiotherapy services requires a written referral by a physician. The remuneration system for physiotherapy services was changed in 1996. For publicly insured patients, the maximum number of sessions per indication per year was restricted to nine (except for pediatric physiotherapy, for which the maximum number is 18 ). There is no restriction on the maximum number of treatment sessions for some categories of insured patients with a medically defined chronic condition. An additional number of nine sessions is reimbursed for patients with complementary insurance, resulting in a maximum number of 18 sessions allowed per indication per year.

\section{Professional regulation}

Untili recently, the relationship between physician and physiotherapist in the Netherlands has been regulated by the Law on Allied Health Professions. ${ }^{37}$ Since the 1st of December 1997, the profession of physiotherapy is subject to regulation under the B.I.G. Act (Wet Beroepen in de Individuele Gezondheidszorg), ${ }^{38}$ and the Law on Allied Health Professions was lapsed. The Physiotherapy Act $(1977)^{39}$ only speaks of referral by physicians to physiotherapisis for the purpose of treatment. Under the new regulation, access to physiotherapy will remain restricted to a written referral by a physician. The written referral from physician to physiotherapist gives the physician full responsibility for stating the indications for patient treatment. Without clearly stated indications, there can be no 
referral. The concept underlying indication settings has been defined as the extent to which the professional (in this case the GP) is able to decide "what care may be required and which disciplines, areas of expertise, and equipment, may best serve the needs of the patients. ${ }^{n 0}$ According to the Health Services Act (1966), ${ }^{41}$ an indication exists when treatment is expected to result in "cure, or at least, amelioration (also including reduction of pain), and the maintenance of optimal physical condition in the event of ill health or disability."

In the Dutch medical profession, interventions acknowledged as part of physiotherapists' expertise are the examination and evaluation, diagnosis and prognosis, and treatment of patients. Patient treatment may be provided through application of physiotherapeutic methods (i.e., exercise therapy, massage, and electrotherapy), and through advice or education to the patient (i.e., information on disease prevention, suggested behavioral changes with regard to health, and instruction regarding the need to adhere to therapy).

\section{Changes in medical referral}

Medical referral to physiotherapy has been investigated from both quantitative and qualitative perspectives. Quantitative studies of referral are related to the decision to refer, ${ }^{1 "}$ and the utilization of physiotherapy services (e.g., the restriction of the length of the treatment episode, and the number of treatment sessions), ${ }^{9}$ whereas qualitative studies are focused on the written contents or characteristics of the referral itself. Qualitative examination of referral can be used as an indicator of professional change. Characteristic of the development of the relationship between GP and physiotherapist is the identified change from prescriptive to non-prescriptive referrals. ${ }^{42,43}$ This development indicates not only a change in the relationship between GP and physiotherapist, but also a substantial change within the profession of physiotherapy. A prescriptive referral signifies a prescription with a specific written treatment plan that both the GP and physiotherapist expect to be carried out. This prescription assumes the GP has sufficient knowledge about physiotherapy to make a choice between physiotherapeutic methods.

In the non-prescriptive referral, the GP evaluates the patient, makes a medical diagnosis, and determines that physiotherapy may be helpful in the management plan. Nonprescriptive referrals give the physiotherapist responsibility for the direction of treatment. The physiotherapist bases the treatment plan (including strategy and modalities) on his or her own history-laking, a physical examination/evaluation of the patient, and the documented physiotherapy diagnosis.

A potential advantage of non-prescriptive referral is the greater professional responsibility of the physiotherapist to help determine the specific physiotherapy intervention and management plan. It is important to note that a non-prescriptive referral does not imply an unlimited duration of physiotherapy. Because of the need for an integrated total management plan, physiotherapists must communicate their treatment plan to the referring GP. It is assumed that the GP is aware of the likely outcome of therapy, but this does not apply to aspects of the proposed treatment modalities. 
The physician should be able to rely on the expertise of the physiotherapist for proposing a treatment, and a prognosis (including a prognosis for recovery, the number of sessions, and the length of the treatment period). It is the responsibility of the physiotherapist to provide the ways and means of physiotherapeutic intervention.

Due to the increase in non-prescriptive referrals, physiotherapeutic care processes in the Netherlands have expanded from being merely executive into diagnostic/interventional, or suppoit areas.

\section{Cooperation}

Van Dale ${ }^{44}$ defines cooperation as "jointly working at the same task." This implies that people not only work toward the same objective, but also synchronize their activities. The objective of care, therefore, must refer to the content of the care provision, or have conditional importance. De Melker considers cooperation to be: "mutually attuned behavior regarding the division of tasks and activities. "45,46 This division requires coordination, and agreement for accepting or delegating aspects of the work respectively. Frequent and structured consultation is an essential part of mutual cooperation. 9.26,27.45,46

The subject of cooperation in primary health care has been an important focus of interest for some years. ${ }^{47-49}$ The two most important reasons for this are: (1) the need for an integrated approach toward health deficiencies, and (2) the need for an increase in the potential for treating patients in primary health care. In the policy memorandum Note2000 , it is stated that continuity and quality of care have been insufficiently realized due to the lack of structured cooperation, clear working agreements, division of tasks, and consultation between core disciplines working in the provision of primary and secondary health care. ${ }^{48}$ Consultation between health care workers is important in establishing a joint treatment plan and avoiding mutual ignorance among disciplines. The professional abilities of workers in the various disciplines in primary care must be complementary and coordinated. This demands mutual insight into expertise and work methods.

\section{Bottlenecks in cooperation}

Research has shown that there are several bottlenecks in the cooperation between Dutch GPs and physiotherapists (Table 1). ${ }^{10,12.21-27}$ Although both GPs and physiotherapists are convinced of the importance of cooperation, there is little evidence of it in daily practice. One of the causes may be the elevation of the ideology of cooperation into a dogma, resulting in cooperation as a means being confused with cooperation as a goal. Cooperation is, however, not a goal in itself, but rather provides the opportunity to improve patient care. The cooperation between GPs and physiotherapists can be merely characterized as "working apart together." 
Table 1. Inventory of the bottlenecks in cooperation between GPs and physiotherapists"

Bottlenecks identified by GPs:

- The physiotherapist puts pressure on the GP with respect to the referral, the number of treatments, and/or the need for continuation of treatment

- The physiotherapist acts on the findings from the physiotherapeutic examination and disregard the prescribed treatment policy

- There are often unclear indications for referral

- It is unclear what kind of information (referral data) is necessary for appropriate referral

- The physiotherapist's (interim) report gives too much general information and too litile specific information

- GPs have doubts about the diagnostic skills of physiotherapists and the efficacy of physiotherapy

- The physiotherapist often treats patients for too long

- GPs frequently work with a number of different physiotherapists

- There is concern that physiotherapy treatments might further the process of somatic fixation

- There is often intra-disciplinary variation in physiotherapists" management strategies

Bottlenecks identified by physiotherapists:

- The GP's written referral is often unreadable and provides insufficient relevant information

- The physiotherapist is not allowed enough freedom fully to use his or her specific expertise

- The physiotherapist is not consulted for advice often enough

- Patients are temporarily "parked" by the GP without any mention of this to the physiotherapist

- The physiotherapist is financially dependent on the GP

- The physiotherapist works with (too) many GPs

- It is difficult to communicate with GPs by telephone

- The physiotherapist does not receive a response to an interim report

Bottlenecks identified by both GPs and physiotherapists:

- Extensive mutual ignorance about the knowledge and expertise of the other prevails. Phyșiotherapists ștate that GPs frequently have (too) little knowledge about the scope and breadth of physiotherapy

- GPs lose track of the large diversity of physiotherapy treatment modalities and processes. Points of đeparture may differ, but this is mutually unfamiliar territory for both GPs and physiotherapists. Each lack knowledge of each other's practices.

- GPs and physiotherapists use different management approaches to patient disorders

- The professional jargon differs

- There is a lack of suppon in the sense of education and training

- A lack of clarity prevails about responsibility for the coordination of integrated care. An overlap ef care provision is frequently observed

- (Unremunerated) time is the cost of better cooperation and communication

- From: van der Rijdt et al ${ }^{20}$ supplemented or confirmed by findings from Hendriks et al. ${ }^{27.28}$

Because of the policy of referral, GPs have a profound influence on the patient population receiving physiotherapy. ${ }^{50}$ Together with the patient, GPs determine the outcome of referral on the basis of their own expertise and their knowledge as to both the total number of patient treatment referrais to physiotherapists, and the available physiotherapeutic options. Research has shown that a highly variable condition exists in both the total number of patient treatment referrals to physiotherapists, as well as the types of patient disorders and health related problems referred from GPs. ${ }^{11=14,51,52}$ Furthermore, GPs often express doubt concerning the efficacy of physiotherapy. ${ }^{3.23,30,31}$ 
Table 2. Conceptual framework for the quality of professional practice ${ }^{a}$

I. Quality of methodical-technical practice, specifying aspects of:

- effectiveness/efficacy

- expertise

- indication

- suitability

- safety/satisfaction

- care/vigilance

II. Quality of the attitudes of the professionals accentuating:

- respectful attitude

willingness to impart (supply) information

relationship of trust

cooperation

ready accountability

III. Quality of professional organization accentuating:

- continuity

- availability

- efficiency

- Adapted from the NRV"

From the results of the project Cooperation Between General Practitioner and Physiotherapist, it is clear that adequate referral is often difficult to achieve, due to the limited knowledge GPs have about the nature and working methods of physiotherapeutic management. ${ }^{26}$ An orientation study on the necessity of physiotherapy shows large differences in judgment between GPs and physiotherapists. ${ }^{31}$ In that study, the same judgment on referral to physiotherapy was found in only $43 \%$ of cases. The authors recommended that better communication be initiated between GPs and physiotherapists in order to better define the indications for physiotherapy, and that further contact be made as soon as the physiotherapist has examined the patient.

In the present situation, GPs decide on the basis of a medical diagnosis/symptom diagnosis whether or not there is an indication for physiotherapy. A study among GPs $(n=250)$ revealed that, on the point of indication setting, 4 out of 10 considered their knowledge about physiotherapy to be insufficient, and almost ail thought that, after graduation, they had insufficient knowledge about physiotherapy. ${ }^{10.12,26}$ Accordingly, the physiotherapist had to examine and diagnose the patient before physiocherapy treatment could be commenced. Although a medical diagnosis and additional referral data are important, they are often non-specific in directing treatment in today's physiotherapy practice. ${ }^{12.27 .28 .53-58}$ The medical diagnosis and/or the referral data are used as a point of departure for the physiotherapeutic examination/evaluation and assessment. However, physiotherapeutic management does not primarily focus on the disease itself, but rather on the functional status of the patient, and more importantly, on deciding the direction and goals of treatment. ${ }^{12.53 \cdot 58}$ Also, the quality of referrals from both GPs and medical specialists are 
felt to constitute a bottleneck. ${ }^{3.59}$ Information is frequently lacking with regard to (joint) policy, patient's status, prognosis, reasons for and expectations of the referral ${ }^{3.9}$

Developments in the profession of physiotherapy do not make it easy for GPs and medical specialists to stay informed about specific expertise within physiotherapy. A further bottleneck in cooperation between these two disciplines is in the relatively small provision of GP and physiotherapy practices. ${ }^{10.12,26,28}$ This means that, with the exception of small residential areas, most areas contain numbers of GPs and physiotherapists practicing separately. Taking this situation into consideration, it seems plausible that a GP refers patients to several physiotherapy practices, and a physiotherapy practice may receive referrals from several GPs.

Such a (structural) situation has a negative effect on the degree of communication and cooperation between GPs and physiotherapists. Accordingly. GPs often find cooperation with physiotherapists to be less important than that with other primary care disciplines, such as district nurses, social workers, and pharmacists. ${ }^{10,12,26}$

\section{Strategy to improve cooperation}

Bertels et $a^{60}$ stated that physiotherapy could be used more appropriately if physiotherapeutic expertise were introduced earlier in the contacts between GPs and patients. Kerssens \& Curfs $^{12}$ concluded that GPs acquire improved insight into the possibilities of physiotherapy through intensive cooperation with physiotherapists.

A solution may be found in a formal consultation with a physiotherapist prior to a (potential) referral for treatment in cases where the GP is uncertain about the appropriateness of the indication for physiotherapy and/or about physiotherapeutic options. $^{8,11,12,27,28}$ It can be stated that the GP's policy may benefit from consultation prior to referring certain patients to the physiotherapist for treatment. This supposition is supported by Kerssens et al. ${ }^{10 \cdot 12}$ That study shows that GPs sometimes use the expertise of physiotherapists in the diagnosis of cases. Most GPs (183 out of 250 [73\%]) think it desirable to extend the opportunities to refer to physiotherapists for consultation.

In the policy memorandum "Note on the Development of Physiotherapeutic Care", it is stated that policy will focus on the initiation of projects that contribute to improved communication structures, information exchange, and consultation between GPs and physiotherapists. ${ }^{7}$ This study into the effects of referral to a physiotherapist for a one-time consultation is consistent with that policy. By enabling GPs to consult physiotherapists early in the diagnostic process, a new dimension will be added to the relationship between GPs and physiotherapists.

In theory, physiotherapist's consultation could be instrumental in enhancing the quality and utilization of care, particularly if the GP is uncertain whether physiotherapy would be beneficial for a specific patient. Hence, the communication between professionals and a philosophy of shared care may be instituted. However, it is difficult to achieve unanimity regarding the definition of the broad concept of quality of care. 
Using the conceptual framework developed by the National Council for Public Health (NRV), ${ }^{61,62}$ quality can be defined at the levels of methodical-technical action, attitude, and organization of the professional (Table 2). At all three leveis, a one-time physiotherapist's consultation can make a positive contribution to the quality of professional practice.

\section{A Bird's-eye View of Consultation}

Consultation is the practice of intra- or interdisciplinary cooperation where one health professional requests an opinion from another health professional. ${ }^{27.63-67}$ Consultation should be patient-specific. The person requesting consultation may have different reasons for consultation, such as the need for additional information on diagnosis (unclear diagnosis) and/or advice/recommendations for treatment policy (undetermined or unsuccessful treatment); uncertainty of the appropriateness and necessity of referral; a request by the patient; the need for reassurance of the patient (and related persons); and a failed relationship with the patient. ${ }^{27,63 \cdot 67}$ Furthermore, the person requesting consultation is usually interested in the continuation of patient care after the consultation is obtained. Within medical practice, a referral to another physician involves the transfer of responsibility to another physician for the care of a specific patient problem. The consultant should remember that following consultation, it is the expectation of the referring physician (requesting the consultation) that the patient will have a follow-up appointment. Accordingly, the consultani is expected to report the outcome of the consultation to the referring physician (the consultee), via a letter or telephone call, within an appropriate time. An explicit consultation procedure between the referring and consulting physician is extremely important in insuring that the desired results are obtained. ${ }^{27.50,63-67}$ If this process is flawed, the patient, the referring physician or consultant may become dissatisfied with the results, and the benefit to patient care may be less than desired. Poor communication among the person requesting consultation, the consultant, and the patient may decrease the quality of patient care and lead to disappointment. Good communication is essential to ensure a positive result from consultation, and to improve overall communication between different health care professionals.

\section{Physiotherapist's consultation}

The situation regarding referral between the GP and physiotherapist is not entirely comparable to the referral situation between the GP and medical specialist. GP referral to a medical specialist often involves a transfer of treatment responsibility to the medical specialist, ${ }^{12.27}$ but this is not the case for referral to physiotherapy. However, the opportunity to consult the physiotherapist does share some clear similarities with the referral situation between GP and medical specialist. 
Therefore, findings from the research literature concerned with referrals by GPs to medical specialists have served as a model for the development of the process of consultation, ${ }^{63-88}$ the referral letter, ${ }^{89}$ the physiotherapist's report and documentation ${ }^{90}$

In this present study, consultation means that the GP can ask the physiotherapist for advice over a specific problem concerning a specific patient. As with any consultation, the originator of the request retains final responsibility for decisions and continuity of care. ${ }^{27.50,63-68}$ This is of crucial importance to the GP as gatekeeper of health care services. ${ }^{3.6,32.33}$

Referring depends, among other things, on personal views, attitudes, and experience. The process of physiotherapist's consultation holds the expectation that the GP will make more appropriate use of the professional expertise of the physiotherapist. Through consultation, the GP gains information about the indications for physiotherapy, and the treatment options in primary care. Subsequently, the GP will be able to make more considered referrals, and better adapt the course of patient treatment.

Communication between GP and physiotherapist is essential in order to develop a treatment plan for which both professions feel a heightened sense of mutual responsibility. A potential advantage of consultation is a greater acknowledgment of each professional's contribution to patient care, which can improve job satisfaction and encourage intellectual creativity. A potential disadvantage of consultation is the possible conflict resulting from differences of opinion or misunderstood communication. Furthermore, the overlapping of roles can lead to conflict if role negotiation and role responsibility are not agreed upon. Another potential disadvantage is the increased time required for consultation and communication. Physiotherapist's consultation in the context of this study was defined as "a written request by a GP to a physiotherapist to examine and evaluate a patient, to generate information regarding diagnosis and prognosis to facilitate the treatment plan of the GP, specifically when it concerns the possibilities for physiotherapeutic interventions." Consultation is not intended to create free access to physiotherapy. Consultation only takes. place at the request of a GP. Further, it should be noted that the physiotherapist consulted cloes not automatically become the physiotherapist providing treatment if the GP decides. to refer the patient to physiotherapy.

\section{Objective and Research Questions}

The main objective of the present thesis is to establish whether consultations provided by physiotherapists to GPs will qualitatively and/or quantitatively influence the number of patient referrals made by GPs to medical specialists and physiotherapists (e.g. referral patterns).

In this context, the core research question can be formulated as follows: in which cases and in how many cases does the GP's treatment strategy change as a result of the GP utilizing a physiotherapist's expertise (by means of a [one-time] consultation) to obtain 
additional diagnostic information (based on the physiotherapist's diagnoses) and to determine the indication for physiotherapy?

Subsequently it is important to determine whether the product meets the needs and expectations of both professions, how physiotherapist's consultations affect the outcome of patient treatment, and what conditions allow the process of consultation to be easily implemented in daily work situations.

To the best of our knowledge, no comparable research has been conducted on the outcome of physiotherapist's consultation in general practice. ${ }^{27.91}$ Therefore, it is prudent to evaluate in a pilot study whether or not a one-time physiotherapist's consultation in general practice is feasible, before starting the main study. Subsequently, the effects of a one-time physiotherapist's consultation were evaluated in an observational study with a follow up of all patients being referred for physiotherapy treatment following the consultation.

The following research questions are being examined in this thesis:

- How can the process of physiotherapy practice be defined and what answers are provided by the research literature to the question of the effectiveness of physiotherapy interventions (Chapter 2)?

- What is the impact of the various consultation models used by GPs and medical specialists consultants in the Dutch health care system on the proces of care and on patient outcomes (Chapter 3)?

- What is the feasibility of the proposed procedure for a one-time physiotherapist's consultation by written communication in general practice (Chapter 4)?

- What is the intra- and interobserver reliability of measurements to assess impairments and disabilities (Chapter 5)?

- What are the responses from GPs to at one-time physiotherapist's consultation in terms of (1) their opinion on the process and outcome and (2) the effect on their management decisions (Chapter 7)?

- What are the effects of a one-time physiotherapist's consultation on (1) the utilization of physiotherapy services, (2) functional outcomes and (3) the number of sessions per physiotherapy treatment episode. Also the question is addressed as to how functionalstatus- and health-status-related characteristics of patients referred for physiotherapy treatment, differ from those patients who, after a one-time physiotherapist's consultation, were treated by the GPs themselves (Chapter 8 ).

- To what extent are physiotherapist and practice setting characteristics determinants of the number of sessions per physiotherapy treatment episode (Chapter 9)? 


\section{Relevance of the Study}

The thesis as a whole may offer insight at a number of levels. Firstly, at the level of the patient: It is not currently possible for the referrer to have an overview of all of the options offered by physiotherapy. In addition, current health care policies are increasingly focused on the needs and demands of the patient, and require appropriate individuallytailored treatment programs. ${ }^{3.9,34}$ This thesis suggests that these problems could be partially avoided if physiotherapists and GPs, with mutual respect for the expertise of the other, worked together more closely. By improving the methods of cooperation and communication between GPs and physiotherapists, decision making by the GP could be supported in a qualitative sense.

Secondly, at the level of the professions: The results of this thesis give insight into the desirability of refresher- and follow-up courses for physiotherapists in the areas of consultation, communication between GPs and physiotherapists, essential exira training with regard to defined patient groups, and indications for physiotherapy. Through develop= ment of these areas, methodical work practices by physiotherapists will be stimulated and the potential for professional (physiotherapeutic) evaluation created.

Thirdly, at the level of policy: The results may provide insight for policy makers into the desirability of the implementation of (a one-time) physiotherapist's consultation. Such consultation would provide the GP with the opportunity to consult the physiotherapist without this necessarily leading to treatment. It is suggested that (a one-time) physiotherapist's consultation may make referral policy more rational and efficient.

\section{Scope of the Thesis}

The thesis is divided into four sections. Each section includes the following papers:

\section{Part 1: Introduction}

After an introduction to the study in Chapter 2 both the differences between medical and physiotherapist's diagnoses and the complementary nature of these disciplines are presented, and is a systematic approach to identify relevant information for determining the appropriate indications for physiotherapy established. A systematic approach of the process of physiotherapy practice is a prerequisite for quality improvement in patient care activities and for the development of meaningful outcome research. In Chapter 3 the research literature is reviewed documenting both the consultation models utilized in the Dutch health care system and effects on the process and outcome of care between GPs and medical specialists/consultants utilized in the Dutch health care system and the effects on the process and outcome of care. 


\section{Part II: Preliminary studies, research questions, and study design}

Chapter 4 contains the preliminary results of a feasibility study of a one-time physiotherapist's consultation in general practice. The results of the study on the intraobserver and interobserver reliability of assessments of impairments and disabilities using standard forms are presented in Chapter 5. The objectives, research questions and design of the observational study is described in detail in Chapter 6. Furthermore "a description is given of the selection procedure and representation of the participants.

\section{Part III: Results}

Chapter 7 focuses on the results of a one-time physiotherapist's consultation from the perspective of the GPs, such as their frequency of use, opinion of the outcome and its impact on their management decisions after the consultation. In Chapter 8 the results on utilization of physiotherapy services, the outcome of physiotherapy treatment after the consultation and the capability of physiotherapisis to predict that outcome are described. Furthermore, in Chapter 9 the determinants of the total number of sessions per treatment episode related to the recently changed remuneration system are explored.

\section{Part IV: Summary and General Discussion}

In the concluding section of the thesis (Chapter 10), the main findings of the thesis are summarized and briefly discussed with respect to future directions. Several methodological limitations and ethical topics are also discussed, and the implications of this thesis with respect to general practice, current health care reform and future research are considered. Finally, guiding principles and recommendations for implementing a one-time physiotherapist's consultation in general practice are proposed. The thesis will be concluded with a summary, both in English and in Dutch.

Chapters 1 to 9 of this thesis have been written as separate articles and have been published, accepted or submitted for publication in national and/or international scientific journals (see List of publications and presentations as a result of the thesis). Although there is some overlap between the chapters, in which the background and the design of the study is repeated, the format of this publication allows each chapter to be read as a separate paper.

\section{References}

1. Kwaliteit van zorg. Verhandelingen van de Tweede Kamer, vergaderjaar 1990-1991, 22 113, nrs. 1-2.

2. Kwaliteit in beeld. Special Kwaliteitsconferentie en Leidschendamafspraken. 1995-2000. Zoetermeer: Gezamenlijke sitgave van de NRV en de Geneeskundige Hoofdinspectie, 5e jaargang, nr. 3, blz.3-6, 1995.

3. Rijksinstituut voor Volksgezondheid en Milieu (RIVM). Volksgezondheid Toekomst Verkenning 1997. Effecten van zorg. RIVM Bilthoven; Elsevier/De Tijdstroom, 1997. 
4. Landelijke Huisartsen Vereniging. Het basistakenpakket van de huisarts. Utrecht: LHV Vademecum, 1987.

5. American Board of Internal Medicine. A statement on the generalist physician from the American Boards of family practice and internal medicine. JAMA. 1994;271(4):315-16.

6. Joint Working Party of the Welsh Council of the Royal College of General Practitioners and the Welsh General Medical Services Committee. Patient care and the general practitioner. BMJ. 1994;309:1144-47.

7. Ministerie van Welzijn. Volksgezondheid en Cultuur. Notitie Ontwikkeling Fysiotherapeutische Hulpverlening. Rijswijk, 1989.

8. Groenewegen PP, Hingstman $L$, Dekkeĩ J. Gebruik en beschikbaarheid van fysiotherapeutische zorg in. de tockomst. Ned Tijdschr Fysiother. 1990;100:84-91.

9. NRV. Nationale Raad voor de Volksgezondheid. Naar een meer vraaggerichte zorg. Zoetermeer: NRV, 1998.

10. Kerssens JJ, Curfs EChr, Groenewegen PP. Fysiotherapie in de Nederlandse gezondheidszorg, de. hulpverleners huisarts en fysiotherapeut. Utrecht: Nivel, 1986.

11. Kerssens JJ, Groenewegen PP. Referrals to physiotherapy: The relation between the number of referrals, the indication for referral and the inclination to refer. Social Science \& Medicine. 1990;30:797-804.

12. Kerssens JJ, Curfs EChr. Exiramurale fysiotherapie [Dissertatie]. Utrecht: Nivel, 1993.

13. Uunk W, Dekker J, Groenewegen P. Verwijzingen van huisartsen naar fysiotherapeuten: morbiditeitsspecifieke verwijspercentages. Deelproject Huisarts en fysiotherapeutische zorg: Basisgegevens uit de Nationale Studie van Ziekten en Verrichtingen in de Huisartsenpraktijk. Utrecht: Nivel, 1991.

14. Lamberts H. In het huis van de huisarts. Verslag van het Transitieproject. Lelystad: Meditekst, 1991.

15. Jaarboek Ziekenhuizen. Utrecht:SIG/Informatiecentrum voor de gezondheidszorg, 1992.

16. Grundmeijer HGLM, Brouwer HJ. De betekenis van fysiotherapie bij aandoeningen van het bewegingsapparaat. Huisarts Wet. 1988;31:44-50.

17. Velden J van der, Bakker DH de, Claessens AAMC, Schellevis FG. Nationale studie naar ziekten en verrichtingen in de huisartsenpraktijk. Basisrapport: Morbiditeit in de huisartsenpraktijk. Utrecht: Nivel, 1991.

18. Centraal Bureau voor de Statistiek (CBS). Statistisch jaarboek 1993. s-Gravenhage: Staatsuitgeverij, 1994.

19. Heugten CM, Sluijs EM, Dekker J. Programmering van onderzoek naar doelmatigheid van paramedische zorg: een verkennende studie. Utrecht: Nivel, 1995.

20. Centraal Bureau voor de Statistick (CBS). Statistisch jaarboek 1998. Voorburg; Heerlen: CBS, 1999.

21. Stanton PE, Fox FK, Francois KM, Hoover DH, Spilecki GM. Assessment of resident physicians? knowledge of physical therapy. Physical Therapy. 1985;65:27-30.

22. Uili RM, Shepard K, Savinar E. Physician knowledge and utilization of physical therapy procedures. Physical Therapy. 1984;64:1623-30.

23. Anderson J, Campbell SK. Correlates of physician utilization of physical therapy. International Journal of Technology Assessment in Health Care 1992;8(1):10-19.

24. Ritchey FJ, Pinkston D, Goldbaum JE, Heerten ME. Perceptual correlates of physician referral to physical therapists: Implications for role expansion. Social Science \& Medicine. 1989;28:69-80.

25. Hulme JB, Wackernagel B, Lewis JW. Communication between physicians and physical therapists. Physical Therapy. 1988:68:26-31.

26. Rijdt van der $T$, Lubbers, $M$, Kolker $L$. Het verbeteren van samenwerking. Eindverslag van het project Samenwerking huisarts en fysiotherapeut. Utrecht: Stichting O\&O, 1990.

27. Hendriks HJM, Wagner C, Brandsma JW, Dekker J, Wams HWA, Oostendorp RAB. Consultatief fysiotherapeutisch onderzoek (C.FO) in de eerste lijn. Introduktie van het CFO-project en informatie uit de literatiur. Ned Tijdschr Fysiother. 1992;102:176-183.

28. Hendriks HJM, Brandsma JW, Wagner C, Dekker J. Het Consultatief Fysiotherapeutisch Onderzoek (CFO) in de eerste lijn. Eindverslag Fase 1. Amersfoort: SWSF, 1992.

29. Heuvel $C$ van den. De kwalitent van de werkrelatie met fysiotherapeuten. De Huisarts, 1991:10:22-24.

30. Beckerman H, Bouter L. Effectiviteit van fysiotherapie: een literatuur onderzoek. Maastricht: Rijksuniversiteit Limburg, 1991.

31. Post D, Zanten van A. Hoe nodig is fysiotherapie? Medisch Contact 1992;19:590-93.

32. Landelijke: Huisartsenvereniging (LHV), Jaarverslag 1995. Utrecht: LHV, 1996. 
33. Landelijke Huisartsenvereniging (LHV). Jaarverslag 1996. Utrecht: LHV, 1997.

34. Hendriks HJM. Consultatie van de fysiotherapeut. Een middel voor een betere samenwerking tussen huisartsen en fysiotherapeuten. Jaarboek Fysiotherapie 1993. Houten: Bohn, Stafleu van Loghum, 1993.

35. Nederlandse Patiēnten/Consumenten Federatie (NP/CF) en Raad voor de Volksgezondheid en Zorg (RVZ). Keuzevrijheid en keuzemogelijkheden voor patiënten in het zorgstelsel. Utrecht; Zoetermeer: NP/CF en RVZ, 1997.

36. Ziekenfondsraad. Financiëel Jaarverslag 1994. Amstelveen: Ziekenfondsraad, 1995.

37. Wet op de Paramedische Beroepen: Wet van $21 \mathrm{mrn} 1963$ stb.113, laatstelijk gewijzigd bij de Wet van 23 juni 1976, stb.377.

38. Ministerie van Welzijn, Volksgezondheid en Cultuur (WVC). De Wet BIG; hoofdlijnen van de Wet Beroepen in de Individuele Gezondheidszorg. Rijswijk: Ministerie van WVC, 1994.

39. Fysiotherapeutenbesluit. In: Staatsblad van het Koninkrijk der Nederlanden, 1977 no.432: Besluit van 1 juli 1977 tot vaststelling van nieuwe regelen inzake het beroep van fysiotherapeut.

40. NRV, Nationale Raad voor de Volkgezondheid. Nota indicatiestelling in de gezondheidszorg; nota inzake de indicatiestelling in de gezondheidszorg en de maatschappelijke dienstverlening. Publikatie 4/90. Zoetermeer: NRV, 1990.

41. Ziekenfondswet: Tekst van de wet van 15 okt. 1964, houdende regelen met betrekking tot de geneeskundige verzorging door middel van Ziekenfondsverzekering, stb.392.

42. Bernards ATM. Schets voor een theoretisch kader fysiotherapie [Lustrum-symposium]. Amersfoort: SWSF, 1989.

43. Wong WP, Galley P, Sheehan M. Changes in medical referrals to an outpatient physiotherapy department. Australian Physiotherapy. 1994;40(1):9-14.

44. Van Dale: Groot woordenboek der Nederlandse taal. Van Dale Lexicografie, 1992.

45. Melker RA de. Samenwerking tussen huisarts en fysiotherapeut binnen de eerstelijns gezondheidszorg. Ned Tijdschr Fysiother. 1981:91:254-60.

46. Melker RA de. Samenwerking tussen de eerste- en tweedelijn in de gezondheidszorg. In: Peters JH [red.]. Management in de gezondheidszorg. Utrecht/Antwerpen: Bohn, Scheltema \& Holkema, 1986.

47. NRV, Nationale Raad voor de Volksgezondheid. Discussienota substitutie in de gezondheidszorg. Zoetermeer, 1989.

48. Ministerie van Welzijn, Volksgezondheid en Cultuur. Over de ontwikkelingen van gezondheidsbeleid: feiten, beschouwingen en beleidsvoornemens (Nota-2000). Rijswijk, 1986.

49. Commissie modernisering curatieve zorg, (Biesheuvel BW et al.). Gedeelde zorg: betere zorg [rapport]. Roosendaal: Koninklijke Van Poll, 1994.

50. Kersten TJMMT. De invloed van de huisarts op de specialist. Een theoretische analyse getoetst aan de opvattingen van huisartsen. Tijdschr Soc Gezondheidsz. 1992;70:171-79.

51. Uunk WJG, Groenewegen PP, Dekker J. Verwijzingen van huisartsen naar fysiotherapeuten: een verklaring en analyse van verschillen tussen huisartsen. Mens en Maatschappij. 1992; 67(4):389-411.

52. Akpala CO, Curran AP, Simpson J. Physiotherapy in general practice: patterns of utilization. Public Health. 1988:102:263-68.

53. Klaveren van AAJ, Oostendorp RAB, Ravensberg van CD, Elvers JWH, Hendriks HJM. Basisgegevens van het Fysiotherapie Ontwikkelings Netwerk. Een inventarisatie van het fysio-therapeutisch handelen in de eerste lijn m.b.v. het Basis Registratieformulier Fysiotherapie. Amersfoort: NPi, 1996.

54. Valk R van der, Dekker J, Boschman M. Basisgegevens extramurale fysiotherapie 1989-1992. Gegevens. uit het project "beleidsgericht evaluatie- en effectonderzoek fysiotherapie (BEEF)". Utrecht: Nivel, 1995.

55. Heerkens YF, Brandsma JW, Bernards ATM, Hendriks HJM, Lakerveld-Heyl K, Ravensberg CD, Wams: HWA, Oostendorp RAB, Helders PJM. Zin en onzin van het gebruik van de ICIDH. Fysiopraxis. 1993;18:18-21,

56. Mischner-van Ravensberg CD, Paauw HJM, Gestel JLM. De fysiotherapeutische werkdiagnose in relatie tot de medische diagnose. Ned Tijdschr Fysiother. 1988;5:104-07.

57. Rose S. Physical therapy diagnosis: role and function. Physical Therapy. 1989:69:535-37.

58. Sahrmann SA. Diagnosis and classification by the physical therapist - a prerequisite: for treatment: a special communication. Physical Therapy 1988;68(11):1703-06.

59. Baar van ME, Dekker. J, Kool van Langenberghe HV. Medisch specialist en fysiotherapeut. Informatieoverdracht naar de eerste lijn. Medisch Contact 1993;48(27/28):85 I-853. 
60. Bertels M, Brummeler L ten, Dijkum C van, Giebels R, Mannen J van der. Tijd voor kwaliteit: evaluatieonderzoek fysiotherapie in. gezondheidscentra in Amsterdam. Amsterdam: SISWO, 1985.

61. NRV, Nationale Raad voor de Volksgezondheid. Discussienota Begrippenkader kwaliteit beroepsuitoefening. Zoetermeer, 1986.

62. NRV, Nationale Raad voor de Volkgezondheid. Discussienota Aigemeen begrippenkader kwaliteitsbevordering . Zoetermeer, 1990.

63. Have JJIM ten, Kolker L. Consultatievormen tussen huisarts en specialist. Utrecht: Stichting O\&O, 1990.

64. McKegney FP, Beckhardı RM. Evaluative research in consultation-liaison psychiatry. General Hospital Psychiatry. 1982;4:197-218.

65. Avant RF. Psychiatric consultation and referral. Medical Clinics of North America. 1988;72(4):929-35.

66. Pop P. Consultatie eerste-tweede lijn. Drie jaar Diagnostisch Centrum Maastricht. Medisch Contact. 1982;37:1019-23.

67. McPhee SJ, Lo B, Saika Y, Meltzer R. How good is communication between primary eare physicians and subspecialty consultants? Archives of internal Medicine. $1984 ; 144: 1265-68$.

68. Haaften KL van, Schuringa-de Boer WJ. Analyse van vijf samenwerkingssituaties. In: Greve WB de [red.]. Samenwerking ziekenhuis en eerstelijn; pag. 7-35. Alphen aan den Rijn: Stafleu, 1983. Serie: Leiding \& organisatie in de gezondheidszorg: een reeks kwartaalschriften.

69. Coulter A, Noone A, Goldacre M. General practitioners referrals to specialist outpatient clinics! Why general practitioners refer patients to specialist outpatient clinics. BMJ. 1989;299:304-08.

70. Atis. Werken aan samenwerken: het initiêren van multidisciplinaire samenwerking in de eerstelijnszorg. Bunnik, 1988.

71. Jacobs HM, Melker RA de, Touw-Otten FWMM. Samenwerking tussen huisartsen en specialisten (1). Medisch Contact. 1983;38:1599-1601.

72. Jacobs HM, Melker RA de, Touw-Otten FWMM. De taakafbakening van hel professionele handelen tussen huisartsen en specialisten. In: van Es et al. [red.]. Het Medisch Jaar 1984; pag: 50-58. Utrecht/Antwerpen: Bohn, Scheltema \& Holkema, 1985.

73. Suijlekom-Smit LWA van, Crone-Kraaijeveld E. Het zieke kind, een zorg voor huisarts en kinderarys [Dissertatie]. Rotterdam: Erasmus Universiteit Rotterdam, 1994.

74. Franks P, Clancy CM, Nutting PA. Gatekeeping revisited-protecting patients from overtreatment. N Engl J Med. 1992;327(6):424.29.

75. Beek M, Eijk J van, Rutten G. Verschuivingen van eerste naar tweede lijn? Opvattingen van huisartsen en specialisten. Medisch Contact. 1985;40:299-302.

76. Pop P, Beusmans GHMI, Knottnerus JA. Een diagnostisch centrum voor Maastricht. Versterking van de eerste lijn en samenwerking huisarts-specialist. Medisch Contact. 1987;42:845-48.

77. Pop P, Kerkhof PD. Diagnostisch Centrum Mastricht: Eindevaluatie van een experiment. Medisch Contact. 1984;39:749-52.

78. Came S. A problem halved? Journal of the Royal College of General Practitioners. 1982:32:10-31.

79. Braak E, Lange L de, Cleton-van de Dikkenberg E. Een geriatrisch consultatiepunt voor huisartsen. Medisch Contact. 1989;44:717-19.

80. Brouwer W. Het eenmalig geriatrisch consult. Huisarts Wet. 1983;26:140-44.

81. Grinten $\mathbf{R}$ van der. Communicatic huisarts-internist. Vier jaar ervaring met consultatie in het gezondheidscentrum Withuis. Medisch Contact. 1981;36:777-81.

82. Hall EV van, Gill K, Trimbos JB. Gynaecologische consultaties in de huisartspraktijk. Medisch Contact. 1987;42:105-06.

83. Smit DJ de. Consultatie huisarts-specialist. Experiment bij kinderen met luchtwegproblemen. Medisch Contact. 1987:42:849-52.

84. Smit DJ de. Ervaringen met consultatiebijeenkomsten. Medisch Contact. 1990;47:1413-15.

85. Vierhout W. Gezamenlijk consult huisants-specialist. Medisch Contact. 1987;42:106-09.

86. Vierhout WPM. Het gezamenlijk consult van huisans en specialist in de eerste lijñ. Een nieuwe werkwijze bij klachten van het bewegingsapparaat [Dissertatie]. Maastricht: Rijksuniversiteil Limburg, 1994.

87. Wersch-Spek MCM van der. Ervaringen met de consultatiefunctie van het verpleeghuis in het verzorgingshuis. Medisch Contact. 1990;45:385-87.

88. Von Korff M, Katon W, Lin EHB, Wagner EH. Evaluation of psychiatric consultation-liaison in primary care settings. Gen Hos Psychiatry 1987;9:102-110. 
89. Nederlands Huisartsen Genootschap. De verwijsbrief naar de Tweede Lijn - standaard 001. Huisarts Wet. 1989;32:102-05

90. Koninklijk Nederlands Genootschap voor Fysiotherapie. Richtlijnen voor de fysiotherapeutische verslaglegging. Amersfoon; CBF, 1993.

91. Hendriks HJM, van der Zee J, de Bie RA. Consultation between General Practitioners and medical consultants in the Dutch health care system. What can we learn from the literature? (submitted)

\section{Note}

1. Estimate of referral figure for physiotherapy is based on Kerssens \& Curfs ${ }^{12}$ corrected for the increase of physiotherapy services (based on health statistics of the CBS) between 1985 and $1994 .^{18.20}$ 


\title{
The Diagnostic Process and Indication for Physiotherapy A Prerequisite for Treatment and Outcome Evaluation
}

\begin{abstract}
The need for the profession of physiotherapy to illustrate its value to the external world is becoming more obvious each year. Those who pay for physiotherapy services would like to limit the number of sessions and the length of the treatment episode of physiotherapy care. It is therefore incumbent on the profession to design a conceptual framework for the physiotherapy process that can be used to study the efficacy, effectiveness and efficiency of physiotherapy by employing appropriate clinical research techniques. The result of this research can contribute to the development of treatment guidelines to produce optimal patient outcomes.

The purpose of this paper is twofold: (1) to provide insight into the similarities and differences between medical and physiotherapy diagnoses; and (2) to provide a basis by which the physiotherapist's diagnosis helps to determine the indication for physiotherapy, the strategy of physiotherapeutic care, and the outcome prognosis.

A systematic multilevel system approach to the process of physiotherapy practice is a prerequisite for the improvement of the quality of patient care, and the design of meaningful randomized clinical trials.
\end{abstract}

\section{Introduction}

In the Netherlands, more than 2 million out of 15 million people are referred arnually for physiotherapy. ${ }^{1.2}$ Only a small number of these patients have reported that physiotherapy was not beneficial..$^{3 \cdot 7}$ Despite these high rates of patient satisfaction, ${ }^{3 \cdot 7}$ the physiotherapy profession is being placed under great pressure from the society to justify its impact on public expenditure in these times of financial pressure. There is a growing need to justify the rationale behind physiotherapy treatments, and to provide evidence that physiotherapy has clinically relevant effects on the course and progress of the patient's functional status. 
The efficacy, effectiveness and efficiency of physiotherapy practice need to be determined. The knowledge needed to attain this goal can only be achieved through research to provide a theoretical perspective to physiotherapy and evidence-based practice.

In the last decade, the effect of various physiotherapeutic interventions has been investigated. Many of these studies did not show significant beneficial effects. ${ }^{8-21}$ More recently, physiotherapy interventions have been explored by research physiotherapists, whose work has led to a clearer understanding of the process of physiotherapy practice and resulted in changes in clinical reasoning and clinical practice. ${ }^{13.18,22-27}$ To best assess the efficacy and the effectiveness of physiotherapy and justify patient treatment, insight into the diagnostic and treatment process of physiotherapy practice is needed before meaningful research can be undertaken. Identifying relevant patient information (health status) and intervention characteristics is a prerequisite for guiding treatment and determining outcome. It also provides a foundation for appropriately designed randomized controlled clinical trials (RCTs) to evaluate treatment outcomes.

\section{Problems in outcome research}

The RCT has gained prominence in health care research due to its potential to provide a valid assessment (as a "gold standard") of the efficacy of an intervention. ${ }^{12,13,28-31}$ While current knowledge of the efficacy and effectiveness of physiotherapy practice is far from ideal, it is highly unlikely that any aspect of physiotherapy is so unique that it cannot be investigated and evaluated using the wide range of techniques available from basic, social and clinical science. ${ }^{13,25,32-34}$ However, only randomized controlled group studies provide results that can be generalized; these are essential for treatment evaluation. ${ }^{28.30}$

There are already considerable numbers of published RCTs in the field of physiotherapy. Conclusions from the research literature about evidence-based practice indicate a growing need for properly conducted systematic reviews to summarize the results of published evidence and the implications for day-to-day practice. . $^{9,1,18,21,25,35-38}$ It is also important to discern those clinical trials with poor methodology and poor content (not reflecting the usual provision of physiotherapy) that may yield misleading results. ${ }^{13,21,25.31-37}$

The evaluation of RCTs by means of explicit methodological criteria (see for example de $\mathrm{Bie}^{36}$ or others ${ }^{39-42}$ ) derived from a large number of trials produces a kaleidoscopic picture of the quality of RCTs. ${ }^{941,25,38,40,43-57}$ This is not a problem exclusive to physiotherapy.$^{8.58-60}$ The methodological quality of RCTs in the domain of physiotherapy ranges from good to bad. From reviews of the literature, meta-analyses, and systematic reviews, the most important conclusion to be drawn is that no general conclusion may be drawn concerning the efficacy of physiotherapy. ${ }^{9-11,13,18,21,25,32-34.37}$ The various RCTs often cannot be compared due to the lack of meaningful demarcation in categories of patients who are prognostically homogenous with respect to the intervention at issue. Frequently, 'pars-prototo' conclusions are drawn. For example, if a certain type of electro- or ultrasound therapy (as an adjunct) does not result in a significant difference in outcome between the experimental and the control group in the case of medical defined shoulder disorders, it does not follow that physiotherapy is ineffective in all patients with shoulder 
disorders. ${ }^{50,61,62}$ Rather, it may only be concluded that this type of electro- or ultrasound therapy was ineffective in the homogenous medically defined group that might be heterogeneous in terms of the nature and extent of the underlying pathology, impairments, limitations in activities, restriction in participation and perceived health problems.

In addition to the evaluation of the methodology, the evaluation of the content of the RCTs exposes a number of fundamental problems. In many RCTs, patients are included on the basis of demographic and medical criteria that are often not related to the focus of physiotherapy. ${ }^{13,20-22,25-27,32,33,37}$ Although the medical information by itself provides important information, it is often an inadequate starting point for physiotherapy treatment. ${ }^{17,18,22.25,63-77}$ Treatment goals are often aimed at the resioration and preservation of a patient's functional status, thereby contributing to the patient's quality of life. ${ }^{19,20,68,78 \text { - }}$ ${ }^{81}$ Only a few RCTs take the physiotherapist's diagnosis into account to provide insight into the extent to which the functional problem (and treatment goals) may be influenced by physiotherapy (see for example van Baar et al, ${ }^{82}$ Oerlemans et a! ${ }^{83}$ and Kwakkel et $\left.\mathrm{al}^{84}\right)$. Without clear indications for physiotherapy, defined treatment objectives and related process and outcome measures, it can be assumed of many RCTs that little significant difference will be found between the experimental and the control group(s).

The extent to which physiotherapy practice is currently based on evidence is small. Although the conclusions about its efficacy are often disappointing, they are also limited and should be interpreted cautiously due to several methodological flaws. These flaws may include: inadequate methodology that does not reflect the way physiotherapists work; inappropriate patient selection and outcome variables; insufficient inside knowledge among researchers about physiotherapy; rigid protocols within which the individual therapeutic "dose-response" relationship is not sufficiently taken into account; and lack of control for both intra-individual (e.g. lifestyle and behaviour changes, psychosocial attributes and coping) and extra-individual (e.g. medical care and rehabiliation, external supports, physical and social environment) factors that correlate for incidence and outcome. . $^{13,20,25,64,65,75,80,85-90}$

In conclusion, physiotherapy research is necessarily complex because it involves assessment of multiple human systemic and functional levels (e.g. cellular tissue, organic, systemic, or mental), operates against a baseline that is rarely stable (not all extra- and intra-individual factors are under the control of the physiotherapist). Physiotherapy is often provided as a "package", rather than a single, quantifiable intervention. Physiotherapy intervention can be characterised as individually tailored care; the patient is individually examined and evaluated and given a specific intervention with different components, techniques or modalities that are, from a particular physiotherapist's point of view, most appropriate to that patient's particular problem and needs. This may include advice on home-exercises, the cause of the pain and pain relief, its prevention, and relevant aspects of daily living. While separating the various components of a physiotherapy intervention to assess its most beneficial component is methodologically complex, this does not preclude the necessity of such valid research of its clinical relevance..$^{13.25 .32-34}$ 
There is no doubt that outcome research is needed to shed some light on the efficacy and effectiveness of physiotherapy practice; there is a growing need for greater clarity to legitimize physiotherapy's role and position in the health care system. Outcome research and understanding outcomes mean nothing more than understanding physiotherapy practice. Therefore, a systematic multilevel approach to the process of physiotherapy diagnosis and treatment is a prerequisite for identifying relevant information to guide treatment, and to design meaningful RCTs.

\section{Understanding physiotherapy practice}

The physiotherapy profession is relatively new to research, but current clinical, political and educational trends have brought a great impetus for research. The lack of knowledge and consensus about physiotherapy practice implies that, in many cases, the RCT is often a less suitable option for research than other models. A prematurely conducted RCT will not contribute to an understanding of the process of physiotherapy practice and is often not a productive allocation of scarce resources. For a thorough understanding of the descriptors of physiotherapy practice (practice patterns, patient profiles), case studies, fundamental research and observational studies or surveys are also needed. ${ }^{91.92}$ These types of studies are necessary first to gain insight into the way physiotherapists actually work, and second, to gain insight into the kind of information needed to guide treatment. With increased insight, new treatment theories can be developed on the basis of empirical data related to effective and efficient treatment practice. Furthermore, research should be focused on predictors and indicators of treatment outcome, with more attention to outcome measures focused on (1) the goals of physiotherapy treatment, (2) the effects of treatment on the patient's functional status, and (3) the effects on the patient's quality of life. If the process of physiotherapy practice is clarified, it will be possible to investigate objectively the efficacy and effectiveness of physiotherapy by designing studies that satisfy both methodological as well as content criteria. Thus, progression from descriptive studies to experimental research is suggested to be more appropriate. Studies based on homogenous patient groups, an adequate description of a (theory-based) intervention, and valid/relevant outcome variables will give physiotherapy a fair chance to prove its efficacy and effectiveness. It is a challenge to design controlled trials incorporating methodology that accurately reflects contemporary physiotherapy practice, mirroring the way physiotherapists actually work. Improved research and treatment design will ultimately promote the scientific and professional development of physiotherapy.

The purpose of this paper is twofold: (1) to provide insight into the similarities and differences between medical and physiotherapy diagnoses; and (2) to provide a basis by which the physiotherapist's diagnosis helps determine the indications for physiotherapy, the strategy of physiotherapeutic care, and the outcome prognosis. 


\section{Table 1. The different phases of the process of physiotherapy practice}

- Examining the referral data

- History taking

- Conducting a physical examination and evaluation of the patient's (functional) status

- Formulating the physiotherapist's diagnosis, and determining if physiotherapy is indicated

- Formulating the treatment plan

- Providing the treatment

- Evaluating the (changes in) a patient's (functional) status and one's own course of action

- Concluding the treatment period and reporting to the referring discipline

\section{The Process of Physiotherapy Practice}

In the physiotherapy profession there is a growing emphasis on clinical reasoning. Barrows and Feltovich ${ }^{93}$ defined it as: "A problem-solving approach designed to adapt to the need to obtain more information to resolve an initially ambiguous diagnostic situation and the need to work with a progressive unfolding of information over time". James ${ }^{94}$ mentioned four aspects which are worth emphasizing for this complex definition. First, that clinical reasoning is fundamentally a problem-solving process whereby the outcome should be the solution of the patient's problem. Second, patient information is acquired and, indeed, is vital to the process. The third aspect relates to the ambiguity inherent in the situation. Patient information contributes to both the ambiguity and to the clarification of the situation. Such information could be described as inherently 'noisy' since it may contain redundant aspects, which, if pursued, would divert from key aspects. Finally, it should be noted that clinical reasoning is related to time since it gradually unfolds. It is important that the classification of the patient's problem will support the prescription of a suitable evidence, research or at least theory based intervention to reverse or alleviate the dysfunction. Clinical reasoning requires a systematic process of diagnosis and concurrent evaluation during the process of treatment for the identification of a patient's problem and response to treatment.

A systematic process of diagnosis and treatment is characterized by a consistent, wellconsidered performance designed to achieve an established objective. A systematic process of physiotherapy practice has five characteristics: (1) it has a purpose; (2) its course is professional; (3) it is cyclic by nature; (4) it takes place consciously; and (5) it aims at efficiency. A systematic approach is a necessary condition for making explicit the considerations, arguments, and activities underlying certain decisions. On the one hand, it is essential for self-reflection and, on the other hand, it offers the opportunity for external testing. Methodical conduct of the process of physiotherapy practice means conduct agreed and defined by the professional body in the national guideline for documentation (Table 1 and Figure 1). ${ }^{70.71 .95 .96}$

Figure 1 outlines the process of diagnosis, indication for physiotherapy and treatment. The upper portion of Figure 1 refers to the diagnostic process and the process by which the 
referring discipline determines an indication for physiotherapy treatment; the middle portion shows the physiotherapist's diagnostic process and the process of determining the indication for physiotherapy; the lower portion shows the physiotherapist's treatment process. It is important to note that the various phases are cyclic by nature, and that feedback takes place between the various phases. A decision is made, after each phase, whether to proceed or to return to an earlier phase.

\section{Indication setting}

Appropriately determining the indications for physiotherapy is important in order to provide individually tailored care, and to control health care costs. Indication setting is defined as "the determination of the kind of care required, and which discipline, expertise, and equipment are best suited to the needs of the patient". ${ }^{97.98}$ No explicit criteria are currently available for establishing an indication for physiotherapy. Accordingly, substantial differences exist among referring physicians on the indications for physiotherapy. ${ }^{90-106}$ This raises the question as to whether, in general, physicians are sufficiently equipped to establish the indications for physiotherapy. ${ }^{25.104 .105,107}$ If a referring physician is in doubt about the indications for physiotherapy or the treatment options available, it would make sense to refer for a one-time physiotherapist's consultation with a clearly defined consultation query about the indication for treatment, treatment goals and treatment options. ${ }^{67,104,107}$ When consulting a physiotherapist or referring a patient for treatment, it is important that the referring physician's request contains the reason for referral and medical findings/information as well as the recommendations for (the goals of) physiotherapy intervention. ${ }^{25,64,68,70,71}$

\section{Medical information}

The first information the physiotherapist receives about the patient are data provided by the referring physician. These data are sometimes brief and sometimes more extensive. According to the B.I.G. Act (Wet Beroepen in de Individuele Gezondheidszorg), ${ }^{108}$ the referral should contain at least the medical diagnosis, the referral diagnosis, and the referral data.

\section{Medical diagnosis}

The medical diagnosis may be a disease-diagnosis, such as rheumatoid arthritis, cerebrovascular accident, multiple sclerosis, Parkinson's disease, , hernia nuclei pulposi or tendon injury (classified according to the International Classification of Diseases and Related Health Problems (ICD-10). ${ }^{109}$ The diagnosis may also be a symptom-diagnosis, especially in cases where the GP or medical specialist cannot specify the disorder or disease. For example. dysfunction of the neck and back, headache. dizziness, or referred pain in the arm are symptom-diagnoses. Because disorders frequently cannot be classified under a defined diagnosis, a classification has been developed for primary care which offers the opportunity to code medical diagnosis as well as symptom-diagnoses (International Classification of Primary Care (ICPC). ${ }^{110}$ A large part of its "Musculoskeletal" (code L) 
section concerns disorders and/or symptom-diagnoses. Patient referrals, to physiotherapists by GPs, often contain such a symptom-diagnosis, whereas referrals made by medical specialists predominantly contain a disease-diagnosis. ${ }^{25.111}$

The physician's diagnostic process leads to the identification and wording of the diseaseor the symptom-diagnosis and to the indication for further action. This may imply that the GP' decides to treat the patient directly, to refer to a medical specialist, or to refer to a physiotherapist or to another allied health professional. For treatment by the GP in The Netherlands, an increasing number of national (evidence-based) clinical practice guidelines (NHG-standaarden) are available, a number of which concern the locomotor system (NHG-Standaarden ${ }^{12-127}$ ). By referring to al physiotherapisi, the referrer means in fact that the care required is physiotherapy: "my discipline, expertise, and equipment are for different reasons not the most appropriate for the needs of the patient".

Considerations of necessity, purposefulness, and effectiveness are increasingly present in the decisions made by the GP to refer to physiotherapy for treatment or (a one-time) consultation. For example, according to the national guidelines for general practitioners (primary care physicians) in the management of "acute low back pain" there is no "indication for physiotherapy" the first 6 weeks in an episode of low back pain ${ }^{117}$ because there is no scientific evidence that physiotherapy is beneficial in this firsi phase. ${ }^{128 \cdot 31}$ In approximately $75 \%$ of patients, symptoms will have ceased within 6 weeks without any intervention. In this case, a referral for physiotherapy treatment is inappropriate unless we are able to identify treatable predictors to prevent chronicity. ${ }^{132}$ If the usual course of recovery is delayed, the indication for physiotherapy treatment increases to prevent chronicity. ${ }^{104,105,117,128,132}$

\section{Referral diagnosis}

The physiotherapist takes note of the referral diagnosis. The referral diagnosis is not necessarily identical to the medical diagnosis. For example, a referral diagnosis could be "increased joint pain and stiffness in a patient with rheumatoid arthritis" or "rediced independence in transfers in a patient following a cerebrovascular accident." While the medical diagnosis is worded in medical terminology according to the International Classification of Diseases ${ }^{109}$ or ICPC ${ }^{110}$ the referral diagnosis is stated in terms that indicate the direction of the health problem. In the examples "increased joint pain and stiffness in a patient with rheumatoid arthritis" and "reduced independence in transfers in a patient following a cerebrovascular accident," the diagnosis is stated in terms that stress the problem of the patient.

For the physiotherapist, the conceptual framework of the International Classification of Impairments, Disabilities, and Handicaps (ICIDH) $)^{133}$ and Function/Structure, Activities and Participation (beta-2 draft ICIDH-2) ( $^{87}$ is instrumental in verbalizing health problems in terms of functions (impairments; e.g. pain and stiffness of joints), activities (limitation in elementary [e.g. walking] or complex activities of individuals in daily life [e.g. personal care]), and restriction in participation (e.g. reduction in participation due to, for example, problems in reaching or accessing buildings) ${ }^{63-66,77,87.133-135}$ 
Figure 1. The process of diagnosis, treatment and outcome evaluation

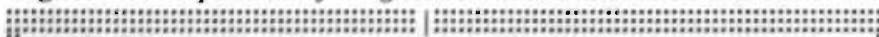

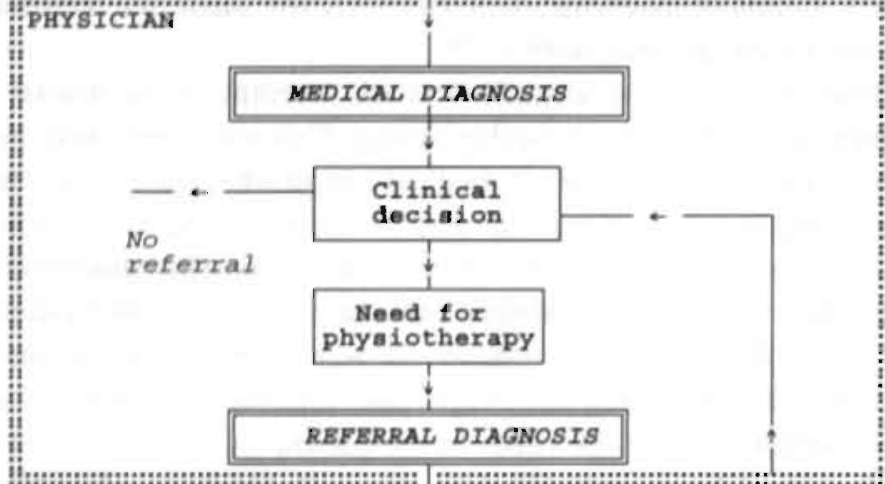

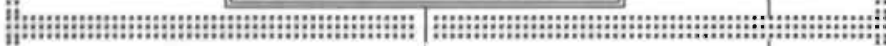

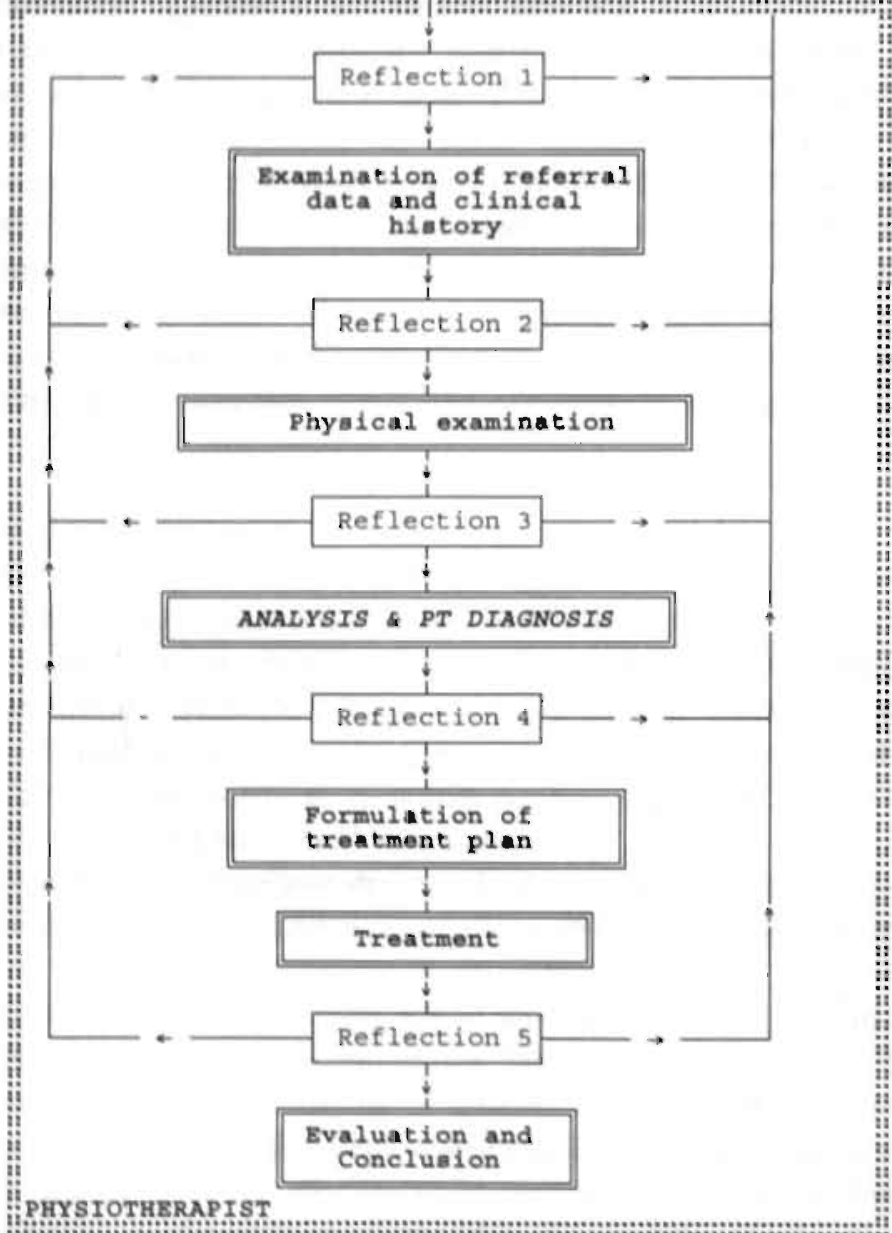

diagnostic process

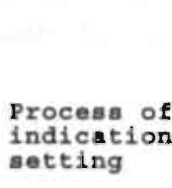




\section{Referral data}

Referral data provide context for the actual health problem with respect to previous diseases/disorders, earlier interventions, the duration of symptoms, and the patient's psychosocial functioning. In order to classify referral data, a Classification of Medical Terms for allied health professions ${ }^{136}$ has been developed.

Figure 2. A conceptual framework of health condition (disease) and disablement, and their interactions on different levels (e.g. impairments in function/structure, limitation in activities, and restriction in participation as described in the Beta-2 Draft (ICIDH-2), ${ }^{n}$ and quality of life

\begin{tabular}{|c|c|c|c|c|}
\hline \multirow[b]{2}{*}{$\begin{array}{c}\text { Function } \\
\text { (impairment in) }\end{array}$} & \multicolumn{2}{|c|}{$\begin{array}{l}\text { HEALTH CONDITION } \\
\text { (disorder/disease) } \\
+\end{array}$} & \multirow[t]{2}{*}{$\leftrightarrow$} & \multirow{3}{*}{$\begin{array}{c}\text { Perceived Quality of } \\
\text { Life } \\
\qquad\end{array}$} \\
\hline & $\begin{array}{c}\text { Activities } \\
\text { (limitation in) } \\
+\end{array}$ & $\begin{array}{c}\text { Participation } \\
\text { (restriction in) }\end{array}$ & & \\
\hline \multicolumn{3}{|c|}{$\begin{array}{l}\text { CONTEXTUAL FACTORS } \\
\text { (personal* and environmental/ factors) }\end{array}$} & $\leftrightarrow$ & \\
\hline
\end{tabular}

* Personal factors: e.g. gender, education, personality, coping styles, life habits, social background

* Environmental factors: e.g. products \& technology, natural environment \& human-made changes to environment, support \& relationships, attitudes, values \& beliefs, services, system \& policies

\section{Process of physiotherapist diagnosis}

Based on the medical diagnosis, the referral diagnosis, and the referral data, the physiotherapist gathers complementary information from the clinical history and by physical examination in order to gain insight into the health condition and perceived health problem. ${ }^{25,64,65,68,71.75 .85}$ The main objective of the diagnostic process is to obtain an impression of the pathway from disease to the nature and intensity of the health condition/ health problem, and the extent to which these may be acted upon. It is expected that this pathway progresses from pathology or disorder, to impairments (dysfunctions), to disabilities (restriction in elementary and/or complex activities), to restriction in (social) participation and to quality of life.$^{86.87} \mathrm{~A}$ similar model for conceptualizing the progression from disease to disability, participation problems and (perceived) quality of life has been introduced by Verbrugge and Jette ${ }^{86}$ and adapted and modified by the beta- 2 draft (ICIDH$2)^{87}$ (see Figure 2). This model characterizes factors affecting activities and participation as risk factors (e.g. predisposing characteristics), extra-individual factors, and intraindividual factors, important for an understanding of the meaning and process of disablement to clarify the indication for physiotherapy through improved decision making. Questions such as those reproduced in Table 2 need to be answered. 
Table 2. Main objective of the physiotherapeutic diagnostic examination

- Patient information

- Is physiotherapy indicated?

- Which physiotherapeutic treatment objectives seems to be the most appropriate for this patient?

- By which strategy can these objectives be achieved?

- Which physiotherapeutic procedures should be used?

- Who will be the physiotherapist that will treat the patient (e.g. a physiotherapist with a specialization in a specific problem area [i.e. chest physiotherapist] or treatment procedures [i.e. manual therapy])?

In order to focus on the health problem, the concepts of "impairments in function/ structure, limitations in activities, and restriction in participation" of the ICIDH-2 may be used (Table 3). ${ }^{25,6468,71,77,80,134,135}$ The classification of Function/structure consists of a number of categories which, in greater or lesser detail, are relevant to physiotherapy. The classification of Activities consists of primarily locomotor and body movement activities, which are of particular relevance to physiotherapy.

The latter classification, Participation, is more a scale by which individuals can be classified in levels of socio-economic functioning. Assessment of restriction in participation seems to be an important task for a physiotherapist, although both the perceived burden of the health problem and the effects of physiotherapy treatment may result in changes at the level of participation. ${ }^{18,22,25,68,85.134}$

Cott et al developed the "movement continuum theory of physical therapy" ${ }^{22}$ According to this theory, important aspects of the diagnostic process are: the prediction of the maximum achievable movement potential (MAMP) for the individual (depending on physical, social, psychological and environmental factors), the determination of the preferred movement capability (PMC) and the current movement capability (CMC), and the identification of potential causes of a discrepancy between PMC and CMC. It is important to stress that the ICIDH ${ }^{63.87,133}$ as such is only a classification, a set of terms useful to indicate some of the relevant data (including health problems at different functional levels) in the process of care. The ICIDH does not, in itself, provide a theory of physiotherapy to fill that gap, but is a very meaningful reference for communicating about the health problem, and for providing insight into the process and goals of physiotherapy.

\section{History-taking}

The following key steps (listed in Table 4) are used in history-taking.

Inventory the perceived symptoms and functional problems reported by the patient. An inventory of the patient's symptoms and health problems helps to identify the patient's limitations in the performance of activities, and in aspects of participation. Interpreting the patient's symptoms and health problems involves an analysis of: (a) whether impairments of function or limitations in the performance of activities are related; 
Health condition: an alteration or attribute of the health status of an individual that may lead to distress, interference with daily activities, or contact with health services; it may be a disease (acute or chronic), disorder, injury or trauma, or reflect other health-related states such as pregnancy, aging, stress, congenital anomaly, or genetic predisposition.

Function: the specific action of a tissue, organ, organ system, or other body structure that is present at birth or develops later, mainly as a result of maturation

Impairment: any loss or abnormality of a body part (i.e. structure) or body function (i.e. physiological function). The physiological functions include mental, functions. Examples include: reduced range of motion; reduced muscle function; divergent breathing movement; urinary stress incontinence; impairment of the mechanical properties of the skin

Activity: the concrete activity and/or behavior of a person, in a qualitative or quantitative sense, that emerges when an elementary (simple) activity or bundle of elementary activities or complex skills and behaviors are put into practice in the context of the physical, social, and cultural environment

Disability: any restriction or lack of ability to perform an activity in the manner or range considered normal for a person according to age, gender, and the physical and social-cultural environment. Examples include: difficulty rolling in bed, sitting down, or standing up: difficulty gripping, lifting, carrying, or picking up objects; difficulty washing or dressing oneself; difficulty performing tasks related to household, school, work, hobbies, and recreation

Participation: the interaction of impairments and disabilities and contextual factors, i.e. features of the social and physical environment, and personal factors. Examples include: personal maintenance, mobility, exchange of information, social relationships, occupation, economic life and civic and community life:

Participation restriction: a disadvantage, for a person with an impairment or disability, that is created, or worsened, by features of the contextual factors (the complete background to a person's life and living), i.e. environmental and personal factors

(b) if there is a relationship between impairments, limitations in activities and restriction in participation; and (c) whether there is a relationship between the symptoms, the health problem, and the disorder/disease. If relationships do exist, how can they be categorized? Up until now, these relationships have been found to be exceedingly variable: sometimes there is a causal connection, sometimes a non-causal connection. $20,64,75,77,80,81,89,90,134,135,137-143$

Determine the onset of the first complaint andlor symptom. Determining the onset of complaints helps to identify the duration of the current complaint episode, since this episode frequently indicates the complexity of the patient's health problem. It is important whether or not a specific moment in time, traumatic or otherwise, can be indicated as the onset of the present complaint episode. For example, report of "collision on August 23, 1999" identifies a specific time of onset, whereas a report of "around 3 months of persistent pain" is non-specific. 
Table 4. Key components in the process of history taking

- Inventory the perceived symptoms and health problems reported by the patient.

- Determine the onset of the first complaint and/or symptoms.

- Inventory the factors related to the onset of the complaints and health problems by means of an analysis of loads and load-tolerances.

- Inventory the course of the patient's symptoms and health problems.

- Inventory the objective signs, symptoms and health problems.

Various points of departure are used with respect to the time of onset: ${ }^{144-151}$ (a) the stages of physiological recovery of different types of tissues following an injury; (b) the natural course of the disorder over a period of time; and (c) the duration with respect to the potential for developing chronic pain and/or dysfunction syndromes. ${ }^{145-152}$

Inventory the factors related to the onset of the complaints and functional problems via an analysis of the loads and load-iolerance. An inventory of factors related to the onset of complaints and health problems helps to obtain an overview of the physical, physiological, psychological (mental) and social factors related to the current health problem.

Interpreting the extent to which the distinctive factors, often inter-related, are connected to the current heaith problem helps to determine whether or not referral to physiotherapy is appropriate. Such factors may be related to the load (burden) experienced by the patient, and to the load-tolerance (ability to adapt). Under normal circumstances, there is a balance between load and load-tolerance. In other words, individuals are aware of any physical, psychological or social burden, and learn strategies to adapt their lifestyle to these burdens. A disturbance of the balance between load and load-tolerance frequently occurs in several domains (physical, psychological [mental], social). Often it is not possible to pin point a disease/disorder or tissue damage as the basis of disturbance to the balance. Classic examples of such disturbance are nonspecific back pain and nonspecific neck pain. The term nonspecific means that the symptoms cannot be placed in a medical framework of disease/disorder or tissue damage, by means of a medical diagnosis.

The load-tolerance of tissues, organs, and organ systerns says something about the capacity to tolerate mechanical, chemical, and thermal stress. Hence, it is possible to speak of the reduced mechanical and physiological tolerance of a disk, a synovial joint, the skin, or a functional muscle chain. For example, an osteo-arthritic knee joint has a reduced load-tolerance. The capacity of the cartilage of the knee to adapt to loading has been structurally reduced. Therefore, the functional demands and the patient's movement activities need to be adjusted to help re-establish some balance between the load and loadtolerance. In addition to factors related to regional/local loads and load-tolerance at the levels of tissue, organs, and organ systems, factors can also be identified in relation to general loads and load-tolerance at the level of the person. General load-tolerance means the capacity of the individual to tolerate physical and mental loads. Such loads and loadtolerances must be mutually attuned. This tuning is a continuous process of adaptation. 


\section{Table 5. Key questions in the process of physiotherapist diagnosis}

- What are the patient's symptoms and health problems?

- What is the disorder/disease or damage to tissue/organ?

- Which factors are known to have caused the patient's symptoms and health problems?

- Are the complaints and health problems related to the disorder/discase or damaged tissue/ organ?

- What constitutes deviation from the expected course of the disease and/or health problems?

- Which factors have (had) a positive influence on the course of the patient's health problems?

- Which factors have (had) a negative influence on the course of the patient's health problems?

- What are the objective signs and symptoms related to the patient's health status?

A persistent imbalance between the general (perceived) load and the general (perceived) load-tolerance will, over time, lead to the increasing dysfunction of the person. Dysfunction may be identified in relation to activities in/around the house, and in relation to work, hobbies, recreation and sports. ${ }^{85.144}$

By systematically identifying the load and load-tolerance, at both local and general levels, the physiotherapist can determine which factors may be related to the onset and progression of the patient's complaints and the health problems. This information is critical for determining the appropriate treatment approach.

Inventory the course of the patient's complaints and functional problems. An inventory of the course of the patient's complaints and health problems helps determine whether the course is to be expected based on knowledge of the physiological processes of recovery, clinical epidemiological data, and specific knowledge of medical disorders. If the course followed is not expected, the factors that may influence the course of the health problem need to be identified. Again, the physiotherapist attempts to gain insight into factors in relation to load and load-tolerance, and assesses the connection between them. Attempts are made to trace factors having a negative and positive influence on the course of the health problem. The longer the duration of the health problem, the more difficult it is to discriminate the various factors. Evaluating the factors operative in the course of the health problem is important in the diagnostic process used by the physiotherapist to determine the indications for patient treatment.

Inve'niory the objective signs, symptoms and functional problems. An inventory of the objective signs, symptoms and health problems of the patient helps to obtain the clearest possible picture of the severity of symptoms. This then provides insight into the manifestation of the health problems. The initial inventory compiled from the patient history (subjective) may be supplemented by relevant clinical findings (objective). Together with the medical diagnosis, the referral diagnosis and the referral data, completion of the patient history and inventory of the subjective and objective signs and symptoms should allow the physiotherapist to fully answer the questions set out in Table 5. 
Table 6. Working method with respect to the clinical examination by the physiotherapist

- Perform an examination to elicit any signs and symptoms reported by the patient.

- Perform an examination to elicit any signs and symptoms not reported by the patient, but expected on the basis of the pathology.

- Inventory both the subjective and objective signs and symptoms identified via examination.

- Classify the disorder by medical classification (ICD ${ }^{100}$ or ICPC $^{100}$ ).

- Classify the tissue and/or organ lesions by anatomical classification.

- Classify the findings related to impairment, limitation in activities and/or restriction in participation $\left(\right.$ ICIDH-2). ${ }^{n 7}$

Once these key questions have been answered, the therapist can proceed with the physical examination of the patient to confirm the findings from history taking and/or to supplement the patient profile.

\section{Physical examination}

The objective of examining the patient is that it serves to verify and supplement the patient profile gained from the patient history. After taking the patient history, the physiotherapist should be able to address each of the points outlined in Table 6 .

To conduct the (physical) examination or evaluation, a number of diagnostic tests is available to the physiotherapist. For instance, the process of diagnosis may include somatic sensitivity testing using monofilaments, joint stability testing using manual tests, nerve sensitivity testing by applying a passive stretch to the involved limb, and muscle strength testing using manual or mechanical resistance.

Although the same tests are sometimes employed by physicians, the physiotherapy examination often results in an expansion of the common conceptual-medical framework. In addition to the common conceptual framework, physiotherapists also report findings in terms of functions/structure, activities and participation, ${ }^{63-65,67-72.95 .134,135}$ embryology (segments) and anatomy. ${ }^{153,154}$ physiology (tissue repair, adaptation), ${ }^{155,156}$ neurophysiology (segmental regulation, control systems), ${ }^{144,155,157,158}$ psychology (specific and nonspecific arousal, perceptions, coping behaviour), ${ }^{144.158-162}$ biomechanics (mechanical load-tolerance of tissues). ${ }^{154.163}$ and motor learning processes. ${ }^{164.165}$ The physiotherapist's systematic examination and reporting of findings provides the basis on which the patient profile based on history taking may be confirmed and supplemented.

\section{Physiotherapy diagnosis}

The diagnostic process is completed when the physiotherapist's diagnosis has been made and the indication for physiotherapy established. The physiotherapist's diagnosis may be defined as "a specific professional opinion on the health status of the patient, related to the underlying suffering and based on data from the referral, the history taking, and the clinical examination supplemented by medical and psychosocial data" ${ }^{26}$ The physiotherapy diagnosis should contain "clusters" of: (a) the underlying disorder (medical diagnosis); (b) an estimate of the balance between load and load-tolerance; (c) the psychosocial context 
of the problems; (d) related impairments, limitations in activities, and restriction in participation; and (e) an estimation of the mechanisms of adaptation.

Such profiles of individual patients may, in time, lead to clustered diagnosis groups (practice patterns) based on the physiotherapy diagnosis. Developing such clusters is not an easy task, but it has a high priority both in the context of the appropriate use of physiotherapy and in the context of defining inclusion and exclusion criteria for a research population for an RCT. There are indications that such clusters may have a prognostic value with respect to the number and duration of treatments and a predictive value with respect to the functional prognosis, ${ }^{166-174}$ In any case, it is clear that the physiotherapy diagnosis will rarely consist of a single term, as does the medical diagnosis.

At the end of the diagnostic process, the physiotherapist must state the appropriateness of physiotherapy for the particular patient. Thus, after the physician has indicated physiotherapy, it is the physiotherapist's role to confirm whether there is an indication for physiotherapy treatment and to determine what treatment tools and treatment plan will best suit the needs of the patient in accordance with the current state-of-the-art body of knowledge. When there is no agreement about the indication setting the physiotherapist should communicate this to the referring physician.

\section{Process of treatment and evaluation}

During the process of treatment it is important to evaluate and monitor the response of individual patients, which requires adequate, valid and responsive outcome measures that accurately reflects the patient's response to treatment. Therapists are encouraged to select adequate outcome measures that capture specific patient responses to clinical outcomes, function, well-being and patient satisfaction. Patients with the same medical diagnostic classification (ICD-10) ${ }^{109}$ will often have a different array of problems in functioning (e.g. impairments, limitations in activities, and restriction in participation). Concurrent evaluation during the process of treatment will yield information for the practitioner and assist their insight in the possible relationship between the patient's functional problems, therapist's treatment goals/objectives, the planned interventions and the patient's response to treatment (e.g. outcomes).

\section{Formulation of the treatment plan}

The following elements comprise the treatment plan: (a) the treatment objectives and outcome measures; (b) the treatment strategy; (c) treatment procedures; (d) prognosis of the treatment duration (including the number of treatment sessions); and (e) the expected outcome.

Treatment objectives. Treatment objectives are formulated, together with the patient, and often include the main complaints of the patient (e.g. in terms of impairments, limitation in activities and restriction in participation) as far as they can be influenced by physiotherapy. It is important to consider whether treatment objectives should be set at the level of impairments (i.e. reducing pain resulting from tissue damage), or at the level 
of activities (i.e. improving elementary locomotor activities), or at the level of participation, or a combination of these three. ${ }^{25,64.99,166}$ Furthermore, it is important to consider whether treatment objectives should be based on an anticipated functional recovery, or on teaching compensatory activities when functional recovery is not expected. There are sufficient indications that in patients with chronic benign pain (longer than 6 to 12 weeks), the treatment objectives must be strongly stated in terms of improving elementary activities, improving general exercise capacity, and providing ergonomic adaptations in the work place, rather than on decreasing pain. . $^{25} .152 .159 .160 .175-177$ While the main reason for physiotherapy intervention is to eradicate the disability caused by the current health problem, considerable attention is focused upon prevention of recurrences to prevent the development of chronicity and serious disability.

Treatment objectives may be concurrent or consecutive. For example, consecutive treatment objectives may be indicated when complex motor activities cannot be re-learned until elementary motor activities are adequately mastered.

On the other hand, concurrent treatrnent objectives may be met by strengthening, for example, a weak medial quadriceps (muscle strength greater than "grade $3^{\prime \prime}$ ) via stairwalking, for the patient who reports a limitation in the ability to walk up and down stairs.

Trealment strategy. Choosing between concurrent or consecutive treatment objectives implies a treatment strategy. Many patients lack insight into the connection between their impairments, limitation in activities, and restriction in participation. Many patients remain focused on pain as an expression of tissue damage, and often do not realize that pain may be maintained by, for example, inadequate coping behaviour. ${ }^{159,160}$ The result is a pain behaviour that is characterized by a progressive decline in physical activities and by an increase or expansion of symptoms, such as insomnia. ${ }^{132,152,159,160}$ For these patients, consecutive treatment objectives should be formulated. Reaching one treatment objective (i.e. re-conceptualizing pain as an expression of behaviour rather than tissue damage) is prerequisite to the next treatment objective (i.e. improving elementary motor activities such as bending, lifting, carrying). Treatment is often directed at the psychological aspect of the disorder with the patient's anger or anxiety being addressed to re-establish normal movement. Improving elementary motor activities is, in its turn, prerequisite to improving applied activities. Hence, al hierarchy in treatment objectives develops.

Treatment procedures. The choice of treatment procedure(s) is the result of complex considerations. For instance, joint mobility may be improved by manual mobilization techniques and/or exercises (activities). Likewise, pain may be reduced by electrotherapy and/or massage and/or active: exercise..$^{64,137,138,166}$ The physiotherapist must determine which treatment procedure or combination of procedures will result in the greatest degree of recovery. 
Table 7. The main categories of physiotherapeutic procedures

- History taking

- Physical examination

- Manual techniques (i.e. massage and joint/limb mobilization)

- Physical agencies/modalities (i.e. electrotherapy)

- Therapeutic exercising and retraining of functions and activities

- Education (including information and advice)

- Instrumental techniques

- Medication techniques (i.e. iontophoresis)

- Provision of assistive devices

- Other procedures

Adapted from Heerkens, et al. ${ }^{1 \%}$

Table 7 outlines the nine main categories of treatment procedures set forth in the Draft Classification of Procedures for Health Professions. ${ }^{179}$ Inherent to several of these procedures is the importance of coaching, whereby the physiotherapist encourages the patient's functional performance and recovery.

Apart from deliberations with respect to the choice of procedures in relation to the treatment objective, questions of scientific evidence play an increasing role in making a choice between procedures. For instance, there is no scientific evidence supporting the effectiveness of mechanical traction in patients with nonspecific back pain. ${ }^{51,186}$ Therefore, it may be argued that traction is not a viable option for treatment of nonspecific back pain. With the exception of Transcutaneous Electrical Nerve Stimulation (TENS), ${ }^{45.181}$ there is little to no scientific evidence to warrant the use of various types of mechanical therapy ${ }^{51}$ and electrotherapy..$^{38,40,43,44,129-131}$

There is however, ample scientific evidence of the effectiveness of exercises and regulation of functions and motor activities in certain categories of patients, such as patients with asthma or COPD, ${ }^{52.78,79.182 .183}$ urinary-incontinence, ${ }^{46,47.184 .187}$ intermittent claudication, ${ }^{53,188,189}$ chronic back pain ${ }^{38,40,128-132}$ arthrosis of the hip and knee, ${ }^{54,190 \cdot 192}$ acute ankle sprain ${ }^{35.193}$ and benign paroxysmal vertigo ${ }^{194-196}$ For other categories of patients, scientific evidence regarding the efficacy of exercise and regulation of functions and motor activities remains unclear (e.g. Parkinson's disease, ${ }^{197}$ epicondylitis ${ }^{19,198}$ ).

All in all, a clearer picture is emerging with regard to the efficacy, effectiveness and efficiency of various physiotherapeutic procedures. Making evidence-based choices for treatment procedures has become part of the professional development of physiotherapy. ${ }^{13.25 .69 \cdot 72}$

Prognosis of the treatment duration. The treatment duration (including the number of treatment sessions) is related to the natural course of recovery and to the expected outcome (prognosis). In establishing the prognosis, physiotherapists must predict the extent to which complaints and symptoms will be reduced, and/or health status improved/ stabilized. 
Additionally, the physiotherapist must determine the duration of the treatment episode and the number of treatment sessions required to realize treatment objectives, and the likelihood of recurrence of symptoms or problems.

A prognosis of the patient's actual health problem may be determined on the basis of clinical epidemiological data, and on the basis of professional experience. The prognosis of the outcome on functional health status is based on weighing various factors:

- the medical diagnosis, the referral diagnosis and data - in particular, the nature and severity of the disorder/disease (aetiology, morbidity, mortality), and the co-morbidity;

- the nature and severity of the patient's symptoms and complaints and his/her reason for encounter;

- the nature and severity of the findings from the clinical examination including findings related to functions and activities not affected;

- the duration of the health problem;

- the course of the health problem over time, and any changes as a result of the current therapeutic interventions;

- the age of the patient with respect to decreased capacity to recover and adapt with increasing age;

- the extent to which the patient is able to control the level of symptoms, functions, abilities and participation.

Forming an adequate prognosis is not an easy task since the prognosis depends on intraand extra-individual factors that are often not under the control of the physiotherapist. In addition to the above-mentioned factors, many mental (psychological), emotional, and environmental (home and work) aspects may influence the patient's ability to recover. A physiotherapist's professional expertise and experience often play an important role in establishing the prognosis for treatment duration.

Expected outcome. Based on the determined treatment objectives, strategies and duration, the physiotherapist must determine the expected outcome of the patient's treatment. Clearly, the physiotherapist's process of diagnosis is critical in predicting outcome, since it is not possible to make a well-founded statement on the basis of the medical diagnosis alone. ${ }^{25,63-65,171,199}$

\section{Treatment}

The objectives of physiotherapeutic treatment may be formulated in terms of reducing impairments (in functions/structures), limitation in activities, and restriction in participation, and influencing environmental or personal factors. During the treatment period, the concurrent and consecutive treatment objectives are systematically pursued by means of specific clinimetric procedures. Changes in the health status of the patient must be evaluated. Part of this evaluation is an analysis of any failure to achieve the expected outcome. Based on periodic evaluation, both the treatment plan and prognosis may need to be adjusted. In this way, treatment will be focused not only on changes in the patient's 
functional status, but also on the necessity, efficiency, and effectiveness of the physiotherapeutic care.

\section{Treatment conclusion, report, and documentation}

There are several reasons why the treatment period may be concluded. The ideal reason is that the patient's problem in functioning has been completely resolved. Another reason may be that the functional status of the patient has improved to an adequate level of function, activities, participation and quality of life. In this case, there is an optimal balance between load (burden) and load-tolerance (ability to adapt), and the course to full recovery (normal recovery) can be expected. However, it might also be that the patient is able to function, albeit at a lower level than before the health problem, and no further improvement is expected from a longer treatment period. For example, approximately $15 \%$ of people with protracted symptoms (longer than 12 months) resulting from a whiplash-type of injury are able to keep their symptoms under control by making changes in their way of life; thus balancing load and load-tolerance. ${ }^{200}$ In this patient population, it is unlikely that symptoms will completely resolve, or functioning will return to the preinjury level. Because treatment intervention for patients with chronic benign pain cannot be expected to result in the elimination of pain, treatment should be focused on promoting movement activities, participation and maintenance of optimal pain control.

Reaching time-limited treatment objectives set in consultation with the patient is also an indication for concluding treatment. In the case of chronic benign pain, complaints cannot be expected to disappear even if the treatment period is endless.

Finally, treatment may need to be concluded if the patient's health status deteriorates and an adjustment of the treatment plan will not result in an amelioration of the patient's health status. In this case, prior to conclusion of treatment, the physiotherapist should try to find the reason for the deterioration.

Regardless of the reason for concluding treatment, a written report is generally sent to the referring physician. In this report, the treatment objectives (set and obtained), the improvements in functioning, perceived quality of life, and the reason for concluding treatment should be stated.

\section{Comment}

Improving the quality of physiotherapeutic care requires a systematic and multilevel system approach of physiotherapy diagnosis, treatment, process and outcome evaluation. Feedback reference to the process of "indication-setting physiotherapy" (see Figure 1) forces the systematic approach of physiotherapy diagnosis to answer questions related to the general objectives of the physiotherapist's diagnostic process (see Table 5). In this way, it is possible to promote cooperation with the referring physician; as a result, physiotherapy will become more transparent to the referrer. 
The physiotherapy profession is fully committed to professional development based on self-regulation. Sound professional diagnosis is a prerequisite for adequate indication setting, for scientific research, and for the advancement of the quality of physiotherapy treatment. However, within the international professional body, there is yet no clear consensus about the form of the physiotherapist's diagnosis. Yet, it is clear that a diagnosis stated in the terminology of the profession is important for physiotherapeutic procedures (objectives and strategy) and for the appropriate evaluation of outcome. Furthermore, a professional diagnosis is important in establishing a position and function for the professional body within the arena of health care providers.

The pressure to prove the efficacy and effectiveness of physiotherapy has, understandably, led to conduct of a large number of clinical trials. Unfortunately, many of these trials have been of inadequate quality in terms of methodology and, in particular, in terms of content. The physiotherapy profession has failed so far to provide good evidence-based practice, in terms of both quantity and quality, to legitimize its role in the health care system. ${ }^{13,25,60.201}$ Physiotherapy does not benefit from this state of affairs and, at present, a premafure RCT is too offen the wrong option. However, without improved controlled study designs, reliable and valid outcome measures, and interpretation of data, little progress in this area can be expected. At the same time, the focus of research should be on conducting studies that add to our understanding of the impact of physiotherapy services, rather than limiting efforts to studies whose merits reside largely in the elegance of their design or execution. Descriptive and epidemiological studies that provide insight into courses of recovery ${ }^{91.92}$ and into the nature and practice of physiotherapy may be of greater value. More recently, physiotherapy research has begun to develop both theoretical perspectives for patient care, and to address the paucity of former studies in the field by designing controlled studies that incorporate methodology that more accurately reflects the way physiotherapists actually practice. $35,55,76,82-84,134,135,176-178,202$ However, a crucial component of physiotherapy treatment is the extent to which patients follow the physiotherapist's advice and recommendations, ${ }^{203-205}$ patient adherence to therapy is essential to assessing its effectiveness. ${ }^{202,206-208}$ The extent of compliance with the physiotherapist's advice, and the patient's adherence to treatment is an important factor in treatment. In order to achieve positive results of physiotherapy, patients have to incorporate the learned abilities into daily life. The physiotherapist is an important mentor in this behaviour modification. Patient education is a very important aspect of this kind of care and a professional attitude toward providing relevant information is required. ${ }^{209}$ Patient preferences are therefore seen by some as a key element in evidence-based practice. ${ }^{203-206}$ It is suggested in the literature that an enhanced decision-making role for patients improves both patient satisfaction and their adherence to treatment and recommendations. Although there is some evidence that patient compliance and patient preferences are important factors in achieving more beneficial patient outcomes, it was beyond the scope of this paper to investigate this aspect of treatment. 
Development and dissemination of national evidence-based practice guidelines, in which the state-of-the-art process of diagnosis and treatment is described, is one of the cornerstones of the process of professional development in the Netherlands. ${ }^{69-72}$ However, individual practitioners should take responsibility for ensuring that their continuing education incorporates both research knowledge and a constant appraisal of relevant literature in their particular field, to implement relevant findings into clinical practice. ${ }^{69-72.210} \mathrm{Next}$ in importance to the development of professional scope are the development of "cluster diagnosis" groups in order to differentiate patient demands on physiotherapy; the improvement of the efficacy and effectiveness of physiotherapy; and the advancement of reciprocal monitoring, clinical auditing, and benchmarking ${ }^{71,72,211}$

Methodical procedures will also clarify the diagnostic and therapeutic processes of physiotherapy for the referrer, leading to improved interdisciplinary communication. Along with the medical conceptual framework, physiotherapists use a conceptual framework derived from the ICIDH ${ }^{63-73,135,136}$ and other classifications to describe the patient's functional (health) status on three distinct levels relevant to physiotherapy practice and communication. The beta- 2 draft (ICIDH-2) allows physiotherapists to classify the negative components in terms of impairments, limitation in activities and restriction in participation, and also the neutral components in terms of functions, activities, and participation that have not been affected. ${ }^{63,87,68,135.136}$ This is important because unaffected functions and activities are involved in treatment, for example, in learning compensatory activities or other movement strategies. When the health status of the patient is described in terms of (impairments in) "function/structure," (limitation in) "activities," and (restrictions in) "participation," certain aspects of a person's health problem may be revealed via the relationship of impairments, limitation in activities, and restriction in participation between each other and in relation to each other. Epidemiological data have shown large variability in such relationships. ${ }^{64,65.76,80,89,90.111,139-143,168, .770}$ A clear and more general relationship such as simultaneously occurring symptoms in a medically verbalized syndrome have not been described. The communication between referrers and physiotherapists would improve considerably by reporting on the health status of the patient at the level of (changes in) activities, and effects at the level of participation and quality of life. Treatment objectives could be pursued not only concurrently (simultaneously), but often consecutively (in succession). Insight into the hierarchy of consecutive treatment objectives is important in establishing the prognosis of the treatment duration and the number of treatment sessions.

\section{Conclusion}

In conclusion, communication demands regular consultation between referrer and physiotherapist in order to understand each other's conceptual framework. While the medical diagnosis may be agreed upon, an additional functional (physiotherapy) diagnosis and expansion of the conceptual framework is needed to define the patient's functional problem in the context of physiotherapy practice. 
It has yet to be formally determined as to whether the present clinical practice produce the best effect. The information necessary for such a conclusion amply exists. Valid outcome research is needed to shed light on the efficacy, effectiveness and efficiency of physiotherapy practice; there is a growing need for greater clarity to legitimize physiotherapy's role and position in the health care system.

\section{References}

1. Centraal Bureau voor de Statistiek (CBS). Statistisch Jaarboek 1997. Voorburg: CBS, 1997.

2. Rijken PM, van Heugten CM, Dekker J. Brancherapport paramedische zorg. Utrecht: Nederlands instituut voor onderzoek van de gezondheidszorg (Nivel), 1996.

3. de Haan EA, van Dijk JP, Hollenbeek Brouwer J. Mening van cliēnten over de kwaliteit van fysiothera*. pic. Ned Tijdschr Fysiother 1995;95:18-22.

4. Harteloh PPM, Verweij GCC. Gezondheidsenquete, de mening van tevredenheid over huisarts, tandarts, fysiotherapeut en specialist. Maandbericht gezondheidsstatistiek. 1995;14:4-18.

5. Scholte op Reimei WJM, de Haan RJ, Limburg M, van den Bos GAM. Tevredenheid over zorg van patiënten met een beroerte. TSG 1997;75:511-517.

6. Anoniem. Veel mensen vinden baat bij fysiotherapie. Consumentengids 1992;10:640-643 .

7. Anoniem. Patiêntenvoorlichting kan klantvriendelijker. Consumentengids 1995;3:174-175.

8. Twoney LT. Editorial $=$ Research, more essential than ever. Physiotherapy Research International 1996; : : iii-iv.

9. Beckerman H, Bouter L (eds). Effectiviteit van fysiotherapie: een literatuuronderzoek. Maastricht: Rijksuniversiteit Limburg, 1991.

10. Beckerman H, Bouter LM, Heijden GJMG van der, Bie RA de, Koes BW. Efficacy of physiotherapy for musculoskeletal disorders: what can we learn from research? Brit J Gen Pract 1993;43:73-7.

11. Bouter LM, Beckerman H. van der Heijden GMJG, Koes BW, de Bie RA. Effectiviteit van fysiotherapie; een samenvatting van 9 meta-analyses. Ned Tijdschr Geneeskd 1992;136:1058-1061.

12. Koes BW. Editorial - Now is the time for evidence based physiotherapy. Physiotherapy Research International 1997;2:iv-v.

13. Newman DJ. Physiotherapy for best effect. Physiotherapy 1997:83:5-11.

14. Ashburn A. Partridge C. De. Souza L. Physiotherapy in the rehabilitation of stroke. Clinical Rehabilitation 1993:7:337-345.

15. Higgs J, Jones $\mathbf{M}$. Clinical reasoning. In: Higgs J, Jones $\mathbf{M}$ (eds): Clinical reasoning in the health professions. London: Butterworth-Heineman, 1995.

16. Higgs J, Titchen A. Research and knowledge. Physiotherapy 1998;84:72-80.

17. Sahrmann SA. Diagnosis and classification by the physical therapist - a prerequisite for treatment: a special communication. Phys Ther 1988:68:1703-1706.

18. Sahrmann SA. Moving precisely? Or taking the path of least resistance? Phys Ther 1998;78:1208-1218.

19. Jette AM. Physical disablement concepts for physical therapy research and practice. Phys Ther 1994; 74:380-386.

20. Jette AM. Outcomes research: shifting the dominant research paradigm in physical therapy. Phys Ther 1995;75:965-970.

21. Rothstein JM. Editor's note - When thoughtfulness dies. Phys Ther 1996;76:342-343.

22. Cott CA, Finch E, Gasner D. Thomas SG, Verrier MC. The movement continuum theory of physical therapy. Physiother Canada 1995:47:87-95.

23. Jones M. Clinical reasoning: the foundation of clinical practice. Part 1. Australian Physiotherapy 1997:43: 167-170.

24. Jones M. Clinical reasoning: the foundation of clinical practice. Part. 2. Australian Physiotherapy 1997:43:213-217. 
25. Oostendorp RAB, van Ravensberg CD, Wams HWA, Heerkens YF, Hendriks HJM. Fysiotherapie, wat omvat het? Bijblijven 1996:12:5-17.

26. Goldby L. Low back pain: the evidence for physiotherapy. Phys. Ther. Rev, 1997:2:7-11.

27. Foster NE. Researching low back pain? An overview of the pitfalls. Phys. Ther. Rev, 1998:3:9-17.

28. Pocock SJ. Clinical trials: a practical approach. Chichester: Wiley \& Sons, 1991.

29. Sackett DL, Richardson WS, Rosenberg WMC, Haynes RB. Evidence-based medicine. New York: Churchill Livingstone, 1997.

30. Meinert CL. Clinical trials: design, conduct and analysis. New York: Oxford University Press, 1986.

31. Grimshaw JM, Russel I. Development and implementation of practice guidelines. Qual Health Care $1995 ; 4: 1317-1322$.

32. Oostendorp RAB, Wams HWA, Bernards ATM. Understanding the basics of physical therapy: the main condition for improving the quality of physical therapy. In: Dekker J, Oostendorp RAB (eds). Improving the quality of physical therapy: invited lectures. Utrecht / Amersfoort: Netherlands institute of primary health care (Nivel) / Dutch national institute for the allied health professions (NPi), 1995.

33. Rothstein JM. Science and practice: examining outcomes. In: Dekker J, Oostendorp RAB (eds). Improving the quality of physical therapy: invited lectures. Utrecht / Amersfoort: Netherlands institute of primary health care (Nivel) / Dutch national institute for the allied health professions (NPi), 1995.

34. Bouter LM. Improving the quality of clinical trials in physical therapy. In: Dekker J, Oostendorp RAB (eds). Improving the quality of physical therapy: invited lectures. Utrecht / Amersfoort: Netherlands. institute of primary health care (Nivel) / Dutch national institute for the allied health professions (NPi), 1995.

35. de Bie RA. Efficacy of $904 \mathrm{~nm}$ laser therapy in acute lateral ankle sprains ( $\mathrm{PhD}$ Thesis). Maastricht: Datawyze/Maastricht University Press, 1998.

36. de Bie RA. Methodology of systematic reviews: an introduction. Phys. Ther. Rev. 1996;1:47-51.

37. Bjordal JM, Greve G. What may alter the conclusions of reviews? Phys. Ther. Rev. 1998;3:121-132.

38. van Tulder MW. Diagnostics and treatment of chronic low back pain in primary care (PhD Thesis). Amsterdam: Vrije Universiteit (VU), 1996.

39. de Vet H, de Bie R, Bouter LM, et al. Systematic reviews on the basis of methodological criteria. Physiotherapy 1997;83:284-289.

40. van Tulder MW, Koes BW, Bouter LM. Conservative treatment of acute and chronic nonspecific low back pain. A systematic review of randomized controlled trials of the most common interventions. Spine 1997;22:2128-2156.

41. Verhagen AP, de Vet HCW, de Bie RA, et al. The Delphi list: a criteria list for quality assessment of randomized clinical trials for conducting systematic reviews developed by Delphi consensus. J Clin Epid 1998;51:1235-1241.

42. Chalmers TC, Smith H, Blackburn B, et al. A method for assessing the quality of a randomized controlled trial. Controlled Clin Trials 1981;2:31-49.

43. Koes BW, Bouter LM, van der Heijden GJMG. Methodological quality of randomized clinical trials on treatment efficacy in low back pain. Spine 1995;20:228-235

44. Koes BW, Assendelft WJJ, van der Heijden GJMG, Bouter L.M. Spinal manipulation for low back pain. An updated systematic review of randomized clinical trials. Spine 1996;21:2860-2873.

45. Feine JS, Lund JP. An assessment of the efficacy of physical therapy and physical modalities for the control of chronic musculoskeletal pain. Pain 1997,71:5.23.

46. Berghmans LCM, Hendriks HJM, Bo $\mathrm{K}$, et al. Conservative treatment of stress urinary incontinence in women: a systematic review of clinical trials. Br J Urol 1998;82:181-191.

47. Berghmans LCM, Hendriks HJM, de Bie RA, et al. Conservative treatment of urge urinary incontinence in women: a systematic review of clinical trials. Br J Urol 2000;85:25:4-263.

48. de Bie RA, Verhagen AP, Lenssen AF, et al. Efficacy of conservative interventions in the treatment of acute lateral ankle sprains: a systematic review. In: de Bie RA. Efficacy of $904 \mathrm{~nm}$ laser therapy in acute lateral ankle sprains [PhD Thesis]. Maastricht: Datawyze/Maastricht University Press, 1998.

49. de Bie RA, Verhagen AP, Lenssen AF, et al. Efficacy of $904 \mathrm{~nm}$ laser therapy in musculoskeletal disorders: a systematic review. Phys. Ther. Rev. 1998;3:59-72.

50. van der Heijden, van der Windt DAWM, de Winter AF. Physiotherapy for soft-tissue shoulder disorders: a systematic review of randornized clinical trials. BMJ 1997:315:25-30. 
51. van der Heijden GJMG, Beurskens AJHM, Koes BW, et al. The efficacy of traction for back and neck pain: a systematic blinded review of randomized clinical trial methods. Phys Ther 1995;75:93-104.

52. Cambach W, Wagenaar RC, Koelman TW, van Keimpema ARJ, Kemker HCG. The long-term effects of pulmonary rehabilitation in patients with astma and chronic obstructive pulmonary disease: a research synthesis. Arch Phys Med Rehabil 1999;80:103-111.

53. Brandsma JW, Robeer GG, van den Heuvel S, et al. Effect of exercises on walking distance of patients with intermittent claudication: study of randomized clinical trials. Phys Ther 1998;78:278-288.

54. van Baar ME, Assendelft WJ, Dekker J. Oostendorp RAB, Bijlsma JWJ. Effectiveness of exercise therapy in patients with osteoarthritis of the hip or knee: a systematic review of randomised clinical trials. Arthritis Rheum 1999:42(7): 1361-1369.

55. Kwakkel G. Dynamics in functional recovery after stroke [PhD Thesis]. Amsterdam: Ponsen \& Looijen BV, 1998.

56. Kwakkel G, Wagenaar RC, Koelman TW, et al. Effects of intensity of stroke rehabilitation. A research synthesis. Stroke 1997;28:1550-1556.

57. Kwakkel G, Kollen BJ, Wagenaar RC. Therapy impact on functional recovery in stroke rehabilitation. A critical review of the literature. Physiotherapy 1999:85:377-391.

58. van der Wijden CL, Overbeke AJPM. Gerandomiseerde klinische trials in het Nederlands Tijdschrift voor Geneeskunde. Ned Tijdschr Geneeskd 1993;137:1607-1610.

59. Field MJ, Lohr KN (eds). Guidelines for Clinical Practice. From development to use. IOM, Washington DC, National Academy Press, 1992.

60. Partridge CJ. Editorial - The patient as decision maker. Physiotherapy Research International 1997;2:ivvi.

61. van der Heijden. Shoulder disorder treatment. Efficacy of ultrasoundtherapy and electrotherapy [PhD thesis]. Maastricht: Datawyse / Maastricht University Press, 1996.

62. van der Windt, Koes BW, Boeke AJP, et al. Shoulder disorders in general practice: prognostic indicators of outcome. British Journal of General Practice 1996;46:519-523.

63. Heerkens YF, Brandsma JW, Lakerveld-Heyl K, Ravensberg van CD. Impairments and disabilities - The difference. Proposal for Adjustment of the International Classification of Impairments, Disabilities, and Handicaps. Phys Ther 1994;74:430-442.

64. Dekker J, van Baar ME, Curfs EChr, Kerssens JJ. Diagnosis and treatment in physical therapy; an investigation of their relationship. Phys Ther 1993;73:568-580.

65. Dekker J. Application of the ICIDH in survey research on rehabilitation: the emergence of the functional diagnosis. Disabil Rehabil. 1995;17:195-201.

66. Jette AM. Diagnosis and classification by physical therapists. Phys Ther 1989:69:967-969.

67. Hendriks HJM, Wagner C, Brandsma JW, et al. Experiences with physiotherapsist's consultation. Results of a feasibility study. Physiother Theory Prac. 1996;12:211-220.

68. HJM, Hendriks, JW Brandsma, YF Heerkens, RAB Oostendorp, RM Nelson. Intra- and interobserver reliability of the assessment of the functional health status in physical therapy. Phys Ther 1997:77:10971106.

69. Hendriks HJM, Reitsma E, van Ettekoven H. Centrale Richtlijnen in de fysiotherapie: introductie van het Centrale Richtlijnen (CR)-project. Ned Tijdschr Fysiother 1996:106:2-11.

70. Hendriks HJM, van Ettekoven $\mathrm{H}$, Reitsma E, van der Wees $\mathrm{Ph}$. Eindverslag van het project Centrale Richtlijnen (CR) in de Fysiotherapie. Deel I: achtergronden en evaluatie van het project. Amersfoort/Utrecht: KNGF/CBO/NPi, 1998.

71. Hendriks HJM, van Ettekoven H, Reitsma E, Verhoeven A, van der Wees Ph. Methode voor centrale richtlijnontwikkeling en implementatie in de fysiotherapie. Amersfoort/Utrecht: KNGF/CBO/NPi, 1998.

72. Hendriks HJM, Bekkering GE, Brandsma JW, et al. Development and implementation of national practice guidelines: a prospect for continuous quality improvement in physiotherapy. An introduction to the method of guideline development (Part I). Physiotherapy 2000;86:535-547.

73. Whyte J. Toward a methodology for rehabilitation research. Am J Phys Med Rehabil. 1994:73: 428-435.

74. Rose S. Physical therapy diagnosis: role and function. Phys Ther 1989:69:535-537.

75. Guccione AA. Physical therapy diagnosis and the relationship between impairments and function. Phys Ther 1991:71:499-504. 
76. Delitto A. Are measures of function and disability important in low back pain? Phys Ther 1994;74:452. 462.

77. Enderby P, Kew E. Outcome measurement in physiotherapy using the World Health Organisation's Classification of Impairment, Disability and Handicap: A pilot study. Physiotherapy 1995;81: 177-180.

78. Bekkering GE, Hendriks HJM, Paterson WJ, et al. Guidelines for the physiotherapeutic management in chronic obstructive pulmonary disease (COPD). Phys. Ther. Rev, 2000;5:59-74.

79. Bekkering GE, Hendriks HJM, Chadwick-Straver RVM, et al. KNGF-richtlijn COPD. Ned Tijdschr Fysiother 1998:108: supplement no. 3.

80. Jette D, Manago D, Medved E, et al. The disablement process in patients with pulmonary disease. Phys Ther 1997;77:385-394.

81. Pashkow P. Outcomes in cardiopulmonary rehabilitation. Phys Ther 1996;76:643-656.

82. van Baar ME, Dekker J, Oostendorp RAB, et al. The effectiveness of exereise therapy in patients with osteoarthritis of knee or hip: a randomized clinical trial. J Rheumatol 1998:25:2432-2439.

83. Oerlemans HM, Oostendorp RAB, de Boo T, et al. Randomised controlled trial of adjuvant physiotherapy or occupational therapy in reflex sympathetic dystrophy / complex regional pain syndrome of the upper extremity. Pain (in press).

84. Kwakkel G, Wagenaar RC. Twisk JWR, Lankhorst G, Koetsier JC. Intensity of leg and arm training after primary middle-cerebral-artery stroke: A randomised clinical trial. Lancet 1999;354:191-196.

85. Bernards ATM, Hagenaars LHA, Oostendorp RAB, Wams HWA. Het meerdiemsionale belastingbelastbaarheidsmodel: een conceptueel model voor de fysiotherapic. Ned Tijdschr Fysiother 1999;109:58. 65.

86. Verbrugge LM, Jette AM. The disablement process. Soc Sci Med 1994;38:1-14

87. World Health. Organization (WHO). Internationall Classification of Impairments, Activities and Participation: a manual of dimensions of disablement and functioning (ICIDH-2). Geneva: WHO, 1997.

88. Nagi SZ. Some conceptual issues in disability and rehabilitation. In: Sussman M (ed). Sociology and rehabilitation: 100-113. Washington DC: American Social Association, 1965.

89. Jette DU, Jette AM. Physical therapy and health outcomes in patients with spinal impaiments. Phys Ther 1996;76:930-941.

90. Jette DU, Jette AM. Physical therapy and health outcomes in patients with knee impairments. Phys Ther 1996:76:1178-1186.

91. Vandenbroecke JP. Case reports in an evidence-based world. JR Soc Med 1999;92:159-1933.

92. Sackett DL, Weinberg JE. Choosing the best research design for each question. BMJ 1997:315:1636.

93. Barrow HS, Feltovich PJ. The clinical reasoning process, Med Educ 1987;21:86-91.

94. James G. Editorial - The clinical reasoning process. Brit J Ther Rehab 1999;6(8):368.

95. Koninklijk Nederlands Genootschap voor Fysiotherapie (KNGF). Richtlijnen voor de fysiotherapeutische verslaglegging. Amersfoon: KNGF, 1993.

96. Verhoeven ALJ, van den Heuvel CMF. KNGF-Richlijn informatieverstrekking huisarts. Amersfoort: Koninklijk Nederlands Genootschap voor Fysiotherapie (KNGF), 1997.

97. Nationale Raad voor de Volksgezondheid (NRV), Discussienota "Begrippenkader voor de beroepsuitoefening". Zoetermeer: NRV, 1986.

98. Rijksinstituut voor de Volksgezondheid en Milieu (RIVM). Volksgezondheid Toekomstverkenningen 1997. Effecten van zorg. Bilthoven: Elsevier / de Tijdstroom, 1997.

99. Kerssens JJ, Curfs EChr. Extramurale fysiotherapie (PhD thesis). Utrecht: Netherlands institute of primary care (Nivel), 1993.

100. Kerssens JJ, Groenewegen PP. Referrals to physical therapy: the relation between the number of referrals, the indication for referral and the inclination to refer. Soc Sci Med 1990;30:797-804.

101. Jette DU, Jette AM. Professional uncertainty and treatment choices by physical therapists. Arch Phys Med Rehab 1997:78:1346-1351.

102. Post D, van Zanten A. Hoe nodig is fysiotherapie? Medisch Contact 1992;19:590-593.

103. van der Rijdt $T$, Lubbers $M$. Kolker $L$. Het verbeteren vars samenwerking. Eindverslag van het project Samenwerking Huisarts en Fysiotherapeut. Utrecht: Stichting O\&O, 1990.

104. Hendriks HJM, Wagner C, Brandsma JW, Dekker J. Evaluatie van het consultatief fysiotherapeutisch onderzock in de eertse lijn. Resultaten van een veldexperiment. Utrecht: Nederlands instituut van de gezondheidszorg (Nivel), 1994. 
105. Hendriks HJM, Kerssens JJ, Dekker J, Oostendorp RAB, van der Zee J, Nelson RM. Physical therapist consultation in general practice: its use and impact on the process of care. Phys Ther (accepted)

106. American Physical Therapy Association (APTA). Guide to physical therapist practice. Phys Ther 1997;77:1163-1650.

107. Hendriks HJM, Wagner C, Brandsma JW, et al. Het consultatief fysiotherapeutisch onderzoek (CFO) in de eerste lijn. informatie uit de literatuur en introduktie van het CFO-project. Ned Tijdschr Fysiother 1992;102:176-183.

108. Bersee A.PM, Pluimakers WHMA. De Wet BIG: de betekenis van de nieuwe wetgeving voor beroepsbeoefenaren in de gezondheidszorg. Lelystad: Vermande, 1993.

109. World Health Organization (WHO). International Classification of Diseases and Related Health Problems (ICD-10), Geneva: WHO, 1993.

110. Lamberts H, Wood M. International Classification of Primary Care (ICPC). Oxford: University Press Dxford, 1987.

111. Dekker Jy van Baar ME (eds). Beleidsgericht Evaluatie- en Effectonderzoek Extramurale Fysiotherapie 1989-1992. Utrecht: Nederlands instituut voor onderzoek van de gezondheidszorg (Nivel), 1995.

112. van den Bosch WJHM. Coumans RHM, Verkerk S, van Weert H. NHG-Standaard Enkeldistorsie. Huisarts Wet. 1989:32:523-526.

113. Bonsema K, Boutens EJ, Kaiser V', Stoffers HEJH. NHG-Standaard Perifeer Arterieel Vaatlijden. Huisarts Wet 1990:33:440-446.

114. Schuurman W, van Aiphen-Jager JM, van den Bosch WJHM, et al. NHG-Standaard. Reumatoide Artritis. Huisarts Wet 1994;37:248-259.

115. Lagro-Janssen ALM, Breedveldt-Boer HP, van Dongen JJAM, et al. NHG-Standaard Incontinentie voor Urine. Huisarts Wet 1995;38:71-80.

116. Walma EP, Bakx HCA, Besselink RAM, et al. NHG-Standaard Hartfalen. Huisarts Wet 1995;38:471-487.

117. Faas A, Chavannes AW, Koes BW, et al. NHG-Standaard Lage-Rugpijn. Huisarts Wet: 1996;39:18-31.

118. Smeele IJM, van den Hoogen JMM, Mens JMA, et al. NHG-Standaard Lumbosacraal Radiculair Syndroom. Huisarts Wet 1996;39:78-89.

119. Assendelft WJJ, Rikken SAJJ, Mel M, et al. NHG-Standaard Epicondylitis. Huisarts Wet. 1997;40:21-26.

120. Geijer RMM, van Schayck CP, van Weel, et al. NHG-Standaard COPD: behandeling. Huisarts Wet 1997:40:430-442.

121. Geijer RMM, van Hensbergen W, Bottema BJAM, et al. NHG-Standaard Astma bij Volwassenen: behandeling. Huisarts Wet 1997;40:443-454.

122. Dirksen WI. Geijer RMM, de Haan M, et al. NHG-Standaard Astma beij Kinderen. Huisarts Wet 1998:41:130-143.

123. van der Plas CG, Dingjan RA, Hamel A, et al. NHG-Standaard Traumatische Knieproblemen. Huisarts Wet 1998:41:296-300.

124. Cirkel JW, Klaassen WRC, Kunst JA, et al, NHG-Standaard. Niet-traumatische Knieproblemen bij Kinderen en. Adolescenten. Huisarts Wet 1998;41:246-251.

125. Elders P, van Keimpema JC. Petri H, et al. NHG-Standaard Osteoporose. Huisarts Wet 1999:42:115-128.

126. Chel VGM, Germs PH, van der Wal J, et al. NHG-Siandaard Decubitus. Huișarts Wet 1999;42:165-172.

127. Winters JC, Jongh AC, van der Windt DAWM, et al. NHG-Standaard Schouderklachten. Huisarts wet 1999;42:222-231،

128. Faas A. Exercises: which one's are worth trying, for which patients and when? Spine 1996;21: 28742878.

129. Bigos S, Bowyer O, Braen G, et al. Acute low back problems in adults. Clinical Practice Guideline no. 14. AHCPR Publication no. 95-0642. Rockville, MD: Agency for Health Care Policy and Research, Public Health Services, U.S. Department of Health and Human Services, 1995.

130. Waddell G. The back pain revolution. Edinburgh; Churchill Livingstone, 1998.

131. Royal Cotlege of General Practitioners (RCGP). Clinical guidelines for the management of acute low back pain. London: RCGP, 1996.

132. Oostendorp RAB, Wams HWA, Hendriks HJM. Fysiotherapie en lage-rugpijn. Een nieuw paradigma. Ned Tijdschr Fysiother 1997;107:102-110. 
133. World Health Organization (WHO). ICIDH, International Classification of Impairments, Disabilities, and Handicaps: a manual of classification relating to the consequences of disease. Geneva: WHO, 1980.

134. Kankaanpaa M. Lumbar muscle endurance in the assessment of physical performance capacity of low back pain patients [PhD thesis]. Kuopio: Kuopio University Publications, 1999.

135. Kankaanpaa M, Taimela S, Airaksinen $O$, Hanninen $O$. The efficacy of active rehabilitation in chronic low back pain. Spine (in press).

136. Heerkens YF, van den Heuvel J, van Klaveren AAJ, van Ravensberg CD. Ontwerp Classificatie Medische Termen (CMT) voor Paramedische Beroepen. Amersfoort: Nederlands Paramedisch Instituut (NPi), 1998.

137. Roebroeck ME, Dekker J, Oostendorp RAB, Bosveld W. Physiotherapy for patients with lateral ankle sprains. A prospective survey of practice parterns in Dutch Primary health care. Physiotherapy $1998 ; 84: 421-432$.

138. van Baar ME, Dekker J, Bosveld W. A survey of physical therapy goals and interventions for patients with back an knee pain. Phys Ther 1998;78:33-42.

139. van der Net J, Prakken AJB, Helders PJ. Correlates of disablement in polyarticular juvenile chronic arthritis; A cross-sectional study. Brit J Rheumatol 1996;35:91-100.

140. de Bie RA, de Vet HCW, Lenssen T. The prognosis of ankle sprains. Int J Sports Med 1997;18:285-289.

141. Lawrence RH, Jette AM. Disentangling the disablement process. J Gerontol B Psychol Sci Soc Sci 1996;51:S173-82.

142. Anke AG, Stanghelle JK, Finset A, et al. Long-term prevalence of impairments and disabilities after trauma. J Trauma 1997:42:54-61.

143. Verbrugge LM, Gruber Baldini AL. Fozard JL. Age differences and age changes in activities: Baltimore longitudinal study of Aging. J Gerontol B Psychol Sci Soc Sci 1996:5 I:\$30-4I.

144. Chiel HJ, Beer RD. The Brain has a body: Adaptive behavior emerges from interactions of nervous sytem, body and environment. Trens Neurosci 1997;20:553-557.

145. Watkinson A, Gargan MF, Bannister GC. Prognostic factors in soft tissue injuries of the cervical spine. Injury 1991;22:307-309.

146. Barnsley L. Lord S, Bogduk N. Clinical review whiplash injury. Pain; 1994;58:283-307.

147. Spitzer WO, Skovron ML, Rachid Salmi, et al. Scientific monograph of the Quebec Task Force on whiplash associated disorders: redefining 'whiplash' and its management. Spine 1995;20: no. 8s.

148. Verhagen AP, Sijpkes P, de Vet HCW. Behandeling van whiplash: een systematische review. Ned Tijdschr Fysiother 1996;106:135-141.

149. Verhagen AP, Sijpkes P, de Vet. Prognose van whiplash: een literatuuronderzoek. Ned Tijdschr Fysiother 1996; 106:142-148.

150. Stovner $L$. The nosologic status of the whiplash syndrome: a critical review based on a methodological approach. Spine 1996:21:2735-2746.

151. Nordin M. Education and return to work. In: Gunzberg R, Szpalski M (eds). Whiplash injuries: current concepts in prevention, diagnosis and treatment of the cervical whiplash syndrome. Philadelphia/New York: Lippincot-Raven Publishers, 1998.

152. Gargan M, Bannister G, Main C, et al. The behavioral response to whiplash injury. J Bone Joint Surg (Br) 1997:79B:523-526.

153. O'Rahilly R, Muller F. The embryonic human brain. New York: Wiley-Liss, 1994.

154. Snijders CJ, Nordin $M$, Frankel VH. Biomechanica van het spier-skeletstelsel: grondslagen en toepassingen. Utrecht: Lemma, 1995.

155. Bernards JA, Bouwman LN. Fysiologie van de mens. Houten/Zaventem: Bohn Siafleu Van Loghum, 1994

156. Culav EM. Connective tissues: matrix composition and its relevance to physical therapy. Phys Ther 1999;79:308-319.

157. McDonough SM. The neurophysiological basis of reciprocal inhibition in man. Phys. Ther. rev. 1997:2:19-28.

158. Cushway D. Understanding stress and coping. Br J Ther Rehabil 1995;2:615-620

159. Vlaeyen JWS, Kole-Snijders AMJ, Boeren RGB, van Eek H. Fear of movement / (re)injury in chronic low back pain and its relation to behavioral performance. Pain 1995;62:363-372. 
160. Vlaeyen JWS. Chronic low back pain. assessment and treatment from a behavioral rehabilitation perspective (PhD thesis), Maastricht: Maastricht University, 1991.

161. Kiecolt-Glaser JK, Marucha PT, Malarkey WB, Mercado AM, Glaser R. Slowing of wound healing by psychological stress. Lancet 1995;346:1194-96.

162. Kiecolt-Glaser JK, Glaser R. Psychoneuroimmunology and health consequences: data and shared mechanisms. Psychosomat Med 1995;57:269-274.

163. van Wingerden BAM. Connective tissue in rehabilitation. Vaduz, Liechtenstein: Scipro Verlag, 1995

164. Smits-Engelsman BCM. Theory-based diagnosis of the fine-motor coordination development and deficiencies using handwriting tasks (PhD thesis). Nijmegen: NICI, 1995.

165. Mulder Th. A process-oriented model of human motor behavior. Toward a theory-based rehabilitation approach. Phys. Ther 1991;71:157-164.

166. Jette AM, Delitto A. Physical therapy treatment choices for musculoskeletal impairments. Phys Ther 1997;77:145-154.

167. Mielenz TJ, Carey TS, Dyrek DA, et al. Physical therapy utilization by patients with acute low back pain. Phys Ther 1997;77:1040-1051.

168. van Ravensberg CD, Wams HWA, Oostendorp RAB, Zicht op fysiotherapie: prognose aantal behandelsessies gekoppeld aan doelstellingen en resultaten na 9 sessies. Amersfoort: Nederlands Paramedisch Instituut (NPi), 1996.

169. Roebroeck ME, Hutten JBF, Kerssens JJ, Dekker J. De omvang van de fysiotherapeutische behandeling naar verschillende patiëntencategorieën. Utrecht: Nederlands instituut voor onderzoek van de gezondheidszorg (Nivel), 1995.

170. van Ravensberg CD, van Klaveren AAJ, Wams HWA, et al. Variabelen in samenhang met aantal behandelingen fysiotherapie: analyse FON-PPP-gegevens. Amersfoort: Nederlands Paramedisch Instituut (NPi), 1995.

171. Zuijderduijn W, Dekker J, Abrahamse H. Determinanten van de omvang van behandeling in de extramurale fysiotherapie. Tijdschr Soc Gezondheidsz 1995;75:274-281.

172. van Klaveren AA, van Ravensberg CD, Oostendorp RAB, Hendriks HJM, Elvers JWH. Basisregistratie Fysiotherapie. Een inventarisatie van het fysiotherapeutisch handelen in de eerste lijn. Amersfoort: Nederlands Paramedisch Instituut (NPi), 1995.

173. Yoshida KK, Allison KR. Sociodemographic and health-related characteristics of Ontarians making contact with physical therapists: analysis of the 1990 Ontario health survey. Physiotherapy Canada 1997;49:214221 .

174. Roach KE, Ally D, Finnerty B, et al. The relationship between duration of physical therapy services in the acute care setting and change in functional status in patients with lower-extremity orthopedic problems. Phys Ther 1998;78:19-24.

175. Fordyce WE. Behavioural methods for chronic pain and iliness. St. Louis: CV Mosby, 1976.

176. Lindström I, Ohlund C, Eek C, et al. The effect of graded activity on patients with subacute pain: a randomized prospectieve clinical study with an operant behavioural approach. Phys Ther 1992;72:279290.

177. Edwards BC. A physical approach to the rehabilitation of patients with chronic low back pain. Med J Australia 1992;156:168-171.

178. Frost H. Randomised controlled trial for evaluation of fitness programme for patients with chronic low back pain. BMJ 1995;310:151-154.

179. Heerkens $\mathrm{Y}$, van den Heuvel H, van Klaveren $T$, van Ravensberg CD. Voorlopige Classificatie Verrichtingen Paramedische Beroepen. Amersfoort: Nederlands Paramedisch Instituut (NPi), 1995.

180. Beurskens AJHM, de Vet HCW, Koke AJA, et al. Efficacy of traction for non-specific low back pain; 5-week results of a rondomized clinical trial. Lancet 1995;346:1596-1616.

181. Gadsby JG, Flowerdew MW. The effectiveness of transcutaneous electrical nerve stimulation (TENS) and acupuncture-like transcutaneous elecrical nerve stimulation (ALTENS) in the treatment of patients with chronic low back pain. The Cochrane Library 1999 Issue 1, pp. 1-35.

182. Lacasse Y, Wong E, Guyatt GH, et al. Meta-analysis of respiratory rehabilitation in chronic obstructive pulmonary disease. Lancet 1996;348:1115-1119.

183. American Thoracic Society (ATS). Standards for the diagnosis and care of patients with chronic obstructive pulmonary disease. ATS statement. Am J respir Crit Care Med 1995:152:S77-S120. 
184. Urinary Incontinence Guidelines Panel. Urinary incontinence in adults: clinical practice guideline. AHCPR pub. no. 92-0038. Agency for Health Care Policy and Research, Public Health Service, US Department of health and Human services, Rockville, MD, 1992.

185. Berghmans L.CM, Bernards ATM, Hendriks HJM, Bo K, Grupping MHM. Guidelines for the physiotherapeutic management of genuine stress incontinence. Phys. Ther. Rev. 1998:3:133-147.

186. Berghmans LCM, Bernards ATM, Bluyssen AMWL, et al. KNGF-richtlijn Stress-incontinentie. Ned Tijdschr Fysiother 1998:108: supplement no. 2.

187. Bo K. Physiotherapy to treat genuine stress incontinence, Int Cont Surv 1996;2-8.

188. Robeer GG, Brandsma JW, van den Heuvel S, et al. Exereise therapy for intermittent claudication; a review of the quality of randomized clinical trials and evaluation of predictive factors. Eur J Vasc Endovasc Surg 1998;15:36-43.

189. Gardner AW, Pochlman ET. Exercise rehabilitation programs for the treatment of claudication pain. JAMA 1995:274:975-80.

190. Hochberg MC, Altman RD, Brandt KD, et al. Guidelines for the medical management of osteoarthritis. Part I. Osteoarthritis of the hip. Arthritis Rheum 1995:38:1535-1540.

191. Hochberg MC, Altman RD, Brandt KD, et al. Guidelines for the medical management of osteoarthritis. Part II. Osteoarthritis of the knee. Arthritis Rheum 1995;38:1541-1546.

192. van Baar M. Effectiveness of exereise therapy in osteoarthritis of the hip or knee [PhD Thesis]. Utrecht: Nederlands Instituut voor onderzock van de gezondheidszorg (Nivel), 1998.

193. de Bie RA, Hendriks HJM, Lenssen AF, et al. KNGF-richtlijn Acuut Enkelletsel. Ned Tijdschr Fysiother 1998;108: supplement no. 1.

194. Oostendorp RAB, Functionele Vertebrobasilaire Insufficiêntie [PhD thesis]. Nijmegen: Katholieke Universiteit Nijmegen (KUN), 1988.

195. Fujino A, Tokumasu K, Yosio S, et al. Vestibular training of benign paroxysmal positonal vertigo. Its efficacy in comparison with anivertigo drugs. Arch Otolaryngol Head Neck Surgery 1994;120:497-504.

196. Yardley L, Beech S, Zander L, Evans T, Weinman J. A randomized controlled trial of exercise therapy for dizziness and vertigo in primary care. Br J Gen Pract 1998;48;1136-1140.

197. Nieuwboer A, de Weerd W, Nuyens G, et al. Fysiotherapie en Parkinson: een review van de literatuur. Ned Tijdschr Fysiother. 1994:104:122-128.

198. Noteboom T, Cruver R, keller J, Kellogg B, Nitz AJ. Tennis elbow: a review. JOSPT 1994;19: 357-366.

199. Hendriks HJM, Kerssens JJ, Bekkering GE, et al. Patterns of utilization and efficiency of care of physiotherapist consultation in general parctice. Physiother Theory Prac (accepted).

200. Oostendorp RAB, van Eupen AAJM, Elvers JWH, van Erp JMM. Physical therapy and the consequences of whiplash injury. In: proceedings of the 12th International Congress of the World Confederation for Physical Therapy, June 25-30. Washington DC, USA, 1995.

201. Bury T. The status and development of physiotherapy research in the United Kingdom. Phys. Ther, Rev. 1997:2:165-171.

202. Pincus T: Assessing psychological factors in chronic pain - a new approach. Phys. Ther. Rev, 1998; 3:41-45.

203. Sluijs EM, van der Zee J, Kok GJ. Differences between physical therapists in attention paid to patient education. Physiother Theory Practice 1992;9:103-117.

204. Sluijs EM, Kerssens JJ, vas der Zee J. Adherence to physiotherapy. In: Myers L. Midence K (eds). Adherence to medical treatment. Reading, England: Harwood Academic Publishers, 1998.

205. Kerssens JJ, Sluijs WM, Verhaak PFM, Knibbe HJJ, Hermans IMJ. Back care instructions in physical therapy: a trend analysis of individualized back care programs. Phys Ther 1999;79:286-295.

206. Kassirer JP. Incorporating patients' preferences into medical decisisons. N Engl J Med 1994:330:1895. 1896.

207. Owens DK. Patient preferences and the development of practice guidelines. Spine 1998;23:1073-1079.

208. Hernberger JC, Habracken MA, Bloch DA. Minimun data needed on patient preferences for accurate efficient decision making. Medical Care $1995 ; 33: 297-310$.

209. Verhulst FJCM, van der Burgt MCA, Lindner $\mathrm{K}$. Concretisering van patiëntenvoorlichting in het fysiotherapeutisch handelen. Ned Tijdschr Fysiother 1994;104:10-17.

210. Battié MC, Cherkin DC, Dunn R et al. Managing, low back pain: attitudes and treatment preferences of physical therapists. Phys Ther 1994;74:101-115. 
2i1. Fung $\mathrm{S}, \mathrm{Byl} \mathrm{N}$, Melnick M, et al. Functional outcomes: the development of a new instrument to monitor the effectiveness of physiotherapy. European Journal of Medical Rehabilitation 1997;7:31-41. 


\section{Consultation between General Practitioners and Medical Consultants in the Dutch health care system. What can we learn from the literature?}

\section{Abstract}

Complexity and specialisation of medical care increases and as a consequence the general practitioner's role in the provision of optimal continuing care grows in importance, but is at the same time more challenged by the full set of encountered biomedical, psychosocial, and behavioral health problems. The implementation of consultation models is hypothesized as an interesting strategy to support the general practitioner (GP) in clinical practice and to improve their relationship with other health care providers.

Twenty-seven studies including five different types of consultation models were identified by a computer-aided and manual search. All but 3 of the 27 studies were preexperimental, 2 of the 3 being quasi-experimental and 1 true-experimental. All studies looked at the outcome on the process of care (general practioners' attitude, performance, and impact on clinical practice) and 4 examined also the patient outcomes.

The majority of the 27 studies showed beneficial effects in a broad range of outcome measurements on the process of care: continuing education (17 studies), communication (6 studies), cooperation (8 studies), continuity of care, clinical management and/or (lower) referral rates (22 studies). Four studies demonstrated positive changes in patients' clinical status. Overall, the GPs (4 studies) and their patients (5 studies) were satisfied with the process of care and the outcomes of the procedures of consultation models utilized in practice.

Although the results of the review suggest beneficial effects on both the process of care and clinical outcome, there is no convincing evidence that any type of consultation leads to clinical benefits and changes of GPs' process of care (behaviour). More rigorous studies are needed to evaluate the effectiveness of consultation in a variety of settings, providers, patients, and health problems.

Submitted as:

Hendriks HJM, van der Zee J. de Bie RA, Pop P.

Consultation between general practitioners and medical consuftants in the Dutch health care system. What can we learn from the literature? (submitted) 


\section{Introduction}

Current emphasis on cost-effectiveness, continuity of care and patient-oriented care, calls for changes in the health care system in The Netherlands ${ }^{14}$ as well as in many other countries. ${ }^{5.6}$ These changes brought on by health care reform ${ }^{7.9}$ focus on: (1) the family physician (or general practitioner [GP']) as the primary provider and gatekeeper of health services based on a growing awareness that referral to medical specialists is not always necessary; ${ }^{10,11}$ (2) the recognition of the influence of the psychosomatic component on physical functioning (the biopsychosocial view of the patient and his/her illness); ${ }^{12}$ and (3) the ability to provide a greater proportion of health care in a community setting. ${ }^{3,4,13,14}$ These opposing trends require a flexible, well-structured and organized system of collaborating primary health care services with more emphasis on interdisciplinary communication about patients and about joint care.

The question of how GPs, when in doubt, might consult medical specialists or other health care providers has long been of interest to clinicians and health service planners alike. ${ }^{10,15}$ This article reviews the research literature on the nature and effectiveness of referrals and consultations between GPs and medical specialists in The Netherlands in order to optimize patient care.

In The Netherlands 7,450 practicing GPs had, on average, 2,300 registered patients per GP. ${ }^{16,17}$ Nearly half of them were single-doctor practices. ${ }^{17}$ In 1999 the total cost of general practice was approximately 2,3 billion guilders ( $4 \%$ of the total cost of health care). ${ }^{17}$ Ninety-eight percent of the Dutch population is registered with a GP. Health surveys from the Central Bureau of Statistics (CBS) show that each year 70-75 percent of patients have at least one contact with their GP. ${ }^{17}$ In 6 percent of the total number of patient contacts a patient was referred to other health care providers. Set against the total number of registered patients per practice, $28 \%$ was referred.

The services performed by the GP are characterised by diversity and pluralism on the one hand, and by a high degree of commonality on the other. The central position of the GP in the provision of primary health care services in The Netherlands highlights the responsibility for personal, comprehensive, continuous, and coordinated medical care. Since most health care services are accessible through a written referral from the GP, this central position implies that to ensure optimal patient care GPs must be highly skilled in referring patients adequately to other health professionals.

However, medical care becomes more specialised and complex and as a consequence the GP's role becomes more important and also more challenged by the full set of encountered biomedical, psychosocial, and behavioural health problems. Doubts about the indication for and appropriateness of referral is illustrated by large variations both within and among GPs in the number of referrals to medical specialists. ${ }^{10.11 .15,18-26}$ 
The differences in consultation and referral rates stress the need to determine the indication for referral precisely, to provide individually-tailored care, to protect patients from unnecessary diagnostic procedures and from other unnecessary medical interventions, and thus control the costs of health care.

Although the literature provides a fairly comprehensive account of the extent of variation in referral rates, it is less complete in addressing the problem of identifying the source of this variation. ${ }^{10.11 .15}$,18-25 Factors identified from the literature that may affect GPs' decision on referral were grouped in four blocks of variables which impinged on referral decisions: professional attributes, knowledge of the health care system, personal style, and patient related factors. ${ }^{10,18.20 .26}$

If the GP feels uncertain and doubts the appropriateness of referral, the consultation model of interaction with other health professionals could assist the GP in his or her management plan and indication setting. Indication setting is defined as the determination of the kind of care required, the care provider, expertise, and equipment best suited to the needs of the patient. ${ }^{27}$

Epidemiological studies describe the GPs' need for professional advice in cases of uncertainty about diagnosis or treatment without losing continuity of patient care. . $^{10.20,26-}$ ${ }^{29}$ These studies also demonstrate more awareness by GPs of the advantages of consultation and of activities to ensure cooperation and a multidisciplinary approach to clinical problems.

The effectiveness of consultation between GPs and medical specialists or other health care providers has not yet been well established. It is hypothesized that the implementation of a consultative approach might lead to better patient outcomes and more efficient health care utilization through improved communication and cooperation between GPs and medical specialists or other health professionals.

The purpose of this literature review spanning the last two decades is to evaluate the effects of different models of consultation in the Dutch health care sytem on: (1) the process of care (e.g. performance, impact on medical education and management plan [e.g. continuity of care, referral pattern]), (2) patient outcome, and (3) satisfaction with the process of consultation.

This paper will addresses the following questions:

1. Which models of consultation between GPs and medical specialists or other health care providers in the Dutch health care sytem are available to GPs at present?

2. How effective are the models of consultation / activities in terms of (1) improved patient outcomes and satisfaction and of (2) GPs performance (behaviour), and management plan, and satisfaction with the process and outcome of the consultation?

3. What are the prerequisites or barriers for the succesful implementation of models of consultation used in practice? 


\section{Methods}

\section{Data sources}

Consultation is defined as a request by the GP for an opinion from the consultant(s), while referral is the transfer of responsibility to another health professional. A broad search of computerized bibliographic databases from 1980 to 2000, was undertaken. Medline, the Cumulated Index to Nursing and Allied Health (CINAHL: from 1982), the database of the Dutch National Institute of Allied Health Professions and the Nivel databases "Health Care Innovation" and "Research in Primary Health Care (RWO)" were searched for articles documenting the outcome of original research in the Dutch health care system. Study types included pre-, quasi- and true-experimental designs. Key words characterizing the design were: outcome study, observational study, longitudinal study, before-and-after or evaluation study, pretest-posttest, randomised controlled clinical trial and effectiveness. Key words representing the intervention were: consultation, consultative care, joint consultation, consultative referral, consultation meetings and consultation-liaison. Key words defining the health care professionals were: general practitioner, primary care physician, and primary care. Additional key words used were: communication, cooperation, education, experiences, satisfaction, referral pattern and clinical status. Citation tracking of relevant articles was performed. In addition abstracts presented at national meetings (Dutch Society of General Practitioners [NHG]) were searched. Because the concept 'consultation' as defined in the methods section is not always used, the four most relevant Dutch journals (Medisch Contact, Huisarts en Wetenschap, Tijdschrift voor Gezondheidswetenschappen (TSG) en het Nederlands Tijdschrift voor Geneeskunde) were searched manually over the same time interval (1980-1999).

\section{Selection of articles}

To determine the effecis of the consultation models on the process of care (defined as changes in GPs' performance [behaviour], attitude, education, cooperation, communication and management plan [e.g. referral patterns and continuity of care]) or the outcome on clinical status for their patients, articles were selected if they studied some type of consultation initiated by GPs or designed to assist GPs in their management plans and if they presented qualitative or quantitative data about groups of patients. Only reports of studies conducted in the Dutch health care system were included in the review. Each article collected data on the types of providers (GPs and consultants), patients, types of the consultation models of interaction, and outcome measures. 


\section{Analysis}

Both quantitative and qualitative data of the effects of consultation on the process of care and patient outcome were extracted and tabulated. Although the included studies reported multiple outcome measurements, we examined only the primary measures of effect for each study.

\section{Results}

The literature search yielded 126 publications, of which 12 were abstracts. Most of the articles (76 studies) were excluded from further analysis because they reported theoretical perspectives only, or the intervention did not meet the definition of consultation as defined in the methods section. The number of potentially eligible articles was reduced to 48 studies. Eleven articles were excluded because the different types of consultation models of interaction were not initiated by the GP (4 studies) or the intervention did not meet the selection criteria to be included in this review (7 studies). Twelve projects registered in the Nivel database "Research in Primary Health Care (RWO)" were still ongoing or no reports were available at all. If several articles were published from the same study, information and/or results were combined.

A total of 27 studies that studied the effects of some form of consultation were judged as being relevant enough to be included for further analysis. ${ }^{30-65}$ Twenty-four studies were pre-experimental, ${ }^{30-40,46-65}$ two were quasi-experimental ${ }^{44,45}$ and one was a true-experimental trial. ${ }^{4-43}$ Although the pre-experimental studies lacked an experimental control group we decided to include these studies in this review.

All studies analyzed the effects on the process of care defined as the GP's effect on performance, attitude, education, communication, cooperation and on their management policy (continuity of care). Four studies analyzed the effects on patient's clinical outcome. ${ }^{37.38 .39 .41-43.45}$ The included studies examined the effects of consultation between GPs and one of the following medical specialists: internists ( 3 studies), ${ }^{30-32}$ geriatricians or nursing home physicians $\left(6\right.$ studies), ${ }^{33-40}$ orthopedic surgeons (1 RCT), ${ }^{4 / 43}$ psychiatrists/mental health professions ( 3 studies), ${ }^{44-47}$ gynaecologists/ obstetricians ( 3 studies), ${ }^{48.50}$ pediatricians (2 studies), ${ }^{54.55 .65}$ medical diagnostic centers ( 3 studies) ${ }^{31,51 .}$ 56.57 and oncologists (1 study). ${ }^{52}$ Three studies examined the outcome of consultation models between GPS and other medical specialisms. ${ }^{33.57}$ Five studies examined the effects of consultation ${ }^{33-35.61 .63,64}$ and/or peer review among GPs. ${ }^{58-60}$ Three of the five studies examined the outcome of consultation by telephone with a trained GP for patients with AIDS ${ }^{61}$ or for GPs wanting to discuss euthanasia. ${ }^{63.64}$

Table 1 summarizes each of the included studies, giving a brief description of the participants (consultants), type of the consultation model, patients, design, and outcome measurements. The studies are grouped by types of medical consultants and year of publication. 


\section{Types of consultation}

The consultation models studied were: referral for (a one-time) consultation (12 studies); ${ }^{33-40,45-48,51,56,57,65}$ consultation by telephone (8 studies); ${ }^{31.32,51.56,57,61-64}$ joint consultation (5 studies), ${ }^{41-43,48-50,53}$ regular consultation meetings (3 studies) ${ }^{30,44,54,55}$ and peer review by colleagues ( 1 study). ${ }^{58-60}$

In a referral for (a one-time) consultation, the patient is referred by means of a standardized consultation request form for a single examination. The consultation request may refer to diagnosis and/or treatment options by the medical specialist concerned. Following the examination, the consuitant reports findings and advice(s) to the consuitant by telephone and in writing. It is then possible to arrange a case discussion based on the report. In the literature, the results of consultation referrals by the GP to nursing home physicians [geriatric team], ${ }^{33-40}$ psychiatrists, ${ }^{44-47}$ medical diagnostic centres, ${ }^{31.51}$ paediatricians ${ }^{6.5}$ and to gynaecologists ${ }^{48}$ are described. In one project, the opportunity to make a preventive: referral to a consultation bureau for the elderly is described. ${ }^{37,38}$ Braak et al ${ }^{34,35}$ describes a project in which the GP, following consultation by telephone with a GP coordinator, refers the patient to the GP coordinator by means of a standard letter of referral. The coordinator then chooses the relevant specialist in relation to the problems of the patient concerned. In the Diagnostic Centre Maastricht, GPs are able to make continuous use of the Centre's diagnostic facilities. ${ }^{31,32,56,57}$

Consultation by telephone means that the consultant, based on information held by the $\mathrm{GP}$, offers an opinion without having personally seen the patient. The consultation is concluded by a written report from the consultant. A consultation by telephone is less time-consuming than other forms of consultation.

At a joint consultative examination, the patient is examined jointly by the consultant and the consultee. Prior to the examination, a registration form comprising a clearlydefined consultation request and medical background data is filled in.

The consultation meeting is a formal and frequent meeting between GPs and specialists. The participating specialism varies per project. Known projects comprise a paediatrician and an ear, nose and throat specialist, ${ }^{54.55}$ an internist, ${ }^{30}$ and a psychiatric team. ${ }^{44}$ Meetings were held at intervals of two to four weeks, or five to six weeks. The duration of the projects varied between one and four years. At a consultation meeting, a specific case is examined from different angles, and advice and recommendations are directly given to the consultee.

By peer review we mean a consultation among peers about the diagnosis and management of specific cases. The consultation is characterized by (1) the definition of the actual problem and of the diagnostic process, (2) the methods of evaluation, (3) the pro's and con's of various management decisions, (4) the inclusion of the wider spectrum of problems, and (5) the follow-up consultation about the same and / or other problems after a certain interval. ${ }^{58-60}$ 


\section{Effects on the process of care}

Overall, the results of the studies indicate that the different types of consultation models have a beneficial impact on the process of care and that they meet the needs of GPs. However, the number of consultations, outcome measurements, and the extent of benefits vary considerably.

Management policy and continuity of care. All studies, except five $(n=22), 52.58-61,03,04$ focus on the effects of consultation on GPs' management policy $(n=4)$ or continuity of care $(n=18)$. Eighteen of the 22 studies ${ }^{30,35,39,41-43,45,49-52,4457,65}$ show substantial changes in GP's diagnostic - therapeutic actions and/or referral patterns. The number of referrals to medical specialists was, reduced in 17 studies by explicit use being made of the consultant's knowledge, ${ }^{30-35,39,41-43,45,49 \cdot 50.4457 .65}$ Six studies fail to demonstrate quantitative changes in GP's management policy or the results were inconclusive. ${ }^{37}$ $39,40,44,46,47.52$ Nine studies suggest that consultation is a substitute for treatment referrals to medical specialists. ${ }^{31}, 33-35,41-43,48 \cdot 50,53,65$ A causal relationship was difficult to prove due to the research design chosen for the majority of the studies. The solitary RCT, however, showed that the number of referrals to medical specialists in the joint consulation group was significantly lower than in the usual care group. ${ }^{41-43}$ Vierhout et al ${ }^{41,42}$ studied the effectiveness of joint consultation sessions by GPs and orthopedic surgeons in cases of musculoskeletal disorders. The number of referrals to specialists was reduced by more than half. Vierhout et al ${ }^{41.42}$. also showed that the total number of diagnostic and/or therapeutic actions by the GP in the case of a particular complaint is considerably lower in the experimental group using joint consultation than it is in the control group. Consultation also strengthens the GP's role in the provision of appropriate primary and continuity of care. ${ }^{4143}$

Cooperation and communication. Eight and six studies respectively, showed considerable improvement in cooperation ${ }^{31,41-43,50-57}$ or communication ${ }^{30-32,45,50,51}$ with consultants. In addition, Bensing et al, ${ }^{44}$ Pop, ${ }^{31}$ and Pop and Kerkhof ${ }^{32}$ show that consultation clarifies the indication to refer, and that referrals by the GP to a specialism therefore improve. The randomized controlled study also demonstrate that intensifying cooperation between health workers will positively influence the effectiveness and efficiency of primary care provided by the GP. ${ }^{41-43}$

Continuing education. Seventeen studies were available that suggested consultation results in continuous education and improvement of skills with respect to certain patient-problems. ${ }^{30-32,40-43,48-50,52-57,61-65}$ More efficient use of specific expertise can prevent unnecessary (and undesirable) use of medical care (medicalisation) ${ }^{39.40,44}$ and thus will lead to more appropriate use of the available health-care services..$^{30-33.41-43.48-51}$ Appropriate and efficient use of certain diagnostic facilities was enhanced during the consultation projects. ${ }^{30.32 .51 .56 .57}$.

Other findings. Six pre- or quasi-experimental studies reported that the consultation had resulted in referring patients who would otherwise not have been referred to medical specialists. ${ }^{44,47,52,54,55,65}$ The characteristics of those patients referred for consultations were different from those receiving usual care. 
Table 1. Brief details of the studies included

\begin{tabular}{|c|c|c|c|c|}
\hline $\begin{array}{l}\text { Authors } \\
\text { Year }\end{array}$ & $\begin{array}{l}\text { Study Design } \\
\text { (duration) }\end{array}$ & $\begin{array}{l}\text { Consultation! } \\
\text { model }\end{array}$ & $\begin{array}{l}\text { Participants } \\
\text { Providers }\end{array}$ & $\begin{array}{c}\text { Patients } \\
\text { (No. and complaints) }\end{array}$ \\
\hline \multicolumn{5}{|l|}{ Internists } \\
\hline $\begin{array}{l}\text { Grinten } \\
1981\end{array}$ & $\begin{array}{l}\text { Pre-Exp. } \\
\text { (48 months) }\end{array}$ & $\begin{array}{l}\text { Consultation } \\
\text { Meeting }\end{array}$ & $\begin{array}{l}4 \text { GPs } \\
1 \text { Internist }\end{array}$ & $\begin{array}{l}235 \\
\text { Internal complaints }\end{array}$ \\
\hline $\begin{array}{l}\text { Pop } 31 \\
1982\end{array}$ & $\begin{array}{l}\text { Pre-Exp. } \\
\text { ( } 35 \text { months) }\end{array}$ & $\begin{array}{l}\text { Consultation by } \\
\text { telephone }\end{array}$ & $\begin{array}{l}67 \text { GPs } \\
1 \text { Internist }\end{array}$ & $\begin{array}{l}250 \\
\text { Internal complaints }\end{array}$ \\
\hline $\begin{array}{l}\text { Pop "11 } \\
1982 \& 1984\end{array}$ & $\begin{array}{l}\text { Pre-Exp. } \\
\text { (48 months) }\end{array}$ & $\begin{array}{l}\text { Consultation by } \\
\text { telephone }\end{array}$ & $\begin{array}{l}50 \text { GPs } \\
1 \text { Internist }\end{array}$ & $\begin{array}{l}318 \\
\text { Internal complaints }\end{array}$ \\
\hline
\end{tabular}

Geriatricians / nursing home physicians

\begin{tabular}{|c|c|c|c|c|}
\hline $\begin{array}{l}\text { Brouwer }{ }^{21} \\
1983\end{array}$ & Pre-Exp. & $\begin{array}{l}\text { Consultative } \\
\text { referral }\end{array}$ & $\begin{array}{l}\text { GP trained in geriatric } \\
\text { problems selects MS }\end{array}$ & $\begin{array}{l}43 \\
\text { Geriatric problems }\end{array}$ \\
\hline $\begin{array}{l}\text { Braak sus } \\
1989 \& 1993\end{array}$ & $\begin{array}{l}\text { Pre-Exp. } \\
\text { (26 months) }\end{array}$ & $\begin{array}{l}\text { Consultative } \\
\text { referral }\end{array}$ & $\begin{array}{l}\text { GP trained in geriatric } \\
\text { problems selects MS }\end{array}$ & $\begin{array}{l}170 \\
\text { Somatic- and } \\
\text { Psychogeriatric } \\
\text { problems }\end{array}$ \\
\hline $\begin{array}{l}\text { Fockent } \\
1985\end{array}$ & $\begin{array}{l}\text { Pre-Exp. } \\
\text { (12 months) }\end{array}$ & $\begin{array}{l}\text { Consultative } \\
\text { referral }\end{array}$ & $\begin{array}{l}\text { GPs } \\
\text { Nursing home physician } \\
\text { psycho-getiatrist }\end{array}$ & $\begin{array}{l}100 \\
\text { Geriatric problems }\end{array}$ \\
\hline $\begin{array}{l}\text { Wersch } 17.4 \\
1987 \& 1990\end{array}$ & $\begin{array}{l}\text { Pre-Exp. } \\
(24 \text { months) }\end{array}$ & $\begin{array}{l}\text { Consultative } \\
\text { referral }\end{array}$ & $\begin{array}{l}35 \text { GPs } \\
\text { Nursing home physician }\end{array}$ & $\begin{array}{l}206 . \\
\text { Geriatric problems }\end{array}$ \\
\hline $\begin{array}{l}\text { Willemse }{ }^{n} \\
1989\end{array}$ & $\begin{array}{l}\text { Pre-Exp. } \\
\text { (12 months) }\end{array}$ & $\begin{array}{l}\text { Consultative } \\
\text { referral }\end{array}$ & $\begin{array}{l}\text { GPs } \\
\text { Nursing home physician } \\
\text { [psychologist, nurse, social } \\
\text { worker] }\end{array}$ & $\begin{array}{l}113 \\
\text { Geriatric problems }\end{array}$ \\
\hline $\begin{array}{l}\text { Collijn } \\
1994\end{array}$ & $\begin{array}{l}\text { Pre-Exp. } \\
\text { (6 months) }\end{array}$ & $\begin{array}{l}\text { Consultative } \\
\text { referral }\end{array}$ & $\begin{array}{l}25 \text { GPs } \\
\text { Nursing home physician }\end{array}$ & $\begin{array}{l}32 \\
\text { Complex problems }\end{array}$ \\
\hline
\end{tabular}

Orthopedic surgeons

$\begin{array}{lllll}\text { Vierhout }{ }^{\text {ti.d }} & \text { True-exp. } & \text { Joint } & 12 \mathrm{GPs} & 144 \text { vs } 128 \\ 1995 & \begin{array}{l}\text { (18 months; one } \\ \left.\text { (Ooij }{ }^{4}\right)\end{array} & \text { consultations } & 4 \text { Orthopedic surgeons } & \begin{array}{l}\text { Musculoskeletal } \\ \text { disorders }\end{array}\end{array}$

\begin{tabular}{|c|c|c|c|c|}
\hline \multicolumn{5}{|c|}{ Psychiatrists / mental health professionals } \\
\hline $\begin{array}{l}\text { Bensing * } \\
1980\end{array}$ & $\begin{array}{l}\text { Quasi-Exp. } \\
\text { (15 months) }\end{array}$ & $\begin{array}{l}\text { Consultation } \\
\text { meetings. }\end{array}$ & $\begin{array}{l}6 \text { Company physicians } \\
\text { psychiatrist, psychologist. } \\
\text { social worker }\end{array}$ & $\begin{array}{l}25 \\
\text { psychosomatic } \\
\text { complaints }\end{array}$ \\
\hline $\begin{array}{l}\text { Buis *s } \\
1990\end{array}$ & $\begin{array}{l}\text { Quasi-Exp. } \\
\text { (18 months) }\end{array}$ & $\begin{array}{l}\text { Consultative } \\
\text { referral }\end{array}$ & $\begin{array}{l}67 \text { GPs } \\
\text { Diagnostic Psychiatric } \\
\text { Advice Center }\end{array}$ & $95 \mathrm{vs} 110$ \\
\hline $\begin{array}{l}\text { Verhaak }=0 \\
1994\end{array}$ & $\begin{array}{l}\text { Pre-Exp: } \\
\text { (7 months) }\end{array}$ & $\begin{array}{l}\text { Consultative } \\
\text { referral }\end{array}$ & $\begin{array}{l}6 \text { GPs } \\
2 \text { Psychiatrists }\end{array}$ & $\begin{array}{l}45 \\
\text { psychosomatic } \\
\text { complaints }\end{array}$ \\
\hline
\end{tabular}


Effects on:

(1) process of care

Notes

(2) patient outcome

Internists

(1) positive: communication, education, continuity of care

- Improved referral policy

- Changes initial management plan

(1) positive: communication, cooperation, education, continuity of care, substitution towards primary care

- Diagnostic testing only

- Patient data can not be checked by consultant

(1) positive: communication, education, continuity of care, efficient care

- Diagnostic testing only

- Improved refernal policy

- Patient data can not be checked by consultant

Geriatricians / nursing home physicians

(1) positive: continuity of care, cooperation, substitution towards primary care

(2) patients satisfied

(1) positive: continuity of care, substitution towards primary care

(2) patients satisfied

(1) positive: continuity of care

- consultation process met the needs of GPs

- adequate recommendations

- compliani wih recommendations

(1) positive; diagnostic information, continuity of care

(2) positive effect on health problem

- no substitution effects

(1) positive: continuity of care, de-medication

(2) positive effect on functional outcome

- multiple and complex geriatric problems

(1) positive: education, continuity of care. GPs satisfied

(2) patients satisfied

- valuable diagnostic information and medication prescription

- compliant with recommendations

Orthopedic surgeons

(1) positive: education, cooperation, substitution towards primary care, continuity of care

(2) better patient outcome in experimental group. patients satisfied

- cost-effective intervention

- less diagnostic/therapeutic actions by GPs in consultation group

Psychiatrists / mental health professionals

(1) positive: improved management policy (continuity of care) and attitude to patients

(1) positive: continuity of care, communication

(2) better patient outcomes in experimental group

(1) GPs and psychiatrists satisfied

(2) Patients satisfied
- no substitution effect

- patients were different compared with usual care

- effect on medication presription and counseling

- patients were different when compared with usual care

- consultation process is feasible

- patients were different when compared with usual care 


\begin{tabular}{|c|c|c|c|c|}
\hline $\begin{array}{l}\text { Authors } \\
\text { Year }\end{array}$ & $\begin{array}{l}\text { Study Design } \\
\text { (duration) }\end{array}$ & $\begin{array}{l}\text { Consultation } \\
\text { model }\end{array}$ & $\begin{array}{l}\text { Participants } \\
\text { (Providers) }\end{array}$ & $\begin{array}{c}\text { Patients } \\
\text { (No. and complaints) }\end{array}$ \\
\hline \multicolumn{5}{|c|}{ Gynaecologists / obstetricians } \\
\hline $\begin{array}{l}\text { Hageman * } \\
1984\end{array}$ & $\begin{array}{l}\text { Pre-Exp. } \\
\text { ( } 36 \text { months) }\end{array}$ & $\begin{array}{l}\text { Joint } \\
\text { consultation or } \\
\text { referral }\end{array}$ & $\begin{array}{l}3 \text { GPs } \\
2 \text { Midwifes } \\
1 \text { Gynaecologist }\end{array}$ & $\begin{array}{l}365 \\
\text { Woman's health } \\
\text { problems }\end{array}$ \\
\hline $\begin{array}{l}\text { Hall }{ }^{*} \\
1987\end{array}$ & $\begin{array}{l}\text { Pre-Exp. } \\
\text { ( } 48 \text { months) }\end{array}$ & $\begin{array}{l}\text { Joint } \\
\text { consultation }\end{array}$ & $\begin{array}{l}\text { GPs } \\
\text { Gynaecologists }\end{array}$ & $\begin{array}{l}171 \\
\text { Woman's healthi } \\
\text { problems }\end{array}$ \\
\hline $\begin{array}{l}\text { Boer de } \\
1996\end{array}$ & $\begin{array}{l}\text { Pre-Exp, } \\
\text { (54 months) }\end{array}$ & $\begin{array}{l}\text { Joint } \\
\text { consultation }\end{array}$ & $\begin{array}{l}\text { GPs } \\
\text { Gynaecologists }\end{array}$ & $\begin{array}{l}166 \\
\text { Woman's health: } \\
\text { problems }\end{array}$ \\
\hline
\end{tabular}

Others

\begin{tabular}{|c|c|c|c|c|}
\hline $\begin{array}{l}\text { Grijn }{ }^{n} \\
1982\end{array}$ & $\begin{array}{l}\text { Pre-Exp, } \\
\text { ( } 36 \text { months) }\end{array}$ & $\begin{array}{l}\text { Consultative } \\
\text { referral or by } \\
\text { telephone }\end{array}$ & $\begin{array}{l}\text { GPs } \\
\text { Diagnostic Medical } \\
\text { Center }\end{array}$ & $\begin{array}{l}\text { Diversity of diagnostic } \\
\text { requests }\end{array}$ \\
\hline
\end{tabular}

\begin{tabular}{|c|c|c|c|c|}
\hline $\begin{array}{l}\text { Bergsma }{ }^{n} \\
1984\end{array}$ & $\begin{array}{l}\text { Pre-Exp. } \\
\text { (12 months) }\end{array}$ & Consultation & $\begin{array}{l}28 \mathrm{GPs} \\
\text { Oncologists }\end{array}$ & Oncological patients \\
\hline $\begin{array}{l}\text { Vierhour }{ }^{\circ} \\
1987\end{array}$ & $\begin{array}{l}\text { Pre-Exp. } \\
\text { (8 months) }\end{array}$ & $\begin{array}{l}\text { Joint } \\
\text { consultation }\end{array}$ & $\begin{array}{l}3 \text { GPs } \\
\text { Orthopedic surgeons, } \\
\text { Ear, nose and throat } \\
\text { specialist, Dermatologist }\end{array}$ & $\begin{array}{l}80 \\
\text { Chronic complex } \\
\text { problems (muscuio- } \\
\text { skeletal) complaints }\end{array}$ \\
\hline $\begin{array}{l}\text { Smit ws } \\
1987 \text { \& } 1990\end{array}$ & $\begin{array}{l}\text { Pre-Exp. } \\
\text { (12 months) }\end{array}$ & $\begin{array}{l}\text { Consultation } \\
\text { meeting }\end{array}$ & $\begin{array}{l}25 \text { GPs } \\
2 \text { Paediatricians, Ear, } \\
\text { nose and throar specialist }\end{array}$ & $\begin{array}{l}82 \\
\text { Pulmonary problems in } \\
\text { children }\end{array}$ \\
\hline $\begin{array}{l}\text { Pop } 72 \text {. } \\
1984,1987 \text { \& } 1989 .\end{array}$ & $\begin{array}{l}\text { Pre-Exp: } \\
\text { (7 years) }\end{array}$ & $\begin{array}{l}\text { Consultative } \\
\text { referral or by } \\
\text { telephone }\end{array}$ & $\begin{array}{l}80 \text { GPs } \\
\text { Medical Diagnostic } \\
\text { Centre }\end{array}$ & $\begin{array}{l}\text { Diversity of diagnostic } \\
\text { requests }\end{array}$ \\
\hline $\begin{array}{l}\text { Kaijvenhoven } 100 \\
1988.1990 \text { \& } 1991\end{array}$ & $\begin{array}{l}\text { Pre-Exp. } \\
\text { (two-studies) }\end{array}$ & $\begin{array}{l}\text { Consultation } \\
\text { among peers }\end{array}$ & $\begin{array}{l}\text { part 1. } 222 \text { GPs } \\
\text { part 2. } 49 \mathrm{GPs}\end{array}$ & 5 written cases per GP \\
\hline $\begin{array}{l}\text { Avenarius }{ }^{\circ} \\
1991\end{array}$ & $\begin{array}{l}\text { Pre-Exp. } \\
\text { (12 months) }\end{array}$ & $\begin{array}{l}\text { Consultation } \\
\text { by telephone }\end{array}$ & $\begin{array}{l}\text { GPs and Foundation } \\
\text { Suplementary Care } \\
\text { Provision }\end{array}$ & $\begin{array}{l}50 \\
\text { Patients with AIDS }\end{array}$ \\
\hline $\begin{array}{l}\text { Locht }{ }^{2} \\
1994\end{array}$ & $\begin{array}{l}\text { Pre-Exp: } \\
\text { (120 months) }\end{array}$ & $\begin{array}{l}\text { Stuctured } \\
\text { consultation by } \\
\text { telephone }\end{array}$ & $\begin{array}{l}85 \text { GPs. } \\
\text { Internist, PuImonary } \\
\text { specialist, Urologist, } \\
\text { Cardiologist ete. }\end{array}$ & $\begin{array}{l}1017 \\
\text { Patients with multiple } \\
\text { and complex health } \\
\text { problems }\end{array}$ \\
\hline $\begin{array}{l}\text { Phillipsen }{ }^{6} \\
1994\end{array}$ & $\begin{array}{l}\text { Pre-Exp. } \\
\text { (survey) }\end{array}$ & $\begin{array}{l}\text { Consuitarion } \\
\text { by tefephone }\end{array}$ & 667 GPs & $\begin{array}{l}\text { Euthanasia, physician- } \\
\text { assisted suicide }\end{array}$ \\
\hline $\begin{array}{l}\text { Onwuteaka }{ }^{* 4} \\
1999\end{array}$ & $\begin{array}{l}\text { Pre-Exp. } \\
\text { (survey) }\end{array}$ & $\begin{array}{l}\text { Consultation } \\
\text { by telephone }\end{array}$ & 405 GPs & $\begin{array}{l}\text { Euthanasia. physician- } \\
\text { assisted suicide }\end{array}$ \\
\hline $\begin{array}{l}\text { Suijlekom } \\
1995\end{array}$ & $\begin{array}{l}\text { Pre-Expt } \\
\text { (12 months) }\end{array}$ & $\begin{array}{l}\text { Consultative } \\
\text { referral }\end{array}$ & $\begin{array}{l}\text { GPs } \\
\text { Paediatricians }\end{array}$ & $\begin{array}{l}51 \\
\text { Health problems in } \\
\text { children }\end{array}$ \\
\hline
\end{tabular}


(1) positive: education, continuity of care. substitution towards primary care

(1) positive: substitution of care, continuity of care education. communication. cooperation

(1) positive: continuity of care, cooperation. education, substitution towards primary care
- consultation met the needs of GPs

- prevention unnecessary referrals to medical specialists

- knowing each other

- prevention unnecessary referrals to medical specialists

- improved efficiency of care

- joint consultations substitute for referral to medical specialist

Others

(1) positive: cooperation, communication with medical specialists, knowing each other

(1) positive: education, cooperation. respecting each other's competencies

(1) positive: cooperation, education, continuity of care, substitution towards primary care

(I) positive: education. continuity of care. better management policy and joint care (cooperation), GPs satisfied with process.

(1) positive: education, cooperation, decrease in the number of diagnosic tesis

(1) posirive: more attention for somatic problems, decrease of professional uñ certainty, long-term evaluation of their management process and patient outcome

(i) positive: education

(1) positive: continuity of care, management policy. GPs satisfied with process

(1) positive: in most cases agreemen! between consultant and consultee:

(1) positive: conșultation important and formal role in reviewing cases and decision making

(1) positive: substiturion towards primary care. GPs satisfied' with process

(2) parients (and parents) satisfied with process
- diagnostic information only

- more diagnostic actions / referrals by OPs

- no substitution effect

- appropriate referral or consultation request

- less referrals than expected

- patients were different when compared with usual care

- lack of specific knowledge GPs in oncologie

- beiter consensus about lasks, responsibilities and referral

- patiens were differen when compared with usual care

- GP more compliant with recommendations by individual feedhack - increase in number of consultations 1979-84; decrease in 1985-86

- 1. survey-research and 2. Written simulation case discussions

- single handed GPs make less use of constultations than GPs woiking with one or more pariners

- one-third of the GPs comsulteû colleagues frequently
- less referrals than expected

- survey-research

- most patients were alsci evaluated by the consultant

- survey-research

- consultation procedure must be standardized

- parients were differene when compared with usual care; parients had lang-term complaints and were frequent visiting theif GF prior the consultation

- most of the recommendations were not followed by GP 
Other reported effects of consultation are agreed policies and improved task specification. ${ }^{53-57}$ With respect to GPs, the consultation model provides a starting point for the translation of the philosophy of joint care into practice. ${ }^{30-33,41-43,49.52,53-55}$ Some authors suggest that consuitation will improve the behaviour of the patient with respect to somatic fixation and medical shopping. ${ }^{30-32,44,48,49,53}$ Some studies looked into longer term changes in GPs' performance and the effects on their management policy. ${ }^{31,32,41-43,51,56,57}$ Explanations given were that GPs, on the whole, have little influence on referrals, or, that the need for consultation may be reduced as a result of learning effects.

No clear differences in efficacy were found between several different modes of consultation, nor between different medical specialisms. However, it should be noted that there were considerable variations in the duration of the studies, patient populations, health problems, the number of consultants, and the outcome measurements used. Four studies that measured GP's satisfaction with the outcome and process of consultation concluded that the GPs were satisfied with both the process and outcome. . $^{40,54,55,62,65}$

\section{Effects on outcome of care}

The effects of consultation on patient outcome were less frequently studied. Four studies showed that the consultation model had improved the clinical status of patients. ${ }^{37-39,41-43,45}$ The most valid evidence was provided by Vierhout et al. ${ }^{41-43}$ Compared to the control group, the perceived health status of patients in the experimental group was significantly better.

The patients were satisfied with the process and outcome of care and with the process of consultation ( 5 studies). . $^{33 \cdot 35,40-43,65}$

\section{Prerequisites of and barriers to consultation}

Generally, in order to make optimal use of consultation, demands are made on both consultants and consultees. The basic conditions most often mentioned are: clearly defined responsibilities; motivation; a well-organised system of communication and reporting; mutual confidence, openness and concern..$^{30-32.41-43.53-57}$ The consultee must define the consultation request and provide the consultant with written information about the patient's problems. This information must provide insight into the patient' problems, and report treatment interventions undertaken so far. The consultant must have considerable experience of the particular category of patient, and it is recommended that the consultant has no financial interest in the case.

The introduction of referral to and consultation (or structured meetings) between two or more health workers is being impeded by a lack of time to consult, and by the present system of financing in which working-time spent in communication is not rewarded financially. ${ }^{30-32,41-43.56,57,65}$ 


\section{Comment}

Consultation models of interaction between GPs and medical specialists for patients for whom decisions about appropriate diagnostic testing or therapeutic management are difficult are thought to be helpful. This is illustrated by the studies of Pop ${ }^{66}$ and Winkens et al ${ }^{67}$ in which they demonstrated that $30-40 \%$ of new referrals by the GPs to the internists could have been prevented by a form of consultation. However, this review of the process of care and clinical outcome of the consultation models utilized in the Dutch primary health care system shows a lack of rigorous research. Our study included 27 studies of which only one study was a RCT. Definite conclusions about the effectiveness of the consultative procedures, both on the effects on the process and on the outcome of care, can not be determined. While the paradigm of clinical research is the randomized controlled trial, which is indispensable for methodological rigor, there are also several methodological difficulties executing such studies. Evaluating the efficacy of consultative procedures is difficult since they were applied in a variety of settings, medical specialists, expertise, patients, health problems, goals or reasons for consultation, and a broad range of outcome measurements ranging from patients' health status to attitudes of physicians and the impact on their performance (behaviour). Moreover, RCTs are expensive to perform and usually require volunteer health care professionals willing to evaluate their attitude, impact on their performance and management plan and their patients' health status, which may limit the external validity of the results. Despite these methodological problems, without controlled study designs, efficacy remains unclear. Nevertheless, the uncontrolled studies reviewed in this paper provide useful information that adds to our understanding of the need and impact of some types of consultative approaches on the process of care, patient outcome and satisfaction with the process of consultation.

Yet even the fairly loose methodological studies done to date suggest beneficial effects of the consultative approaches by improving cooperation within the existing structure, whereby there is easy access to specialist opinion without the loss of the responsibility for, and continuity of, care. Although the positive results, as examined by the uncontrolled studies, were questionable, the effects seen in the solitary controlled study were congruent. ${ }^{4 / 43}$

Further research must be carried out to study the optimal circumstances in which the maximum effect of consultants can be achieved. In addition, the timing of the consultation and the long-term effects should be considered.

In almost all studies there was an overwhelming agreement that every type of consultation model used fulfilled the GP's individual needs. The GPs considered the feedback they received in most of the cases to be adequate and helpful in determining their management plan, though not necessarily leading to changes in their management plan. The experience of GPs was that the consultation was of educational value. The results of the review also suggest that consultative approaches enhance communication 
between the GP and consultant and decrease the fragmentation of care. Both the GPs and the consultants emphasized the value of improved communication in maintaining or improving the quality of care. This may be the key ottcome for the succesful implementation of the consultative approaches used and can be considered as the key factor in enhancing the philosophy of joint care. Although the ultimate goal of consultation is to ensure optimal patient care, a direct relationship between better communication and improved patient outcome remains unproved.

Also, consultation may be regarded as a policy tool for the reduction of the costs of health care by shifting care towards less specialised provision. ${ }^{68-71}$ Evidence in respect of the impact of consultation as a substitute for referral is not proven. In most of the studies, consultation had led to a decrease in the number of referrals to medical specialists. However, the maintenance of these changes in referral pattern, or improvements in skills, performance, and attitude by GPs, must be examined after longer follow-up periods.

Another remarkable point is that the only RCT included ${ }^{41-43}$ showed that joint consultations will have a substitution effect from secondary towards primary care, while some other observational studies showed that patients referred for consultation differed from those receiving usual care (different patient populations).

For the succesful implementation of consultation models, barriers need to be removed. The literature indicates noticeable deficits in communication skills, lack of uniform guidelines for the process of consultation (procedures) to ensure optimal patient outcome and, above all, time ${ }^{68.71}$ Both GPs and consultants need to be aware of the prerequisites of optimal consultation, such as: the desire and opportunity to work together, and insight into each other's way of working. To optimise the benefit of (a one-time) consuitation, GPs shouid receive formal instruction in consultation skills during their training: breakdowns in the process of consultation may result in diminished patient care, patient frustration and confusion, and strained relations betweens physicians or other heatth care providers. Notwithstanding, consultation services are a promising way of improving communication between GPs and medical specialists. The further development of consultation approaches between GPs and health care providers has a great potential for the improvement of the continuity and quality of primary care.

The basic conditions are: clearly defined responsibilities; motivation; a wellorganised system of communication and reporting; mutual confidence, openness and concern. The consultee must clearly define the consultation request and provide the consultant with written information about the patient's problems. This information must provide insight into the patient's problems, and report treatment interventions undertaken so far. Kersten ${ }^{28}$ and some others ${ }^{31,32,41,43.66 .08 .71}$ has proved the importance of formulating a procedure proposal in the letter of referral. The purpose of the letter of referral is defined as: the GP's power to influence the nature, the extent, and the course of subsequent treatment. Unless GPs clearly emphasize that the referral is for consultation, specialists generally will not treat it as such. ${ }^{28.70}$ However, when the GP 
makes an explicit request for consultation it rarely results in treatment being taken over. ${ }^{28.70}$ The importance of an adequate letter of referral is being recognised by the profession since there is a National Guideline (NHG-Standaard) on the subject. ${ }^{n}$ Also, its importance is recognised in the 'basic task package' which states that the GP must retain responsibility for the referred patient. ${ }^{1,2.72}$ Further, it is important for the adequacy of a consultation referral that the consultant has no financial interest in a referral for treatment.

\section{Conclusion}

The results of this review of the effects on the process and outcome of care through the implementation of different types of consultative models of interaction with other health professionals suggest that communication between disciplines was improved, and that the educational needs of GPs were met. However, there is no convincing evidence that these consultation models lead to clinical benefit and cost savings. More rigorous studies are needed to evaluate the effectiveness of consultation in a variety of providers, settings, diseases, and patients.

\section{References}

1. Landelijke Huisartsen Vereniging. Het basistakenpakket van de huisarts. Utrechi: LHV Vademecum, 1987.

2. Geijer RMM, Burgers JS, Laan van der JR, Wiersma TJ, Rosmalen CFH, Thomas S [Eds]. NHGStandaarden voor de huisarts, deel 1. Maarssen: Elsevier/Bunge, 1999.

3. Raad voor Maatschappelijke. Ontwikkelingen (RMO) / Raad voor de Volksgezondheid en Zorg (RVZ). Achtergrondstudies bij het advies zorgarbeid in de toekomst. Den Haag/Zoetermeer: RMO/R.VZ, 1999.

4. Raad voor de Volksgezondheid en Zorg (RVZ). Naar een meer vraaggerichte zorg. Zoetermeer: RVZ, 1998 .

5. American Board of Internal Medicine. A statement on the generalist phyșician from the American Boards of family practice and internal medicine. JAMA 1994:271(4):315-316.

6. Joint Working Party of the Welsh Council of the Royal College of General Practitioners and the Welsh General Medical Services Committee. Parient care and the general practitioner. BMJ 1994: 309: 1144-1147.

7. Stichting Toekomstscenario's Gezondheidszorg (STG). Managed care and disease management. Zoetermeer: STG, 1997.

8. Ministerie van Welzijn, Volksgezondheid en Cultuur. Over de ontwikkelingen van gezondheidsbeleid: feiten, beschouwingen en beleidsvocrnemens (Nota-2000). Rijswijk, 1986.

9. Kwaliteit in beeld. Special Kwaliteitsconferentie en Leidschendamafspraken, 1995-2000. Zoetermeer: Gezamenlijke uitgave van de NRV en de Geneeskundige Hoofdinspectie, 5e jaargang, nr. 3, blz.3-6, 1995.

10. Grundmeijer HGLM, Weent van HCPM, Brouwer HJ. Wat is goed verwijzen en kan het beter? Een literatuuronderzoek. Huisarts Wet 1996;39:113-119.

11. Lisdonk van de FH, Schellevis FG. Interdoktervariatie en de kwaliteit van verwijzen. Een literatuuronderzoek. Huisarts wet 1994;37:573-578.

12. Winter F. De pijn de baas. Soest: RuitenbergBoek, 2000. 
13. Raad voor de Volksgezondheid en Zorg (RVZ). Redesign van de eerste lijn in transmuraal perspectief. Zoetermeer: RVZ, 1998.

14. Raad voor de Volksgezondheid en Zorg (RVZ). Transmurale zorg: redesign van het zorgproces. Zoetermeer: RVZ, 1998.

15. Wolff $\mathrm{N}$. Professional uncertainty and physician medical decision-making in a multiple treatment framework. Soc Sci Med 1989;28:99-107.

16. Velden van der LFJ, Hingstman L, Groenewegen PP. Verkenning van vraag- en aanbodontwikkelingen binnen de medische en paramedische zorg: knelpunten en oplossingen. In: Raad voor Maatschappelijke Ontwikkelingen (RMO) / Raad voor de Volksgezondheid en Zorg. (RVZ). Achtergrondstudies bij het advies zorgarbeid in de toekomst. Den Haag/Zoetermeer: RMO/RVZ, 1999.

17. Centraal Bureau voor de Statistiek. Statistisch jaarboek 1999, 's-Gravenhage: Staatsuitgeverij, 2000.

18. Fertig A, Roland M, King H, Moore T, Understanding variation in rates of referral among general practitioners: are inappropriate referrals important and would guidelines help reduce to reduce rates? BMJ 1993:307:1467-1470.

19. Roland M. General practitioners referral rates, interpretation is difficult. BMJ 1988:297:437-438.

20. Wilkin D. Metcalfe DH, Marinker $M$. The meaning of information on general practitioners referral rates to hospitals. Community Med 1989;11:65-70.

21. Joosten JA, Daams J, Knottnerus JA. Verwijzingen naar de internist: een vergelijkend retrospectief panelonderzoek naar de kwaliteit van verwijzingen van huisartsen die veel en huisartsen die gemiddeld naar de internist verwijzen. Med Contact 1990;45:83-85.

22. Coulter A, Noone A, Goldacre M. General practitioners' referrals to specialist outpatient clinics! Why general practitioners refer patients to specialist outpatient clinics. BMJ 1989;299:304-308.

23. Reynolds D. Chitnis JE, Roland MO. General practitioners referrals: do good doctors refer more patients to the hospital? BMJ 1991;302:1250-1252.

24. Knotnerus JA, Joosten J, Daams J. Comparing the quality of referrals of general practitioners with high and average referral rates: an independent panel review. Br J Gen Pract 1990;40:178-181.

25. Rowland MO, Porter R, Mathews JG et al. Improving care: a study oforthopaedic out-patient referrals. BMJ 1991;302:1124-1128.

26. Grace JF, Armstrong D. Referral to hospital: perceptions of patients, general practitioners and consultants about necessity and suitibility of referral. Fam Pract 1987;4:170-175.

27. NRV, Nationale Raad voor de Volkgezondheid. Nota indicatiestelling in de gezondheidszorg; nota. inzake de indicatiestelling in de gezondheidszorg en de maatschappelijke dienstverlening. Publikatic 4/90. Zoetermeer: NRV, 1990.

28. Kersten TJJMT. De invloed van de huisarts op de specialist. Een theoretische analyse getoetst aan de opvattingen van huisartsen. T Soc Gezondheidszorg 1992;70:171-179.

29. Sladden MJ, Gragam-Brown RAC. How many GP referrals to dermatology outpatients are really necessary? JR Soc Med 1989;89:347-348.

30. Grinten $\mathrm{R}$ van der. Communicatic huisarts-internist. Vier jaar ervaring met consultatie in het gezondheidscentrum Withuis. Medisch Contact 1981:36:777-781.

31. Pop P. Consultatie eerste-tweede lijn. Drie jaar Diagnostisch Centrum Maastricht. Medisch Contact 1982:34:1019-1023.

32. Pop P, Kerkhof PD. Diagnostisch Centrum Maastricht, Eindevaluatie van een experiment. Medisch Contact 1984;39:749-752.

33. Brouwer W. Het eenmalig geriatrisch consult. Huisarts Wet 1983;26:140-144 .

34. Braak E, Lange L de, Cleton-van de Dikkenberg E. Een geriatrisch consultatiepunt voor huisartsen. Medisch Contact 1989:44:717-719.

35. Braak E, Lange de L. Van geriatrisch consultatiepunt voor huisartsen naar vakgroep Geriatrie Gerontologie. Een Utrechts experiment. Medisch Contact 1993:29/30:908-910.

36. Fockert JA de. De geriatrische polikliniek van een algemeen ziekenhuis. Resultaten van een vernieuwde opzet. Medisch Contact 1985;40:294-296.

37. Wersch-van der Spek MCM. De verpleeghuisarts als medisch consulent in de eerstelijnsgezondheidszorg. Medisch Contact 1987:1987:1243-1244. 
38. Wersch-van der Spek MCM, Kocken PL. Ervaringen met de consultatiefunctie van het verpleeghuis in het verzorgingshuis. Medisch Contact 1990;45:385-87.

39. Willemse JMA, Fiolet FFBM. Geriatrie in de periferie. Medisch Contact 1989;44:715-717.

40. Collijn Th, Kerkstra A. Consultatie bij complexe geriatrische problematiek. Medisch Contact 1994:49:643-645.

41. Vierhout WPM. Het gezamenlijk consult van huisarts en specialist in de eerste lijn. Een nieuwe werkwijze bij klachten van het bewegingsapparaat [Dissertatic]. Maastricht: Rijksuniversiteit Limburg. 1994.

42. Vierhout WPM, Knottnerus JA, van Ooij A, Crebolder HFJM, Pop P, Wesselingh-Megens AMK, Beusmans GHMI. Effectiveness of joint consultation sessions of general practitioners and orthopaedic surgeons for locomotor-system disorders. Lancet 1995;346:990-994.

43. Ooij A van, Walenkamp GHIM, Gesink RGT, Arens HJ, Vierhout WPM, Knottnerus JA. Medisch Consultatie in de huisartspraktijk. 1. Een specialistische impressie. Medisch Contact 1992;47:118120.

44. Bensing JM, Kluver R, Schut H, Verhaak P. Consultatieproject Eindhoven, eindevaluatie, Utrecht: NHI, 1980.

45. Buis WJMN. Psychiatrische diagnsotiek en advies ten dienste van de huisarts. Amsterdam (Dissertatie): Uitgeverij Thesis, 1994

46. Verhaak PFM, Collijn D, Wijkel D, Feltz-Cornelis CM van der, Huijse F. Psychiatrisch consult in de huisartspraktijk. Medisch Contact 1994;49:1319-1321.

47. Collijn D, Wijkel D, Feltz-Cornelis CM van der, Verhaak P, Huijse FJ. Psychiatrische consulten bij somatiserende patiēnten in de huisartspraktijk. Een haalbaarheidstudie. Utrecht: Nivel/VU, 1994.

48. Hageman GCHA, Jansen HDM. Een voorbeeld van samenwerken in de verloskunde, Huisarts Wet $1984 ; 27: 456-457$.

49. Hall EV van, Gill K, Trimbos JB. Gynaecologische consulıaties in de huisarlspraktijk. Medisch Contact 1987; 42:105-106.

50. Boer den F, Hageman GCHA, Waal MWM, Peri H. Hel gezamenlijk consult in de eerste lijn. Een alternatief voor het verwijzen naar de tweede lijn? Medisch Contact 1996;51:221-223.

51. Grijn D van der, Wijkel D. Huisarts en Diagnostisch Centrum Oudenrijn. Utrecht: NHi/NZi, 1982.

52. Bergsma J. Huisarts en Oncologische consultatie. Huisarts Wet 1984;27:370-372.

53. Vierhout W. Gezamenlijk consult huisarts-specialist. Medisch Contact 1987;42:106-109.

54. Smit DJ de. Consultatie huisarts-specialist. Experiment bij kinderen met luchtwegproblemen. Medisch Contact 1987;42:849-852.

55. Smit DJ de. Ervaringen met consultaticbijeenkomsten. Medisch Contact 1990;47:1413-1415.

56. Pop P, Beusmans GHMI, Knottnerus JA. Een diagnostisch centrum voor Maastricht. Versterking van de eerste lijn en samenwerking huisarts-specialist. Medisch Contact 1987;42:845-848.

57. Pop P, Winkens RAG. A diagnostic centre for general practitioners: results of individual feedback on diagnostic actions. JR Coll Gen Pract 1989;39:507-509.

58. Kuyvenhoven MM, Pieters HM, Jacobs HM, Touw-Otten FWMM, Spreeuwenberg C. From no consultation to peer review. Scand J Prim Health Care 1988;6:5-12.

59. Kuyvenhoven MM, Pieters HM, Jacobs HM, Touw-Otten, Spreeuwenberg C. Do peei consiltations improve quality of care in general practice? Quality Assurance in Health Care 1990;2:171-179.

60. Kuyvenhoven MM, Pieters HM, Jacobs HM, Touw-Otten, Spreeuwenberg C. Gezondheidscentra springen er in gunstige zin uit. Medisch Contact 1991:46:51-54.

61. Avenarius $W$, Heijnen AM, Kloosterman HM, Wigersma L. De AIDS-consultatielijn voor huisartsen. Medisch Contact 1991;46:1212-1214.

62. Locht HPJ, Beusmans GHMI, Pop P. Het gestructureerde telefonisch consult. Werkelijkheid versus wenselijkheid. Medisch Contact 1994:49:608-610.

63. Philipsen BD, van der Wal G, van Eijk JThM. Consultatie bij euthanasie en hulp bij zelfdoding. Huisarts Wet 1994;37:478-481.

64. Onwuteaka-Philipsen BD, Kriegsman DMW, van der Wal G, Dillmann RJM, van Eijk JThM. General Practitioners'opinions on consultation of another physician in case of euthanasia. European Journal of General Practice 1999;5:137-143. 
65. Suijlekom-Smit LWA van, Crone-Kraaijeveld E. Het zieke kind, een zorg voor huisarts en kinderarts [Dissertatie]. Rotterdam: Erasmus Universiteit Rotterdam, 1994.

66. Pop P. De zorg ontkent? in ketens. Afscheidsrede Prof.dr. P.Pop. Universiteit Maastricht: 28 april 2000, Maastricht.

67. Winkens R, Pop P, Buyten-Maassen A, Grol R, Kester A, Beusmans G, Knottnerus J. Randomised trial of routing individual feedback to improve rarionality and reduce numbers of test requests. Lancet 1995:345:489-502.

68. Beek M, Eijk J van, Rutten G. Verschuivingen van eerste naar tweede lijn? Opvattingen van huisartsen en specialisten. Medisch Contact 1985;40:299-302:

69. Franks P, Clancy CM, Nutting PA. Gatekeeping revisited-protecting patients from overtreatment. N Engl J Med 1992;327(6):424-429.

70. McPhee SJ, Lo B, Saika Y, Meltzer R. How good is communication between primary care physicians and subspecialty consultants? Archives of Internal Medicine 1984;144:1265-1268.

71. Carne S. A problem halved? Journal of the Royal College of General Practitioners 1982;32:10-31.

72. Nederlands Huisartsen Genootschap. De verwijsbrief naar de Tweede Lijn - standaard $00 \mathrm{l}$. Huisarts Wet 1989:32:102-105. 


\section{PART II}

Preliminary Studies, Research Questions, and Design of the Study 


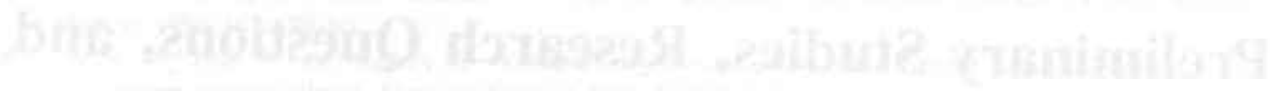

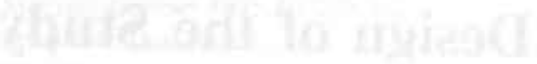




\title{
Experiences with Physiotherapist's Consultation Results of a Feasibility Study
}

\begin{abstract}
Ongoing developments in physiotherapy practice make it impossible for general practitioners (GPs) to remain adequately informed of the indications for physiotherapeutic intervention. To improve the quality of care, physiotherapists should be consulted if GPs are uncertain of the indications for physiotherapy. A pilot study was conducted as part of the main observational study on the effects and feasibility of physiotherapist's consultation in general practice. The overall objective of the study was to establish whether consultations by physiotherapists would influence the number of referrals made by GPs to medical specialists and physiotherapists in either a qualitative or quantitative way. The aim of the feasibility study was to assess the consultation procedure between 14 GPs and 8 physiotherapists. The data were collected using questionnaires and registration forms. On average, the GPs requested one consultation every 2 weeks (total referrals $=93$, range $=1-30$; mean referral rate $=12$ per 1000 patients). The GPs found both the consultation procedure and the standard consultation forms to be suitable for the purpose of consulting a physiotherapist. In $93 \%$ of cases, GPs felt the outcome of the consultation to be satisfactory. Eighty-nine percent of GPs followed the advice of the physiotherapist; in $58 \%$ of cases, this resulted in a different management of the patient than that intended prior to consultation. The present results suggest that the appropriateness of referral can be improved by written communication between a GP and physiotherapist.
\end{abstract}

\section{Introduction}

The policy of current Dutch primary health care is to provide for accessible and quality care that is both efficient and effective. ${ }^{1.2}$ Cost containment, however, is often the aim of policy initiatives and directives. 
This makes it necessary to make choices in the provision of care by physiotherapists and to develop policies that will improve the efficiency of that care.

In the Dutch health care system, general practitioners (GPs)/primary care physicians have a key role to play as gatekeepers to other health care services. They are usually the first health workers to be contacted for health-related problems. Within GP practices, patients most often present with locomotor and respiratory complaints. ${ }^{3.4}$ Other health workers, including physiotherapists and medical specialists, are only seen by patients after referral by their GP. As $80 \%$ of patients seen by a physiotherapist are referred by their GP, the physiotherapist-GP relationship is an important one.

Problems relating to communication, indications for physiotherapy and GPs' knowledge of physiotherapeutic possibilities have been identified. ${ }^{5-8}$ One main aim of government primary health care policy is to improve communication between physiotherapists and GPs. ${ }^{5}$ Research has shown great variability in the kinds and numbers of patients referred by GPs to physiotherapists and the knowledge GPs have of physiotherapy practice. ${ }^{4.9}$ Many GPs also doubt the efficacy of physiotherapeutic interventions. One possible solution is for GPs, when in doubt about the indication for physiotherapy, to consult a physiotherapist prior to possible referral for treatment. At present, GPs decide on the basis of a medical diagnosis whether physiotherapy is indicated or not. Physiotherapists' unique knowledge and skills in the area of human locomotion allows them to offer a complementary, or even refined, diagnosis. This is important for the well-being of the patient, because the GP's medical data and diagnosis may not be sufficient to direct a physiotherapeutic intervention. ${ }^{10-16}$

Physiotherapy is often directed at the (perceived) functional status of a patient related to the disorder or disease rather than at the disorder or disease itself. As in rehabilitative medicine, the International Classification of Impairments, Disabilities, and Handicaps (ICIDH) is increasingly being used in the Netherlands to describe the health status of patients at three distinct functional levels: impairment (organ), disability (person), and handicap (society). ${ }^{17}$ In the physiotherapy and allied health professions, the results of physical examination and treatment goals are increasingly being formulated within the framework of the ICIDH. ${ }^{14.18-23}$

The Dutch Ministry of Health, Welfare and Sports has requested the National Institute of Allied Health Professions (NPi) and the Netherlands Institute of Primary Health Care (Nivel) to assess the outcome of GPs consulting physiotherapists. The Physiotherapy Act $(1977)^{23}$ only mentions referrals by GPs to physiotherapists for treatment. By enabling GPs to consult physiotherapists, a new dimension to the relationship between GPs and physiotherapists will be introduced. Consultation of a physiotherapist by a GP is defined as: "a written request by a GP to a physiotherapist to examine and evaluate a patient in order to obtain information regarding a diagnosis and prognosis which will facilitate the treatment plan of the GP, specifically when it concerns the possibilities for physiotherapeutic interventions."

The overall objective of the project was to establish whether consultations by physiotherapists would influence the number of referrals made by GPs to medical 
specialists and physiotherapists in either a qualitative or quantitative way. To our knowledge, no comparable research has been conducted on the effects of GPs consulting physiotherapists and the practicalities of the consultation procedure. ${ }^{25}$ We therefore planned two related studies, the first of which was to evaluate the feasibility of the consultation process and the practicality of the standard consultation forms. The second main study evaluated the effects of such consultations on the quality of referral and the efficiency of physiotherapeutic care.

This paper presents the results of the feasibility study, which are representative of the scope and design of the main field study. The key questions we wished the feasibility study to answer were grouped as follows:

1. Is the new consultation procedure feasible and how practical are the standard consultation forms?

2. How often are consultations requested? What sort of information is requested and what advice do the physiotherapists give? Are GPs really interested in consulting physiotherapists in the future?

3. How do GPs use the advice of physiotherapists and does it contribute to the decisionmaking process?

4. How can patients referred by GPs to physiotherapists be characterized? For example, in terms of complaint, localization of complaint, age, etc.?

5. What is the relationship between the medical diagnosis or referral data and the diagnosis established by the physiotherapist?

\section{Methods}

\section{Design and research population}

An exploratory, descriptive research design was employed. The study, which was conducted in a rural area, was of a pre-experimental nature (i.e., no control group was employed) and lasted 13 weeks. A questionnaire was developed to identify background characteristics of the participating GPs and physiotherapists. The 14 GPs (13 males, 1 female) were between $30-50$ years of age (mean $=40$ years), and had 1-23 years' (mean $=11$ years) experience. The mean number of patients on their registers was 2400 (range $=800-3500)$. The eight physiotherapists ( 7 males, 1 female) between 25-44 years of age (mean $=38$ years) had $6-20$ years' (mean $=12.5$ years) experience. To guarantee continuity of consultations, two physiotherapists were selected from each of the four participating private practices. An important prerequisite for participation by the physiotherapists was a willingness to cooperate, because non-cooperation would have defeated the object of the study. A request by a GP for a consultation could be for information regarding the indications for physiotherapy, diagnostic information, or both. 


\section{Procedure and standard consultation forms}

The procedure to request a consultation with a physiotherapist was as follows. The GP. having decided to consult a physiotherapist, completed a consultation request form. At that time, the GP was asked to put in writing the reason for his or her request, and what course of action he or she would have taken had the physiotherapist not been consulted. The patient then took the consultation request form to the physiotherapist, who conducted an examination after taking a patient history. The physiotherapist also analyzed the patient's functional health status in terms of impairment (including localization of involved tissues), disability and handicap using the ICIDH. ${ }^{17}$ The physiotherapist recorded his or her findings on two standard forms: one was used for the patient's personal and sociodemographic characteristics and the other for a description of the patient's functional health status. The physiotherapist then advised the GP, using a standard report form, of the indications for physiotherapy, treatment goals and management, and prognosis when applicable. The GP assessed the standard report form and indicated his or her preferred management of the patient on a 'consultation-evaluation' form.

The standard form used to request a consultation was developed according to the guidelines set out in a protocol of the Netherlands Association for General Practitioners. ${ }^{26}$ The International Classification of Primary Care (ICPC) was used to record the medical diagnosis/referral data. ${ }^{27}$ The various types of complaints were evaluated by means of open-ended questions. The data were coded according to the main ICPC categories. The functional status of the patients, which was part of the physiotherapist diagnosis, was described using the ICIDH. ${ }^{17,21}$ The reliability of the assessment forms based on the ICIDH has been shown to be satisfactory for a number of different health professions. ${ }^{18,19.23}$ The physiotherapists were asked to indicate which of the impairments or disabilities recorded would have formed the basis of their treatment plan.

Data relevant to the feasibility and usefulness of the procedure were obtained from the standard forms and the questionnaires completed by the participants at the onset and conclusion of the study. The questionnaires completed at the onset of the feasibility study were concerned with the personal characteristics of the participating GPs and physiotherapists, the organization of their respective practices, cooperation between disciplines, knowledge of each other's expertise, referral data and postgraduate qualifications. The questionnaires completed at the conclusion of the study were concerned with the appropriateness and practicality of the forms, possible changes to the relationship between GPs and physiotherapists, and the willingness of both groups to adopt the consultation procedure in the future.

\section{Data analysis}

Because of the nature of the feasibility study, the results are presented in the following descriptive format. 


\section{Results}

\section{Procedure and standard forms}

Thirteen of the 14 GPs and 6 of the 8 physiotherapists believed the consultation procedure could easily be incorporated in their daily routines. The GPs were asked how they had informed their patients of the physiotherapist's report: five GPs made an appointment with their patients at the time of referral, five asked their patients to contact them, and two contacted their patients directly. Two GPs did not indicate a preferred method.

The GPs were generally satisfied with the outcome of consultation and the time within which they received the physiotherapist's report. Evaluation of the consultation request form revealed that 11 GPs thought the form satisfactory for allowing the physiotherapist insight into the patient's condition. The average amount of time taken to complete the form was three minutes (range $=1-5 \mathrm{~min}$.). The physiotherapists thought the form provided sufficient information regarding the nature and course of a patient's complaint and possible psychosocial information to allow them to agree to a consultation request. Despite its relative unfamiliarity, seven of the eight physiotherapists were happy to describe the functional status of the patients using ICIDH terminology. On average, the physiotherapists required 40 minutes (range $=30-50 \mathrm{~min}$.) for history-taking and a physical examination. The time taken to write the report ranged from 10 to 30 minutes.

\section{Frequency of use of consultation}

During the 13-week study, 93 patients were referred for the physiotherapist's consultation. The number of consultations requested varied from 1 to 30 (median =5) for each of the GPs. This averages to one request per GP for physiotherapist's consultation every 2 weeks. This can be expressed as a mean of 12 referrals per GP for physiotherapist's consultation for every 1000 patients each year. The GP referral rate for physiotherapeutic treatment (without prior physiotherapist's consultation) in The Netherlands has been estimated to be 110 referrals per GP for every 1000 patients each year ${ }^{28}$

\section{Consultation and advice}

Of the 93 patients referred for the physiotherapist's consultation, $12(13 \%)$ were referred for further diagnostic information. For a further $47(51 \%)$, the GPs wished to know whether physiotherapy was indicated or not. In the remaining 34 cases (36\%), the GPs requested both types of information.

The physiotherapists advised physiotherapy in 55 cases (59\% of the total patients referred for physiotherapist's consultation), including advice/information $(n=7)$. In 7 cases $(8 \%)$, there was no indication for physiotherapy. In 10 cases (11\%), the physiotherapists thought a consultation by a medical specialist would be the most appropriate course of action. In 15 cases $(16 \%)$, the GPs were advised to consult or refer to another allied health care professional, in 4 cases $(6 \%)$, the physiotherapists requested further information from the referring GP before offering advice. 
Table 1. Treatment policy of GPs following consultation

\begin{tabular}{|c|c|c|c|}
\hline & $\begin{array}{l}\text { Intended policy } \\
\text { prior } \\
\text { to consultation }\end{array}$ & $\begin{array}{l}\text { Policy following } \\
\text { consultation }\end{array}$ & $\begin{array}{l}\text { Intended } \\
\text { policy } \\
\text { not changed }\end{array}$ \\
\hline Continue own treatment & 6 & 4 & 4 \\
\hline \multicolumn{4}{|l|}{ Consultation by telephone } \\
\hline medical specialist & 2 & - & - \\
\hline physiotherapist (informal)" & 5 & - & - \\
\hline \multicolumn{4}{|l|}{ Referral } \\
\hline medical specialist & 28 & 14 & 6 \\
\hline physiotherapist " & 39 & 55 & 27. \\
\hline other ${ }^{b}$ & 1 & 13 & 1 \\
\hline Joint examination & 2 & - & - \\
\hline Doubt/uncertainty ${ }^{c}$ & 9 & - & . \\
\hline Adjustment of treatment policy & NA & 5 & - \\
\hline Total & 92 & $91^{d}$ & 38 \\
\hline
\end{tabular}

Including one-time advicelinformation by physiotherapist

Referral to, for example, chiropodist, remedial exercise therapist GP did not specify treatment policy

The treatment policy following consultation of one patient is not known

NA Not applicable

In the case of 78 patients $(86 \%)$, the GPs followed the advice of the physiotherapists. Eleven GPs indicated that they would like the possibility of consulting a physiotherapist; one was not convinced of the need for consultation; and the other two did not express an. opinion. All eight physiotherapists expressed the view that they would like GPs to consult. them on a regular basis. Six physiotherapists indicaied a preference for joint consultations, with the GP and physiotherapist seeing the patient together.

\section{Quality of consultation and patient management}

Ninety-three percent of the GPs were of the opinion that the physiotherapists' reports had answered their questions satisfactorily. Twelve GPs indicated that the possibility of consulting a physiotherapist was a useful additional option in their choices of treatment. After receiving the physiotherapist's report, the GPs adopted a different treatment plan compared with that intended in 54 of the 93 referrals $(59 \%)$ (see Table 1).

For example, before the consultation process, the GPs had intended to refer 28 patients to medical specialists; after consultation, however, only 14 patients were referred. The GPs' intended treatment plan was unchanged in six patients. Of the 39 patients originally intended to be referred to a physiotherapist, 27 were referred following consultation. 


\section{Patient characteristics}

The medical diagnosis/referral data were classified using the ICPC ${ }^{27}$ Eighty-nine percent of the patients $(\mathrm{n}=82)$ presented with disorders of the locomotor system, $8 \%(\mathrm{n}=7)$ with neurological disorders, and $3 \%(n=3)$ with general unspecified complaints or vascular disorders. The GPs requested a consultation for just over $50 \%$ of the patients presenting with chronic complaints: duration of complaint more than 4 months, 19 patients; duration of complaint more than 12 months, 28 patients.

There was no obvious relationship between the age of the patient and the GP's request for a consultation; however, the GPs requested a consultation for twice as many women as men. Most patients had recurring conditions, with no history of previous trauma or accident.

The main reason for contacting their GP was pain ( $95 \%)$. These patients were characterized as having previous medical diagnostic procedures (e.g., X-rays) and as having received medical treatment (e.g., drugs) for the same complaint.

\section{Similarity between the two diagnoses}

Table 2 shows the relationship between the medical diagnosis of the GP and that of the physiotherapist at the level of impairment, disability and handicap. ${ }^{17}$ The table reveals a discrepancy between the medical diagnosis and the number of impairments, disabilities and handicaps for each diagnostic group.

By listing the impairments, disabilities and handicaps, localization of the condition and organs/tissue affected, it is possible to gain insight into the ways in which a particular disorder or disease affects individual patients or patient groups. Such a diagnosis can serve as the starting point for the formulation of a treatment plan based on an analysis of the relevant data. Table 2 shows the impairments and disabilities amenable to physiotherapeutic intervention.

It would appear that physiotherapists most often decide to treat patients at the level of impairment, occasionally at the level of disability, but never at the level of handicap.

\section{Comment}

Improvements in the efficiency of care are receiving more attention from health policy makers. Physiotherapy can be used more efficiently if GPs employ physiotherapists' expertise at an earlier stage. ${ }^{24.29}$ Ritchey et al conclude: "greater professional autonomy is likely to be acquired by physiotherapists making physicians aware of the extent of therapists' capabilities. " A number of studies have shown a deficit in GPs' knowledge ${ }^{28}$ and resident physicians' knowledge ${ }^{8}$ of physiotherapy. There is evidence to suggest that knowledgeable physicians refer more patients, and tend to be prescriptive, suggesting which treatment to apply. ${ }^{9}$ This may explain why a GP's knowledge about physiotherapy, close cooperation between GPs and physiotherapists, and the number of referrals, appear 
to be linked. The introduction of a new aspect of cooperation - referral for physiotherapist's consultation - could be instrumental in enhancing the efficiency of care, ${ }^{4.25 .28 .29}$ particularly if the GP is uncertain as to whether physiotherapy will be beneficial. Consulting with physiotherapists may also be educational for GPs, and improve their knowledge of the indications for physiotherapy, the skills of the physiotherapist, and the therapeutic potential of physiotherapy. Therefore, the quality and appropriateness of referrals may improve. ${ }^{8,22,25,30}$

Research has shown a wide variation in the treatment policies of GPs. ${ }^{4.6 .28 .31}$ This feasibility study has shown that there is considerable variation among GPs in the way they make use of physiotherapist's consultations. The rate of referrals for consultation in this study was low compared with the documented rate of referrals for treatment (12 vs 110 referrals per GP for every 1000 patients per year). At the conclusion of the study, the participating GPs were very positive about consulting physiotherapists in the future if they were in doubt as to the indications for physiotherapy. Both the GPs and physiotherapists found the consultation procedure and reporting forms to be suitable for the purpose of consulting a physiotherapist. The standard consultation form and reporting form are both considered valid reporting instruments.

In general, the GPs were satisfied with the way in which the physiotherapists answered their queries, and how relevant that information was for directing treatment. In 54 of 93 referrals for consultation ( $59 \%$ ), the GPs changed their initial treatment plan based on the information provided by the physiotherapist. When the data for referrals for consultation are compared with the national figures for referrals for treatment, ${ }^{28}$ some differences can be noted. For example, twice as many women as men were referred for consultations $(67 \%$ vs $33 \%)$, whereas almost equal numbers of women and men are referred for treatment ( $52 \%$ vs $48 \%$ ). In general, the patients referred for consultation tended to come from the younger age groups, and tended to have recurring and more chronic complaints. The main field study may show similar trends.

Although a GP's medical diagnosis determines to a large extent the physiotherapist's approach to assessment and treatment, it is now evident that medical information alone (i.e., diagnosis and referral data) is sometimes an inadequate starting point for efficient physiotherapeutic intervention. ${ }^{3,11,20,28}$ In rehabilitative medicine and the allied health professions, the concepts and terminology of the International Classification of Impairments, Disabilities and Handicaps (ICIDH) ${ }^{17}$ are increasingly being adopted because of the excellent conceptual framework they offer for the assessment of functional health status. Recently, Heerkens et $\mathrm{al}^{20}$ defined a diagnosis by a physiotherapist as: "The professional opinion of a therapist about the health status of a patient taking into consideration the underlying pathological process, based on referral data, data from history, data from physical examination and additional medical and psychosocial data." On the basis of the physiotherapist diagnosis, it will be possible to justify physiotherapeutic intervention, to formulate treatment goals, and to indicate which impairments, disabilities and handicaps can be addressed. 
Table 2. Relation between medical diagnosis (referral data ") and the functional status in gterms of impairments, disabilities and handicaps of the patient as part of the physiotherapist's diagnosis"

\begin{tabular}{|c|c|c|c|c|c|c|}
\hline \multirow[t]{3}{*}{ Functional status } & \multicolumn{6}{|c|}{ GP referral diagnosis } \\
\hline & \multicolumn{2}{|c|}{$\begin{array}{l}\text { Back complaints } \\
(\mathrm{n}=13)\end{array}$} & \multicolumn{2}{|c|}{$\begin{array}{l}\text { Neck complaints } \\
(\mathrm{n}=11)\end{array}$} & \multicolumn{2}{|c|}{$\begin{array}{l}\text { Shoulder complaints } \\
(\mathrm{n}=9)\end{array}$} \\
\hline & $\mathrm{n}^{4}$ & goals" & $\mathrm{n}^{4}$ & goalse & $n^{4}$ & goals: \\
\hline \multicolumn{7}{|l|}{ Impairments $(n=10)^{\circ}$} \\
\hline Pain & 13 & 7 & 9 & 6 & 9 & 6 \\
\hline Decreased range of motion & 9 & 6 & 10 & 6 & 5 & 3 \\
\hline Shortened muscle & 6 & 4 & 6 & 2 & 4 & 3 \\
\hline Hypertone muscle & 3 & 2 & 4 & 2 & 3 & 2 \\
\hline Decreased muscle strength & 3 & 1 & 3 & - & 5 & 2 \\
\hline Change in posture (body) & 5 & 4 & 5 & 2 & 4 & 1 \\
\hline Change in position (joint) & 6 & 5 & 6 & 2 & 3 & 2 \\
\hline Decreased active stability & 5 & 3 & 2 & 2 & 2 & 2 \\
\hline Impaired coordination & 2 & 1 & 4 & 2 & 3 & 1 \\
\hline Pliability of skin & - & - & 3 & 2 & 1 & 1 \\
\hline \multicolumn{7}{|l|}{ Disabilities $(n=9)^{\prime}$} \\
\hline Walking & 7 & 2 & - & - & - & $=$ \\
\hline Kneeling & 4 & - & 2 & - & - & - \\
\hline Changing position when lying down & 10 & - & 4 & - & 5 & - \\
\hline Changing position when sitting & 10 & 4 & 3 & 1 & - & - \\
\hline Maintaining a specific posture & 7 & - & 5 & 1 & $\cdot$ & $=$ \\
\hline Lifting/carrying & 9 & 3 & 5 & - & 7 & - \\
\hline Picking up/grasping & 10 & 1 & 3 & - & 6 & 2 \\
\hline Reaching & 8 & - & 4 & - & 7 & 2 \\
\hline Domestic activities & 13 & 1 & 7 & $=$ & 6 & - \\
\hline \multicolumn{7}{|l|}{ Handicaps $(n=4)^{r}$} \\
\hline Physical independence & - & $\cdot$ & 1 & - & - & $=$ \\
\hline Mobility & 6 & - & 1 & - & 2 & . \\
\hline Occupation & 10 & - & 5 & - & 5 & - \\
\hline Social integration & 4 & $\cdot$ & 2 & - & 1 & - \\
\hline
\end{tabular}

The referral data have been classified using the $I C P C^{27}$

An inventory of the functional status in terms of impairments, disabilities, and handicaps $s^{17}$

A selection of the mosi frequen impairments $(n=10)$, disabilities $(n=9$,$) and handicaps (n=4)$

- Number of recorded impairments, disabilities, and handicaps per ICPC code

- Number of recorded treatment goals at the tevel of impairments, disabilities, and handicaps

Table 2 shows how a medical diagnosis based on the International Classification of Primary Care $(\mathrm{ICPC})^{27}$ can be linked to the functional status of a patient in terms of impairments, disabilities, and handicaps. Patients with the same medical diagnosis (e.g., back, neck, or shoulder pain) may present with different impairments, disabilities, and handicaps. However, based on the physiotherapist diagnosis, a treatment plan can be formulated. Although physiotherapists are primarily concerned with the prevention and 
treatment of physical disabilities, ${ }^{16.28,33}$ this preliminary study has shown that they often decide to treat patients at the level of impairment.

Because the terminology used by the ICIDH is not always equivocal, and many impairments and disabilities relevant to physiotherapy are missing altogether, the main field study will make use of a proposed adapted ICIDH for the allied health professions. ${ }^{21}$

It became apparent that physiotherapists will need to be reimbursed for the time they spend examining patients and compiling their written consultation reports to GPs. In their consultations with patients, physiotherapists will need to assess the patient's functional status and any indications for physiotherapy, suggest a treatment plan, and possibly a offer prognosis of the outcome of physiotherapeutic intervention. In their written report to the GP, they will also have to take account of any ethical considerations together with the prevailing regulatory framework. The final responsibility for a patient's treatment, however, lies with the GP.

How important are the results of this study? At conferences in The Netherlands in 1989 and 1990, policy was formulated concerning the future quality of health care. ${ }^{34}$ In a review article, Sluijs and Bakker ${ }^{35}$ suggest that a start has been made with the development of quality assurance policies within physiotherapy. According to Sluijs and Bakker, ${ }^{35}$ the physiotherapist's consultation affects different components of quality assurance, namely efficiency and working methodology. We suggest other ways of ensuring quality physiotherapeutic care, including a uniform registration system, the use of classifications, the development of cooperation between GPs and physiotherapists, and greater communication with GPs. There are important practical implications for all concerned. In particular, GPs will be better informed of physiotherapeutic possibilities and will thus provide a greater quality of care. The consultation process between GPs and physiotherapists provides insight into the physiotherapeutic diagnostic and decision-making processes, which in turn enhances professional practice. ${ }^{4.7 .25}$

\section{Conclusion}

The consultation process suggested here will have an effect on proposed cost containment initiatives. The impact that such consultations will have on utilization of health care services will be explored in the main study. Ways to limit this impact need to be sought, and may include a more efficient referral system, and the prevention of unnecessary referrals. The nature of this feasibility study does not allow generalization of the results, due to the optimal conditions in which it was performed and the small numbers of GPs. and physiotherapists studied, between whom there was already good communication and cooperation. However, the aim of the feasibility study was simply to test the consultative process, the questionnaires employed, and the standard consultation forms developed. ${ }^{36}$ The process of written consultation was apparently justified by this study. 


\section{References}

1. Werken aan zorgvernieuwing:actieprogramma van het beleid voor de zorgsector in de jaren negentig: bijlage: notitie inzake stelselwijzigingen zorgsector. Tweede Kamer, vergaderjaar 1989-1990, 2 I 545, no's 1.2.

2. Kwaliteit van zorg 1990-1991. Verhandelingen van de Tweede kamer, vergaderjaar 1990-1991, 22 113, no's 1-2.

3. Dekker J, Baar ME, Curfs EChr, Kerssens JJ. Diagnosis and treatment in physical therapy: an empirical investigation of their relationship. Physical Therapy, 1993;73:568-577

4. Kerssens JJ, Groenewegen PP. Referrals to physical therapy: The relation between the number of referrals, the indication for referral and the inclination to refer. Social Science \& Medicine, 1990;30:797. 804.

5. Ministerie van WVC. Notitie Ontwikkeling Fysiotherapeutische Hulpverlening. Rijswijk, 1989

6. Anderson J, Campbell SK. Correlates of physician utilization of physical therapy. International Journal of Technology Assessment in Health Care. 1992;8(1):10-19.

7. Ritchey FJ, Pinkston D, Goldbaum JE, Heerten ME. Perceptual correlates of physician referral to physical therapist: Implications for role expansion. Social Science \& Medicine. 1989;28:69-80.

8. Stanton PE, Fox FK. Francois KM, Hoover DH, Spilecki GM. Assessment of resident physicians' knowledge of physical therapy. Physical Therapy. 1985;65:27-30.

9. Uili RM, Shepard K, Savinar E. Physician knowledge and utilization of physical therapy procedures. Physical Therapy. 1984:64:1623-1530.

10. Bowler Hulme J, Wackernagel B, Lewis JW. Communication between physicians and physical therapists. Physical Therapy. 1988:68:26-31.

11. Delitto A, Guccione AA, Jette A, et al. Diagnosis in Physical Therapy; a roundtable discussion. Magazine of Physical Therapy. 1989;58(6):58-65.

12. Magistro CM. Clinical decision making in physical therapy. A Practitioner's perspective. Physical Therapy. 1989;69:525-534.

13. May B, Dennis JK. Expert decision making in physical therapy. A survey of practitioners. Physical Therapy. 1991;71:190-202.

14. Mischner-Ravensberg van CD, Paauw HJM, Gestel JLM van. De fysiotherapeutische werkdiagnose in relatie tot de medische diagnose. Ned Tijdschr Fysiotherapie. 1988;98:104-107.

15. Rose S. Physical therapy diagnosis: role and function. Physical Therapy. 1987;67:535-537.

16. Sahrmann SA. Diagnosis and classification by physical therapist: a special communication. Physical Therapy. 1988;68:1703-1706.

17. WHO. The International Classification of Impairments, Disabilities, and Handicaps: a manual of classification relating to the consequences of disease. Geneva, World Health Organization, 1980.

18. Gisbergen van MJWM, Dekker J. Reliability of the diagnosis of impairments and disabilities by exercise therapists. J Rehab Sciences. 1992;5:67-73.

19. Gisbergen van MJWM, Dekker J, Zuijderduin W. Reliability of the diagnosis of impairments in survey research in the field of chiropody. Disabil Rehab. 1993;15:76-82.

20. Heerkens YF, Brandsma JW, Bernards ATM, Hendriks HJM, Lakerveld-Heyl K, Ravensberg CD, Wams HWA, Oostendorp RAB, Helders PJM. Zin en onzin van het gebruik van de ICIDH. Fysiopraxis. $1993 ; 18: 18-21$.

21. Heerkens YF, Brandsma JW, Ravensberg CD. Proposal for adaptation of the International Classification of Impairments, Disabilities, and Handicaps from the perspective of five Dutch health professions. Zoetermeer, Dutch Classification and Terminology Committee for Health (WCC), National Council for Public Health (NRV), 1993.

22. Hendriks HJM, Brandsma JW, Wagner C, Dekker J, Oostendorp RAB. Eerste ervaringen met het consultatief fysiotherapeutisch onderzoek. Ned Tijdschr Fysiotherapie. 1993;103:190-200.

23. Triet EF van, Dekker J, Kerssens JJ, Curfs EChr. Reliabiliry of the assessment of impairments and disabilities in survey research in the field of physical therapy. Int Disabil Stud. 1990; 12(2): 61-65.

24. Fysiotherapeutenbesluit. In: Staatsblad van het Koninkrijk der Nederlanden, 1977 no. 432: Besluit van 1 juli 1977 tot vaststelling van nieuwe regelen inzake het beroep van fysiotherapeut. 


\section{CHAPTER 4}

25. Hendriks HJM, Wagner C, Brandsma JW, Dekker J, Wams HWA, Oostendorp RAB. Consultatief Fysiotherapeutisch Onderzoek (CFO) in de eerste lijn. Introduktie van het CFO-project en informatie uit de literatuur. Ned Tijdschr Fysiotherapie. 1992;102:176-183.

26. NHG. De verwijsbrief naar de Tweede Lijn - standaard 001. Nederlands Huisartsen Genootschap, Huisarts Wet. 1989;32:102-105.

27. Lamberts H, Wood M. International Classification of Primary Care. Oxford University Press, Oxford, 1987.

28. Kerssens JJ, Curfs EChr. Extramurale fysiotherapie. Utrecht, PhD dissertation. Netherlands Institute for primary health care, 1993.

29. Bertels M, Brummeler L ten, Dijkum C van, Giebels R, Mannen J van der. Tijd voor kwaliteit: evaluatieonderzoek fysiotherapie in gezondheidscentra in Amsterdam. Amsterdam, Stichting Interuniversitair Instituut voor Sociaal Wetenschappelijk Onderzoek, 1985.

30. Bahrami J, Hamid Husain M, Clifton S, Pringle M, Hill FE, Richards DWL. Access to physical therapy services. Br Med J. 1983:287:25-28.

31. Hendriks HJM, Wagner C, Brandsma JW. Consultatie van de fysiotherapeut. Een middel voor betere samenwerking tussen huisartsen en fysiotherapeuten. In: Jaarboek Fysiotherapie 1993 (pp. 11-32), Bohn van Loghum, Houten, 1993.

32. Campbell SK, Anderson JC, Gardner HG. Use of survey research methods to study clinical decision making: referral to physical therapy of children with cerebral palsy. Physical Therapy. 1992; 69(7):610615.

33. Saunders C, Maxwell M. The case for counseling in physiotherapy. Physiotherapy. 1988;74:11:592-596.

34. Leidschendam Conferenties 1989/1990. Afspraken over kwaiiteitsbeleid. Vervolgconferentie over kwaliteit van zorg op 14 en 15 juni 1990 te Leidschendam. Zoetermeer: NRV, 1991.

35. Sluijs EM, Bakker D. De ontwikkeling van kwaliteitssystemen in de fysiotherapie. Ned Tijdschr Fysiotherapie. 1993;103:13-18.

36. Hendriks HJM, Brandsma JW, Wagner C, Dekker J. Het consultatief fysiotherapeutisch onderzoek in de eerste lijn. Eindverslag van fase 1. Amersfoort: SWSF, 1992. 


\section{Intraobserver and Interobserver Reliability of Assessments of Impairments and Disabilities}

\section{Abstract}

Background and Purpose. The concepts of the International Classification of Impairments, Disabilities, and Handicaps provide a framework for the assessment of functional status. The purpose of this study was to evaluate the intraobserver and interobserver reliability of assessments of impairments and disabilities. Subjects and Methods. One physiotherapist's assessments were examined for intraobserver reliability and judgments of two pairs of physiotherapists were used to examine interobserver reliability. Reliability was assessed by percentage of agreement and Cohen's kappa. Results. Of the 42 impairments and disabilities assessed by the physiotherapist in the intraobserver reliability segment of the study, kappa values could be calculated for 33 items. For 31 items (94\%), kappa values ranged from .40 to .91 , and 2 items (6\%) had kappa values of less than .40 . To determine interobserver reliability, 37 items were assessed in one practice. Kappa values could be calculated for 34 items, with 30 items (88\%) having kappa values ranging from .41 to .80 , and 4 items (12\%) showing poor agreement. In the second practice, 47 items were assessed for interobserver reliability. Kappa values could be calculated for 40 items, with 11 items $(27.5 \%)$ having kappa values ranging from .41 to .84 . Poor agreement was shown for the remaining 29 items $(72.5 \%)$. Ten of these items had negative kappa values, indicating that agreement was lower than could be expected on the basis of chance. Conclusion and Discussion. Assessment of impairments and disabilities are potentially reliable. The differences between practices of the interobserver reliability segment of the study can be explained by the fact that one of the physiotherapists did not receive training in the use of the assessment form. More general conclusions will require further study with more subjects and therapists. 


\section{Introduction}

In this study, we evaluate intraobserver and interobserver reliability for physiotherapists using the concepts of the International Classification of Impairments, Disabilities, and Handicaps (ICIDH) ${ }^{1}$ to assess a patient's functional status. In rehabilitative medicine, the concepts and terminology of the ICIDH are increasingly being adopted because this classification offers an excellent conceptual framework to assess a patient's functional status. ${ }^{26}$ With the ICIDH, it is possible to describe and evaluate the functional status of a patient at different levels: the tissue-organ-organ system level (impairments), the personal level (disabilities), and the societal level (handicaps).

In primary care, the physiotherapist relies on the patient's history and examination, and other information (diagnosis and referral data), to make an assessment of the patient's functional status. The physiotherapist's ability to reliably assess patient status is important, since medical information (diagnosis and referral data) by itself is often an inadequate starting point for physiotherapy intervention. ${ }^{5-10,16-24}$ The treatment goals in physiotherapy are often aimed at the restoration or preservation of a patient's functional status, thereby contributing to the patient's quality of life. ${ }^{17,18}$ Analysis and evaluation of a patient's functional status is especially important when the relationship between a disorder or äisease and̀ perceived hearth status is iess evident. ${ }^{2527}$ For example, research has shown that there is no longitudinal relationship between the experienced health status and the severity of obstruction of the airways (forced expiratory volume in 1 second) in patients with chronic obstructive pulmonary disease. ${ }^{26}$ Furthermore, outcome studies have been almost exclusively concerned with measuring the outcome of medical care, with few attempts made to assess the contributions by rehabilitative medicine and other health professions..$^{3.4 .8}$

In the Dutch health care system, approximately two thirds of all physiotherapists work in primary health care. ${ }^{13.28}$ The majority of the patients in primary health care (about $80 \%$ ) are referred by general practitioners after being seen for complaints of the musculoskeletal system and the nervous system, ${ }^{12-14}$ with these complaints most often resulting in problems with locomotion. The assessment form that we used to examine reliability in this study was designed as a generic tool for assessing impairments and disabilities. Relevant impairments and disabilities were selected on the basis of other projects that had made use of the ICIDH ${ }^{5.6,8-15}$ Pertinent findings, such as impairments, location of impairment, and disabilities, are recorded following the history taking and physical examination. A manual has been developed to facilitate use of the assessment form.

The methodological prerequisites that have to be met by an assessment form are standardization, reliability, validity, and sensitivity to change (responsiveness). ${ }^{29.30}$ Reliability is a measure of agreement (consistency) and refers to reproducibility of measurement results, or precision of measurements or outcomes. 
We examined the intraobserver and interobserver reliability of these assessments. Each impairment and disability was assessed as "present" (observed or identified), "not present," or "not applicable."

To determine the reliability of the assessments, the following questions had to be answered:

1. How reproducible is the assessment of the separate impairments and disabilities recorded by one therapist for the same patient (intraobserver agreement)?

2. To what extent do two therapists agree when they independently assess the same patient in terms of impairments and disabilities (interobserver agreement)?

\section{Methods}

\section{Assessment Form}

The assessment form used in this study has a two-level structure. The first level deals with 36 impairments based on the chapters of the Classification of Impairments from the Proposal for Adjustment of the ICIDH. ${ }^{5.31}$ The therapist assesses whether an impairment is present, and indicates its severity (on a three-point Likert scale). In addition, the location (body region) and affected organ or tissue of each impairment are recorded. In the Proposal for Adjustment of the ICIDH, an impairment is defined as: "a loss or deviation of an anatomical structure or a physiological or psychological function, taking into consideration the age of a person. ${ }^{15.31}$

The second level consists of 27 disabilities, which are taken from the chapters of the Classification of Disabilities from the Proposal for Adjustment of the ICIDH. ${ }^{3.31}$ The presence and severity are recorded in the same way as for the impairments. In the Proposal for Adjustment of the ICIDH, disability is defined as "a loss or deviation, in both a qualitative and quantitative way, of activity performance or behavior of a person, taking into consideration age, gender, and the physical, social and cultural environment. ${ }^{5.31}$

\section{Design}

The reliability study was carried out as part of the study "Physiotherapist's Consultation in General Practice: an observational study", in which a random sample of 62 physiotherapists from 62 private practices in four different regions of the Netherlands participated (target sample of physiotherapists $=1,533$ ). ${ }^{32}$ For the intraobserver reliability segment of the study, one physiotherapist (in practice A) was randomly selected from the study sample. For the interobserver reliability segment of the study, two pairs of physiotherapists (in practice B and C) were randomly selected from the study sample. 


\section{Intraobserver reliability}

The characteristics of the physiotherapist in practice A (PT A) are shown in Table 1. A total of 33 patients were assessed twice by this physiotherapist. In an effort to minimize recall bias, the patients were separated into three groups of 11 patients. Following the initial evaluation, all patients were re-evaluated two days later by the same physiotherapist.

The patients were seen in a different order than during the initial evaluation and the physiotherapist was blinded to the results of the previous evaluation. The patients received no physiotherapy treatment between the two evaluations.

\section{Interobserver reliability}

In each private physiotherapy practice (practices B and C), a pair of physiotherapists participated (PTs B1 and B2, and PTs $\mathrm{C} 1$ and $\mathrm{C} 2$ ). To assess interobserver reliability, each pair of physiotherapists independently assessed a series of patients. Three of the therapists (PTs B1, B2, and C1) were trained in the use of the assessment form, the theoretical background for the terminology of the ICIDH, and the definitions of selected items used in the assessment form.

The training also consisted oral explanations (by authors EH and JB and research associates) and written explanations of the impairments and disabilities items included in the assessment form. Practical experience in the use of the assessment form was gained during the two months prior to the study. During this time, the therapists completed the assessment form for at least five patients, and had the opportunity to comment on and discuss any problems they had experienced with the form. In practice $B$, the physiotherapists discussed with each other the patient assessment performed during this training period. Oral feedback was provided by authors EH and JB and research associates after the first month and at the end of the training period. The fourth physiotherapist (PT C2) was not included in the training in order to allow us to investigate the influence of training on reliability. The characteristics of the physiotherapists are given in Table 1.

In the interobserver reliability segment of the study, patients were evaluated by one of the two therapisis within a practice. Findings were recorded after the therapist had taken the patient's history and had performed the physical examination. Within three days, the other therapist examined the same patient. Forty patients were assessed in practice B, and 41 patients were assessed in practice $C$. The patients did not receive any treatment between the sessions.

\section{Patients}

All new patients referred to the private practices were candidates for the study. Prospective subjects received written and verbal information about the study. Patients were excluded from the study: if they did not want to participate, if the nature of their complaints did not allow a second examination (e.g., severe acute complaints or disorders such as reflex sympathetic dystrophy), or when treatment (from the physiotherapist's point of view) could not be postponed (e.g., acute ankle sprain, severe acute tension headache). 
Table I. Characteristics of the physiotherapists (PTS)

\begin{tabular}{|c|c|c|c|c|c|}
\hline & \multirow{2}{*}{$\begin{array}{l}\text { Practice A } \\
\text { PT A }\end{array}$} & \multicolumn{2}{|c|}{ Practice B } & \multicolumn{2}{|l|}{ Practice C } \\
\hline & & PT BI & PT B2 & PT Cl & PT $\mathrm{C} 2$ \\
\hline Gender & Female & Male & Female & Female & Female \\
\hline Year graduated & 1990 & 1979 & 1975 & 1974 & 1986 \\
\hline Experience ${ }^{2}(y)$ & 1 & $>10$ & $>10$ & 2 & 7 \\
\hline $\begin{array}{l}\text { Postgraduate } \\
\text { education }\end{array}$ & $\begin{array}{l}\text { Movement } \\
\text { sciences }\end{array}$ & $\begin{array}{l}\text { Manual } \\
\text { therapy } \\
\text { Sports } \\
\text { physiother. }\end{array}$ & $\begin{array}{l}\text { Manual } \\
\text { therapy } \\
\text { Sports } \\
\text { physiother. }\end{array}$ & $\begin{array}{l}\text { Manual } \\
\text { therapy } \\
\text { Neurodevelopmental } \\
\text { treatment (NDT) } \\
\text { Cardiac } \\
\text { rehabilitation }\end{array}$ & \\
\hline $\begin{array}{l}\text { Training in use } \\
\text { of assessment } \\
\text { form }\end{array}$ & Yes & Yes & Yes & Yes & No \\
\hline
\end{tabular}

Years of experience in primary health care

Recognized by the Royal Dutch Physical Therapy Association (KNGF)

All selected subjects gave their written consent prior to participation in the study. The medical diagnosis was classified using the International Classification of Primary Care $(\mathrm{ICPC}) .^{33}$

\section{Data analysis}

The data analysis consisted of a description of the demographic and referral data of the patients and the analysis of the reliability of the categorization of impairments and disabilities as being present or not present by one therapist in the intraobserver reliability segment of the study and by both pairs of physiotherapists in the interobserver reliability segment of the study. The prevalence of the observed or identified impairments and disabilities was described by frequency distributions. Agreement was determined by the percentage of agreement (i.e., the number of patients on which the observers agreed as a proportion of all patients studied) and Cohen's kappa $(k)$. The agreement within and between therapists was calculated separately for each impairment and disability (2x2 table). An impairment were included in the analysis only when the first and second assessments determined the same anatomical location for the impairment. When more than one location of impairment was determined, only the first mentioned (primary) location of the impairment was included in the analysis.

Cohen's kappa, as opposed to percentage of agreement, is a chance-corrected estimate of agreement. Kappa indicates the actual agreement as a proportion of the potential agreement following correction for chance agreement. ${ }^{29.30 .34 .35}$ The value of Cohen's kappa may vary between 1 (perfect agreement) and -1 (less agreement than can be expected on the basis of chance alone). For the interpretation of kappa, the classifications of Van Triet et $\mathrm{al}^{11}$ and Fleiss ${ }^{39}$ have been used. In their opinion, a value greater than .75 indicates 
"excellent" agreement, a value between .40 and .75 indicates "fair to good" agreement (in our terminology, "satisfactory" agreement), and a value less than .40 indicates "poor" agreement.

For the purpose of our study, a percentage of agreement greater than $75 \%$ was considered sufficient." For example, a high percentage of agreement can be present while the corresponding value of kappa is very low, or kappa can increase unexpectedly for identical percentages of agreement when there is not a spread in the distribution of judgments. ${ }^{36,37}$ In the absence of criteria relating kappa for the kappa skewness of observations, we adopted the guidelines proposed by Van Triet et al. " Kappa was not calculated if each of the impairments or disabilities was identified in less than $10 \%$ or more than $90 \%$ of the patients. In that case, only the percentage of agreement is given, but these values may be inflated by chance agreement, and need to be interpreted cautiously.

The kappa value should be interpreted with caution if each of the impairments or disabilities is identified in $10 \%$ to $20 \%$ or $80 \%$ to $90 \%$ of the patients, because without a widespread distribution of possible judgments, kappa values tend to be very low, and not necessarily reflect the agreement that can be seen in a more diverse group.

\section{Results}

\section{Patients}

Thirty-three patients (16 men, 17 women), with a mean age of 38.3 years ( $\mathrm{sd}=10.6$, range $=18-56$ ), participated in the intraobserver reliability segment of the study. The most frequent reasons for their referral for physiotherapy were low back complaints or disorders, and complaints involving the thigh, hip or leg.

Eighty-one patients participated in the interobserver reliability segment of the study. Forty patients ( 22 women, 18 men) with a mean age of 41.5 years $(\mathrm{sd}=5.4$, range $=22-45)$, participated in practice B. Forty-one patients (22 women, 19 men), with a mean age of 41.8 years $(\mathrm{sd}=9.2$, range $=22-55)$ participated in practice $\mathrm{C}$. In practice $\mathrm{B}$, most patients were referred with the diagnosis of low back complaints, and osteoarthritis of the spine. In practice $\mathbf{C}$, mosi patients were referred with diagnoses of low back complaints, and neck and shoulder complaints. Table 2 presents descriptive data for the patients and their medical diagnosis, as classified with the ICPC. ${ }^{33}$ 
Table 2. Characteristics of patients

\begin{tabular}{|c|c|c|c|c|}
\hline \multirow[t]{2}{*}{ Patient characteristic } & \multirow[t]{2}{*}{ ICPC code" } & \multirow{2}{*}{$\begin{array}{l}\begin{array}{l}\text { Intraobserver } \\
\text { reliability }\end{array} \\
\text { Practice A }\end{array}$} & \multicolumn{2}{|c|}{$\begin{array}{l}\text { Interobserver } \\
\text { reliability }\end{array}$} \\
\hline & & & Practice B & Practice C \\
\hline \multicolumn{5}{|l|}{ Gender } \\
\hline Male/Female & & $16 / 17$ & $18 / 22$ & $19 / 22$ \\
\hline \multicolumn{5}{|l|}{ Age $(y)$} \\
\hline Mean (sd) & & $38.3(10.6)$ & $41.5(5.4)$ & $41.8(9.2)$ \\
\hline Range & & $18-56$ & $22-45$ & $22-55$ \\
\hline \multicolumn{5}{|l|}{ Medical diagnosis (ICPC) } \\
\hline Neck complaints & L01 & 2 & 8 & 7 \\
\hline Back complaints & LO2 & 2 & & 2 \\
\hline $\begin{array}{l}\text { Low back complaints. } \\
\text { (no radiating pain) }\end{array}$ & L03 & 7 & 10 & 11 \\
\hline $\begin{array}{l}\text { Low back complaints } \\
\text { (radiating pain) }\end{array}$ & L.86 & 3 & 2 & 1 \\
\hline Shoulder complaints/syndromes & L08/L92 & 3 & $a$ & 7 \\
\hline Arms/elbow complaints & Lo9 & 2 & 2 & 2 \\
\hline Wrist/hand/finger complaints & $\mathrm{L} 11 / \mathrm{L} 12$ & 2 & 2 & \\
\hline Hip/leg/thigh complaints & L.13/L14/L75 & 4 & 1 & \\
\hline Knee complaints & L15/L96 & 2 & 4 & 2 \\
\hline Ankle/foot/toe complaints & LI6/L17 & 2 & & 2 \\
\hline Arthrosis/spondylosis spine & $\mathrm{L} 84$ & 2 & 6 & 2 \\
\hline Coxarthrosis & L89 & & & 2 \\
\hline Other & $\begin{array}{l}\text { N02/N94/S93 } \\
\text { L04/L81/L94 }\end{array}$ & 2 & 1 & 3 \\
\hline Total & & 33 & 40 & 41 \\
\hline
\end{tabular}

* International Classification of Primary Care (ICPC) ${ }^{\mu 1}$

\section{Intraobserver reliability}

The percentage of agreement and kappa values for intraobserver reliability are presented in Tables 3 and 4 . Table 3 shows that 22 of the 36 impairments were assessed; 13 items were assessed for more than $20 \%$ of the patients, and 5 items were recorded in less than $10 \%$ or more than $90 \%$ of the patients. For 18 of the 22 impairments, the percentage of agreement was greater than $75 \%$ (range $=76 \%-97 \%$ ). Fifteen of the 17 impairments for which kappa values were calculated showed fair to good, or excellent agreement (range $=.40-.91)$. Four impairments were assessed between $10 \%$ and $20 \%$ of the patients or between $80 \%$ and $90 \%$ of the patients, which means that the results should be interpreted with caution.

The results for disabilities were more consistent. Twenty of the 27 disabilities were assessed; 10 items were assessed for more than $20 \%$ of the patients, and 4 items were recorded for less than $10 \%$ or more than $90 \%$ of the patients. They all showed greater than $75 \%$ agreement (range $=77 \%-94 \%$ ). Kappa values could not be calculated for four 
disabilities (prevalence of $<10 \%$ or $>90 \%$ ). The remaining 16 disabilities showed fair to good, or excellent agreement (range $=.52-.81$ ).

In summary, 42 of the 63 items (impairments and disabilities) on the assessment form $(67 \%)$ were assessed. Four of the items did not meet the criterion value of greater than $75 \%$ agreement. Kappa values could be calculated for 33 items. For $2(6 \%)$ of these 33 items, there was poor agreement.

\section{Interobserver reliability}

Interobserver reliability differed between the two practices (Tables 3 and 4). Seventeen of the 36 impairments were assessed in patients in practice $B$, and 24 of the impairments were assessed in patients in practice $\mathrm{C}$.

The 17 impairments that were assessed in practice B all showed relatively high levels of agreement ( $>75 \%$, range $=78 \%-95 \%)$. For two impairments, kappa values could not be calculated. All impairments that were assessed, except "impairment in joint position," had kappa values in the "fair to good" or "excellent" range (.41-.80). "Impairment in joint position" showed "poor" agreement $(.26)$ but the percentage of agreement was sufficient (78\%). In practice C, $8(33 \%)$ of the 24 impairments assessed showed a percentage of agreement greater than $75 \%$ (range $=80 \%-93 \%$ ). Kappa values could be calculated for 19 of these 24 impairments. Three impairments for which kappa values could be calculated showed "satisfactory" or "excellent" agreement (range $=.41-.84$; "pain during movement," "impairment in gait," and "edema"). Sixteen of the impairments for which kappa values could be calculated showed poor agreement (range $=-.47-.33$ ). Eight impairments had a negative kappa value, indicating that agreement was lower than could be expected on the basis of chance.

The results for findings of disabilities showed the same differences between practices $\mathrm{B}$ and C (Table 4). In practice B 20 of the 27 disabilities were assessed. The percentage of agreement varied between $70 \%$ and $95 \%$. Four disabilities ("disability in changing body posture," "disability in lifting," "disability in picking up," and "disability in bending over") did not meet the criterion value. Kappa values could not be calculated for one disability. There was poor agreement for three disabilities.

For three disabilities with less than $75 \%$ agreement, there was "fair to good" agreement when the percentage-of-agreement values were corrected for chance (satisfactory kappa, low percentage of agreement). The reverse happened for "disability in pushing" and "disability in reaching."

In practice C, 23 of the 27 disabilities were assessed. For 11 of these 23 disabilities, percentage of agreement was greater than $75 \%$. Kappa values could not be calculated for two disabilities. The remaining disabilities had kappa values between -.25 and .72 . Thirteen disabilities showed poor agreement. Eight disabilities had fair to good kappa values (range $=.47-.72$ ). 
Table 3. Percentage-of-Agreement ( $\%$ A) and kappa values $(k)$ for assessments of impairments

\begin{tabular}{|c|c|c|c|c|c|c|}
\hline \multirow[b]{3}{*}{ Impairments } & \multirow{2}{*}{\multicolumn{2}{|c|}{$\begin{array}{l}\begin{array}{l}\text { Intraobserver } \\
\text { reliability }\end{array} \\
\text { Practice A }\end{array}$}} & \multicolumn{4}{|c|}{ Interobserver reliability } \\
\hline & & & \multicolumn{2}{|c|}{ Practice B } & \multicolumn{2}{|c|}{ Practice C } \\
\hline & $\% \mathrm{~A}$ & $k$ & $\$ \mathrm{~A}$ & $k$ & $\approx \mathrm{A}$ & $k$ \\
\hline 1. Pain & 94 & .64 & $\bullet$ & $\bullet$ & $\bullet$ & $\bullet$ \\
\hline 2. Pain following movement & 88 & .41 & 85 & .67 & 66 & .32 \\
\hline 3. Pain during movement & 76 & .34 & 95 & $.80 !$ & 80 & .411 \\
\hline 4. Pain at rest & 70 & .18 & 83 & .65 & 66 & .33 \\
\hline 5. Pain during static stress & 73 & .46 & 83 & $48 !$ & 63 & .18 \\
\hline 6. Pain sensation & 79 & .45 & 88 & $.48 !$ & 39 & -.23 \\
\hline 7. Pain behavior & 88 & $.65 !$ & 93 & .781 & 83 & $\cdot$ \\
\hline 8. Decreased range of motion & 82 & .63 & 92 & $.75 !$ & 73 & $10 !$ \\
\hline 9. Increased range of motion & - & $\bullet$ & $\bullet$ & $\bullet$ & 98 & . \\
\hline 10. Impairment in gait & 91 & .79 & 85 & .60 & 83 & .52 \\
\hline 11. Decreased active stability & 88 & .71 & 93 & $.78 !$ & 44 & -.15 \\
\hline 12. Decreased passive stability & - & $\bullet$ & - & $\bullet$ & 68 & -19 \\
\hline 13. Impairment in coordination & 82 & .411 & - & $\bullet$ & 51 & -.24 \\
\hline 14. Increased resting tone (muscle) & 70 & 40 & 83 & .57 & 61 & .20 \\
\hline 15. Decreased resting tone & 85 & . & $\bullet$ & $\bullet$ & $\bullet$ & $\bullet$ \\
\hline 16. Impairment in proprioception & $\bullet$ & $\bullet$ & 88 & $.41 !$ & 80 & - \\
\hline 17. Ipairment in kinesthesia & $\bullet$ & $\bullet$ & - & - & 56 & -.19 \\
\hline 18. Impairment in muscle strength & 73 & .46 & 85 & $.41 !$ & 53 & -.47 \\
\hline 19. Trophic impairment & 82 & .54 & 85 & $.47 !$ & 56 & $-.09 !$ \\
\hline 20. Impairment in body posture & 85 & .46 & 83 & .59 & 73 & .30 \\
\hline 21. Impairment in joint position & 94 & $.80 !$ & 78 & $.26 !$ & 56 & -.01 \\
\hline 22. Impairment in pliability of skin & $\bullet$ & $\bullet$ & 85 & $\cdot$ & 63 & .27 \\
\hline 23. Impairment in sensibility & 82 & - & $\bullet$ & $\bullet$ & - & $\bullet$ \\
\hline 24. Impairment in circulation & 91 & . & $\bullet$ & $\bullet$ & - & $\bullet$ \\
\hline 25. Edema & 97 & $91 !$ & $\bullet$ & $\bullet$ & 95 & $.84 !$ \\
\hline $\begin{array}{l}\text { 26. Impairment in mucus } \\
\text { production/transport }\end{array}$ & $\bullet$ & $\bullet$ & $\bullet$ & $\bullet$ & - & $\bullet$ \\
\hline 27. Impairment in respiration & $\bullet$ & $\bullet$ & $\bullet$ & $\bullet$ & $\bullet$ & $\bullet$ \\
\hline 28. Impairment in respiratory movement & $\bullet$ & $\bullet$ & $\bullet$ & - & - & $\bullet$ \\
\hline 29. Impairment in continence & $\bullet$ & $\bullet$ & $\bullet$ & $\bullet$ & $\bullet$ & $\bullet$ \\
\hline $\begin{array}{l}\text { 30. Intellectual and psychological } \\
\text { impairments }\end{array}$ & 97 & . & $\bullet$ & - & 80 & - \\
\hline 31. Eye and visual impairments & $\bullet$ & $\bullet$ & $\bullet$ & $\bullet$ & $\bullet$ & $\bullet$ \\
\hline 32. Ear and hearing impairments & $\bullet$ & $\bullet$ & $\bullet$ & $\bullet$ & $\bullet$ & $\bullet$ \\
\hline 33. Impairments in balance & $\bullet$ & $\bullet$ & $\bullet$ & $\bullet$ & $\bullet$ & $\bullet$ \\
\hline 34. Dizziness & $\bullet$ & $\bullet$ & 95 & $=$ & - & $\bullet$ \\
\hline 35. Tiredness & 76 & - & $\bullet$ & $\bullet$ & 68 & - \\
\hline 36. Other impairments & $\bullet$ & $\bullet$ & $\bullet$ & $\bullet$ & 83 & .17 \\
\hline
\end{tabular}

- Not applicable.

- Kappa cannot be calculated (impairment of $<10 \%$ or $>90 \%$ of patients). Kappa $<.40=$ poor agreement: kappa between .40 and $.75=$ fair to good agreement; kappa $>.75=$ excellent agreement

! Contents of cells between $10 \%$ and $20 \%$ of between $80 \%$ and $90 \%$ 
In summary, 37 (59\%) of the 63 items (impairments and disabilities) in practice B and 47 (75\%) of the 63 items in practice $C$ were assessed. What we considered an acceptable percentage of agreement $(>75 \%)$ was not found for $4(11 \%)$ of the 37 items assessed in practice B and for $28(60 \%)$ of the 47 items in practice C.

Kappa values could be calculated for $34 \mathrm{titems}$ in practice B, and for 40 items in practice C. Poor agreement, in our view, was found for 4 items (12\%) in practice B and 29 items $(74 \%)$ in practice $\mathrm{C}$ when the agreement values (\% $\mathrm{A}$ ) were corrected for chance.

\section{Comment}

Based on the kappa values, the intraobserver reliability segment of the study showed that impairments and disabilities could be reliably assessed with exception of three impairments ("pain at rest," "pain during movement," and "increased resting tone of a muscle"). Without exception, however, disabilities were recorded, in our view, with an acceptable level of reliability. Our results compare: well with the results of similar studies in which patients' functional status was assessed for various health care professions. ${ }^{11.15,38-43}$

In our study, the different aspects of pain showed generally poor agreement. Epidemiological studies ${ }^{12.44}$ show that there is widespread prevalence of pain, and suggest that pain is one of the most important impairments at which physiotherapy interventions are directed. Operationally defining pain remains difficult because different dimensions of pain need to be assessed. Bakx et $\mathrm{al}^{15}$ have shown that pain can be reliably assessed when pain is related to specific dimensions of disability. Furthermore, Van der Kloot et $\mathrm{al}^{44}$ have shown that pain can be assessed reliably when different domains of pain (e.g., sensory, emotional-affective, cognitive-evaluative) are assessed. We believe, therefore, that expansion of the assessment form is needed to include other categories and dimensions of pain.

The results of the interobserver reliability segment of the study are difficult to interpret and appear to be contradictory. Based on the kappa values in practice B, there was "fair to good" or "excellent" agreement at the level of impairments, with the exception of "impairment in joint position." At the level of disabilities, the study indicates that most disabilities can be reliably recorded, although some items showed a high percentage of agreement and poor kappa, and vice versa ("disability in pushing," and "disability in reaching"). We conclude that on the basis of the results in practice $B$, the interobserver reliability of the analysis of the patients' functional status is satisfactory.

In practice $\mathrm{C}$, agreement was generally poor. The differences in results between the two pairs of therapists, in our opinion, can largely be explained by the differences in characteristics of the physiotherapists. First, the therapists in practice $\mathrm{C}$ showed a difference in areas of interest, based on their post-graduate education. Second, there was a great difference in years of experience in working in a primary health care setting. 
Table 4. Percentage-of-Agreement (\% A) and kappa values (k) for assessments of disablitities

\begin{tabular}{|c|c|c|c|c|c|c|}
\hline \multirow[b]{3}{*}{ Disabilities } & \multirow{2}{*}{\multicolumn{2}{|c|}{$\begin{array}{l}\begin{array}{l}\text { Intraobserver } \\
\text { reliability }\end{array} \\
\text { Practice A }\end{array}$}} & \multicolumn{4}{|c|}{ Interobserver reliability } \\
\hline & & & \multicolumn{2}{|c|}{ Practice B } & \multicolumn{2}{|c|}{ Practice C } \\
\hline & \% A & $k$ & $\approx \mathrm{A}$ & $k$ & $\% \mathrm{~A}$ & $k$ \\
\hline \multicolumn{7}{|c|}{ Disability in sensory motor skills } \\
\hline 1. Maintaining postures & 90 & $.71 !$ & 90 & .73 & 73 & $.26 !$ \\
\hline 2. Changing postures & $\bullet$ & $\bullet$ & 73 & .45 & 68 & 11 \\
\hline 3. Carrying & 77 & .55 & 76 & .46 & 78 & .57 \\
\hline 4. Lifting & 77 & .55 & 72 & .43 & 76 & .52 \\
\hline 5. Picking up & 90 & .67 & 70 & $.21 !$ & 66 & .31 \\
\hline 6. Pulling & 84 & $\cdot$ & 76 & .41 & 63 & .11 \\
\hline 7. Pushing & 90 & * & 76 & $.39 !$ & 61 & 01 \\
\hline 8. Reaching & 94 & . & 76 & .151 & 71 & .38 \\
\hline 9. Moving objects & 77 & .55 & 85 & $.57 !$ & 63 & -.25 \\
\hline 10. Handling objects & $\bullet$ & $\bullet$ & 88 & $.59 !$ & 54 & -.22 \\
\hline I1. Grasping & 94 & .711 & $\bullet$ & $\bullet$ & 63 & .17 \\
\hline 12. Squatting & 86 & .68 & 93 & $.72 !$ & 73 & .34 \\
\hline 13. Kneeling & 89 & $67 !$ & 95 & .771 & 83 & .52 \\
\hline 14. Bending over & 94 & . & 75 & .48 & 80 & 59 \\
\hline 15. Crawling & 93 & $.76 !$ & $\bullet$ & $\bullet$ & 88 & - \\
\hline 16. Other & $\bullet$ & $\bullet$ & $\bullet$ & $\bullet$ & $\bullet$ & $\bullet$ \\
\hline \multicolumn{7}{|l|}{ Disabilities in locomotion } \\
\hline 17. Walking & 90 & .81 & 90 & .79 & 85 & $.59 !$ \\
\hline 18. Climbing stairs & 81 & .54 & 90 & $.69 !$ & 90 & $.72 !$ \\
\hline 19. Cycling & 86 & $.52 !$ & 89 & $.68 !$ & 85 & .57 \\
\hline 20. Other & 87 & $.52 ?$ & 93 & - & 78 & $18 !$ \\
\hline \multicolumn{7}{|c|}{ Disabilities in complex skills } \\
\hline 21. Personal care & $\bullet$ & $\bullet$ & $\bullet$ & $\bullet$ & 90 & - \\
\hline 22. Domestic activities & 87 & .75 & 90 & .78 & 76 & .47 \\
\hline 23. Related to work & 84 & .57 & 90 & .80 & 60 & .20 \\
\hline 24. Related to recreation & 85 & .70 & 90 & .79 & 51 & .03 \\
\hline 25. Psychosocial skills & $\bullet$ & $\bullet$ & $\bullet$ & $\bullet$ & $\bullet$ & $\bullet$ \\
\hline 26. Communication & $\bullet$ & $\bullet$ & - & $\bullet$ & $\bullet$ & $\bullet$ \\
\hline 27. Other & $\bullet$ & $\bullet$ & - & $\bullet$ & - & $\bullet$ \\
\hline
\end{tabular}

- Not applicable.

- Kappa cannot be calculated (disability of $<10 \%$ or $>90 \%$ of patients). Kappa $<.40=$ poor agreement; kappa berween! .40 and $.75=$ fair to good agreement; kappa $>.75=$ excellent agreement

1. Contents of cells between $10 \%$ and $20 \%$ or between $80 \%$ and $90 \%$ 
Third, and in our opinion probably the most important factor, one of the physiotherapist in practice $C$ had not received any formal instruction in the use of the registration form. This seems to be supported by the fact that there are a number of negative kappa values. A negative kappa can be interpreted as a negative correlation-coefficient. In this study, this interpretation would mean that the first physiotherapist assessed an impairment or disability as "present" and the second therapist assessed the same impairment or disability as "not present." These extreme disagreements (less agreement than can be expected on the basis of chance alone) between the two observers could be caused by a physiotherapist's lack of experience or unfamiliarity with the form, as was the case with one of the physiotherapists.

Extreme disagreement may also be caused by an insufficient description of the item in the manual for the assessment form. Therefore, in addition to instruction in the use of the form, a definition of terms, and the proper description of impairments and disabilities in the Proposal for Adjustment of the ICIDH seem to be important. In view of the limited number of participating therapists, our conclusions must be viewed with some caution until more data are available.

Van Triet et al ${ }^{11}$ observed that there was greater agreement for the assessments of disabilities than for the assessments of impairments. This observation could be explained by the fact that the included items of disabilities on the assessment schedule of Van Triet et al $^{11}$ were less specific than those listed on the form used in our study.

A disease-specific form (e.g., for assessing the functional health status of patients following a stroke) would include other items. Our assessment form was developed as a generic instrument to be used by physiotherapists for patients in primary health care. More than $90 \%$ of the patients referred for primary health care, however, are patients with complaints involving the musculoskeletal system. ${ }^{12-14}$

The level of detail of information may influence the reliability of a functional assessment. ${ }^{5}$ The assessment form used in our study is based on the Proposal for Adjustment of the ICIDH, in which abilities and disabilities have been hierarchically classified in great detail ${ }^{5.31}$ In our hierarchical classification, there is a step-by-step ordering of concepts into general (less-detailed) classes that are further subdivided into more detailed subclasses. Assessments at a lower hierarchical level (subclasses with a higher level of detail) may influence the reliability. An increase in detail, therefore, could be accompanied by a decrease in reliability. This possible disadvantage should be weighted against the advantage of having more specific information. The only conclusive way of determining the effect of greater detail will be further research. There are indications, however, that this may not be the case when the form is constructed on the basis of the Proposal for Adjustment of the ICIDH ${ }^{5.31}$

Our assessment form was developed as a generic instrument for physiotherapists in primary health care settings. For patient populations with more specific problems, depending on the purpose of the assessment form, more specific information on impairments (including anatomic location and involved tissues) and disabilities may be needed. We believe that this information is especially important at the levell of 
impairments. In our view, it would be advisable to operationally define the terms "impairment" and "disability" in the Proposal for Adjustment of the ICIDH to stimulate and enhance the uniformity of professional language.

The results of our study suggest that the reliability of determinations of selected impairments and disabilities may be sufficient for some survey research and for the general description of the physiotherapy process (practice patterns).

It is very important for physiotherapy practice to classify the functional status of patients more explicitly. Treatment objectives can be described in an unequivocal way, and homogeneous patient groups can be composed on the basis of similar impairments (including anatomic location and involved tissues), and disabilities, to evaluate the outcome of treatment interventions.

With regard to the design and overall outcomes of our study, it should be noted that there might be some real changes in impairments and disabilities during the time intervals between the first and second observations (intraobserver reliability) or between the first and second observers (interobserver reliability). For practical reasons, there was a maximum duration of 2 and 3 days for the intraobserver and interobserver segments of the study respectively. Theoretically, the severity of the impairments and disabilities might have changed within 3 days. However, because the study was carried out with new patients without any treatment being provided between the 2 observations, and the data were analyzed on a less-detailed dichotomous level ("not present" versus "present"'), it is very unlikely that the time interval could have greatly affected the outcome.

Kappa values are affected by prevalence of the identified (observed) impairments and disabilities. ${ }^{11.45}$ In those instances with a prevalence of less then $10 \%$ or more then $90 \%$ kappa may not be calculated. ${ }^{11.45}$ In our study, some contradictory findings were observed between percentage of agreement and kappa values because of problems with the distributions of findings. Cicchetti ${ }^{36}$ and Feinstein ${ }^{37}$ discuss two paradoxes of kappa based on a $2 \times 2$ Table. The first paradox concerns a high agreement with poor kappa. In relation to the first paradox, kappa could increase with the same percentage of agreement (paradox 2). This apparent contradiction occurred several times in our study. For example, if one physiotherapist assesses an impairment as present in 3 of 50 patients and as not present in the other 47 patients while another physiotherapist assesses the impairment as present in 1 patient and as not present in 49 patients, the kappa value would be 49 . If both physiotherapists, however, assess the same impairment as present in 3 patients and as not present in 47 patients, the kappa value would be 1.00. For further discussion of this matter, see Cicchetti and Feinstein. ${ }^{36,37}$

In our study, the physiotherapists were asked to indicate the severity of an impairment or disability on a three-point Likert scale. By using the weighted kappa, the degree of agreement can be calculated with more precision. Use of weighted kappa with four ordered categories (e.g. "not present" and "not applicable" versus "present" on a threepoint Likert scale), however, requires a prevalence per item of 20 patients. ${ }^{46}$ 
In our study, many items did not meet this criterion; consequently, weighted kappa values were not calculated for these items.

\section{Conclusion}

Our results show that the intraobserver and interobserver reliability of the assessment form can fall within a range that many consider to be satisfactory for scientific investigation and survey research, and for physiotherapy practice, provided that necessary training is given. For some items (e.g., pain), however, the assessment form may need to be improved with the addition of more specific dimensions. Before definite statements on reliability can be made, however, data from more therapists in more practices and with more patients are needed. Although the conceptual framework of the ICIDH offers physiotherapists opportunities to describe a patient's functional status, it should be emphasized that the assessment form we examined can be used only to approximate the severity of a patient's health problem (indirectly) based on the judgment of the physiotherapist. Nevertheless, in our opinion, an inventory of impairments and disabilities can be used by therapists to formulate priorities and treatment goals. It can also be used for determining the prognosis for outcome and for determining the total number and frequency of treatment sessions (practice patterns). Although the interventions by physiotherapists are usually not directed at the handicap level (social participation), the effects of the interventions at the impairment and disability leveis may also result in changes at the handicap level.

\section{References}

1. World Health Organization. ICIDH, International Classification of Impairments, Disabilities, and Handicaps: a manual of classification relating to the consequences of disease. Geneva: WHO, 1980.

2. Nagi SZ. In: Granger CV. A conceptual model for functional assessment. In: Granger CV, Gresham GE (editors). Functional assessment in rehabilitation medicine. Baltimore, Williams \& Wilkins, 1984:15-25.

3. Wilkin D, Hallam L, Doggett M. Measures of need and outcome for primary health care. Oxford: Oxford University Press, 1992.

4. Whyte J. Toward a methodology for rehabilitation research. Am J Phys Med Rehabil. 1994:73:428-435.

5. Heerkens YF, Brandsma JW, Lakerveld-Heyl K, Ravensberg van CD. Impairments and disabilities - The difference. Proposal for Adjustment of the International Classification of Impairments, Disabilities, and. Handicaps. Phys Ther, 1994;74:430-442.

6. Dekker J, van Baar ME, Curfs EChR, Kerssens JJ. Diagnosis and treatment in physical therapy: an, investigation of their relationship. Phys Ther. 1993; 73:568-580.

7. Jette AM. Outcomes research: shifting the dominant research paradigm in physical therapy. Phys Ther. $1995 ; 75: 965-970$.

8. Enderby P, Kew E. Outcome measurement in physiotherapy using the World Health Organisation's. Classification of Impairment, Disability and Handicap: A pilot study. Physioth. 1995:4(81):177-180.

9. Mischner-van Ravensberg CD, Paauw HJM, Gestel JLM. De fysiotherapeurische werkdiagnose in relatie tot de medische diagnose. Ned T Fysiotherapie. 1988;5:104-107.

10. Hendriks HJM, Wagner C, Brandsma JW, et al. Experiences with physiotherapsist's consultation. Results: of a feasibility study. Physioth Theory and Practice. 1996:12:211-220.

11. Triet EF van, Dekker J. Kerssens JJ, Curfs EChr. Reliability of the assessment of impairments and disabilities in survey research in the field of physical therapy. Int Disabil Stud. 1990;12:61-65. 
12. Valk van der RWA, Dekker J, Boschman M. Basisgegevens extramurale fysiotherapie 1989-1992. Gegevens uit het project "Beleidsgericht Evaluatie- en Effectonderzoek Fysiotherapie (BEEF)". Utrecht: Nivel, 1995.

13. Kerssens JJ, Curfs EChr. Extramurale fysiotherapie. Utrecht: Nivel, 1993 (Dissertation University of Utrecht).

14. Klaveren van AAJ, Hendriks HJM, Oostendorp RAB, et al. Basisgegevens van het Fysiotherapie Ontwikkelings Netwerk. Een inventarisatie van het fysiotherapeutisch handelen in de eerste lijn m.b.v. het Basis Registratieformulier Fysiotherapie. Amersfoort: SWSF, 1995.

15. Bakx VEM, Oostendorp RAB, Elvers JWH, et al. Pijnmeting in de fysiotherapie. Een betrouwbaarheidonderzoek. Ned T Fysiotherapie. 1993:2:60-67.

16. Hulme JB, Wackernagel B, Lewis JW. Communication between physicians and physical therapists. Phys Ther. 1988;68:26-31.

17. Brandsma JW. Heerkens YF, Ravensberg van CD. The International. Classification of Impairments, Disabilities, and Handicaps (ICIDH): a manual of classification relating to the consequences of disease? J Rehab Sciences. 1995:8:2-7.

18. Diagnosis in physical therapy: a roundtable discussion. PT-magazine of physical therapy; June 1993:58-65.

19. Sahrmann SA. Diagnosis and classification by the physical therapist - a prerequisite for treatment: a special communication. Phys Ther. 1988;68:1703-1706.

20. Rose S. Physical therapy diagnosis: role and function. Phys Ther. 1989;69:535-537.

21. Delitto A. Are measures of function and disability important in low back pain? Phys Ther. 1994;74:452. 462.

22. Guccione AA. Physical therapy diagnosis and the relationship between impairments and function. Phys Ther. 1991:71:499-504.

23. Jette AM. Diagnosis and classification by physical therapists. Phys Ther. 1989:69:967-969.

24. Jette AM. Physical disablement concepts for physical therapy research and practice. Phys Ther. 1994;74:380-386.

25. Bindman $A B$, Keane $D$, Lurie N. Measuring health changes among severely ill patients. Med Care. 1990;28:1 1 $142-52$.

26. Schayk van CP, Rutten MPMH, Boom van den G、et al. Longfunctie en ervaren gezondheid bij patiënten met astma en chronisch obstructieve longziekten in longitudinaal onderzoek. Huisarts Wet. 1995;38(3):129131 .

27. Bo K. Stress urinary incontinence, physical activity and pelvic floor muscle strength training (review articie). Scand J Med Sci Sports. 1992;2:197-206.

28. Hingstman L. Harmsen J. Beroepen in de extramurale gezondheidszorg 1994. Aanbod van beroepsbeoefenaren en samenwerkingsverbanden in de extramurale gezondheidszorg in de periode 1980 1993. Utrecht, De Tijdstroom/Nivel, 1994.

29. Sackett DL, Hayes RB, Guyat GH, Tugwell P. Clinical Epidemiology . A basic science for clinical medicine (2e edition). Boston: Little, Brown and Company, 199 1.

30. Bouter LM, Dongen van MCJM. Epidemiologisch onderzoek: opzet en interprezatie. Utrecht: Bohin, Schelterna en Holkema, 1988.

31. Heerkens YF, Brandsma JW, van Ravensberg CD. Proposals for adaptation of the Classification of Impairments and the Classification of Disabilities of the ICIDH from the perspective of five Dutch health professions. Zoetermeer, the: Netherlands: Nationale Raad voor de Volksgezondheid/WHO Collaborating Centre for the ICIDH: 1993.

32. Hendriks HJM, Wagner C, Brandsma JW, Dekker J. Evaluatic varı hel Consultatief Fysiotherapeutisch Onderzoek in de eertse lijn. Resultaten van een veldexperiment. Utrecht: Nivel, 1994.

33. Lamberts H. Wood M. International Classification of Ptimary Care. Oxford: University Press Oxíord, 1987.

34. Cohen J. A coefficient of agreement for nominal scales. Educ Psychol Meas. 1960;20:37-46.

35. Fleiss JL. Statistical methods for rates and proportions (2nd ed). New York: Johrt Wiley, 1981.

36. Cichetti DV, Feinstein AR. High agreement but low kappa: II. resolving the paradoxes. J Clin Epidemiol. 1990:43:551-558.

37. Feinstein AR, Cichetti DV. High agreement but low kappa: 1. The problem of two paradoxes. J Clin Epidemiol. 1990;43:543-549. 
38. Jelles F, Bennekom van CAM, Lankhorst GJ, et al. Inter- and intra-rater agreement of the rehabilitation activities profile. J Clin Epidemiol. 1995;3(48):407-416.

39. Gisbergen MJWM van, Dekker J. Reliability of the diagnosis of impairments and disabilities by excercise therapists. J Rehab Sciences 1992:5:67-73.

40. Gisbergen MJWM van, Dekker J, Zuijderduin W. Reliability of the diagnosis of impairments in survey research in the field of chiropody. Disabil Rehabil. 1993;15:76-82.

41. Driessen MJ, Dekker J, Lankhorst GJ, van der Zee J. Inter-rater and intra-rater reliability of the occupational therapy diagnosis. Occup Ther J Res. 1995;15(4):259-274.

42. Berg J van de, Lankhorst GJ. Inter-rater and intra-rater reliability of disability ratings based on the modified D code of the ICIDH. Int Disabil Stud. 1990:12:20-21.

43. Dekker J. Application of the ICIDH in survey research on rehabilitation: the emergence of the functional diagnosis. Disabil Rehabil. 1995;17:195-201.

44. Kloot van der WA, Oostendorp RAB, Meij van der J, Heuvel van den J. De Nederlandse versie van 'McGili pain questionnaire': een betrouwbare pijnvragenlijst. Ned T Geneesk. 1995;139(13):669-673.

45. Schoutsen HJA. Statistical Measurement of Inter-observer Agreement: Analysis of Agreements and Disagreements Between Observers. Dissertation University of Utrecht. Elinkwijk, 1985.

46. Cichetti DV. Testing the normal approximation and minimal size requirements of weighted kappa when the number of categories is large. Appl Psychol Meas, 1981;5:101-104. 


\section{Physiotherapist's Consultation in General Practice: Objectives, Research Questions, and Design of the Study}

\section{Abstract}

An important issue in health care policy is improvement in the efficiency and quality of care. Within the Dutch primary health care system, physiotherapists are important collaborating partners with general practitioners (GPs) in the management of patients. This is particularly true for patients with disorders and complaints of the locomotor system. Deterrents to optimal collaboration between GPs and physiotherapists have been identified as problems concerning: communication between GPs and physiotherapists, the identification of indications for physiotherapy, and the lack knowledge of GPs about physiotherapeutic possibilities. These problems can, to a large extent, be dealt with when GPs and physiotherapists, while respecting each others' qualifications and competencies, increase their level of cooperation by improving communication. Physiotherapist's consultation, prior to possible referral for treatment, could enhance the quality and efficiency of health care and the professional development of physiotherapy.

The objectives, research questions and design of this study are described in detail in this paper. This allows a critical judgment of the research questions and the design of the study. Important points to be noted are the following. The process and outcome of a onetime physiotherapist's consultation should be tested in a representative group of GPs and physiotherapists, rather than be limited to a highly motivated select group. The process of physiotherapist's consultation needs to be easily incorporated into the daily practice of both GPs and physiotherapists. Furthermore, it is important that the consultation not disturb the day-to-day work situation of GPs and physiotherapists, and fit into the existing, regular modes of cooperation between them.

\section{Introduction}

This paper describes the design of the study, Physiotherapist's Consultation in General Practice: an observational study. In this study, the opportunity of a (one-time) consultation with a physiotherapist is introduced, and subsequently evaluated, as a new element in communication between general practitioners (GPs) and physiotherapists. The outcome measures of the study focus primarily on the opinions of GPs concerning the opportunity 
to refer to physiotherapists for consultation, and the extent to which the physiotherapist's consultations meet the needs and expectations of both the GPs and physiotherapists.

This research is motivated by a number of specific problem areas identified in the cooperation levels between GPs and physiotherapists, ${ }^{1}$ including: poor communication, ${ }^{2-5}$ unclear indications for referral, ${ }^{6-8}$ and lack of clarity about the efficacy of physiotherapy. ${ }^{7-9}$ It is proposed that a GP's patient management policy may be enhanced by referring certain patients for physiotherapist's consultation before deciding whether to refer for treatment. ${ }^{10,11}$ This proposition is supported by the study, Physiotherapy in Primary Care. ${ }^{7}$ That study showed that, on occasion, GPs employ physiotherapist's expertise to diagnose a case or to decide on the indication for physiotherapy. In general, the GPs regarded the opportunity for physiotherapist's consultation as a useful extension of treatment services.

To evaluate the effect of a one-time physiotherapist's consultation, a before-and-after observational study was conducted..$^{12}$ Of great importance in the study's design was the testing of the process and outcome of physiotherapist's consultations in a representative group of GPs and physiotherapists rather than a highly motivated select group. Hence, it was critical that the process of physiotherapist's consultation be easily incorporated into the daily practice of both GPs and physiotherapists, so as not to disturb the day-to-day work situation. Further, the (experimental) possibility of physiotherapist's consultation needed to fit into existing, regular modes of cooperation between GPs and physiotherapists.

In keeping with these requirements, a feasibility study was carried out prior to this present study, in which the feasibility, process of consultation, methods of evaluation, and referral and reporting forms both for GPs and physiotherapists were developed and tested. ${ }^{13.14}$ The physiotherapist's consultation was defined as: "a written request from a GP to a physiotherapist to make an assessment of a particular patient in order to generate information concerning diagnosis and prognosis, with a view to treatment policy to be prescribed by the physician, especially where physiotherapeutic interventions are concerned," From this definition it should be clear that the intention of the physiotherapist's consuitation is not to create a freely accessible consultation hour. The consultation only takes place at the express request of the GP. This confers sole responsibility for the chosen management policy on the GP.

For seven months, a group of GP-physiotherapist pairs participated in the study. Each GP' had the opportunity to consult the physiotherapist (with whom he or she was paired) by referring patients through the use of consultation request and report forms. The objectives of this research were to determine the effects of physiotherapist's consultations in terms of: (1) the quality and efficiency of care provision based on the opinion of consultation outcome: (2) the number of referrals by GPs to physiotherapists and medical specialists when the locomotor system was involved; (3) the utilization of physiotherapy services following a one-time physiotherapist's consultation and (4) the extent to which physiotherapists were able to predict the outcome and volume of care of physiotherapeutic intervention, based on a one-time consultation. 
Table 1. Selected variables expected to be related with referral for physiotherapist's consultation "

\begin{tabular}{|c|c|}
\hline 1. Characteristics of patients & years of establishment \\
\hline Demographic & postgraduate education \\
\hline gender (female) & Perception of physiotherapy \\
\hline age (higher age groups) ${ }^{7,13-17}$ & knowledge about physiotherapy (good) $4, ?$ \\
\hline marital status (single) & cooperation (good)? \\
\hline education (high) ${ }^{\text {is }}$ & diagnostic skills (positive about) ${ }^{17}$ \\
\hline health insurance? ${ }^{7 / 4}$ (NHS) & efficacy of physiotherapy (doubt about) \\
\hline Health status & Referral behavior towand physiotherapy \\
\hline duration of complaints (chronic) ${ }^{13}$ & referral with uncertainty \\
\hline (prior) medical interventions for the same & referral for appropriateness \\
\hline & advice by telephone prior to decision of \\
\hline (type of) disorder ${ }^{3.16 .17}$ in terms of ICPC & referral \\
\hline type and (severity) ${ }^{16}$ of disorder in terms. & III. Characteristics of practices \\
\hline of ICIDH ${ }^{\star}$ & level of urbanization (urban arcas) \\
\hline II. Characteristics of GPs & number of partners (single-handed) ${ }^{\text {is }}$ \\
\hline Demographic & personal list size (larger) ${ }^{14.30}$ \\
\hline age & \\
\hline \multicolumn{2}{|c|}{$\begin{array}{l}\text { Based on a review from Hendriks et al. }{ }^{12} \text { Categories expect. } \\
\text { refernal are shown in parentheses } \\
\text { National Health Insurance Services (NHS) } \\
\text { International Classification of Primary Care (ICPC) })^{21} \\
\text { International Classification of Impairments, Disabilities, an }\end{array}$} \\
\hline
\end{tabular}

\section{Research questions}

Five primary questions provided direction to this research:

1. How do the characteristics of the patient, $G P$ and physiotherapist relate to the number and type of patients referred for physiotherapist's consultation?

Because many factors may contribute to the frequency of physiotherapist's consultation (see Table 1), this question was best addressed by focusing on three key points:

- How often do GPs refer patients for physiotherapist's consultation?

- What characterizes patients who are referred for physiotherapist's consultation?

- To what extent do particular characteristics of the GP, such as work experience, postgraduate education, and the GP's opinion of physiotherapy influence the number of patients referred for physiotherapist's consultation?

\section{How do GPS regard the outcome of the consultation process?}

It is important to assess not only the opinion of the GPs, but also the factors which may contribute to that opinion. Accordingly, this question was best addressed by focusing on two key points:

How do GPs feel about the way their request for consultation was met?

To what extent do patient characteristics (i.e., nature of the complaint/disorder, social and demographic aspects), characteristics of the GP (i.e., perception of cooperation 
and knowledge of physiotherapy), and physiotherapist (i.e., work experience, postgraduate education) affect the GP's opinion on the outcome of the consultation process?

3. What are the GP's courses of action following the physiotherapist's consultations? The focus of this question was, to better understand how the physiotherapist's consultations influenced the GPs' policy of patient care and treatment referral.

This question was best addressed by focusing on four key points:

- What course of action did the physiotherapists recommend?

- To what extent did the GPs act on the recommendations of the physiotherapists?

- After consultation, were the patient treatments prescribed by the GPs different than they would have been prior to consultation?

If the patient treatment policy was changed following consultation, what characteristics of the GP, physiotherapist, or patient, impacted changes in the policy?

4. What effect does the implementation of physiotherapist's consultation have on the number of ireatment referrals to physiotherapists, medical specialists, and other health professions in primary care?

The fourth research question is linked to the third and evaluates the extent to which a shift takes place in the provision of patient care. The question is concerned with both changes from primary to secondary care, and changes in the number of referrals to physiotherapists and other ailied health professions in primary care.

5. What are the characteristics of patients referred for physiotherapy treatment following the consultation and how well has the consulting therapist evaluated the need for therapy based on the one-time consultation?

In understanding the role of the physiotherapist's consultation and the role of treatment, this question focuses on four key points:

- Are there differences in the characteristics of patients who are: referred for physiotherapy treatment following the consultation compared with those who are not so referred?

What is the period of treatment, and how many sessions are recommended to treat patients who, after the physiotherapist's consultation, are referred to physiotherapy?

Additionally, is the duration of the treatment period and the number of treatment sessions following referral by consultation different from the historical treatment records catalogued in the national reference database? ${ }^{23}$

Are patient outcomes related to the consulting physiotherapist's prognosis, and to what extent do characteristics of the patients and physiotherapists influence the duration of treatment period and total number of treatment sessions (see Table 2)?

What is the opinion of the physiotherapist regarding the process of consultation and the opportunity for the GP to refer for consultation? 
Table 2. Patient characteristics expected to be associated with the number of treatment sessions"

\begin{tabular}{lc}
\hline Patient characteristics & \\
\hline 1. Demographic & 1I. Health status \\
age (higher age groups) & duration of complaints (chronic) \\
gender (female) & prior intervention(s) for the same complaints \\
health insurance (NHS)" & type of disorder in terms of ICPC \\
education (low) & functional status in terms of impairments * \\
marital status (single) & functional status in terms of disabilities * \\
\hline
\end{tabular}

\footnotetext{
Variables expected on basis of literature to be associated with a higher number of treatment sessions 30 National Health Insurance Services (NHS)

International Classification of Primary Health Care 21

International Classification of Impairments, Disabilities, and. Handicaps. ${ }^{2}$
}

By addressing these questions, this research can assess: (1) the characteristics of patients referred for a one-time physiotherapist's consultation, (2) the opinion of GPs and physiotherapists on the process and outcome of the consultation, (3) the course of action taken by the GPs following consultation, (4) the effect of a one-time physiotherapist's consultation on the number of treatment referrals to physiotherapy treatment (utilization of physiotherapy services), and (5) the influence of patient characteristics on treatment referral, functional outcome, the duration and number of treatments recommended by the therapist.

\section{Methods}

\section{Design of the study}

Based on the fore-described points of departure, a before-and-after, observational study was carried out. ${ }^{27}$ This study was undertaken with the cooperation of four medical insurance groups in different regions of the Netherlands. ${ }^{\text {note }}$ ! A power analysis ${ }^{28}$ of the chance of referral to physiotherapy for patients with complaints of the locomotor system was carried out based on the feasibility study ${ }^{13}$ and data from the literature. ${ }^{17}$ To detect significant changes in rates of relerral, with an expected chance to be referred by a GP of $16 \%$ and $8 \%$ to a physiotherapist or orthopedist, respectively, and a type I error of 0.05 and a type II error of 0.20 , the minimum estimated number of consultations was 800 . For the purpose of the study, a group of about $60 \mathrm{GP}$-physiotherapist pairs were selected. By means of an a-select random sample, the physiotherapist was selected first. Then, from a list of not more than 5 GPs who usually refer to that physiotherapist, one GP was randomly selected. Figure 1 shows the design of the study. The opportunity to refer for physiotherapist's consultation was made available to participating GPs and physiotherapists for a period of seven months. 


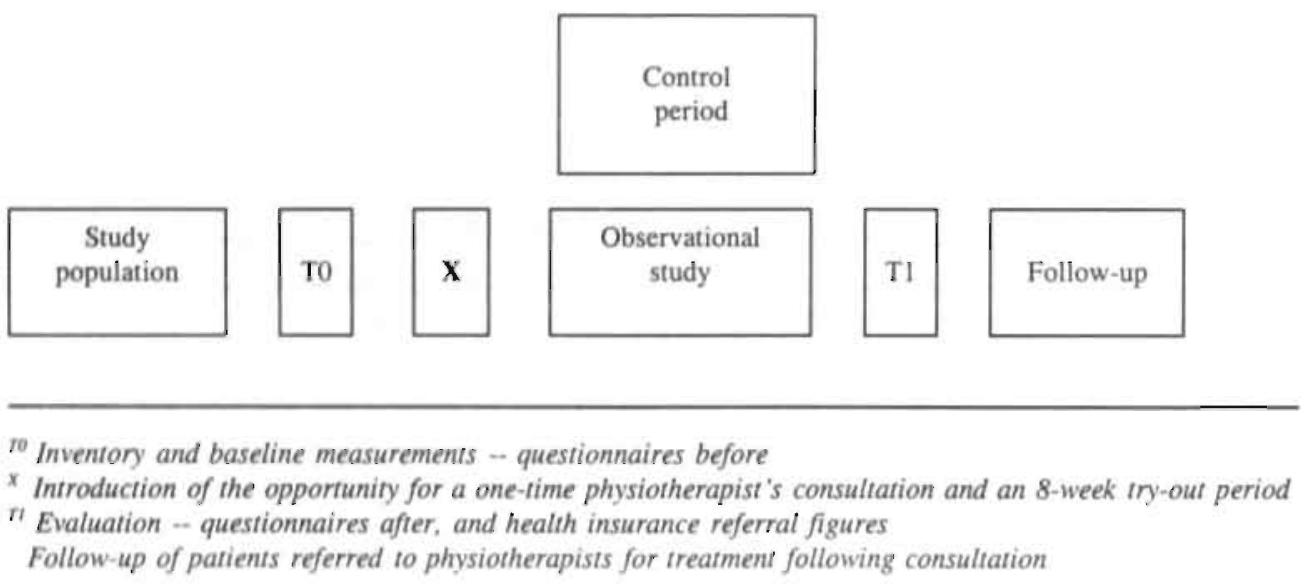

\section{Data collection}

In order to answer the research questions, data were collected using consultation request forms and physiotherapist's report forms. Background information was collected from questionnaires which the GPs and physiotherapists completed at the onset of the study (inventory) and at the completion of the study (evaluation). Data were collected from all referrals to the consultation procedure and from any ensuing physiotherapeutic intervention. In order to answer research question 4 , two types of data were used to gain insight into changes in the pattern of referral and referral figures: (1) a comparison was made between the "fictitious" policy of the GP prior to consultation and the factual GP policy after consultation. The fictitious policy is defined as the policy the GPs reported they might have adopted if the consultation had not been available. The comparison between fictitious and factual policy allowed a more detailed description of changes in the GP's policy; (2) use was made of the data bases from health insurance statistics concerning the number of referrals by GPs to primary and secondary health care provision.

In order to evaluate the effects of a one-time physiotherapist's consultation, a comparison was made between the number of treatment referrals during the seven-month experimental period, and the number of treatment referrals made during the same period of the previous year (control period).

\section{Process of consultation}

In this research, the process of consultation was as follows: The moment the patient visited the GP, the GP and the patient together tried to clarify the patient's complaint and define the problem. These activities resulted in the formulation of a working hypothesis on which the GP based the management policy. In principle. GPs may choose to treat the 
patient themselves, or refer the patient to secondary health care (for treatment or consultation), or refer the patient to another professional in primary health care. At the time of this study, GPs could formally refer patients to physiotherapy only for the purpose of treatment intervention. Hence, the indications for treatment needed to be (formally) clear. ${ }^{29}$ The introduction of physiotherapist's consultation provided the GP with the opportunity to refer the patient to a physiotherapist in order to gain additional diagnostic information and/or to obtain clear information regarding indications for physiotherapy.

In practice, the procedure for a one-time physiotherapist's consultation was proposed as follows: Having decided to refer the patient to physiotherapist's consultation, the GP completed a standard consultation request form. This form included the reason for consultation and the course of treatment the GP planned to prescribe for the patient (Appendix 1). The patient then took the request form to the physiotherapist. The physiotherapist recorded the clinical history, conducted an examination, and analyzed the patient's functional health status in terms of impairments (including location of tissues/organs involved, degree of severity) and disabilities. The physiotherapist recorded the findings on a registration form that contained the patient's personal and sociodemographic characteristics (Appendix 2). Impairments and disabilities were registered on a form specifically designed for that purpose (Appendix 3). The physiotherapist responded to the consultation request within the time limits set by the GP and, using a standard report form, documented the findings and recommendations for patient treatment. If physiotherapy treatment was recommended, the treatment objectives, treatment plan, and prognosis were listed under the heading "physiotherapy indicated." (Appendix 4). The GP assessed the consultation report and, using an enclosed evaluation form (also Appendix 4), documented the influence of the consultation recommendations on the prescribed patient treatment or course of action.

\section{Consultation request and report forms}

Table 3 presents an overview of the consultation request and report forms used in this study. All forms were developed and evaluated during the feasibility study. To develop the consultation forms, a number of criteria were defined. The forms needed to be clear and easy to use in daily practice. The feasibility study showed that GPs did in fact use the opportunity ton physiotherapist's consultation, and that the process and forms proved practicable. The consultation request form was developed in accordance with guidelines set out in a protocol from the Dutch Society of General Practitioners (NHGi). ${ }^{30}$ The objective of the consultation request form (Appendix 1) was to clarify for the physiotherapist the patient's problems, medical history, and present treatment regimen. In addition to medical information, the form allowed the GP to provide relevant psychosocial information about the patient. After completing the consultation request form, the GP was asked to state the reason for the consultation, and to indicate the treatment policy that he or she would have employed had the physiotherapist's consultation not been available (fictitious policy). 
Upon consultation, the physiotherapist registered the patient's personal and sociodemographic data (Appendix 2), and analyzed the patient's functional status in terms of impairments and disabilities (Appendix 3). ${ }^{14,31}$ The physiotherapist's report form. (Appendix 4) was used to document the clinical findings (of a patient's functional status), the consultation conclusions and recommendations, and the prognosis for treatment. This information was then made available to the GP. Following consultation, if the GP decided to refer the patient to physiotherapy treatment, the physiotherapist then stated expected duration of treatment, number of treatment sessions required, and outcome of intervention. For this purpose, a registration form was developed based on the guidelines for documentation of the Royal Dutch Physiotherapy Association (KNGF) ${ }^{32}$ and other descriptive studies into the process of physiotherapy practice. ${ }^{23,33,34}$

To address the research questions and establish the degree to which the study groups represented the general populace of GPs and physiotherapists, background data concerning GPs and physiotherapists was required. Some of the background data, such as age and gender, were readily available from the registration of professions in primary health care. ${ }^{35.36}$ Further data were collected by means of questionnaires designed for the GPs and physiotherapists. ${ }^{12}$ These questionnaires, completed at the onset of the study, consisted of sections containing a number of questions on a certain topic, such as personal status, the organization of the practice, the level of cooperation between GP and physiotherapist, the level of knowledge about the other's professional expertise, personal capacity and attitudes, an estimate of the extent of the practice, and the numbers of physiotherapy referrals by GPs. The personal status data refer to professional training, post-graduate education, and the number of years of experience in primary health care. The section concerned with the organization of the practice refers to, for example, the structure of the practice, the number of working hours, and the extent/size of the practice. The section concerned with cooperation and referral deals with aspects such as the nature of the referrals to physiotherapy, the level and frequency of communication between GPs and physiotherapisis, and the means and frequency of communication in terms of transferring or reporting information. In the latter section, questions were asked concerning knowledge about physiotherapy, and judgment of each other's professional expertise.

The questionnaires employed at the completion of the study were used to evaluate a onetime physiotherapist's consultation, the practicability of the process and the standard forms, any changes in the level of cooperation, and the desirability of a one-time physiotherapist's's consultation in the future. With regard to opinions held on the outcome of consultation, a distinction was made between the GP's opinion regarding the extent to which the request was met, and his or her opinion of the process of consultation by written communication. Overall opinion was traced by means of a questionnaire on the clarity of advice and recommendations given, the extent to which the advice was based on clinical reasoning, and the extent to which clinical reasoning was disputed or lacking. The questionnaire was based on the literature, ${ }^{28}$ and items were selected following the feasibility study. ${ }^{13}$ 
Table 3. The registration forms and data collection

Consultation request form

Registration form

Demographic characteristics

Registration form

Functional status

Report form

Outcome measures

Result of physiotherapy treatment

Questionnuires before the study ${ }^{a}$ Questionnaires after the study"
Appendix I

Consultation report form and arguments for request

Patient data

Fictitious policy in case of no opportunity

to use physiotherapist's consultation

Appendix 2

Non-medical data

Impairments, including severity, location of the complaints and structures affected

Disabilities, including severity

Physiotherapist's advice/recommendations

Treatment options

Appendix 4

Physiotherapist's advice on indication:

if physiotherapy is indicated: treatment goals, management plan and prognosis

Information on the patient's functional status

Number of sessions, and duration of the

treatment episode in weeks

Physiological recovery (impairments)

Functional recovery (disabilities)

Patient's global perceived effect

Background data of GPs and physiotherapists

Evaluation of the study by GPs and

physiotherapists

"For more detailed information on the outcome measures and questionnaires see Hendriks et al ${ }^{n}$

\section{Measurements}

The following measurement procedures were employed to find the answers to each of the study's questions.

1. How do the characteristics of the patient, GP and physiotherapist relate to the number and type of patients referred for a one-time physiotherapist's consultation?

All referrals for consultation were registered by means of the GP's consultation request form and the physiotherapist's report form. Among other things, the patient's sociodemographic characteristics and medical complaints as well as the findings of the physiotherapist were recorded. The International Classification of Primary Care was used for the classification of the medical diagnosis. ${ }^{21}$ Data on the nature of the complaint/disorder, and referral data were collected by means of an open-ended question (e.g., kind of disorder, etc.). These data were retrospectively classified into chapters (letter code), and main headings of the ICPC (number code). Disorders of the locomotor system were classified with the letter code $\mathrm{L}$, and the location of the complaint further specified with a number code; for example, L01 represented disorders of the neck that 
cause locomotor problems. For the registration of a patient's functional status, use was made of the International Classification of Impairments, Disabilities, and Handicaps, ${ }^{22}$ and the Proposal for Adaptation of the ICIDH from the perspective of the allied health professions. ${ }^{37.38}$

This classification allowed an analysis of the functional status of the patient. Also, the physiotherapist formulated a treatment plan, including treatment objectives with respect to impairments and disabilities diagnosed.

Factors that possibly impact the number and characteristics of patients referred to physiotherapist's consultation were determined by means of a questionnaire for GPs. This questionnaire, administered at the onset of the study, was used to obtain data on the GP's work experience and post-graduate education. In addition, the perception of cooperation and communication between GPs and physiotherapists was determined.

\section{How do GPs regard the outcome of the consultation process?}

On a registration form added to the physiotherapist's report, GPs were asked to give an opinion on the extent to which each request for consultation had been met. At the end of the experimental period, by means of a questionnaire, GPs also gave an overall opinion on the outcome of consultation. Opinion about the outcome of consultation referred, for example, to the clarity of the advice, the extent to which the advice was based on clinical reasoning, and the extent to which clinical reasoning was lacking. Factors that possibly influence the process and outcome of consultation were assessed by means of a questionnaire for GPs and a questionnaire for physiotherapists. By means of these questionnaires, data were obtained concerning the physiotherapist's work experience and post-graduate education, and the perception of the quality of cooperation between GPs and physiotherapists.

Data on the nature of disorders and sociodemographic characteristics of patients were obtained from the GP's request forms and the physiotherapist's report forms.

\section{What is the GP's course of action following the physiotherapist's consultation?}

Following consultation, the GP reported his course of action on a registration form affixed to the physiotherapist's consultation report. The answer to question 3 was based on the comparison between the fictitious medical management decision (the course of action which would have been followed had consultation not been available) and the factual management decision. These data were collected by means of the consultation request form.

4. What effect does the implementation of a one-time physiotherapist's consultation have on the number of treatment referrals to physiotherapists, medical specialists and other health professions in primary care?

During the control period and the experimental period, health insurance data were referenced on the number of referrals made to physiotherapy, to other health professionals 
(exercise therapists, Cesar and Mensendiek method therapists, and podotherapists [podiatry]), and to medical specialists. The medical specialists considered most relevant for the purpose of this study were: orthopedists, neurologists, rheumatologists, and physiatrists (rehabilitation physicians).

5. What are the characteristics of patients referred for physiotherapy treatment following the consultation, and how well has the consulting therapist evaluated the need for therapy based on a one-time consultation?

Differences in characteristics between patients who were referred to physiotherapy treatment and those not referred for treatment were registered using the forms described in the first question. If the GP decided to refer a patient to physiotherapy treatment, the physiotherapist registered the number of sessions, the length of the treatment period, and the course of treatment. Additionally, a prognosis of the outcome of physiotherapy and an estimate of the duration of physiotherapy and number of treatments was required.

\section{Selection of the subjects}

Based on the results of the feasibility study, ${ }^{13}$ a group of about 60 GP-physiotherapist pairs were required for this study. Three considerations played an important part in compiling a random sample of physiotherapists and GPs. ${ }^{12}$ First, the availability of physiotherapist's consultation needed to be evaluated in representative groups of GPs and physiotherapists. Second, it was important that the physiotherapists and GPs selected had a close working relationship. Third, on logistical grounds, it was important that a number of GPphysiotherapist pairs worked in the same district.

It was expected that the physiotherapist would have to invest considerable time in each referral for consultation. ${ }^{11.12}$ Hence, the physiotherapist was selected first, and the GP was selected through the physiotherapist. For each physiotherapist, one GP was selected. The design of the study allowed the GP to refer for consultation only to one of the physiotherapists usually referred to for treatment. An a-select random sample was required in order to generalize the results of the study. Variables that are potentially explanatory such as practice characteristics (degree of urbanization, organization of the practice), ${ }^{76.19 .39,40} \mathrm{GP}$ and physiotherapist characteristics, and patient characteristics ${ }^{7.16,17}$ were therefore represented in the random sample. On pragmatic grounds, the level of urbanization was chosen for stratification. In a random sample of this size, there was a chance that the different categories of urbanization might not reflect the total population. Stratification allowed a random to be drawn that was equally distributed among GP and physiotherapist practices according to the degree of urbanization. Hence, an a-select, nonproportional random sample, stratified by degree of urbanization, was chosen. 
Table 4. Number of general practitioners (GPs) and physiotherapists (PTs) working in primary health care stratified by level of urbanization "

\begin{tabular}{lcccc}
\hline $\begin{array}{l}\text { Grouping of GPs and PTs by } \\
\text { category of urbanization }\end{array}$ & \multicolumn{2}{l}{$\begin{array}{l}\text { Total number of GPs in the } \\
\text { Netherlands }\end{array}$} & Total number of PTs in the \\
& N & $\%$ & Netherlands & $\%$ \\
\hline Rural areas & 1963 & 30.0 & 2647 & 26.0 \\
Semi-urbanized areas & 2283 & 34.8 & 3595 & 35.3 \\
Urban areas & 2302 & 35.2 & 3945 & 38.7 \\
Total & 6548 & 100.0 & 10187 & 100.0 \\
\hline
\end{tabular}

- Nivelregister ${ }^{13.16}$

\section{Stratification}

The levels of urbanization were admitted as variables of stratification in the draw of the random sample. Based on the CBS-classification, ${ }^{41,42} 3$ groups were distinguished:

- Group 1 = rural: Comprises CBS-categories A1, A2, A3, A4, B1, C1, and C2: country towns, small semi-urban country towns, and small towns (up to 30,000 inhabitants).

- Group 2 = semi-urban: Comprises CBS-categories B2, B3, and C3: larger urban country towns, dormitory suburbs, and larger towns (up to 50,000 inhabitants).

- Group 3 = urban: Comprises CBS-categories C4, and C5: cities with more than 50,000 inhabitants.

Table 4 shows the number and percentage of GPs and physiotherapists working in The Netherlands in each category of urbanization. In addition, possibly significant variables were not considered for stratification because, in drawing a random sample of this size, too large a stratification results in too few subjects per cohort. In each health insurance district $(n=4)$, an equal number of GPs and physiotherapists were selected and stratified for degree of urbanization $(\mathrm{n}=15)$. This means that $4 \times 3=12$ cohorts were formed.

\section{Target population and population sampled}

The point of departure in drawing the random sample was the Register of Physiotherapists per 1 January 1992 , based on the Nivel registration. ${ }^{35}$ The register includes almost all physiotherapists working in primary health care and provides a registration number, the council code, the degree of urbanization, and the address of the physiotherapist practice. The a-select random sample of physiotherapists was drawn from the register of all practicing physiotherapists in possession of a contract with at least one of the four participating health insurance companies. Further, in the areas of participating GPs, it was important that the number of patients registered with the participating insurance company and/or overlapping insurance companies should be more than $90 \%$. These conditions were set out to avoid the chance of not being able to register the course of action and number of interventions in the case of health insurance patients who were referred. The resulting random sample comprised 1533 physiotherapists. 
In anticipation of negative responses, we decided to draw a random sample (with no restoration) of double the necessary size, the sample thus totaling 120 physiotherapists. In this way, a reserve list was compiled and matched for category of urbanization and health insurance district. This reserve list was available in case a physiotherapist, when first approached, refused to take part in the study. By drawing the random sample without the option of restoration to the register, the chance of a physiotherapist being drawn more than once was avoided. The physiotherapists were grouped into 12 random sample cohorts by a computer program.

The physiotherapists selected were asked to participate in the study by means of a canvassing letter and some background information which, together with a letter of recommendation from the Royal Dutch Association of Physiotherapists (KNGF), was mailed to them. At the same time, an article about the research into the effects of a onetime physiotherapist's consultation on primary health care was published in the Dutch Journal of Physiotherapy. "The purpose, design, and methods of the study were explained in this article, combined with positive editorial comment. Additionally, the appropriate Regional Associations of Independent Physiotherapists (RVVF) were informed about the project and promised to support the study, Physiotherapist's Consultation in General Practice. When a physiotherapist agreed to participate in the study, a GP was selected from a list of, at most, five GPs who refer to the physiotherapist's practice. The selected GP was informed both by telephone and by a canvassing letter supported by a letter of recommendation from the Dutch Society of General Practitioners (NHG). The appropriate District Society of General Practitioners was informed of the study, and asked to support it, which they did. If the selected GP refused to participate, the same procedure was used to select an alternative GP, who was then asked to participate in the study.

The participating GPs and physiotherapists were given instructions both in person and in writing (by means of a manual) about the procedure of physiotherapist's consultation and about the way in which registration forms should be completed. The process of consultation and the method of registration were tested during a practice (try-out) period of eight weeks prior to the start of the research. Furthermore, three instructional evenings were held for the physiotherapists, during which problems could be discussed.

To obtain an impression of how well the random sample represented the general populace, data were compared with the register of professions for physiotherapist and GPs working in primary health care. ${ }^{35.36}$

\section{Data management and analysis}

Data from the registration forms were input with the assistance of a specially ceveloped code-book and Data Entry (SPSS-PC + , version 4.01). With a view to compatibility of data, the patients' complaints were coded using the same determinants as those used in the national reference data. ${ }^{23}$ In the code-book, the range of measurement, the unit, and the: significance of the code were defined for each variable. Data from patients and participants were rendered anonymous. 
Table 5. Distribution of the number of GP-physiotherapist pairs within each category of urbanization

\begin{tabular}{llc}
\hline Categories of urbanization & \multicolumn{2}{c}{ GP-PT pairs } \\
\cline { 2 - 3 } & $\mathrm{n}$ & $\%$ \\
\hline Rural areas & 19 & 32.2 \\
Semi-urbanized areas & 23 & 39.0 \\
Urban areas & 17 & 28.8 \\
Total & 59 & 100.0 \\
\hline
\end{tabular}

Prior to the analysis, the data were cleansed, and subsequently, each separate case was checked for completeness (the complete data of a patient referred to physiotherapist's consultation per pair) by means of straight counts, frequency tables, and distribution of frequency. If a case record turned out to be incomplete, an attempt was made within one month to recover the missing data, and a subsequent check was made to determine the importance of the missing data. For each research question, selected variables were described and were used in further analyses. The results of the study, Physiotherapist's Consultation in General Practice, were displayed in terms of descriptive statistics. For the explanatory segment, use was made of bivariate and multivariate techniques of analysis. The analysis of each research question consists of an examination of the bivariate and multivariate relationships between predictor variables and the criterion variables. In the initial analysis, the bivariate relationships between criterion and predictor variables were examined. Those variables significantly related with the criterion variables were retained for further multivariate analyses. Multivariate procedures were used subsequently. For each question, the criterion variable and the predictor variables used were explained and described more closely. Data were analyzed with the aid of SPSS for Windows (version 4.01) or ML3 (software package for multi-level modeling). ${ }^{43}$ As the data are characterized by a hierarchical order, in which patients (lower level) are nested within GPphysiotherapist pairs (higher level), use was made of hierarchical multi-level analysis (MLA) ${ }^{43-40}$ Depending on the testing level of the variable, statistical methods included chi-square test or, for categorical data when appropriate, student's t-test for comparison of means for paired observations variables(possibly the non-parametric Wilcoxon's signed rank and/or rank sum tests). ${ }^{47}$ This provided an impression of: the participant representation; the differences between patients referred for physiotherapist's consultation and those of the national reference data of patients referred for physiotherapy treatment; the changes in the (before-and-after comparison) course of action taken by the GP. The level of statistical significance was set at $\mathrm{p} \leq 0.05$ for all tests.

\section{Participant representation}

As indicated in the methods section, a group of approximately 60 GP-physiotherapist pairs was required. Physiotherapists were approached first by means of an a-select, nonproportional, stratified random sample. Then, through the chosen physiotherapist, the GP was selected. The random sample population, from which the a-select random sample of 
physiotherapists was drawn, comprised 1533 physiotherapists. Of the total a-select random sample of 75 physiotherapists (25 physiotherapists were approached per stratum), 62 physiotherapists agreed. to take part in the study (percentage of participants $=82 \%$ ). The physiotherapist was asked to list a maximum of five GPs who referred to their practice for treatment. Based on this list, a GP was randomly selected to participate in this study $(n=62)$. If a GP chose not to participate, the same procedure was used to select another GP $(n=+22)$. In total, 84 GPs were invited to participate, with $74 \%$ of those invited actually participating in the study.

Of the 62 GP-physiotherapist pairs participating in this study, three GPs withdrew within the first month of the study. The three GPs withdrew due to respectively: a reorganization of their practice, a move to another practice, and problems within the partnership. Of these three GPs, one belonged in the rural category, and two in the urban category. At the conclusion of the study, data were collected from the $59 \mathrm{GP}$. physiotherapist pairs who participated throughout the duration of the study. Table 5 shows the distribution of teams within each category of urbanization.

\section{Physiotherapist characteristics}

Gender and age distribution were compared with corresponding data from the national register of professions. ${ }^{35}$ More male than female physiotherapists participated in the study $(62.7 \%$ versus $37.3 \%)$. This does not differ significantly from the national gender ratio for physiotherapists working in primary health care $(52.2 \%$ versus $47.8 \%)$. The average age of the participating physiotherapists was 36.7 years $(s d=6.1)$. The largest group of physiotherapists was in the age category $25-45$ years. When the age distribution was compared with national distribution, it appeared to represent the profession, with the exception of the "younger than 25 years" age categories. Table 6 shows that the majority of the physiotherapists had wide working experience in terms of years of establishment (35/59 [59\%] longer than 10 years), and a small number graduated recently (4/59 [7\%] under 5 years).

Compared with national data, this indicates a significant under-representation of physiotherapists with work experience of less than 5 years, and an over-representation of physiotherapists with work experience of more than 5 years. The distribution of the participating practices showed a strong over-representation of group practices and a strong under-representation of single-handed practices $(p<0.05)$.

The participating physiotherapists spent, on average, 37 hours on direct patient care $(s d=9.7)$. Compared with national data, the physiotherapists participating in the study had less part-time work. Practically all participants appeared to have taken at least one refresher or follow-up course. ${ }^{48}$

The predominant number of post-graduate courses was three for each physiotherapist. This was in agreement with the findings of an exploratory study into the magnitude of the number of refresher and follow-up courses taken by physiotherapists. The number of physiotherapists with the approved specialty "manual therapy" agrees with national data. 
Physiotherapists with a sports physiotherapy specialty were over-represented $(p<0.05)$. Other types of approved specialties and other post-graduate education were not specified further.

\section{Characteristics of general practitioners}

Table 7 compares the GPs' gender and distribution by age with corresponding data from the register of professions. ${ }^{36}$ Fifty-five male and 4 female GPs participated in the study. This distribution does not differ significantly from national distribution. The average age of the participating GPs was 43.5 years $(s d=7.0$ ), and varied from 29 to 60 years. More than half the participating GPs were younger than 45 , which is consistent with the Dutch population of GPs.

A small number of GPs had only recently completed their professional training, and $59 \%$ had more than 10 years' experience in primary health care. Nearly half the GPs worked single-handed. Table 6 shows that the distribution of GPs according to structure of practice agrees with the Dutch population of GPs. It should be noted that the reference data on the Dutch population of GPs working in health centers $(8.6 \%)$ are not discriminated..$^{36}$ The list size of the GP practices varied from 250 to 4500 patients. The majority of the GPs ( $80 \%$ ) had a list size of 2000 to 3150 patients (the average list in this study is 2516 registered patients [practice norm is 2350 patients]). ${ }^{36}$

\section{Comment}

This paper describes the design of the study, Physiotherapist's Consultation in General Practice: an observational study. The study deals in particular with the opinions of GPs concerning the opportunity to refer to physiotherapists for a one-time consultation, and with the extent to which physiotherapist's consultation meets the needs and expectations of GPs and physiotherapists. ${ }^{49,50}$

Consultation is not a new concept in Dutch health care. However, consultation by GPs with various primary health care disciplines rarely occurs. ${ }^{11.51} \mathrm{~A}$ search of the literature showed that no studies have been published on the possible effects of implementing a onetime physiotherapist's consultation in primary health care. ${ }^{51}$ It was expected that the physiotherapist's consultation would contribute to the efficiency of physiotherapy care, ${ }^{7.11,51.52}$ since the consultation might help clarify the need or indication for physiotherapy. If a GP had some uncertainty or expressed a lack of clarity concerning a policy for physiotherapeutic care, the process of consultation by a physiotherapist provided an additional referral tool for the GP. Should the GP decide, after consultation, to refer the patient for physiotherapy treatment, treatment objectives and strategy would have been explicitly formulated and written down by the physiotherapist. However, an initial lack of clarity about the indication for physiotherapy could result in inappropriate physiotherapeutic care. ${ }^{53}$ 
Table 6. Years post-graduation, years of experience in primary health care, number of partners, hours spent on direct patient care, and the amount of refresher-and follow-up courses for the participating physiotherapists (PTs) compared with the Dutch body of PTs working in primary health care"

\begin{tabular}{|c|c|c|c|}
\hline & \multicolumn{2}{|c|}{ Characteristics of the PTs } & \multirow{2}{*}{$\begin{array}{c}\text { Netherlands } \\
\%\end{array}$} \\
\hline & $\mathbf{n}$ & $\%$ & \\
\hline \multicolumn{4}{|c|}{ Years post-graduate } \\
\hline $0-4$ & 3 & 5.1 & 13.5 \\
\hline $5-9$ & 15 & 25.4 & 24.5 \\
\hline $10-14$ & 17 & 28.8 & 26.3 \\
\hline $15-19$ & 18 & 30.5 & 17.9 \\
\hline$>20$ & 6 & 10.2 & 17.8 \\
\hline Total & 59 & 100.0 & 100.0 \\
\hline \multicolumn{4}{|c|}{ Years of experience ${ }^{*}$} \\
\hline $0-4$ & 4 & 6.8 & 34.4 \\
\hline 5-9 & 20 & 33.8 & 23.6 \\
\hline$>10$ & 35 & 59.4 & 40.0 \\
\hline Total & 59 & 100.0 & 100.0 \\
\hline \multicolumn{4}{|c|}{ Number of partners ${ }^{\circ}$} \\
\hline single-handed & 5 & 8.5 & 34.9 \\
\hline 1 partner & 7 & 11.9 & 21.2 \\
\hline$>1$ parmer & 45 & 76.2 & 43.9 \\
\hline health center" & 2 & 3.4 & \\
\hline Total & 59 & 100.0 & 100.0 \\
\hline \multicolumn{4}{|c|}{ Number of hours a week } \\
\hline $0-8$ & - & & 2.9 \\
\hline $9-16$ & 2 & 3.4 & 11.3 \\
\hline $17-24$ & $s$ & 8.5 & 15.7 \\
\hline $25-32$ & 14 & 23.7 & 15.9 \\
\hline $33-40$ & 19 & 32.2 & 34.5 \\
\hline$>40$ & 19 & 32.2 & 19.2 \\
\hline Total & 59 & 100.0 & 100.0 \\
\hline \multicolumn{4}{|c|}{$\begin{array}{l}\text { Number of refresher-and follow- } \\
\text { up courses }\end{array}$} \\
\hline 0 & 4 & 6.8 & 4.9 \\
\hline $1-2$ & 17 & 28.8 & 29.2 \\
\hline $3-4$ & 20 & 33.9 & 35.0 \\
\hline$>5$ & 18 & 30.5 & 30.9 \\
\hline Total & 59 & 100.0 & 100.0 \\
\hline
\end{tabular}

" Figures from the register of professions in primary health care 15

- 469 PTs work in 124 healih centes ${ }^{15}$

' Refresher and follow-up courses taken by PTs working in primary health care ${ }^{\text {s }}$

* p<0.05 (chi $\left.{ }^{2}\right)$ 
Accordingly, in order to gain insight into the efficiency of treatment, checks will be made on treatment outcomes (from the perspective of the physiotherapist). The number of sessions and the extent of the treatment will be documented. This data will be compared with national reference data on physiotherapeutic treatment. ${ }^{23}$ To evaluate the effect of a one-time physiotherapist's consultation, the fore-described, quasi-experimental study was conducted. In designing the study, a true-experimental rather than quasi-experimental design was considered. From a methodo-logical perspective, a true-experimental design was preferable. However, this was decided against on the following grounds. In a trueexperimental set-up, a relatively large number of GPs would have been required to participate both in the experimental and in the control group since large variations exist among GPs in the number of patients they refer to medical specialists or physiotherapists. ${ }^{7.17,40,54}$ A possible shift in referral figures resulting from the physiotherapist's consultation would only have become apparent if a large number of GPs had been involved in the study. A power analysis showed that in a design using two groups of GPs, in order to make apparent the effect of the number of referrals to physiotherapists, the number of GPs in the study needed to be almost four times as large as in the design finally decided upon. ${ }^{12}$ So, a study involving two separate groups would have been highly extensive and costly.

To facilitate the research into the effects of physiotherapist's consultation on the number of referrals by GPs to physiotherapists and medical specialists, registering all GP contacts during the field trial would have been desirable. However, the registration of such a volume of data would have had an adverse effect on the GPs' willingness to participate in the study. For this reason, health insurance figures, among others, were employed, despite their limitation with regard to generalization. ${ }^{55.56}$ Nevertheless, a choice was made to use health insurance figures in order to place the least possible burden on GPs. The number of referrals made by GPs to medical specialists (orthopaedics, rheumatology, neurology, and rehabilitation medicine) and physiotherapists were compared during the experimental, and control, period. Analyzing referral figures to all specialists is unnecessary and would have caused a superfluous augmentation of the research. However, the most important argument against admitting data on referrals to other, less relevant medical specialists, is that to do so would obscure any differences in the number of target referrals made during the experimental and control periods.

One problem with the quasi-experimental design of this study is that a shift-trend in the number of referrals might be unjustly ascribed to the introduction of physiotherapist's's consultation. It was, in part, possible to anticipate this problem by investigating the context of changes in referrals. Whether the factual use of physiotherapist's consultation was related to changes in referrals to primary or secondary care has been considered. If, for instance, the number of referrals to physiotherapy are related to a reduction in the number of referrals to secondary care, this may indicate that physiotherapist's consultation leads to a reduction in the number of referrals to secondary care. The response to the request to participate was high for both professional groups (GPs $74 \%$; physiotherapists $82 \%)$. 
Table 7. Personal and practice characteristics of participating genenal practitioners (GPs), compared with the Dutch population of GPs"

\begin{tabular}{|c|c|c|c|}
\hline & \multicolumn{2}{|c|}{ Characteristics of the GPs } & \multirow{2}{*}{$\begin{array}{c}\text { Netherlands } \\
\%\end{array}$} \\
\hline & $\mathrm{n}$ & $\%$ & \\
\hline \multicolumn{4}{|l|}{ Gender } \\
\hline male & 56 & 94.9 & 86.8 \\
\hline female & 3 & 5.1 & 13.2 \\
\hline Total & 59 & 100.0 & 100.0 \\
\hline \multicolumn{4}{|c|}{ Distribution by age } \\
\hline$<34$ & 3 & 5.0 & 10.0 \\
\hline $34-44$ & 31 & 52.5 & 54.1 \\
\hline $45-54$ & 19 & 32.3 & 22.7 \\
\hline $55-64$ & 6 & 10.2 & 12.4 \\
\hline$>65$ & - & - & 0.9 \\
\hline Total & 59 & 100.0 & 100.0 \\
\hline \multicolumn{4}{|c|}{ Years of experience } \\
\hline $1-2$ & 1 & 1.7 & - \\
\hline $3-4$ & 5 & 8.5 & $\bullet$ \\
\hline $5-7$ & 7 & 11.9 & $\bullet$ \\
\hline $8 \cdot 10$ & 11 & 18.6 & - \\
\hline$>10$ & 35 & 59.3 & $\bullet$ \\
\hline Total & 59 & 100.0 & $\bullet$ \\
\hline \multicolumn{4}{|c|}{ Number of partners } \\
\hline single-handed & 28 & 47.5 & 53.6 \\
\hline 1 partner & 19 & 32.2 & 30.5 \\
\hline$>1$ partner & 9 & 15.3 & 15.6 \\
\hline health centre ${ }^{b}$ & 3 & 5.1 & $\bullet$ \\
\hline Total & 59 & 100.0 & 100.0 \\
\hline \multicolumn{4}{|l|}{ Personal list size } \\
\hline$<2000$ & 7 & 10.2 & $\bullet$ \\
\hline $2000-2350$ & 13 & 22.0 & - \\
\hline $2351-2700$ & 21 & 35.6 & - \\
\hline $2701-3050$ & 13 & 22.0 & - \\
\hline$>3050$ & 5 & 10.2 & $\bullet$ \\
\hline Total & 59 & 100.0 & $\bullet$ \\
\hline
\end{tabular}

- Figures of the register of professions in primary health care ${ }^{\text {to }}$

- From 1990 onwards, health centers are no longer listed separasely 16

* $p<0.05\left(\mathrm{Chi}^{2}\right)$

- Dara nor available

The description of the personal, and practice, characteristics of the GPs shows that they are, in fact, representative of the professional body. It should be noted that the two-step random selection meant that few GPs were selected who rarely refer to physiotherapy. The description of the physiotherapists shows that some selection occurred with regard to the number of years' experience in primary health care. One finding shows that 
physiotherapists with relatively little experience in primary health care more frequently passed up the request to participate in the study. The physiotherapists selected had more experience in primary health care, and physiotherapists working in group practices were over-represented. The physiotherapists were found to be representative in terms of their personal characteristics of age and gender, the number of post-graduate years in practice, and the extent to which refresher- and follow-up courses had been taken. In the interpretation of the results, it should be borne in mind that, compared with the national data, the physiotherapists in the study have a greater than average experience of working in primary care.

In summary, the present study was designed to: (I) investigate the frequency of use of physiotherapist's consultation by GPs when the opportunity for consultation was provided to them; and (2) the extent to which the consultation requests met the needs and expectations of both the GPs and physiotherapists. Consequently, the study focussed mainly on the pragmatic procedures to prevent unnecessary referrals, to improve the efficiency of care, the quality of patient communication, and GPs' knowledge about physiotherapy practice. Furthermore, this study provides important information concerning the preconditions for successful implementation of physiotherapist's consultation in general practice.

\section{References}

1. Ministerie van Welzijn Volksgezondheid en Cultuur (WVC). Notitie Ontwikkeling Fysiotherapeutische Hulpveriening. Rijswijk, 1989.

2. Rijdt van der T, Lubbers $M$, Kolker $L$. Het verbeteren, van samenwerking. Eindverslag van het project Samenwerking huisarts en fysiotherapeut. Utrecht: Stichting O\&O, 1990.

3. Hulme JB, Wackernagel: B, Lewis JW. Communication between physicians and physical therapists. Physical Therapy 1988;68:26-31.

4. Stanton PE, Fox FK, Francois KM, Hoover DH, Spilecki GM. Assessment of resident physicians' knowledge of physical therapy. Physical Therapy 1985;65:27-30.

5. Uiili RM, Shepard K, Savinar E. Physician knowledge and utilization of physical therapy procedures. Physical Therapy 1984:64:1623-1530.

6. Anderson J, Campbell SK. Correlates of physician utilization of physical therapy. International Journal of Technology Assessment in Health Care 1992:8(1):10-19.

7. Kerssens J], Curfs EChr. Extramurale fysiotherapie. Utreçht: Nivel, 1993 (Dissertatie Rijksuniversiteit Utrecht).

8. Ritchey FJ, Pinkston D, Goldbaum JE, Heerten ME. Perceptual correlates of physician referral to physical therapisst: Implications for role expansion. Social Science \& Medicine 1989:28: 69-80.

9. Beckerman H, Bouter LM, Heijden GJMG van der, Bie RA de, Koes BW. Efficacy of physiotherapy for musculoskeletal disorders: what can we learn from research? B J Gen Pract. 1993:43:73-77.

10. Kerssens JJ, Groenewegen PP. Referrals to physiotherapy: the relation between the number of referrals, the indication for referral and the invlination to refer. Social Science \& Medicine 1970;30(7):797-804.

11. Hendriks HJM, Wagner C. Brandsma JW, Dekker J, Wams HWA, Oostendorp RAB. Consultatief Fysiotherapeutisch Onderzoek (CFO) in de eerste lijn. Introduktie van het CFO-project en informatie uit de literatuur. Ned Tijdschr Fysiother. 1992:102:176-183. 
12. Hendriks HJM, Wagner C, Dekker J, Brandsma JW. Evaluatic van het consultatief fysiotherapeutisch onderzoek in de eerste lijn. Resultaten van een veldexperiment. Utrecht: Nivel, 1994

13. Hendriks HJM, Wagner C, Brandsma JW, Oostendorp RAB, Dekker J. Experiences with physiotherapsist consultation. Results of a feasibility study. Physiotherapy Theory and Practice 1996:12(4):211-220.

14. Hendriks HJM, Brandsma JW, Heerkens YF, Oostendorp RAB, Nelson RN. Intra-observer and interobserver reliability of assessments of impairments and disablities. Physical Therapy 1997;77:1097. 1106.

15. Akpala CO, Curran AP, Simpson J. Physiotherapy in general practice: pattems of utilization. Public Health 1988:102:263-268.

16. Uunk WJG, Groenewegen PP, Dekker J. Verwijzingen van huisartsen naar fysio-therapeuten: een verklaring en analyse van verschillen tussen huisartsen. Mens en Maatschappij 1992;67(4):389-411.

17. Uunk W, Dekker J, Groenewegen P. Verwijzingen van huisartsen naar fysiotherapeuten: morbiditeitsspecifieke verwijspercentages. Deelproject Huisarts en fysiotherapeutische zorg: Basisgegevens uit de Nationale Studie van Ziekten en Verrichtingen in de Huisartsenpraktijk. Utrecht: Nivel, 1991.

18. Moncur C. Perceptions of physical therapy competencies in rheumatology. Physical therapists versus rheumatologists. Physical Therapy 1987;67(3):331-339.

19. Wijkel D. Lower referral rates for integrated health centres in The Netherlands. Health Policy 1986;6:185. 198.

20. Posthuma BH, Zee J van der. Verwijscijfers en de verkleining van de huisartspraktijk. Gezondheid en Samenleving 1980;1:59-68.

21. Lamberts H, Wood M. International Classification of Primary Care. Oxford: Oxford University Press, 1987.

22. Worid Health Organization. ICIDH, International Classification of Impairments, Disabilities, and Handicaps: a manual of classification relating to the consequences of disease. Geneva: WHO, 1980.

23. Valk R van der, Dekker J, Boschman M. Basisgegevens extramurale fysiotherapie 1989-1992. Gegevens uit het project Beleidsgericht Evaluatie- en Effectonderzoek Fysiotherapie (BEEF). Utrecht: Nivel, 1995.

24. Zuiderduin W, Dekker J, Abrahamse H. Determinanten van de omvang van de behandeling in de extramurale fysiotherapie. Tijdschr Soc Gezondheidsz. 1995;73(5):274-281.

25. Mischner CD, Klaveren AAJ, Wams HWA, Elvers JWH, Oostendorp RAB, Hendriks HJM. Variabelen in samenhang met aantal behandelingen fysiotherapie. Amersfoort: NPi, 1995.

26. Roebroeck ME, Hutten JBF, Kerssens JJ, Dekker J. De omvang van de fysio-therapeutische behandeling naar verschillende patiënıcategorieën. Utrecht: Nivel, 1995.

27. Cook TD, Campbell DT. Quasi-experimentation. Design and analysis issues for field settings. Boston: Houghton Mufflin Compny, 1979.

28. Cohen J. Statistical power analysis for the behavioral sciences. Hillsdale: Lawrence Erlbaum Associates, 1988.

29. Fysiotherapeutenbesluit. In: Staatsblad van het Koninkrijk der Nederlanden, 1977 no.432: Besiuit van 1 juli 1977 tot vaststelling van nieuwe regelen inzake het beroep van fysiotherapeut.

30. Nederlands Huisartsen Genootschap (NHG). De verwijsbrief naar de Tweede Lijn - standaard 001 . Huisarts Wet. 1898;32:102-105.

31. Triet EF van, Dekker J, Kerssens JJ, Curfs EChr. Reliability of the assessment of impairments and disabilities in survey research in the field of physical therapy. Int Disabil Stud. 1990;12(2):61-65.

32. Koninklijk Nederlands Genootschap voor Fysiotherapie (KNGF). Richılijnen voor de fysiotherapeutische verslaglegging. Amersfoort: KNGF, 1993.

33. Leemrijse C, Mischner-van Ravensberg CD, Oostendorp RAB. Een brede inventarisatie van het fysiotherapeutisch zorgverleningsproces in de eerstelijnsgezondheidszorg. Ned Tijdschr Fysiother. 1992: 102:208-2!8.

34. Klaveren van AAJ, Hendriks HJM, Oostendorp RAB. Ravenberg, van CD, Elvers JWH. Basisgegevens van het Fysiotherapie Ontwikkelings Netwerk. Een inventarisatie van het fysiotherapeutisch handelen in de eerste lijn m.b.v. het Basis Registratieformulier Fysiotherapie. Amersfoor: NPi (SWSF), 1996. 
35. Pool JB, Hingstman L. Cijfers uit de registratie van beroepen in de eerstelijnsgezondheidszorg 1991. Statistische gegevens per 1 januari 1991 over in de eerste lijn werkzame fysiotherapeuten Utrecht: Nivel, 1993.

36. Pool JB, Hingstman L. Cijfers uit de registratie van beroepen in de eerstelijnsgezondheidszorg. Statistische gegevens per 1 januari 1991 over huisartsen en verloskundigen. Utrecht: Nivel, 1992.

37. Heerkens YF, Brandsma JW, Ravensberg CD, Proposal for adaptation of the International Classification of Impairments, Disabilities, and Handicaps from the perspective of five Dutch health professions. Zoetermeer, Dutch Classification and Terminology Committee for Health (WCC) - National Council for Public Health (NRV), 1993.

38. Heerkens YF, Brandsma JW, Lakerveld-Heyl K, Ravensberg van CD. Impairments and disabilities - The difference. Proposal for adjustment of the international classification of impairments, disabilities, and handicaps. Physical Therapy, 1994:74:430-442.

39. Foets $\mathbf{M}$, Velden $\mathbf{J}$ van der. Nationale studie naar ziekten en verrichtingen in de huisartsenpraktijk. Basisrapport: Meetinstrumenten en procedures. Utrecht: Nivel, [990.

40. Wilkin D, Smith A. Explaining variation in general practitioners referrals to hospital. Fam Prac. 1987;4:160-169.

41. Centraal Bureau voor de Statistiek. Vademecum Gezondheidsstatistiek. 's. Gravenhage: CBS, 1992.

42. Centraal Bureau voor de. Statistiek. Statistisch zakboek. 's Gravenhage: CBS, 1991 .

43. Prosser R, Rasbash J, Goldstein H. ML\# Software for three-level analysis. User's guide for V.2. London: University of London, Institute of education, 1991.

44. Rasbach J, Woodhouse G. MLA Command reference. London: Institute of Education, University of London, 1995.

45. Bryk AS, Raudenbusch SW. Hierarchical Linear Models: applications and data management methods. Newbury Park: Sage publications, 1992.

46. Goldstein H. Multilevel statistical models. New York: Halsted Press (2 ${ }^{\text {nt }}$ edition), 1995.

47. Armitage P. Berry G. Statistical methods in medical research (2nd ed). Oxford: Blackwall Scientific Publications, 1987.

48. Brink-Muinen A. Dekker J. Na-en bijscholing van fysiotherapeuten in de eerste lijn. Een onderzoek naar het aanbod van zorg. Utrecht: Nivel, 1991.

49. Nationale Raad voor de Volksgezondheid (NRV), Discussienota 'Algemeen begrippen-kader kwaliteitsbevordering'. Zoetermeer, 1990.

50. Sluijs EM, Bakker DH de, Dronkers J. Kwaliteitssystemen in uitvoering. Utrecht: Nivel, 1994.

51. Hendriks HJM, Zee van der J, Bie de RA. Consultation between general practitioners and medical consultants in the Dutch Health care system. What can we learn from research? (submitted)

52. Bertels M, Brummeler L ten, Dijkum C van, Giebels R, Mannen J van der. Tijd voor kwaliteit: evaluatieonderzoek fysiotherapic in gezondheidscentra in Amsterdam. Amsterdam: SISWO, 1985.

53. Groenewegen PP. Hingstman L, Dekker J. Gebruik en beschikbaarheid van fysiotherapeutische zorg in de toekomst. Ned Tijdschr Fysiother. 1990;100:84-91.

54. Evans A. A study of the referral decision in general practice. Fam Prac. 1993:10(2):104-110.

55. Stokx L, Gloerich ABM, Kersten TJJMT. Kostenbesparing door kwaliteitsbevordering. Utrecht: Nivel, 1992.

56. Stokx LJ, Bakker DH de, Delnoy DMJ, Gloerich ABM, Groenewegen PP. Verwijscijfers belicht. Utrecht: Nivel, 1992.

\section{Note}

1. The four Health Insurance Companies, were: Zorgverzekeraar Zorg \& Zekerheid (Leiden), Zorgverzekeraar VGZ (Midden Brabant [Tillburg]) and VGZ/BAZ [Nijmegen]), and CZ group Zorgverzekeringen (Tilburg). 


\section{PART III}

\section{Results of the Study}





\section{Physiotherapist's Consultation in General Practice Its Use and Effect on Process of Care}

\section{Abstract}

Background and Purpose. Physiotherapist's consultation can be instrumental in enhancing the quality of patient care, particularly if the GP is uncertain as to whether physiotherapy will be beneficial. The purposes of this study, conducted in the Dutch primary health care setting. was to evaluate the frequency of use of a one-time physiotherapist's consultation by a group of GPs given the option of referring patients for a one-time consultation, and its effect on GP's management decisions (referral patterns). Methods. A seven-month observation study was conducted with 59 pairs of randomly selected GPs and physiotherapists. Data were collected at the level of the GP, the physiotherapist, and the patient referred for a one-time physiotherapist's consultation. Selfadministered questionnaires (completed at the onset and completion of the study), consultation requests, standardized forms and treatment referral data from health insurance agencies were used to obtain data. The outcomes were the number and nature of consultation requests; patient characteristics, the GP's opinion on the outcome of consultation, and referral patterns. Results. The total number of referrals for consultation was 352 (mean $=5.9$ per GP, range $=0-20$ ), resulting in a mean referral rate of 4.7 per 1000 patients $(s d=4.6)$. Profiles of patients referred for a one-time consultation differed from national reference data of patients referred by their GP for physiotherapy treatment. The main reasons cited for consultation were the need for diagnostic information (26\%) and (2) the need to determine an indication for physiotherapy (29\%). In $94 \%$ of the cases, GPs evaluated the outcome of consultation requests to be satisfactory. Most GPs (93\%) agreed with the physio-therapist's recommendation, which resulted in $50 \%$ of cases being managed in a different manner than was intended before consultation. Conclusion. The results show that GPs used the opportunity for a one-time physio-therapist's consultation and that they were satisfied with the outcome and process of consultation. The findings suggest that a one-time physiotherapist's consultation is an appropriate and beneficial component of a GP's patient management process. 


\section{Introduction}

In the Netherlands, ${ }^{1,2}$ as in many other countries, ${ }^{3,4}$ primary care physicians, often called general practitioners (GPs), occupy a pivotal position in the provision of primary care that is focused on patient diagnosis, intervention, prevention and continuity of care. The current emphasis on cost containment in the health sector highlights the role of GPs as "gatekeepers" to various health care services. Since most health services are accessible through written referral from the GP, this pivotal position of the GP implies that they have a thorough knowledge of the scope and breadth of practice of other health care professionals.

Patients with disorders of the locomotor, cardiovascular and respiratory systems represent the most prevalent groups treated by GPs. ${ }^{3.7}$ In The Netherlands, approximately $80 \%$ of patients in primary care physiotherapy practices are referred by GPs ${ }^{8-14}$ and 1 out of every 4 patients with disorders of the locomotor system are referred to a physiotherapist or medical specialist..$^{7,12}$

Because of this high referral rate, communication between GPs and physiotherapists is crucial. However, specific problem areas between these disciplines have been identified, including: poor communication, ${ }^{13-15}$ insufficient GP knowledge about physiotherapy, ${ }^{8.10 .14-17}$ unclear indications for referral, ${ }^{8.10,16,17}$ and questions about the efficacy and effectiveness of physiotherapy. ${ }^{18 \cdot 21} \mathrm{~A}$ request by a GP for a one-time physiotherapist's consultation prior to referral provides one option for improving the appropriateness of patient referral. . $^{8} 10.22,23$ If the GP is uncertain as to whether physiotherapy will be beneficial to a given patient, a consultation mechanism provides a valuable tool to enhance the communication between both professionals. This could improve the utilization of physiotherapy services, and institute a philosophy of shared care. ${ }^{22.23}$

Questions about the definition of an appropriate referral or the prevention of unnecessary referrals emphasize the need to develop strategies to improve the quality of referral, and the efficiency of physiotherapy services. This need is illustrated by large variations in the kinds and numbers of patients referred by GPs to physiotherapists. ${ }^{8.10,24-30}$ Factors that may coniribute to the variation in GP referrals include: the patient's health status, ${ }^{8,10,16,17,30,31}$ the GP's sociodemographic and personal characteristics, ${ }^{10,28,29}$ the GP's individual approach to patient care, the GP's attitude and referral behavior toward physiotherapy. ${ }^{8.10 .16 \cdot 17.30 .31}$ Furthermore, there is evidence to suggest that the number of patient referrals to physiotherapists may be associated with the GPs' knowledge about physiotherapy, their perception of physiotherapist's diagnostic capability, and their beliefs in the efficacy of physiotherapy treatment. $10,22,23.31,32$

By enabling GPs to consult physiotherapists, a new dimension to the relationship between GPs and physiotherapists can be introduced. Physiotherapist's consultation in the context of this study was defined as "a written request by a GP to a physiotherapist to examine and evaluate a patient to generate information regarding diagnosis and prognosis to facilitate the treatment plan of the GP, specifically when it concerns the possibilities 
for physiotherapeutic interventions. ${ }^{n 23.32 .33} \mathrm{~A}$ one-time consultation is not intended to create free access to the physiotherapist; it only takes place at the request of a GP, without sacrificing the GP's responsibility for care, and the continuity of care for the patient.

Physiotherapist's consultation by GPs doesnot appear to have been reported in the literature. ${ }^{22.32,34}$ This study investigated the frequency of use of consultation, what sort of information was requested by GPs, their opinion of the outcome of consultation, and their management decisions (referral patterns) following the consultation. In addition, we explored to what extent the demographic and personal characteristics of the GP and physiotherapist, and the demographic and clinical characteristics of the patient, influenced GP referral policies for patient management, their opinion of the process and outcome of consultation, and the number of consultation requests.

\section{Methods}

\section{Design}

A before-and-after observational study was conducted. ${ }^{35}$ During a 7 -month interval, GPs were given the opportunity to use physiotherapists as consultants. A random sample of 72 physiotherapists working in primary care was drawn from the total physiotherapist population (as registered in the Nivel-database) in four different regions of The Netherlands $(n=1533)$. The selected physiotherapists were stratified by degree of urbanization (i.e. rural, semi-urbanized, or urban), since GP referral patterns tend to be related to the geographical location of both GPs and patients. ${ }^{6.10 .32 .36}$ Once a physiotherapist agreed to participate, a GP was randomly selected from a list of GPs who usually referred to that physiotherapist, matched by degree of urbanization, and paired with the physiotherapist for the purpose of the study. If a selected GP did not agree to participate, another GP was randomly selected from the list until a match was made. ${ }^{32}$ The physiotherapists received an additional fee for each referral for a one-time consultation. The GPs received a set fee for participating in the study irrespective of the number of consultation requests they made.

\section{Process of consultation}

The process of a one-time physiotherapist's consultation by written communication was as follows: (1) The GP is undecided as to the possible benefit of physiotherapy. (2) The GP decides to consult a physiotherapist.(3) The GP communicates the reason for the request for consultation and the patient's clinical status to the physiotherapist. (4) The physiotherapist evaluates the patient's condition and functional status. (5) The physiotherapist communicates the findings and treatment recommendations in a written document presented to the GP. (6) The GP evaluates the additional physiotherapy information and the recommendations of the physiotherapist, and decides on the preferred patient management. 
No attempt was made to influence GP's management decisisons. All patients received information about the purpose and procedures of the study.

\section{Data collection}

Data were collected at the level of the GP, the physiotherapist, and at the level of the patient referred for a one-time consultation. Self-administered questionnaires given at the onset and completion of the study, consultation requests, standardized forms, and treatment referral data from health insurance agencies were used to obtain data. The development of the questionnaires was based on the literature. ${ }^{10.16 .17}$ Items for the questionnaires used in this study were field-tested and selected following a feasibility study. ${ }^{23}$

The group characteristics of the GPs and the physiotherapists were collected using selfadministered questionnaires given at the onset of the study. These questionnaires identified personal and practice characteristics of both groups, as well as the GPs" perceptions of physiotherapy.

The personal and practice characteristics consisted of the following: gender, age group. years of practice, postgraduate education, number of partners, and personal list size (total number of registered patients per GP). The GPs' perception of physiotherapist's knowledge, level of cooperation, and diagnostic capabilities, as well as their belief in the efficacy of physiotherapy were measured on a 5-point Likert scale. The Likert scale responses ranged from "poor" to "excellent" (1-5). The GPs' referral behavior toward physiotherapy, in the case of diagnostic uncertainty or doubt about the indication for physiotherapy, were also measured on at 5-point Likert scale, with the scale responses ranging from "never" to "very often" (1-5). At the level of the patient and consultation, the characteristics were collected during the process of consultation using standardized consultation forms. Characteristics of the patient consisted of the following: gender, age group, health insurance, level of education, employment, and marital status. The healthrelated characteristics were: the medical diagnosis, duration of the complaint(s), prior diagnostic and/or therapeutic medical interventions, and prior visits to other health professionals for the same complaint in the past 12 months.

Characteristics of the physiotherapist's consultations included: the reason for each consultation, the date of request, date of patient appointment, date the consultation was provided to the GP, the recommendations of the physiotherapist, and the GP's evaluation of the consultation process and the extent to which the consultation question was answered and reported.

The GP's consultation request form was developed according to the guidelines for referral of the Dutch Society of General Practitioners (NHG) ${ }^{37}$ The physiotherapist's consultation report form was developed according to the guidelines for documentation of the Royal Dutch Physiotherapy Association (KNGF). ${ }^{38}$ The medical diagnosis, referral diagnosis, referral data and types of complaints were classified according to the International Classification of Primary Care (ICPC) ${ }^{30}$ The patient's functional status was classified in terms of the International Classification of Impairments, Disabilities, and Handicaps $(\mathrm{ICIDH})^{40,41}$ as proposed by Heerkens et al. ${ }^{42.43}$ In a reliability study the intra- and 
interobserver reliability of the selected impairments and disabilities was found to be sufficient high. ${ }^{4}$

At the conclusion of the seven-month study interval, questionnaires given to both the GPs and physiotherapists asked for responses relevant to the appropriateness and practicality of the consultation referral and consultation forms, and the willingness of GPs and physiotherapists to continue with this process of consultation.

To evaluate the effects of consultation on current patient referral and treatment patterns, the patient and treatment characteristics from this study were compared with data of 17,201 patients included in the Netherlands' national health care database. ${ }^{45,46}$ Comparisons were concerned primarily with patient characteristics and content of physiotherapy care.

To investigate the effect of a one-time physiotherapist's consultation on referral patterns two kinds of information were used: (1) patient management decisions made after each consultation were compared to the intended plan (fictitious policy) of care prior to the physiotherapist's consultation, and (2) referrals to physiotherapists 2 or medical specialists following consultation were compared with national referral rates from the same interval in the previous year. The fictitious policy is defined as the policy the GPs reported they might have adopted if a referral for a one-time consultation had not been available. The referral rate was defined as the numerator representing the actual number of referrals per year and the denominator representing the total number of patients in the GP practice (list size). ${ }^{47}$

To detect significant changes in rates of referral (health insurance figures), between the experimental and control period, with an expected chance to be referred by a GP of $16 \%$ and $8 \%$ to a physiotherapist or orthopedic surgeon after the consultation, respectively, the minimum estimated number of consultation requests was 800 (with a type I error of 0.05 [two-tailed] and a type II error of 0.20 ) when we assume a difference of interest of at least $20 \%$.

\section{Outcome measures}

Outcome measures from the perspective of the GP were: (1) the number and nature of consultation requests, (2) patient characteristics, (3) their opinion of the outcome of consultation, (4) their compliance with the physiotherapist's recommendation, and (5) their management decisions (treatment referral patterns).

The main outcome variables were the GP's opinion of the outcome of consultation, and their treatment referral pattern after consultation.

Criterion variables under study were: (1) the total number of consultation requests; (2) the extent to which the GP thought the consultation question was answered satisfactorily (for the purpose of the analysis, the satisfaction measure on a 5-point Likert scale was dichotomized into high [excellent] versus low satisfaction [poor, slight, fair, substantial]); and (3) whether or not the intended (fictitious) treatment policy, compared with the actual treatment policy after consultation, was changed. 
Table 1. Characteristics of the participants

\begin{tabular}{|c|c|c|c|c|}
\hline \multirow[t]{2}{*}{ Characteristics } & \multicolumn{3}{|c|}{$\begin{array}{r}\text { General } \\
\text { Practitioners } \\
(\mathrm{n}=59)\end{array}$} & \multirow{2}{*}{$\begin{array}{r}\begin{array}{r}\text { Physical } \\
\text { Therapists } \\
(\mathrm{n}=59)\end{array} \\
(\%)\end{array}$} \\
\hline & No. & (\%) & No. & \\
\hline Gender (male) & 55 & $(93 \%)$ & 37 & $(63 \%)$ \\
\hline \multicolumn{5}{|l|}{ Age } \\
\hline$<35$ & 3 & $(5 \%)$ & 24 & $(41 \%)$ \\
\hline $35-45$ & 31 & $(53 \%)$ & 28 & $(47 \%)$ \\
\hline $45-55$ & 19 & $(32 \%)$ & 6 & $(10 \%)$ \\
\hline$>55$ & 6 & $(10 \%)$ & 1 & $(2 \%)$ \\
\hline \multicolumn{5}{|l|}{ Years in practice } \\
\hline$<5$ & 6 & $(10 \%)$ & 4 & $(7 \%)$ \\
\hline $5-10$ & 18 & $(31 \%)$ & 20 & $(34 \%)$ \\
\hline$>10$ & 35 & $(59 \%)$ & 35 & $(59 \%)$ \\
\hline Postgraduate education " (yes) & 46 & $(78 \%)$ & 55 & $(93 \%)$ \\
\hline$\leq 2$ courses & $\bullet$ & & 21 & $(36 \%)$ \\
\hline sports physical therapy & - & & 15 & $(25 \%)$ \\
\hline manual therapy & $\bullet$ & & 17 & $(29 \%)$ \\
\hline Perception of physical therapy ${ }^{b}$ & Median & (Range) & & \\
\hline knowledge about physical therapy & 3 & $(1-4)$ & - & \\
\hline diagnostic skills of PTs & 4 & $(3-5)$ & - & \\
\hline efficacy of physical therapy & 4 & $(2-5)$ & - & \\
\hline cooperation with PTs & 4 & $(1-5)$ & - & \\
\hline Frequency of communication ( $\leq 1$ per month) & 39 & $(66 \%)$ & - & \\
\hline Referral behavior toward physical therapy ${ }^{\mathrm{c}}$ & Median & (Range) & & \\
\hline referral with uncertainty indication & 2 & $(1-5)$ & - & \\
\hline referral for appropriateness indication & 2 & $(1-5)$ & - & \\
\hline advise by telephone prior to decision of referral & 2 & $(1-5)$ & - & \\
\hline \multicolumn{5}{|l|}{ Number of partners } \\
\hline single-handed practice & 28 & $(47 \%)$ & 7 & $(12 \%)$ \\
\hline$>1$ partner & 31 & $(53 \%)$ & 52 & $(88 \%)$ \\
\hline \multicolumn{5}{|l|}{ Personal list size } \\
\hline$<2000$ & 7 & $(12 \%)$ & - & \\
\hline $2000-2350$ & 13 & $(22 \%)$ & - & \\
\hline $2350-2700$ & 21 & $(35 \%)$ & - & \\
\hline $2700-3050$ & 13 & $(22 \%)$ & - & \\
\hline$>3050$ & 5 & $(9 \%)$ & - & \\
\hline Level of urbanization (urban areas) & 17 & $(29 \%)$ & 17 & $(29 \%)$ \\
\hline
\end{tabular}

Concerning the locomotor system

5-point Likert scale (poor |1] - excellent [5])

5-point Likert scale (never [I] - very often/5/)

- Nor applicable 


\section{Analysis}

Statistical methods included a chi-square test for independent proportions (categorical variables) or, when appropriate, a student t-test (continuous variables) for comparison of group means and for paired observations. In all cases a two-tailed level of $p \leq 0.05$ was set as significant.

The initial analysis examined the bivariate relationships between the predictor variables, and the criterion variables (i.e. the number of referrals for a one-time consultation, the GP's opinion of the outcome of consultation, and the changes in treatment policy). Those variables significantly related with the criterion variables were retained for further analysis.

The simultaneous influence of various predictor variables on the total number of referrals for a one-time consultation was examined stepwise by multiple linear regression analysis. (SPSS-PC for Windows, version 6.1.2). The simultaneous influence of the predictor variables on (1) the GPs' opinions and (2) changes in treatment policy were examined by logistic multi-level analysis (MLA). ${ }^{48}$ Predictor variables were entered in four blocks: (1) characteristics of the patient, (2) the consultation, (3) the GP, and (4) the physiotherapist, respectively.

The MLA was used because the data set had an intrinsically hierarchical nature in which patients (lower level) are nested within GPs (higher level). Because referred patients of one GP are more alike than patients of different GPs, the patients cannot, a priori, represent completely independent observations. By applying the statistical linear regression tool of hierarchical linear modeling, ${ }^{48-50}$ potential clustering of data was taken into account. This permitted analysis of data without aggregation of patient data to the GP level, or distribution of patient characteristics to the GP level. A traditional linear analysis may have resulted in loss of valuable information, whereas the hierarchical analysis preserves independence of information (see for example Kerssens et al. ${ }^{\text {s!) }}$ ) The strength of the associations was assessed by means of non-standardized regression coefficients (B) or odds ratios $(\mathrm{OR})$ and $\mathrm{p}$-values.

\section{Results}

\section{Representation of the participants}

The willingness to participate in the study for physiotherapists and GPs was $86 \%(62 / 72)$ and $74 \%(62 / 84)$, respectively. Of the 62 GP-physiotherapist pairs originally created, 59 completed the study and were included in data analysis, due to 3 GPs withdrawing from the study for personal reasons. Table 1 lists the characteristics of the participants. A comparison of the data on the study's GPs and physiotherapists, with that of all GPs $(n=6,548)^{52}$ and physiotherapists $(n=10,187)^{53}$ in primary care (The Netherlands), indicated that the study's GPs appeared to be representative of classifications of gender, age, years of establishment in practice, list size, and number of partners. 
Table 2. Comparison of demographic characteristics for patients referred for a one-time physical therapy consuliation with patients listed in the national database of patients referred by GPS for receiving physical therapy treatment

\begin{tabular}{|c|c|c|c|c|}
\hline \multirow[b]{2}{*}{ Characteristics } & \multicolumn{2}{|c|}{$\begin{array}{r}\text { Consultation } \\
(\mathrm{n}=352) \\
\end{array}$} & \multicolumn{2}{|c|}{$\begin{array}{r}\text { Treatment } \\
(\mathrm{n}=17,201)\end{array}$} \\
\hline & No. & $(\%)$ & No. & $(\%)$ \\
\hline \multicolumn{5}{|l|}{ Demography } \\
\hline Gender (female) & 187 & $(53 \%)$ & 9,357 & $(54 \%)$ \\
\hline \multicolumn{5}{|l|}{ Age $(\text { nmiss }=4)^{* t}$} \\
\hline $0-24$ & 94 & $(27 \%)$ & 2,425 & $(14 \%)$ \\
\hline $25-44$ & 143 & $(41 \%)$ & 6,743 & $(39 \%)$ \\
\hline $45-64$ & 87 & $(25 \%)$ & 5,246 & $(31 \%)$ \\
\hline $65+$ & 24 & $(7 \%)$ & 2,769 & $(16 \%)$ \\
\hline \multicolumn{5}{|l|}{ Health insurance } \\
\hline Public health insurance & 263 & $(75 \%)$ & 12,643 & $(74 \%)$ \\
\hline \multicolumn{5}{|l|}{ Education (nmiss $=6)^{*}$} \\
\hline low & 150 & $(43 \%)$ & 10,427 & $(61 \%)$ \\
\hline middle & 154 & $(44 \%)$ & 5,428 & $(32 \%)$ \\
\hline high & 42 & $(12 \%)$ & 1,347 & $(8 \%)$ \\
\hline Employed (yes)* & 172 & $(49 \%)$ & 5,785 & $(34 \%)$ \\
\hline Marital status (single)* & 33 & $(9 \%)$ & 2,563 & $(15 \%)$ \\
\hline
\end{tabular}

$X^{2}: p<0.01$

The physiotherapists were representative of gender, age, and type of postgraduate education, but were more experienced in terms of years of establishment. Physiotherapists from single-handed practices were under-represented. ${ }^{32}$

\section{Frequency of use and reason for consultation}

During the 7-month study, 352 patients were referred for a one-time physiotherapist's consultation by 53 GPs (mean $=5.97$, median $=5$, range $=0-20$ ). Six GPs did not refer any patients for consultation. None of the patients refused the referral for physiotherapist's consultation. However, 10 patients preferred to see a physiotherapist of their own choice, and not one of the therapists participating in the study. The mean referral rate was 4.7 per 1000 patients per year $(\mathrm{sd}=4.6$; range $=0-21.4)$. The referral rate for consultation by GPs located in urban areas was higher (borderline significant, $\mathrm{p}=0.051$ ) than in rural areas. The reasons for referral were: for information on diagnosis and health status ( $92 / 352$ [26\%]); indication for physiotherapy (102/352 [29\%]); or both (158/352 [45\%]). Frequently mentioned additional reasons were: a second opinion from a physiotherapist's perspective $(96 / 352[27 \%])$; to support the intended plan of care of the GP $(55 / 352$ $[16 \%])$; and prevention of referral to a medical specialist $(44 / 352$ [12\%]). 
Table 3. Comparison of health status related characteristics for patients referred for a one-time physiotherapist's consultation with patients listed in the national database of patients referred by GPs for receiving physical therapy treatment

\begin{tabular}{|c|c|c|c|c|}
\hline \multirow[b]{2}{*}{ Characteristics } & \multicolumn{2}{|c|}{$\begin{array}{r}\text { Consultation } \\
(\mathrm{n}=352)\end{array}$} & \multicolumn{2}{|c|}{$\begin{array}{r}\text { Treatment } \\
(\mathrm{n}=17,201)\end{array}$} \\
\hline & No. & (\%) & No. & (\$) \\
\hline \multicolumn{5}{|l|}{ Health status } \\
\hline \multicolumn{5}{|l|}{ Duration complaints (nmiss $=6$ ) ${ }^{*}$} \\
\hline$<1$ week & 15 & $(4 \%)$ & 2.597 & $(15 \%)$ \\
\hline 1 week - 12 weeks & 137 & $(39 \%)$ & 9,512 & $(58 \%)$ \\
\hline 13 weeks - 1 year & 99 & $(29 \%)$ & 1,496 & $(18 \%)$ \\
\hline$>1$ year & 97 & $(28 \%)$ & 1,565 & $(9 \%)$ \\
\hline Prior physical therapy same complaint (yes) * & 56 & $(16 \%)$ & 6,261 & $(36 \%)$ \\
\hline \multicolumn{5}{|l|}{ Prior medical diagnostic / therapeutic actions * } \\
\hline Radiography & 103 & $(29) \%$ & 5,659 & $(33 \%)$ \\
\hline Laboratory & 22 & $(6 \%)$ & 189 & (1\%) \\
\hline Surgery & 12 & (3\%) & 1,772 & $(10 \%)$ \\
\hline Medication/injection & 58 & $(16 \%)$ & 7,172 & $(42 \%)$ \\
\hline Cast/tape & 12 & $(3 \%)$ & 722 & $(4 \%)$ \\
\hline \multicolumn{5}{|l|}{ Type of disorder in terms of ICPC } \\
\hline Knee (L15) & 61 & $(17 \%)$ & 533 & $(3 \%)$ \\
\hline Back (LO2) & 58 & $(16 \%)$ & 1.049 & $(6 \%)$ \\
\hline Lower extremity (L.14) & 30 & $(9 \%)$ & 722 & $(4 \%)$ \\
\hline Shoulder (L08) & 27 & $(8 \%)$ & 1,376 & $(8 \%)$ \\
\hline Neck (LO1) & 22 & $(6 \%)$ & 1,686 & $(10 \%)$ \\
\hline Upper extremity (LO9) & 16 & $(5 \%)$ & 756 & $(4 \%)$ \\
\hline Thigh (L13) & 14 & $(4 \%)$ & 206 & $(1 \%)$ \\
\hline Ankle (L16) & 11 & $(3 \%)$ & 189 & $(1 \%)$ \\
\hline Other complaints (L29) & 11 & $(3 \%)$ & 189 & $(1 \%)$ \\
\hline Elbow (L10) & 9 & $(3 \%)$ & 68 & $(1 \%)$ \\
\hline Subtotal & 246 & $(74 \%)$ & 6,774 & $(39 \%)$ \\
\hline
\end{tabular}

$$
X^{2}: p<0.01
$$

International Classification of Primary Care (ICPC) (top-10 of referrals for consultation) ${ }^{\text {to }}$

\section{Patient characteristics}

In Table 2, an overview is given of patients" demographic characteristics in this study compared with those from the Netherlands' national database for treatment referrals. ${ }^{29}$ The groups differed in age, level of education, employment and marital status. The patient group undergoing consultation in this study had a greater percentage of patients below the age of 25 , a lower percentage older than 65 , and a greater percentage of patients with a high-level education compared to the national data.

In both this study group and the national database, almost all patients were referred for treatment due to complaints of the locomotor system ( $97.5 \%$ vs $87.5 \%)$. Very few patients were referred with disorders of the neurological system $(2.5 \%$ vs $7.8 \%)$. 
Table 4. Linear regression results (non-standardized regression coefficients [B]) for patient, GPs (and practice setting), and PTs characteristics associated with the number of consultation requests $(n=352)$

Proportian

or median
Number of

consultations

Predictor variables

B

\section{Level 1:}

Charactertistics of patients $(n=342)$

gender (female)

0.53

$-0.72$

age $(<25$ year $)$

0.27

2.1

insurance (public health insurance)

0.75

2.11

education (low)

0.43

$-0.35$

marital status - (single)

0.09

$-2.81$

duration of complaints ( $\leq 12$ weeks) ${ }^{2}$

0.43

4.31 *

\section{Characteristics of consultation}

request for diagnostic information (yes)

request for indication physical therapy (yes)

\section{Level 2:}

\section{Characteristics of GPs $(n=59)$}

knowledge about physical therapy ${ }^{\text {b }}$ perception of diagnostic skills of PTs ${ }^{\text {" }}$ perception of efficacy of physical therapy ${ }^{b}$ perception of the cooperation with $\mathrm{PT}^{\mathrm{b}}$ frequency of communication ( $\leq$ I per month) experience (years in practice) ${ }^{c}$ postgraduate education (yes) referral with uncertainty about indication " referral for appropriateness about indication ${ }^{\circ}$ advise by telephone prior decision of referral ${ }^{\complement}$

Characteristics of practices number of partners (single-handed)

\section{Characteristics of PTs $(n=59)$}

- Significant level set at $p \leq 0.05$

" Dichotomized in low (poor [1], slight /21, fair [3], substantial /4]) versus high (excellent [5]) satisfaction

- Measured on a 5-point ondinal scale (poor [I] - excellent [S])

'Measured on 3 categories (< 5 year $\mid 1]$; 5.10 /2]: > 10 year $[3])$

"Measured on a 5-point ondinal scale (never [I] - very often [5]]

- Variable not in analysis 
In Table 3 an overview is given of the patient's health status related characteristics. When compared to the national database, a greater percentage of patients in the consultation group were referred with complaints of knee pain, back pain, and "other pain in the leg." In $57 \%$ (196/352) of the patients, the duration of complaints was longer than 12 weeks, and very few patients had acute complaints (of less than one week).

Patients referred for consultation had less contact with physiotherapists prior to consultation and had undergone less medical diagnostic and/or therapeutic interventions. compared to the national database group.

In an effort to explore the source of variation in the number of referrals for a one-time consultation, multivariate linear regression analysis indicated that the predictor variables "patients with complaints of more than 12 weeks," and "GPs with a smaller list size" were positively related with the frequency of use of consultation requests (Table 4).

\section{Opinion on the outcome}

The opinion of the GP on the outcome of consultation was evaluated on the level of each consultation and on the GP level via a questionnaire. Because 10 patients did not receive consultation by a therapist in the study, results of only 342 referrals could be evaluated. In $94 \%(321 / 342)$ of the consultation requests, the GPs were of the opinion that the physiotherapy reports had answered their questions "excellently" (219/342 [64\%]), or "substantially" (102/342 [30\%]). In the remaining cases, their opinion was reported as "fair" (11/342 [3\%]) or "slight" (10/342 [3\%]).

Predictor variables significantly associated with whether or not the request was excellently performed and reported are given in Table 5. Hierarchical (multi-level) logistic regression analysis suggests that GPs were less satisfied with the outcome of consultation when the request was directed to additional diagnostic information only. GPs who were initially less positive about cooperation with physiotherapists, GPs who were more positive about the diagnostic skills of physiotherapists, and GPs who had insufficient knowledge about the indications for physiotherapy were more often satisfied with the outcome of consultation. Furthermore, the opinion of the GP was positively related to the physiotherapist's level of experience in advising GPs (informal consultations), the number of postgraduate educational courses, and physiotherapists skilled in manual therapy. The final explained variance of the significant associated predictor variables was approximately $35 \%$. A stepwise analysis revealed that the largest proportion of explained variance was derived from significant characteristics of physiotherapists $\left(\mathrm{R}^{2}=22 \%\right)$ and less by the GP's characteristics $\left(\mathrm{R}^{2}=11 \%\right)$.

Results from the questionnaire at the conclusion of the study indicated that all GPs received all physiotherapist's consultation report forms within an appropriate amount of time; $44 \%(26 / 59)$ of the GPs indicated that the consultation had been "often or very often" useful for their decision making; $30 \%$ (18/59) indicated that this had been the case "sometimes". Almost all GPs (55/59 [93\%]) indicated that the recommendations of the physiotherapist were "substantially" or "excellently" founded on a sound rationale. Eightysix percent $(51 / 59)$ of the GPs believed that the process of consultation could easily be 
incorporated into their daily practice. Eight percent (5/59) of the GPs indicated that they would find this difficult and 5\% (3/59) gave no opinion. The GPs were generally satisfied with the consultation request form for allowing the physiotherapist insight into the patient's condition. The average amount of time taken to complete the form (including the research questions) was $3 \mathrm{~min}$ (range $=1-6 \mathrm{~min}$ ). Seven out of ten GPs indicated that they would like to continue with the opportunity of physiotherapist's consultation in the future.

\section{Recommendation and patient management}

Of the 342 consultations included in the analysis, 10 recommended multiple options for treatment referral. The data analysis was therefore restricted to the 332 that presented a clear choice for the GP. The GPs were compliant with the recommendations of the physiotherapist in $93 \%$ (310/332) of the cases and there was no significant difference between the recommendations of the physiotherapist and the actual management policy of the GP $\left(\mathrm{X}^{2}=3.16, \mathrm{df}=3, \mathrm{p}=0.368\right)$. In $7 \%(23 / 332)$ of the cases, the GP did not comply with physiotherapist's recommendations. The physiotherapists were of the opinion that in $71 \%(235 / 332)$ of the consultations physiotherapy was indicated.

Table 6 compares the management decision that the GP would have made if the physiotherapist had not been consulted, with the actual decision made following (the experimental opportunity) of a one-time consultation. The data suggest that consultation resulted in fewer patients being referred to medical specialists ( 55 vs $101 ; \mathrm{p}=0.001$ ) and more to physiotherapists ( 232 vs $181 ; \mathrm{p}=0.018$ ). Caution should be exercised in interpreting these changes in referral pattern since the changes are more complex than the marginal totals of the table indicate. Table 6 shows that of the 101 patients that would have been referred to a medical specialist, 67 were instead referred for physiotherapist treatment, 11 were treated by the GP, and 21 were actually referred to a medical specialist. With more than $50 \%$ of the patients $(138 / 332)$, the intended treatment policy of the GP presumably changed on the basis of the information and recommendations obtained through the physiotherapist's consultation. Taking into account a distinction between referral to medical specialists for consultation or treatment, the intended treatment policy was changed in $68 \%$ of the consultations (not shown in table).

The predictor variables as listed in Table 5 indicated that a change in the GP's intended treatment policy was negatively related to age (lower age groups) and level of education (low) in the patient group, and positively related to the opinion of the GE regarding outcome of the consultation and his or her frequency of communication with the physiotherapist.

Differences in mean referral rates to physiotherapists or medical specialists between this study and the national database (including subgroup analysis of referral rates to orthopedists, neurologists, rheumatologists and physiatrists) were not significant ( $p=0.37$ and $p=0.40$, respectively: Table 7). There was also no relationship between the number of consultations per GP and changes (differences) in their total number of referrals to physiotherapists $(r=0.046, p=0.74)$ and medical specialists $(r=-.19, p=0.18)$ during the study and database intervals investigated (Table 7). ${ }^{32}$ 
Table 5. Hierarchical (multi-level) logistic regression results (odds ratios [OR]) of patient, GP (and practice) and PT characteristics associated with (l) the opinion of GPs on the consultation report and (2) whether or not their intended management policy (before consultation) was changed "

Multi-level

logistic regression analysis
(1) Opinion
(2) Policy changed

Predictor variables

OR

OR

\section{Level 1:}

Charactertistics of patients $(\mathrm{n}=342)$

gender (female)

$\begin{array}{ll}0.78 & 0.86\end{array}$

age ( $<25$ year)

insurance (public health insurance)

0.89

0.52 *

education (low)

0.90

0.86

marital status - (single)

1.12

$0.61 \cdot$

duration of complaints ( $\leq 12$ weeks)

1.0

1.20

0.89

1.12

Characteristics of consultation

request for diagnostic information (yes)

reques for indication physical therapy (yes)

0.34 * 0.94

opinion of the reporn (low satisfaction) ${ }^{b}$

0.58

1.03

\section{Level 2:}

\section{Characteristics of GPS $(n=53)$}

knowledge about physical therapy ${ }^{\circ}$

perception of diagnostic skills of PTs ${ }^{\mathrm{c}}$

perception of efficacy of physical therapy"

perception of the cooperation with $\mathrm{PT}^{\mathrm{c}}$

frequency of communication ( $\leq 1$ per month)

experience (years in practice) ${ }^{d}$

(post)graduate education (yes)

referral with uncertainty about indication ${ }^{\text {s }}$

referral for appropriateness about indication ${ }^{e}$

advise by telephone prior decision of referral ${ }^{c}$

\section{Characteristics of PTs $(n=53)$}

experience (years in practice) ${ }^{\triangleleft}$

experience with (informal) consultation *

\begin{tabular}{|c|c|c|}
\hline 0.36 & * & 0.88 \\
\hline 3.35 & * & 1.07 \\
\hline 1.82 & & 1.04 \\
\hline 0.52 & * & 1.02 \\
\hline 0.84 & & $1.24 *$ \\
\hline$[.1]$ & & I. .22 \\
\hline 1'. 80 & & 1.62 \\
\hline 0.86 & & 0.76 \\
\hline 1.22 & & 0.90 \\
\hline 0.84 & & 1.19 \\
\hline
\end{tabular}

(post)graduate education ( $\leq 2$ courses)

$1.08 \quad 0.81$

sports physical therapy (yes)

$2.16 * 0.97$

$15.33 * 1.02$

manual therapy (yes)

1.28

0.70

$5.21 * 0.76$

- Significant level set at $p \leq 0.05$

- 342 level-1 variables (patients/consuitations) and 53' level-2 variables (GPs and PTs).

- Measured on a 5-point ordinal scale but dichotomized in low (= poor $[1]$, slight $(2)$. fair $(3)$. substantial /4) versus high (= excellent [S]) satisfaction

4. Measured on a 5-point ordinal scale (poor [1] - excellent [5]).

a Measured on 3 categories $(<5$ year $[1]$ : $5-10$ /2/: > 10 year $(3)$ )

- Measured on a 5-point ordinal scale (never [I] - very often [5],

- Variable not in analysis. 


\section{Comment}

The results of this study demonstrate that a one-time physiotherapist's consultation in general practice is feasible and affects GiPs' management policies. Both the group of GPs and the group of physiotherapists (as presented in a seperate paper) ${ }^{54}$ participating in the study found the process of consultation by written communication to be effective and easily incorрогаted into their daily practice. Although considerable variation was found among the GP referrals, the group was generally satisfied with the process and outcome of consultation. This was especially true of the GPs who reported prior to the study that they were not completely knowledgeable about the role of physiotherapy and the diagnostic capabilities of physiotherapists. Interestingly, the GPs who indicated that their cooperation with physiotherapists was not ideal prior to the study more often stated that they were completely satisfied with the physiotherapist's consultation and the relevance of information for directing treatment. In general, the GPs were more satisfied when they had consulted more experienced and skilled physiotherapists. In this respect, it should be noted that physiotherapists with relatively little experience more often decined to participate, which may have influenced the generalization of results. ${ }^{32}$ For the purpose of the analysis, the satisfaction measure (opinion on the outcome of consultation) was dichotomized into high satisfaction (excellent) and low satisfaction (substantial, fair, slight, poor). This was because of the possibility that respondents would opt for the "substantial" option as a way to avoid expressing very positive (rating of excellent) or very negative (rating of slight or poor) opinions on the result of the consultation request. There is evidence that people are reluctant to express negative perceptions and to give socially desirable answers. ${ }^{55-57}$

Another point of interest is the finding that profiles of patients referred for a one-time consultation differed from historical records of patients referred for physiotherapy treatment. Patients with complaints less than 13 weeks, and patients from GP practices having larger list sizes were less often referred for a one-time consultation. Most. frequently, patients with disorders of the locomotor system were referred for consultation. The lower referral rate for a one-time consultation for patients with acute complaints may be related to the wait-and-see policy of many GPs and the expected course for normal recovery (natural history). If the course of the recovery was delayed, the potential for physiotherapist's consultation to prevent chronicity or disablement was increased. The relevance of list size may indicate the influence of increased workload affecting the GPs. behavior. ${ }^{32,47.58}$ The referral rate for a one-time physiotherapist's consultation by GPs in rural areas was substantially lower than in urban areas and is in concordance with the literature about the influence of referral rates to medical specialists by degree of urbanization of the practice location. ${ }^{6.32,47.38}$

It should be noted that GPs having low referral rates for physiotherapy treatment, due to the 2-stage selection procedure of the participants, were under-represented. However, additional analysis between low (lower quartile) and high referral rates for physiotherapy treatment (upper quartile) did not show a significant difference in the frequency of use of physiotherapist's consultation. 
Table 6. Treatment policy of GPs following a one-rime physiotherapist's consultation"

Before consultation

\begin{tabular}{|c|c|c|c|c|}
\hline $\begin{array}{l}\text { Continue } \\
\text { own } \\
\text { management }\end{array}$ & $\begin{array}{l}\text { Referral } \\
\text { to MS }\end{array}$ & $\begin{array}{l}\text { Referral } \\
\text { to PT }\end{array}$ & Other & $\begin{array}{l}\text { Total after } \\
\text { consultation }\end{array}$ \\
\hline
\end{tabular}

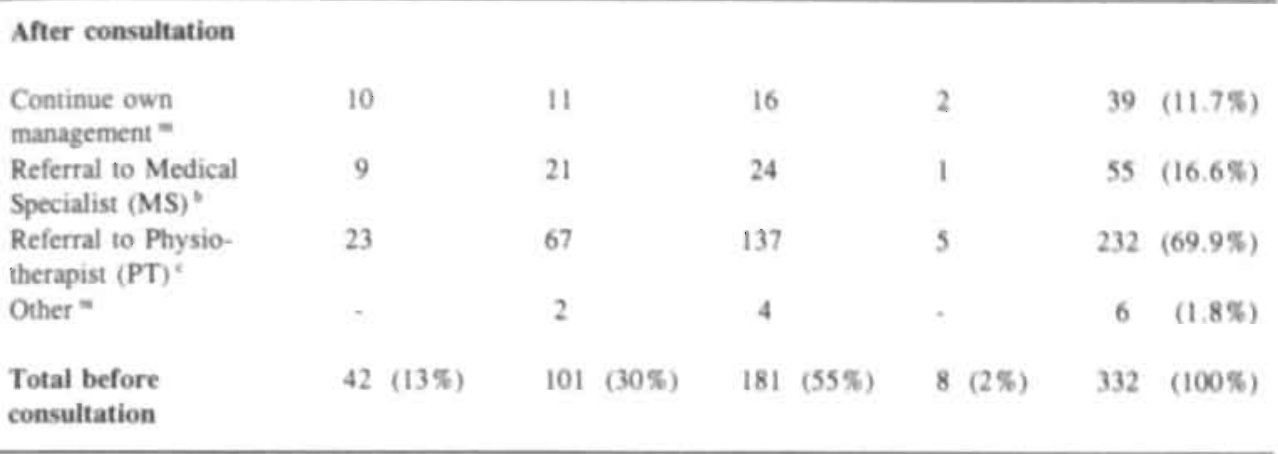

No distincrion is made for for treatment or consultation after a one-time physiotherapist's consultation Significant difference in number of referrals (before-and-after) to medical specialists $(p=0.018$; paired 1-lest) Significant difference in number of referrals (before-and-after) to physical therapists $(p=0.001$; paired 1 -test) Not significant

How should we interpret the frequency of use of physiotherapist's consultation? The referral rate for physiotherapist's consultation was low compared with the referral rate for treatment ( 4.9 vs 114 referrals per GP per 1000 patients per year) ${ }^{10}$ or compared with the feasibility study (12 per 1000 referrals). ${ }^{23}$ But what does this figure mean when compared with the referral rate for consultation with a medical specialist? The referral rate for a one-time physiotherapist's consultation seems to be comparable with medical specialist consultation (neurologist, 9.7; orthopedist/orthopedic surgeon, 9.4; rheumatologis, 2.3; physiatrist, 1.4 referrals per 1000 patients). ${ }^{59,60}$

The results also indicate that the treatment policy of the GP was often changed or adjusted because of the additional information obtained through the physiotherapist's consultation. We found that GPs who changed their policy were more satisfied with the outcome of consultation. Although the opinion of the GP on the outcome of consultation will not provide complete insight into variations in "patient demand," it is possibly the most important key variable in relation to their treatment decision. There was a substantial reduction in the number of referrals to medical specialists. From the physiotherapist's perspective, there was no indication for physiotherapy in 30\% (100/332) of the cases and in $46 \%(46 / 100)$ of the cases a referral to medical specialists was prevented. These findings suggest substitution of general care rather than referral to medical specialists as a result of the physiotherapist's consultation. However, interpretation of these findings should be cautious because of the uncontrolled nature of the study. Confirmation of a substitution effect on rates of referral was not possible, due to the study's limitation. ${ }^{32}$ 
In today's healih care sector, the quality and efficiency of care is a key factor in health care policy. Based on the results of this study, we suggest that physiotherapy can be used more efficiently if GPs utilize physiotherapist's consultation at an early stage of patient management. Consultation may be especially beneficial when the GP is uncertain about indications for and services provided in a changing, i.e., research-based physiotherapy practice. ${ }^{18-21,61,62}$ At present, GPs determine the need for physiotherapy based on the (bio)medical diagnosis of the patient. However, a medical diagnosis alone may not be a sufficient guide for physiotherapeutic intervention in today's physiotherapy practice. ${ }^{10.23,43 .}$ ${ }^{46,60-70}$ In recent years, physiotherapists have been encouraged to adopt a "biopsychosocial" model of health care, encompassing the physical, psychological and social characteristics of the patient. ${ }^{60.65-70}$ Physiotherapy is often directed to the impairments and disabilities related to locomotor disorders rather than to the disorder or disease itself. ${ }^{10,23,28.45 .46,61,64-70}$ Accordingly, physiotherapist's consultation could be educational for GPs, as it may improve their knowledge of the indications for physiotherapy, the skills of the physiotherapist, and the therapeutic potential of physiotherapy.

Physiotherapisi's consultation requires a different attitude and way of working of the physiotherapist, who is required to provide an opinion about the health status of a patient, the prognostic indications of outcome variables, and the indications for physiotherapy treatment. The patient prognosis, treatment goals, treatment approach and the number of treatment sessions need to be determined during a single consultation. At the same time, physiotherapists a!so have to take into account any ethical considerations, together with the prevailing regulatory framework, in their communication with the patient and the GP. The final responsibility for a patient's total management, however, lies with the GP, and emphasizes the need for great skill in interdisciplinary communication, and appropriate referral.

In conclusion, better communication about indications for physiotherapy between the GPs and physiotherapists participating in this study influenced the GiPs' referral patterns. Future studies are needied to assess the effects of a one-time physiotherapist's consultation over longer periods of time. It can be expected that a revised referral pattern following physiotherapist's consultation may lead to more efficient indication setting and utilization of physiotherapy services. However, pertaining uncertainty about the appropriateness of physiotherapy treatment following a one-time consultation and the capability of physiotherapists to predict the possible benefit of physiotherapy treatment, a one-time physiotherapist's consultation could also result in unneccessary referrals and overutilization of physiotherapy services.

The effects on utilization and efficiency of physiotherapy services of increased treatment referral to physiotherapy will be reported in a companion paper. 
Tabel 7. Differences in mean referral rates to physiotherapists and medical specialists before consultation (control period) and after consultation (experimental period)

\begin{tabular}{|c|c|c|c|c|c|c|}
\hline \multirow[b]{2}{*}{ Referrals * } & \multicolumn{2}{|c|}{$\begin{array}{r}\text { Before } \\
\text { consultation }\end{array}$} & \multicolumn{2}{|c|}{$\begin{array}{r}\text { After } \\
\text { consultation }\end{array}$} & \multirow{2}{*}{$\begin{array}{r}\begin{array}{r}\text { Difference } \\
\text { (p-value) }\end{array} \\
\text { mean }\end{array}$} & \multirow[t]{2}{*}{$\begin{array}{r}\text { Correlation coefficients } \\
\text { (p-value) }\end{array}$} \\
\hline & mean & (sd) & mean & (sd) & & \\
\hline Physiotherapists & 188.5 & 84.9 & 200.3 & 116.9 & $+11.8(0.37)$ & $+0.046(0.74)$ \\
\hline Medical specialists & 80.2 & 20.7 & 78.3 & 22.1 & - $1.9(0.40)$ & $0.190(0.18)$ \\
\hline
\end{tabular}

per 1000 patients per year

- pearson correlation coefficient

\section{References}

1. Landelijke Huisartsen Vereniging. Het basistakenpakket van de huisarts. Utrecht: LHV Vademecum, 1987.

2. Geijer RMM, Burgers JS, Laan van der JR, Wiersma TJ, Rosmalen CFH, Thomas S [Eds]. NHGStandaarden voor de huisarts, deel 1. Maarssen: Elsevier/Bunge, 1999.

3. Joint Working Party of the Welsh Council of the Royal College of General Practitioners and the Welsh General Medical Services Committee. Patient care and the general practitioner. Br Med J 1994:309:1 144-47.

4. American Board of Internal Medicine. A statement on the generalist physician from the American Boards of family practice and internal medicine. JAMA 1994;27I(4):315-16.

5. Jaarboek Ziekenhuizen. Utrecht:\$IG/Informatiecentrum voor de gezondheidszorg, 1992.

6. Velden J van der, Bakker DH de, Claessens AAMC, Schellevis FG. Nationale studie naar ziekten en verrichtingen in de huisartsenpraktijk. Basisrapport: Morbiditeit in de huisartsenpraktijk. Utrecht: Netherlands institute of primary health care (Nivel), 1991.

7. Lamberts H. In het huis van de huisarts. Verslag van het Transitieproject. Lelystad: Meditekst, 1991

8. Kerssens JJ, Groenewegen PP. Referrals to physiotherapy: The relation betweer the number of referrals, the indication for referral and the inclination to refer. Soc Sci \& Med 1990;30:797-804.

9. Rijken PM, van Heugten CM. Dekker J. Brancherapport paramedische zorg. Utrecht: Nederlands instituut. voor onderzoek van de gezondheidszorg (Nivei), 1996.

10. Kerssens JJ, Curfs Echr. Extramurale fysiotherapie. Utrechi, PhD dissertation. Netherlands Institute for primary health care (Nive!), 1993.

11. Centraal Bureau voor de Statistiek (CBS). Statistisch Jaarboek 1997. Voorburg: CBS, 1997.

12. Uunk W, Dekker J, Groenewegen P. Verwijzingen van huisartsen naar fysiotherapeuten: morbiditeitsspecifieke verwijspercentages. Deelproject Huisarts en fysiotherapeutische zorg: Basisgegevens uit de Nationale Studie van Ziekten en Verrichtingen in de Huisartsenpraktijk. Utrecht: Nivel, 1991.

13. Hulme JB, Wackernagel B, Lewis JW. Communication between physicians and physical therapists. Physical Therapy $1988 ; 68: 26-31$.

14. Stanton PE, Fox FK, Francois KM, Hoover DH, Spilecki GM. Assessment of resident physicians' knowledge of physical therapy. Physical Therapy 1985;65:27-30.

15. Vili RM, Shepard K, Savinar E. Physician knowledge and utilization of physical therapy procedures. Physical Therapy 1984:64:1623-1530.

16. Anderson J, Campbell SK. Correlates of physician utilization of physical therapy. International Journal of Technology Assessment in Health Care 1992;8(1):10-19.

17. Ritchey FJ, Pinkston D, Goldbaum JE, Heerten ME. Perceptual correlates of physician referral to physical therapisst: Implications for role expansion. Soc Sci \& Med 1989;28:69-80.

18. Higgs J. Titchen A. Research and knowledge. Physiotherapy 1998;84:72-80.

19. Beckerman H, Bouter LM, Heijden GJMG van der, Bie RA de, Koes BW. Efficacy of physiotherapy for musculoskeletal disorders: what can we learn from research? Brit J Gen Pract 1993:43:73-7. 
20. Newman DJ. Physiotherapy for best effect. Physiotherapy 1997:83:5-11.

21. Koes BW. Editorial - Now is the time for evidence based physiotherapy. Physiotherapy Research International 1997; 2:iv- $v$.

22. Hendriks HJM, Wagner C, Brandsma JW, Dekker J, Wams HWA, Oostendorp RAB. Consultatief Fysiotherapeutisch Onderzoek (CFO) in de eerste lijn. Introduktie van het CFO-project en informatie uit de literatuur. Ned Tijdschr Fysiother 1992;102:176-183.

23. Hendriks HJM, Wagner C, Brandsma JW, Oostendorp RAB, Dekker J. Experiences with physiotherapsist consultation. Results of a feasibility study. Physiother Theory Prac 1996;12(4):211-20.

24. Uunk WJG, Groenewegen PP, Dekker J. Verwijzingen van huisartsen naar fysiotherapeuten: een verklaring en analyse van verschillen tussen huisartsen. Mens en Maatschappij 1992;67(4):389-411.

25. Akpala CO, Curran AP, Simpson J. Physiotherapy in general practice: patterns of utilization. Public Health 1988:102:263-68.

26. Yoshida KK, Allison KR. Sociodemographic and health-related characteristics of Ontarians making contact with physical therapists: analysis of the 1990 Ontario health survey. Physiotherapy Canada 1997:49:214221 .

27. Wellman B. Lay Referral, Networks: using conventional Medicine \& Alternative Therapies for low back pain. Research in the Sociology of Health Care 1995;12:213-238.

28. Carey T, Garrett J, Jackman A, et al. The outcomes and costs of care for acute care low back pain among patients seen by primary care providers, chiropractors and orthopedic surgeons. N Engl J Med 1995;333:913-917.

29. Carey T, Evans A, Hadler N, et al. Acute severe low back pain: a population-based study of prevalence and care-secking. Spine 1996:21:339-344.

30. Mielenz TJ, Carey TS, Dyrek DA, et al. Physical therapy utilization by patients with acute low back pain. Phys Ther. 1997;77:1040-1051.

31. Moncur C. Perceptions of physical therapy competencies in rheumatology. Physical therapists versus rheumatologists. Physical Therapy 1987:67(3):331-39.

32. Hendriks HJM, Wagner C, Dekker J, Brandsma JW. Evaluatie van het consultatief fysiotherapeutisch onderzock in de eerste hijn. Resultaten van een veldexperiment. Utrecht: Nivel, 1994.

33. American Physical Therapy Association (APTA). Guide to physical therapist practice. Phys Ther. 1997:77:1163-1650.

34. Hendriks HJM, Bie de RA, Zee van der J. Consultation, between. General Practitioners and medical consultants. What do we know from the literature? (submitted).

35. Cook TD, Campbell DT. Quasi-experimentation. Design and analysis issues for field settings. Boston: Houghton, Mifflin Company, 1979.

36. Wilkin D, Smith A. Explaining variation in general practitioners, referrals to hospital. Family Practice 1987:4:160-69.

37. Nederlands Huisartsen Genootschap (NHG). De verwijsbrief naar de Tweede Lijn - standaard 001. Huisarts en Wetenschap 1988:32:102-05.

38. Koninklijk Nederlands Genootschap voor Fysiotherapie (KNGF). Richtlijnen voor de fysiotherapeutische verslaglegging. Amersfoort: KNGF, 1993.

39. Lamberts $\mathrm{H}$. Wood M. International Classification of Primary Care. Oxford: Oxford University Press, 1987.

40. World Health Organization (WHO). ICIDH, International Classification of Impairments, Disabilities, and Handicaps: a manual of classification relating to the consequences of disease. Geneva: WHO, 1980.

41. World Health. Organization (WHO). International Classification of Impairments, Activities and Participation: a manual of dimensions of disablement and functioning (ICIDH-2). Geneva: WHO, 1997.

42. Heerkens YF, Brandsma JW, Ravensberg CD, Proposal for adaptation of the International Classification of Impairments, Disabilities, and Handicaps from the perspective of five Dutch health professions. Zoetermeer, Dutch Classification and Terminology Committee for Health (WCC) - National Council for Public Health (NRV), 1993.

43. Heerkens YF, Brandsma JW. Lakerveld-Heyl K, Ravensberg van CD. Impairments and disabilities - The difference. Proposal' for Adjustment of the International Classification of Impairments, Disabilities, and Handicaps. Phys, Ther. 1994:74:430-442.

44. Hendriks HJM, Brandsma JW, Heerkens YF, Oostendorp RAB, Nelson RN. Intraobserver and interobserver reliability of assessments of impairments and disabilities. Physical Therapy 1997:77:1097. !106. 
45. Valk R van der, Dekker J. Boschman M. Basisgegevens extramurale fysiotherapie 1989-1992. Gegevens uit het project "Beleidsgericht Evaluatie- en Effectonderzoek Fysiotherapie (BEEF)". Utrecht: Nivel, 1995.

46. Dekker J, van Baar ME, Curfs EChr, Kerssens JJ. Diagnosis and treatment in physical therapy; an investigation of their relationship. Phys Ther. 1993;73:568-580.

47. Armstrong D, Briten N, Grace J. Measuring general practitioner referrals: patient, workload and list size effects. J R Coll Gen Pract 1988:38:494-97.

48. Rasbach J. Woodhouse G. MLA Command reference, London: Institute of Education, University of London, 1995.

49. Bryk AS, Raudenbusch SW. Hierarchical Linear Models: applications and data management methods. Newbury Park: Sage publications, 1992.

50. Goldstein H. Multilevel statistical models. New York: Halsted Press ( $2^{\sim}$ edition), 1995.

51. Kerssens JJ, Sluijs WM, Verhaak PFM, Knibbe HJ, Hermans IMJ. Back care instructions in physical therapy: a. trend analysis of individualized back care programs. Phys Ther. 1999;79:286-295.

52. Pool JB, Hingstman L. Cijfers uit de registratie van beroepen in de eerstelijnsgezondheidszorg. Statistische gegevens per 1 januari. 1991 over huisartsen en verloskundigen. Utrecht: Nivel, 1992.

53. Pool JB. Hingstman L. Cijfers uit de registratie van beroepen in de eerstelijns-gezondheidszorg 1991. Statistische gegevens per 1 januari 1991 over in de eerste lijn werkzame fysiotherapeuten Utrecht: Nivel, 1993.

54. Hendriks HJM, Kerssens JJ, Elvers JWH, Dekker J, van der Zee J, Oostendorp RAB. Patterns of utilizarion and efficiency of care following a one-time physiotherapist's consultation in general practice. Physiotherapy Theory and Prac (accepted).

55. Prescot-Clarke P, Brooks T, Machray C. Focus on health care: surveying the public in four health care districts. London: Royal institute of Public administration and Social and Community Planning Research. 1988.

56. Hays RD, Ware JE. My medical care is better than yours: social desirability and patient satisfaction ratings. Med Care 1986; 24(6): 519-524.

57. Visser AP. Education in the hospital: differences in satisfaction, cognition, and emotional status between younger and older patients. Tijdschr Gerontol Geriatr 1988;19(3):113-119.

58. Wijkel D. Lower referral rates for integrated health centres in The Netherlands. Health Policy 1986:6:18598.

59. Stokx LJ, Gloerich ABM, Kersten TJJMT. Kostenbesparing door kwaliteitsbevordering. Utrecht: Nivel, 1992.

60. Stokx L, Bakker DH de, Delnoy DMJ, Gloerich ABM, Groenewegen PP. Verwijscijfers belicht. Utrecht: Nivel, 1992.

61. Oostendorp RAB, van Ravensberg CD, Wams HWA, Heerkens YF, Hendriks HJM. Fysiotherapic, wat omvat het? Bijblijven 1996;12:5-17.

62. Hendriks HJM, Bekkering GE, Brandsma JW, et al. Development and implementation of national practice guidelines: a prospect for continuous quality improvernent in physiotherapy. An introduction to the method of guideline development (Part I). Physiotherapy 2000;86;535-547.

63. May B. Dennis JK. Expert decision making in physical therapy. A survey of practitioners. Physical Therapy 1991;71:190-202.

64. Sahrmann SA. Diagnosis and classification by physical therapist: a special communication. Physical Therapy 1988;66:1703-06.

65. Verbrugge L.M. Jette AM. The disablement process. Soc Sci Med 1994:38:1-14.

66. Jette AM. Physical disablement concepts for physical therapy research and practice. Phys Ther. 1994; 74:380-386.

67. Jette D, Manago D, Medved E, et al. The disablement process in patients with pulmonary disease. Phys Ther. 1997:77:385-394.

68. Cott CA, Finch E, Gasner D, Thomas SG, Verrier MC. The movement continuum theory of physical therapy. Physiother Canada 1995:47:87-95.

69. Johnston M. Modeis of disability. Physiother Theory Prac. 1996;12:1311-[41.

70. Sahrmann SA. Moving precisely? Or taking the path of least resistance? Phys Ther. 1998;78:1208-1218. 


\section{Patterns of Utilization and Efficiency of Care following Physiotherapist's Consultation in General Practice}

\section{Abstract}

The purpose of this study was to investigate the impact of a one-time physiotherapist's consultation by general practitioners (GPs) on the utilization of physiotherapy services, functional outcome and number of treatment sessions per treatment episode.

A 7-month observational study with 59 pairs of randomly selected physiotherapists and GPs was conducted. Data were collected at the level of the GP, the physiotherapist, and the patient referred for a one-time physiotherapist's consultation, with a follow-up of patients being treated by physiotherapists after the consultation. Self-administered questionnaires (completed at the onset and completion of the study by physiotherapists), consultation requests, and standardized forms were used to obtain data. Concurrent outcome data were provided from national data collected on patients referred by GPs for physiotherapy treatment. The main variables measured were: (1) the characteristics of patients who received physiotherapy treatment after a one-time physiotherapist's consultation compared with those who were referred to medical specialists or treated by the GP themselve; (2) the predicted number of sessions per treatment episode related to the actual number; and (3) the functional outcomes of physiotherapy treatment.

The study sample consisted of 352 patients referred for a one-time physiotherapist's consultation by 53 out of 59 GPs. Physiotherapists participating in the study treated 224 patients after the consultation. Patterns of referral for physiotherapy treatment after consultation were positively related to increased age of the patients, lower levels of education, longer duration of the complaints, and a decrease in physical functioning measured in terms (and number) of impairments and disabilities. Functional outcomes were comparable to national reference data on patients referred by GPs for physiotherapy. The mean number of sessions per treatment episode, including a one-time consultation, was significantly lower when compared with the national reference data.

The findings indicate that a one-time physiotherapist's consultation improves appropriate referral and utilization of physiotherapy services.

\section{Based on:}

Hendriks HJM, Kerssens JJ. Elvers JWH. Dekker J, van der Zee J, Oostendorp RAB.

Patterns of utilization and efficiency of care following a one-time physiotherapist Consultation in General Practice.

Physiotherapy Theory and Practice (accepted) 


\section{Introduction}

The rising costs of physiotherapy services in The Netherlands occasioned the examination of utilization patterns, patient satisfaction, and outcome data of physiotherapy treatment. Outcome research in physiotherapy is needed to determine its effectiveness, to develop efficient treatment strategies, and to satisfy patient needs. ${ }^{1,2}$ Cost containment in the health care sector highlights the role of primary care physicians in The Netherlands, often called general practitioners (GPs), as care managers and gatekeepers to various health care services. ${ }^{3,4}$ Within the Dutch health care system, physiotherapy is only accessible after referral for treatment by a physician. Since $80 \%$ of the patients treated by physiotherapists are referred by GPs, physiotherapists function as important collaborating partners $^{6-8}$ This is particularly true for patients with disorders and complaints of the locomotor system..$^{6.79-12}$

Barriers preventing optimal collaboration between GPs and physiotherapists include poor communication, ${ }^{13-18}$ doubt about the effectiveness of or indications for physiotherapy treatment, ${ }^{19-21}$ and lack of knowledge about a changing -- research-based -- physiotherapy practice. $^{20-23}$ These problems can, to a large extent, be dealt with when GPs and physiotherapists increase cooperation by regular and efficient communication with each other ${ }^{15-17,24}$ It is suggested that physicians'current level of usage of conservative services (e.g. physiotherapy) may be suboptimal with patients with long-term functional problems and an established need for preventive therapy. ${ }^{25.26}$ There are also claims that physiotherapy services are underutilized because physicians often fail to recognize patients' functional needs, lack familiarity with physiotherapists' skills, and lack structured collaboration with physiotherapists. ${ }^{16,17,24,27,28}$

Providing the GP with an opportunity for a one-time physiotherapist's consultation referral before he or she decides whether to refer for further physiotherapy treatment or more expensive diagnostic evaluation or therapy by medical specialists may be recommended. ${ }^{16}$, ${ }^{17.25,26}$ If a GP is uncertain about the appropriateness of referral, or lacks insight into the effectiveness of physiotherapy or treatment options, the consultation can provide the GP information in order to decide on an efficient (and transparent) management plan.

To our knowledge, no studies have been published on the impact of a one-time physiotherapist's consultation on utilization of physiotherapy services, number of treatment sessions, and functional outcome ${ }^{6.24,29} \mathrm{~A}$ one-time physiotherapist's consultation could either increase or decrease the utilization of physiotherapy services. However, should the GP decide, after a physiotherapist's consultation, to refer the patient for treatment, the treatment objectives and strategy will at that time be known, transparent and explicitly communicated by a written report by the physiotherapist.

It should be noted that, pertinent to existing uncertainties about the appropriateness of physiotherapy treatment and the capability of physiotherapists to predict or estimate the 
maximum achievable functional outcome or effectiveness of physiotherapy treatment, a one-time physiotherapist's consultation could also result in unnecessary referrals and overutilization of physiotherapy services.

Health service utilization literature regarding physiotherapy suggests that patients' sociodemographic and health status related variables may indicate the utilization of physiotherapy services ${ }^{6.30-39}$ and the number of sessions (thus the cost) of one episode of physiotherapy treatment. ${ }^{6.25 .36,40.47}$ In the first report on the effects of a one-time physiotherapist's consultation from the perspective of the GP, it was stated that GPs were satisfied with the outcome and process of consultation, and that most GPs (93\%) agreed with the recommendations of the physiotherapist, which resulted in $50 \%$ of the cases being managed in a different manner than was intended before the physiotherapist's consultation. $^{48}$

To determine the extent to which physiotherapy services can be utilized and efficiently provided, data collected in a prospective follow-up study of patients being treated by physiotherapists after a one-time physiotherapist's consultation were analysed. The purpose of this study was to investigate the impact of a one-time physiotherapist's consultation on the utilization of physiotherapy services, functional outcome, and number of sessions per treatment episode.

To understand the role of one-time physiotherapist's consultation, and their service utilization related to functional outcome and the limited number of sessions allowed per treatment episode, this research focused on five key questions:

1. What are the GP's courses of action (referral patterns) following a one-time physiotherapist's consultation?

2. Do patient characteristics in those who are treated by physiotherapists following a one-time consultation differ from those who are treated by medical specialists or by the GPs themselves?

3. How many sessions per treatment episode are required?

- How many treatment sessions were expected for patients who, after a one-time consultation, were or had been referred for physiotherapy treatment?

- Is the consulting physiotherapist's prognosis of the number of sessions in accordance with the actual number of sessions per treatment episode?

- Additionally, is the actual number of treatment sessions of patients treated by physiotherapists following consultation different from the treatment records catalogued in the national reference database of patients referred by GPs for physiotherapy treatment?

4. What is the functional outcome of physiotherapy treatment?

- Additionally, is the functional outcome of patients treated by physiotherapists following consultation different from functional outcome data. catalogued in the national reference database of patients referred by GPs for physiotherapy treatment?

5. What is the opinion of the physiotherapist regarding the process of a one-time consultation and the opportunity for the GP to refer for a one-time consultation? 


\section{Methods}

\section{Observational study}

A group of patients referred by GPs for a one-time physiotherapist's consultation was studied, and the number of sessions per treatment episode of patients being treated by a physiotherapist after the consultation was recorded. For the purpose of this study, one physiotherapist was paired with one GP, stratified for degree of urbanization (i.e. rural, semi-urbanized, or urban), since GP referral patterns tend to be related to the geographical location of both GPs and patients ${ }^{49} \mathrm{~A}$ random sample of 72 physiotherapists, working in different practices in primary care, was drawn from the total PT population as listed in the (Nivel) national database, in four different regions of The Netherlands $(n=1533)$. The GP was randomly selected from a list of GPs who had a regular referral relationship with the participating physiotherapist. If a selected GP did not agree to participate, another GP was randomly selected from that list. The participating physiotherapists were trained in the process of a one-time consultation, the use of standardized patient registration and communication forms, including operational definitions, and the data collection procedures. ${ }^{16.17}$

\section{Sample of participants}

The willingness to participate in the study for physiotherapists and GPs was $86 \%$ and $74 \%$, respectively. Of the 62 GP-physiotherapist pairs originally created, 59 completed the study, due to 3 GPs withdrawing from the study for personal reasons. Six GPs did not use a single consultation request. The GPs had a mean age of 43.5 years $(s d=7.0)$. The majority of them were male ( $92 \%)$. The mean number of registered patients per GP was 2316 (range 250-3150), and nearly half the GPs worked single-handed. A small number of GPs had recently completed their training, while $60 \%$ had more than 10 years of experience in primary care. Comparison of the data of $53 \mathrm{GPs}$, representing a population of 124,245 patients with all GPs in primary care $(n=6,548)$, shows that the GPs are representative for gender, age, years of establishment in general practice, personal list size and number of professional partners. ${ }^{16}$

The physiotherapists had a mean age of 36.7 years $(s d=6.1)$. The majority of the physiotherapists $(66 \%)$ were male and had wide working experience in terms of years of establishment ( $59 \%$ longer than 10 years). Comparing the data of the selected therapists with the data of all physiotherapisis working in primary health care $(n=10,187)$ shows a good representation in terms of gender, age, and type of post-graduate courses or specialties. The acknowledged specialties of the 53 physiotherapists (by the Royal Dutch Physiotherapy Association) were: 15 manual therapists, 15 sports physiotherapists, six pediatric physiotherapists, and 5 trained therapists in womens' health problems. The distribution of the private practices of participating physiotherapists showed an underrepresentation of single-handed practices ( $11 \%$ vs $35 \%$ ), an over-representation of group practices (more than one partner: $81 \%$ vs $44 \%$ ) and a greater than average working 
experience in primary care. Thirty-nine physiotherapists $(74 \%)$ were sufficiently $(28 / 53)$ or very $(11 / 53)$ satisfied about their cooperation with their matched GP. ${ }^{16}$

\section{Process of consultation}

The process of a one-time physiotherapist's consultation by written communication was as follows: (1) The GP is undecided as to the possible benefit of physiotherapy. (2) The GP decides to consult the physiotherapist. (3) The GP communicates the reason for the request for consultation and the patient's clinical status to the physiotherapist. (4) The physiotherapist evaluates the patient's condition and functional status. (5) The physiotherapist communicates the findings and treatment recommendations in a written document presented to the GP. (6) The GP evaluates the additional physiotherapy information and the recommendations of the physiotherapist, and decides on the preferred patient management.

No attempt was made to influence the GPs' management decisions. All patients received information about the purpose and procedures of the study.

\section{Data collection}

Background information about the physiotherapists was collected from questionnaires which the physiotherapists completed at the onset of the study and at the conclusion of the study. The baseline questionnaire provided data on the physiotherapists' practice, and personal and professional experience. In addition, the frequency of the physiotherapists' patient communication with their matched GP was quantified as once or less than once per month versus more than once per month, and their perception about the cooperation was measured on a five-point Likert scale (excellent [1] - poor [5]). At the conclusion of the study, questionnaires were given to physiotherapists for responses relevant to the appropriateness and practicality of the one-time physiotherapist's consultation and the standard forms.

Patient characteristics were collected during the process of consultation by both GPs and physiotherapists using standard forms. ${ }^{17}$ Upon referral for a one-time consultation, the physiotherapist registered the patient's personal and sociodemographic data, and analyzed the patient's functional status in terms of impairments and disabilities. ${ }^{50-52}$ The physiotherapist assessed whether an impairment or disability was "present" and indicated its severity on a three-point Likert scale. A standard form was designed as a generic tool for assessing physical functioning and listed 36 impairments and 27 disabilities (see Appendix). ${ }^{53}$

The physiotherapist's report form was used to document clinical findings and functional status, conclusions and recommendations. In the report form from the physiotherapist, the expected number of treatment sessions, the duration of a treatment episode, and the expected functional outcome where the physiotherapist thought there was a need for physiotherapy treatment, were also stated. The functional outcorne was measured in terms of impairments and disabilities according to the International Classification of Impairments, Disabilities, and Handicaps (ICIDH). ${ }^{50-52}$ 
Table 1. Comparison of the number of patients treated by general practitioners (GP), medical specialists (MS) or physiotherapists (PT) before (fictitious policy) and after (actual policy) a one-time physiotherapist's consultation

\begin{tabular}{|c|c|c|c|c|c|c|}
\hline & & \multicolumn{4}{|c|}{$\begin{array}{l}\text { No. of patients by care provider before a one- } \\
\text { time consultation }\end{array}$} & \multirow[b]{2}{*}{ Total } \\
\hline & & GP & MS & PT & Other & \\
\hline \multirow{5}{*}{$\begin{array}{l}\text { No. of patients by care } \\
\text { provider after a one-time } \\
\text { consultation }\end{array}$} & $\mathrm{GP}$ & 10 & 12 & 18 & - & 40 \\
\hline & MS & 9 & 20 & 24 & 0 & $53^{*}$ \\
\hline & PT & 19 & 67 & 133 & 5 & $224^{*}$ \\
\hline & Other & - & 2 & 4 & - & 6 \\
\hline & Total & 38 & 101 & 179 & 5 & 323 \\
\hline
\end{tabular}

- Significant difference in number of referrals before and after a one-time physiotherapist's consultation (increase in number of patients treated by physiotherapists: $p=0.019$; decrease in number of patients treated by medical specialists: $p<0.001$

In a reliability study, the interobserver reliability of these items was found to be sufficiently high. ${ }^{53}$ The medical diagnosis, referral data and types of complaints were classified according to the International Classification of Primary Care (ICPC) ${ }^{54}$ For this purpose, a registration form was developed based on the guidelines for documentation of the Royal Dutch Physiotherapy Association (KNGF). ${ }^{55}$ If the GP decided to refer for physiotherapy treatment following consultation, the physiotherapist collected treatment data and provided information on a standard registration form at each patient's discharge, of the total number of sessions given and functional outcome on the impairment and disability level as measured on a five-point Likert scale (completely recovered [1]; substantial improvement [2]; stabilized [3]; deteriorated [4]; vastly worsened [5]). A treatment episode was defined as all therapy sessions provided between the initial and discharge session.

At the completion of the treatment period, the patients reported their global assessment of the effect of physiotherapy treatment measured on a five point-Likert scale (completely recovered [1] - vastly worsened [5]).

To evaluate the impact of a one-time physiotherapist's consultation on the number of treatment sessions and functional outcome, data from this study were compared with concurrent data of 17,201 patients included in the national database. ${ }^{10.11}$

\section{Data Analysis}

Descriptive statistics were used to: (1) compare the demographic and health status-related characteristics of patients who were being treated by a physiotherapist, with those patients who were being treated by a GP or medical specialist respectively, after a one-time consultation; (2) compare the predicted and actual number of sessions per treatment 
episode of patients who were being treated by physiotherapists after the consultation; (3) compare the actual number of sessions after a one-time consultation, with national reference data of patients who were directly referred for physiotherapy treatment $(\mathrm{n}=17.201))^{10,11}$ and (4) describe the opinion of the physiotherapist regarding the process of a one-time consultation.

Data on treatment goals and number of sessions were aggregated on the level of treatment episodes. All data were entered into SPSS-X (Release 4.1. Chicago, III: SPSS Inc; 1991) for analysis. Standard statistical methods were used and included a chi-square test for independent proportions and categorical data and Student's t-tests or ANOVA for comparison of group means (non-parametric analysis was used to confirm t-test or ANOVA results). Testing was in all cases two-sided. The level of statistical significance for all tests was set at $\mathrm{p}<0.05$.

\section{Results}

\section{Sample of patients}

352 patients were referred for a one-time physiotherapist's consultation over an enrollment period of 7 months. Although none of the patients refused the physiotherapist's consultation, 10 patients preferred to see a physiotherapist of their own choice rather than one of the therapists participating in the study. In the follow-up of 342 patients referred for a one-time consultation, 243 patients were indicated for physiotherapy treatment. Nineteen of 243 patients $(5.6 \%)$ were lost to follow up because they were being treated by a physiotherapist not participating in the study as recommended by the physiotherapistconsultant. Therefore, data from 323 patients initially referred for a one-time consultation and a sample of 224 patients being treated by physiotherapists after the consultation are included in this analysis. All patients signed the informed consent form.

\section{Referral pattern following consultation}

A four-by-four table (Table 1) was generated to compare the before-and-after referral direction. Table 1 compares the number of patient referrals that the GP would have referred for physiotherapy treatment if the physiotherapist had not been consulted, with the actual number of patients being treated by physiotherapists after a one-time. consultation. Physiotherapist's consultation resulted in more patient referrals for physiotherapy treatment ( 179 vs $224: p=0.018$ ) and in less referrals to medical specialists (101 vs 53: $p=0.001$ ). The number of patients treated by other health professionals ( $5 \mathrm{vs}$ 6) or by the GPs themselves ( 38 vs 40 ) were not changed substantially as indicated in the marginal totais of the table. Caution should be exercised in interpreting these changes in referral pattern since the changes are more complex than the marginal totals of the table indicate. 
Table 2. Comparison of demographic and health-status-related characteristics between the three groups (and pair-wise) of patients treated by physiotherapists, general practitioners or medical specialists afier a one-time physiotherapist's consultation: \%. (No.) unless otherwise stated

\begin{tabular}{|c|c|c|c|c|c|c|c|c|c|c|c|}
\hline & & $\begin{array}{l}\text { physio- } \\
\text { therapist } \\
(n=224)\end{array}$ & & $\begin{array}{r}\text { gener } \\
\text { practition } \\
(\mathrm{n}=4 \mathrm{C}\end{array}$ & & & $\begin{array}{r}\text { medic } \\
\text { special } \\
(\mathrm{n}=5\end{array}$ & & $(\mathrm{n}=$ & & \\
\hline & $\%$ & (No.) & $\%$ & (No.) & & $\%$ & (No.) & & $\%$ & (No.) & P-value \\
\hline \multicolumn{12}{|l|}{ Demographic } \\
\hline Gender (male) & 46 & (106) & 33 & (13); & & 57 & (30) & * & 46 & (147) & 0.07 \\
\hline Mean (sd) age (yr) & 38.2 & $(15.4)$ & 30.1 & $(12.8)^{\mathrm{s}}$ & & 37.3 & (15.8) & & 37.1 & (16.9) & $0.03^{4 s}$ \\
\hline Insurance (private) & 25 & (57) & 20 & (8) & & 36 & (19) & $*$ & 27 & (84) & 0.18 \\
\hline Education & & & & & $*$ & & & & & & 0.00 \\
\hline low & 46 & (104) & 23 & (9) & & 43 & (23) & & 43 & (136) & \\
\hline middle & 42 & (94) & 47 & (19) & & 45 & (24) & & 43 & (137) & \\
\hline high & 12 & (26) & 30 & (12) & & 11 & (6) & & 14 & (44) & \\
\hline Employed (yes) & 50 & (1113) & 53 & (21) & & 53 & (28) & & $5 !$ & (162) & 0.88 \\
\hline $\begin{array}{l}\text { Marital status } \\
\text { (single) }\end{array}$ & 9 & (20) & 8 & (3) & & 13 & (7) & & 10 & (30) & 0.61 \\
\hline \multicolumn{12}{|c|}{ Health status related characteristics } \\
\hline Duration complaint & & & & & * & & & & & & 0.00 \\
\hline$<1$ wk & 3 & (7) & 15 & (6) & & 8 & (4) & & 5 & (17) & \\
\hline 1 wk - 12 wks & 39 & (87) & 60 & (24) & & 36 & (19) & & $4 !$. & (130) & \\
\hline 13 wks - 1 year & 28 & (63) & 13 & (5) & & 28 & (15) & & 26 & (83) & \\
\hline$>1$ year & 30 & (67) & 13 & (5) & & 28 & (15) & & 27 & (87) & \\
\hline $\begin{array}{l}\text { Psychosocial } \\
\text { problems }\end{array}$ & 25 & (56) & 10 & (4) & - & 25 & (13) & & 23 & (73) & 0.14 \\
\hline Prior physiotherapy * & 24 & (54) & 10 & (4) & * & 11 & (6) & & 20 & (64) & 0.05 \\
\hline \multicolumn{12}{|c|}{ Prior medical interventions * } \\
\hline Diagnosis & 42 & (93) & 25 & (10) & * & 34 & (18) & & 38 & (121) & 0.18 \\
\hline Therapy & 22 & (50) & 19 & (4) & & 25 & (13) & & 21 & (67) & 0.19 \\
\hline \multicolumn{12}{|l|}{ Affected organ/tissue" } \\
\hline Bone & 25 & (56) & 18 & (7) & & 19 & (10) & & 23 & (73) & 0.54 \\
\hline Joint & 81 & $(181)$ & 56 & (23) & * & 71 & (38) & & 76 & (242) & 0.01 \\
\hline Muscle & 71 & (154) & 55 & (22) & * & 70 & (37) & & 69 & (218) & 0.21 \\
\hline Nerve & 13 & (29) & 15 & (6) & & 30 & (16) & * & 16 & (51) & 0.60 \\
\hline \multicolumn{12}{|c|}{ Type of disorder in terms of ICPC } \\
\hline Back (L.02) & 19 & $(43)$ & 18 & (7) & & 15 & (8) & & 18 & (58) & 0.81 \\
\hline Knee (L.15) & 17 & (39) & 20 & (8) & & 19 & (10) & & 18 & (57) & 0.84 \\
\hline Shoulder (L08) & 8 & (18) & 20 & (4) & & 9 & (5) & & 9 & (27) & 0.84 \\
\hline Neck (L04) & 7 & (16) & 5 & (2) & & 8 & (4) & & 7 & (22) & 0.88 \\
\hline
\end{tabular}

For the same complaint

More than one option was possible

International Classification of Primary Care (ICPC) s"

P-values of differences using Chi-square test or Anova th between the three treatment groups

- Significant differences (pair-wise comparison) using Chi-square * or Student's t-test" berween two groups: (I) patients treated by physiotherapists compared with those treated by GPs, and (2) patients treated by physiotherapists compared with those ireated by medical specialists $(p<0.05)$ 
Table 1 shows that of the 179 patients $(74 \%)$ that would have been referred to a physiotherapist, 133 were referred for physiotherapy treatment. In 46 of those 179 patients $(26 \%)$, the initial referral decision for physiotherapy treatment was changed after the consultation. The initial management decision to refer to a medical specialist or to treat the patient by themselves was changed in 81 of $101(80 \%)$ and 28 of 38 patients $(74 \%)$. respectively. Overall, the intended treatment policy was changed in $50 \%(163 / 323)$ of the patients.

\section{Demographic and health status related characteristics}

The patients' baseline demographic and health-status-related characteristics associated with utilization of physiotherapy compared with those treated by a GP or medical specialist are presented in Table 2. A study of the proportions in the demographic and health-statusrelated variables, for each treatment group, suggests differences between the three groups in 6 of the 12 measured variables: age, level of education, duration of the complaint, previous physiotherapy, and affected joint or nerve-tissue.Comparisons of proportions of patients being treated by physiotherapists with those treated by the GP or medical specialist suggest that profiles of patients being treated by physiotherapists and medical specialists showed the most similarity. Patients being treated by medical specialists differed in gender, health insurance and affected nerve-tissue. The differences between groups of patients treated by physiotherapists and those treated by GPs were located in 8 out of 12 variables. Patients differed in age (mean $=38.2$ years $[s d=15.4$ ] compared with 30.1 years $[\mathrm{sd}=12.8]$ ) respectively, and more patients treated by physiotherapists had a low level of education, long-term conditions, and psychosocial problems, and more often had received previous physiotherapy and medical diagnostic interventions for the same complaint in the past 12 months. The specific body parts/tissues indicating utilization of physiotherapy were problems of the joint(s) and muscle(s).

Differences among groups in prevalence of impairments and disabilities are reporied in Table 3. Eighteen of the 36 impairments had a prevalence of 10 percent or more, and were included for further analysis. Overall analysis showed that there were significant differences in 7 of the 18 impairments among groups. Patients treated by physiotherapists compared with those treated by GPs were different in 7 out of 18 impairments and in the mean number of impairments. Patients treated by physiotherapists more frequently had pain following movement, impaired pain sensation, pain behavior, decreased range of motion and muscle strength, impairments in body posture and joint position. The mean number (sd) of impairments in patients sent for physiotherapy was $7.5(\mathrm{sd}=3.2)$ versus $5.3(\mathrm{sd}=2.6)$ of those treated by the GPs $(\mathrm{p}=0.001)$ Patients treated by physiotherapists compared with those treated by medical specialists differed in the impairments of tiredness and sensibility. 
Table 3. Significant differences in prevalence of physical functioning in terms of impairments and disabilities among the three groups of patients ireated by physiotherapists, general practitioners or medical specialists after a one-time physiotherapist's consultation: \% (No.) unless otherwise stated

\begin{tabular}{|c|c|c|c|c|c|c|c|c|c|c|}
\hline & \multicolumn{2}{|c|}{$\begin{array}{l}\text { physio- } \\
\text { therapist } \\
(\mathrm{n}=224)\end{array}$} & \multicolumn{3}{|c|}{$\begin{array}{r}\text { general } \\
\text { practitioner } \\
(\mathrm{n}=40)\end{array}$} & \multicolumn{2}{|c|}{$\begin{array}{r}\text { medical } \\
\text { specialist } \\
(n=53)\end{array}$} & \multicolumn{3}{|c|}{$\begin{array}{l}\text { Total } \\
(n=317)\end{array}$} \\
\hline & $\%$ & (No.) & $\%$ & (No.) & & $\%$ & (No.) & $\%$ & (No.) & $\mathrm{P}$-value ${ }^{b}$ \\
\hline \multicolumn{11}{|l|}{ Impairments ${ }^{a}$} \\
\hline Pain following movement & 80 & (179) & 60 & (24) & - & 76 & $(40)$ & 77 & (243) & 0.04 \\
\hline Pain sensation & 36 & $(81)$ & 23 & (9) & * & 32 & (17) & 34 & $(107)$ & 0.24 \\
\hline Pain behavior & 34 & (76) & 18 & (7) & * & 19 & $(10)$ & 29 & (93) & 0.04 \\
\hline Decreased range of motion & 63 & (141) & 35 & (14) & * & 64 & (34) & 59 & (189) & 0.00 \\
\hline Muscle strength & 42 & (95) & 15 & (6) & - & 45 & (24) & 39 & (125) & 0.00 \\
\hline Body posture & 44 & (98) & 23 & (9) & - & 32 & (17) & 39 & (124) & 0.04 \\
\hline Joint position & 38 & (84) & 20 & (8) & $*$ & 32 & (17) & 34 & (109) & 0.14 \\
\hline Sensibility & 11 & (25) & 10 & (4) & & 30 & $(16)^{*}$ & 14 & (45) & 0.00 \\
\hline Tiredness & 15 & (33) & 10 & (4) & & 28 & $(15)^{*}$ & I6, & $(52)$ & 0.02 \\
\hline $\begin{array}{l}\text { Mean number (sd) of } \\
\text { impairments }\end{array}$ & 7.5 & (3.2) & 5.3 & $(2.6)^{5}$ & & 7.8 & (3.8) & 7.4 & (3.3) & $0.00^{\mathrm{sen}}$ \\
\hline \multicolumn{11}{|l|}{ Disabilities in complex skills" } \\
\hline Domestic activities & 32 & $(72)$ & 15 & (6) & - & 34 & (18) & 30. & (96) & 0.09 \\
\hline Related to work & 52 & (117) & 35 & (14) & * & 47 & (25) & 49 & (156) & 0.21 \\
\hline Related to recreation & 60 & (134) & 32 & (13) & * & 55 & (29) & 55 & (176) & 0.01 \\
\hline $\begin{array}{l}\text { Mean number (sd) of } \\
\text { disabilities }\end{array}$ & 5.7 & $(4.0)$ & 4.6 & (4.6) & & 5.8 & (4.8) & 5.7 & $(4.2)$ & $0.38^{\wedge a}$ \\
\hline
\end{tabular}

" In total 18 impairments and 17 disabilities were included based on a prevalence of more than 10 percent. liems are listed on a standard registrarion form ${ }^{3}$ based on the International Classificarion of Impairments, Disabilities, and Handicaps (ICIDH) ${ }^{\text {sos. }}$ (see also appendix)

- P-values of differences using Chi-square test or Anova ${ }^{\text {An }}$ between treatment groups.

* Significant differences (pair-wise comparison) using Chi-square * or Students t-test ${ }^{\circ}$ between two groups: (1) patients treated by physiotherapists compared with those treated by GPs, and (2) patients treated by physiotherapists compared with those treated by medical specialists $(p<0.05)$ 
Table 4. Comparison in categories and mean number (sd) of treatment sessions of patients referred for treatment following a one-time consultation with patients referred for physiotherapy treatment as listed in the national data base

\begin{tabular}{|c|c|c|c|c|}
\hline \multirow[b]{2}{*}{ Treatment sessions* } & \multicolumn{2}{|c|}{$\begin{array}{l}\text { No, of patients ( } \%) \text { treated } \\
\text { by a physiotherapist following } \\
\text { a one-time consultation }(n=224)\end{array}$} & \multicolumn{2}{|c|}{$\begin{array}{l}\text { No. of patients }(\%) \text { treated by } \\
\text { a physiotherapist following direct } \\
\text { referral by GPs for treatment }(n=17,201)\end{array}$} \\
\hline & No. (\%) & cum. $\%$ & No, $(\%)$ & cum. $\%$ \\
\hline$\leq 6$ & $60(27 \%)$ & $27 \%$ & $4,713(27 \%)$ & $27 \%$ \\
\hline 7.9 & $58(26 \%)$ & $53 \%$ & $2,924(17 \%)$ & $44 \%$ \\
\hline $10-12$ & $47(21 \%)$ & $74 \%$ & $4,472(26 \%)$ & $70 \%$ \\
\hline 13-18 & $21(9 \%)$ & $83 \%$ & $2.234(13 \%)$ & $83 \%$ \\
\hline$\geq 19$ & $38(17 \%)$ & $100 \%$ & $2,876(17 \%)$ & $100 \%$ \\
\hline Mean (sd)" & $11.6(7.8)$ & & $13.0(11.0)$ & \\
\hline
\end{tabular}

On the level of disabilities, 17 of the 27 disabilities had a prevalence of 10 percent or more. The overall analysis showed that "disability in recreation" was significantly different among the groups. Patients treated by a physiotherapist compared with those treated by a GP more often had disabilities in complex skills: disabilities in domestic activities, in work-related activities, and in recreation. There were no significant differences among groups in the elementary (sensory motor) disabilities and disabilities in locomotion (see Appendix) classifications.

\section{Number of treatment sessions following consultation compared with national data}

Table 4 shows that $27 \%$ of the patients $(60 / 224)$ were treated in 6 treatment sessions or less, $53 \%$ of the patients $(118 / 224)$ were treated in 9 or less, and $74 \%$ of the patients $(165 / 224)$ were treated in 12 or less treatment sessions. In $17 \%(38 / 224)$ of the patients, the physiotherapists needed more than 18 sessions per treatment episode (range $=3-31$ ). These proportions were different when compared with the national reference group $\left(p=0.04 ; X^{2}=17.15 ; \mathrm{df}=4\right)$ of patients referred by their $\mathrm{GP}$ for physiotherapy treatment. The mean number of treatment sessions (sd), including the one-time consultation, was $11.5(\mathrm{sd}=7.6)$ and was significantly lower $(p=0.03)$ when compared with the reference group (mean $=13 ; \mathrm{sd}=11$ ). The average length of the treatment episode was 7.3 weeks $(s d=6.4)$ and was significantly shorter $(p=0.01)$ when compared with the reference group." 
Table 5. Comparison of the expected and actual number of treatment sessions in four categories

\begin{tabular}{|c|c|c|c|c|c|c|}
\hline & & \multicolumn{4}{|c|}{ Actual number of treatment sessions } & \multirow[b]{2}{*}{ Total } \\
\hline & & $\leq 6$ & $7-12$ & $13-18$ & $\geq 19$ & \\
\hline \multirow{5}{*}{$\begin{array}{l}\text { Expected number of } \\
\text { treatment session }\end{array}$} & $\leq 6$ & 29 & 20 & 1 & 0 & 50 \\
\hline & $7-12$ & 26 & 66 & 13 & 25 & 130 \\
\hline & $13-18$ & 3 & 17 & 5 & 6 & 31 \\
\hline & $\geq 19$ & 2 & 3 & 0 & 6 & 11 \\
\hline & Total & 60 & 106 & 19 & 37 & $222^{\circ}$ \\
\hline
\end{tabular}

- Two patients were excluded because the physiotherapists found their condition very unstable or unpredictable

\section{Expected and actual number of treatment sessions}

Table 5 compares the predicted number of treatment sessions with the actual number of physiotherapy treatment sessions following the consultation. In 2 patients the physiotherapists were not able to predict the number of treatment sessions needed because they found the condition of their patients very unstable or unpredictable and therefore these 2 patients were excluded from the analysis $(n=222$ patients). The percentage of agreement within categories of six treatment sessions was $48 \%(106 / 222)$. In $29 \%$ of the cases $(65 / 222)$ there was an overestimation whereas in $23 \%$ of the cases $(55 / 222)$ the expected number of treatment sessions was underestimated.

\section{Functional outcomes}

Table 6 presents the outcome of physical functioning at the level of impairments and disabilities as measured by the physiotherapist, and the patient's global assessment of the effect of physiotherapy treatment as experienced by the patient. The overall percentage of "substantial" or "complete" improvement in physical functioning was $84 \%$ on both the impairment and disability levels. The patient-rated assessment (global perceived effect) of substantial or complete improvement of their health problem was $78 \%$ versus $69 \%$ when compared with the national reference data $(p<0.05),{ }^{10.11}$

There were no differences in outcome on the level of physical functioning, patient's global assessment of effect, and mean number of treatments between subgroups of patients in which the intended referral for physiotherapy was changed $(n=93)$ or not $(n=133)$, after a one-time physiotherapist's consultation. 
Table 6. Outcome measures and differences between subgroups" of patients treated by a physiotherapist following a one-time physiotherapist's consultation

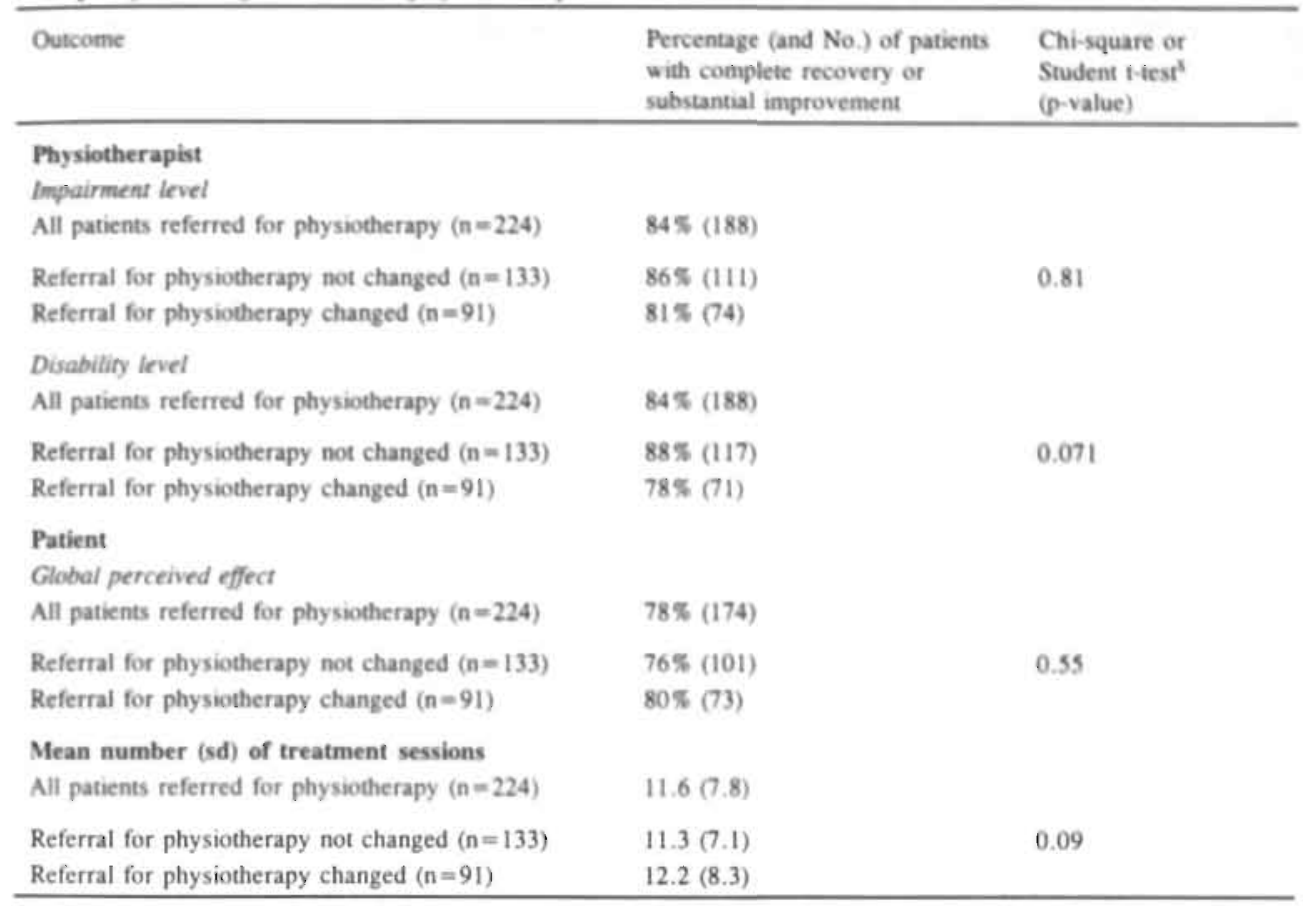

* Subgroups of patients being treated by a physiotherapist in which the intended referral for physiotherapy treatment was changed $(n=91)$ or not $(n=133)$ following a one-time physiotherapist's consultation

\section{Physiotherapists' opinions of the process of a one-time consultation}

Results from the questionnaire at the conclusion of the study indicated that 95 percent $(50 / 53)$ of the physiotherapists believed that the process of consultation could easily be incorporated into their daily practice. Twenty percent (10/53) of the physiotherapists indicated that scheduling was sometimes difficult within the requested time period. The physiotherapists were generally satisfied with the standard consultation request and report forms, as allowing the physiotherapist insight into the patient's health problem, GP's management policy, a clearly stated consuitation request, and structured written communication.

The average amount of time taken to complete the history and physical examination (including the research questions and use of standard forms) was 55 minutes (range $=50$ $70 \mathrm{~min}$ ). The time needed for writing the report was within a range of 10-30 minutes. All physiotherapists indicated that a one-time physiotherapist's consultation offered them an important communication tool for individually-tailored and joint patient care. 
All physiotherapists agreed that a one-time physiotherapist's consultation may also contribute to making the participating health care professionals aware of physiotherapists' specific expertise, the goals of physiotherapy treatment, and the scope and breadth of their profession.

\section{Comment}

The issue of cost containment continues to dominate the debate regarding strategies for organizing and financing health care services. ${ }^{3.4 .56,57}$ An issue of particular concern in this regard has been the increasing prevalence of disorders of the locomotor system, the continuing increase in patients' help-seeking behavior and an increase in the consumption of primary care services. ${ }^{26.58-61}$

A study of health care utilization in The Netherlands highlights the role of GPs today as gatekeepers, controlling the distribution of resources to the various health care providers (selection-influence). ${ }^{4.62}$ Although the literature on the utilization of health services is extensive, the literature focused on utilization of physiotherapy services is scarce ${ }^{6.16,25,31,39,45,46}$ This observational study, validated against national reference data for clinical outcome for patients referred by GPs for physiotherapy treatment ${ }^{10,11}$ shows the impact of a one-time physiotherapist's consultation on the utilization of physiotherapy services for a broad range of dicordere of the locomotor system. The study included 352 patients referred for a one-time physiotherapist's consultation by 53 GPs during a 7-month enrollment period, with a follow-up of 224 patients being treated by physiotherapists after the consultation. Additional information on its use and impact on referral patterns is reported elsewhere. ${ }^{48}$

One of the objectives was to identify patient characteristics related to utilization of physiotherapy ireatment. In our previous report, we found that characteristics of patients referred for a one-time physiotherapist's consultation differed from those in the with national database of patients referred by GPs for physiotherapy treatment. Although not reported in this paper, the characteristics of patients referred for physiotherapy treatment following a one-time consultation also differed from those in the national database of GP referrals for physiotherapy treatment. ${ }^{63}$

The findings of this study suggest that the probability of patients being treated by a physiotherapist increased with low education, long-term complaints, psychosocial problems, previous physiotherapy, and medical diagnostic testing for the same complaint in the past 12 months. Patients who had received physiotherapy previously were more likely to be treated by a physiotherapist than those who had not. One of the explanations for this may be that patients who had been previously treated by a physiotherapist were satisfied with their improvement or the recovery from their condition, and the care they had received. Furthermore, patients with a decrease in physical functioning, measured in terms and number of impairments and disabilities, and patients with a chronic condition 
(more than 13 weeks) were more likely to be treated by physiotherapists than by the GPs themselves. The findings also indicate that demographic and health-status-related characteristics are important predictors for the utilization of physical therapy services rather than the medical diagnosis alone.

These findings could have important implications when comparisons are made of the outcomes of different providers. Unequal baseline characteristics could lead to inappropriate conclusions about the effectiveness of physiotherapy. ${ }^{25,04}$ In future studies, therefore, it is important to examine health-status characteristics and their impact on distinct levels of functioning, rather than on the medical diagnosis.

On the one hand, the findings in this study lead to the conclusion that the more severe the health problem, the more likely the patient is to be referred for physiotherapy treatment. On the other hand, the more severe and/or chronic the condition of the patient, the worse the prognosis of early recovery, and the more treatment sessions required.

However, an increase in the number of sessions per treatment episode is an outcome measurement with cost implications. Knowledge of: the expected number of treatment sessions, and the determinants of the actual number of treatment sessions related to functional outcome, is therefore extremely relevant for health care policy makers with regard to the maximum number of treatment sessions per episode of care. Since the recently introduced remuneration. system for physiotherapy was changed from 12 to 9 sessions, this further limits the number of sessions per time period or by medical diagnosis oer indication per vear. For patients with complementary insurance, an additional number of 9 sessions is reimbursed, resulting in a maximum number of 18 sessions per indication per year. This remuneration system, related to a restricted number of treatment sessions, may drastically affect utilization related to the optimal achievable functional outcome of physiotherapy treatment. One of the findings of this study was that $53 \%$ of the patients were treated in 9 or less treatment sessions and that $17 \%$ of the patients were treated in more than 18 treatment sessions per episode of care. The overall mean number of treatment sessions for a range of musculoskeletal disorders in our study was 11.6 $(\mathrm{sd}=7.8)$, including the one-time consultation. This means that about half of the patients have to pay the additional costs of physiotherapy treatments (above 9) themselves when they do not have additional health insurance. The mean number in our study was one less than the mean number of treatment sessions $(13 ; s d=11])$ for patients directly referred for physiotherapy treatment, as catalogued in the national reference base, ${ }^{10.11}$ with (at least) comparable functional outcomes. Almost $70 \%$ of the patients - included in the national reference group - referred by GPs for physiotherapy treatment self-rated their functional outcome as substantially or completely improved, ${ }^{10,11}$ compared with $78 \%$ of self-rated improvement of the patients - treated by PTs following the consultation - or with the $84 \%$ of the patients who were improved substantially or completely as rated by the physiotherapist on both impairment and disability levels.

The challenge for the physiotherapy profession is to optimize functional status for persons with a higher prevalence of physically, emotionally, and socially disabling musculoskeletal conditions within acceptable costs, ${ }^{65.77}$ and also to neutralize unexplained 
clinical variation among physiotherapists and unnecessary heterogeneity in the processes used to care for patients. Current knowledge about psycho-educative strategies ${ }^{73.74}$ and about psychosocial factors affecting treatment outcomes, ${ }^{68.70}$ such as chronic pain behavior, fear/avoidance beliefs, and anxiety ${ }^{68.71 \cdot 73}$ must be applied when developing systems for more uniform musculoskeletal illness management. This requires continuous education of physiotherapists in evidence-based treatment strategies, ${ }^{2,21,23.75-77}$ and stresses the importance of coping behavior and methods of patient education to enhance adherence to treatment and to change negative behavior patterns. ${ }^{68,73,78-80}$

\section{Limitations of the study}

Although the results of this study were promising, it had several of the usual limitations of a real-world observational study. Its limitations include: (1) It was not designed as a randomized comparison. The availability of concurrent data from the national reference database strengthened the study's results by providing an opportunity for the comparison of utilization outcome data, and solved part of the validation problem. (2) The functional outcome measures by themselves were crude, and greater detail is needed for a more profound understanding of physiotherapy service utilization. However, measuring the functional outcome in terms of impairments and disabilities from the physiotherapist's point of view, and measuring the subjective recovery on a five-point scale, may have helped reflect the actual functional state from the patients' point of view. (3) The study made use of physiotherapist's self-reports of the effects on improvement rates. Self-report measures are known to be susceptible to bias. ${ }^{81}$ However, we also used the patient's selfrated outcome on the perceived benefit of physiotherapy treatment. The (functional) outcome, measured by both the patient and physiotherapist, are of the same order. (4) The results of the study are also limited by the fact that only the outcomes of physical therapy services were examined. The outcomes of treatment by other health professionals as well as the long-term results for patients treated by the GP, medical specialist or a physiotherapist were not noted.

For the above reasons, one should be cautious in the interpretation of the study's findings. The multiple comparisons suggest statistically significant findings that may have occurred by chance alone, although almost all of the statistical comparisons were in the same direction. Nevertheless, the results suggest that a one-time physiotherapist's consultation increases communication with the GP and leads to more appropriate referral for physiotherapy treatment, joint care, and satisfying functional outcomes. Specifically, this is true when we consider the heterogeneous group of patients with musculoskeletal disorders referred for a one-time consultation, in which the indication for physiotherapy treatment is not entirely clear to the GP.

Physiotherapist's consultation can contribute to an integration of care disciplines but requires good communication skills to ensure good results. Successful implementation of a one-time physiotherapist's consultation requires additional training of consultative and professional communication skills training for health care professionals; it is recommended that such educational programs be further developed. 


\section{Conclusion}

The results of the study suggest that a one-time physiotherapist's consultation with GPs leads to a better utilization of physiotherapy services. Patterns of utilization of physiotherapy services after a one-time physiotherapist's consultation were related to a decrease in physical functioning, and differences in demographic and health-status-related patient characteristics. Future studies should use more specific physiotherapy diagnostic categories rather than the broad range of medical categories only, when studying the effectiveness and efficiency of physiotherapy treatment. Although the results of this study may not be universalized, it provides a starting point for further research to optimize interdisciplinary collaboration (and communication), and utilization of physiotherapy services, to achieve optimal patient outcomes, and thus reduce health care costs.

\section{References}

1. Swanson G. Use of outcome reports: justifying the need for physical therapy services. Orthopaedic Physical Therapy Clinics of North America 1995;4:253-268.

2. Hendriks HJM, Oostendorp RAB, Bernards ATM, Van Ravensberg CD. Heerkens YF, Nelson RM. The diagnostic process and indication for physiotherapy: a prerequisite for treatment and outcome evaluation. Physical Therapy Reviews 2000;5:29-47.

3. LHV (Landelijke Huisartsen Vereniging) 1987 Het basistakenpakket van de huisarts. LHV Vademecum: Utrecht, 1987.

4. Geijer RMM, Burgers JS, Van der Laan JR, Wiersma TJ, Rosmalen CFH, Thomas S [Eds]. NHGStandaarden voor de huisarts, deel 1. Maarssen: Elsevier/Bunge, 1999.

5. Bersee APM, Pluimakers WHMA. De Wet BIG: de betekenis van de nieuwe wetgeving voor beroepsbeoefenaren in de gezondheidszorg. Vermande: Lelystad, 1993.

6. Kerssens J, Curfs EChr. Extramurale fysiotherapie (PhD dissertation). Netherlands Institute for primary health care (Nivel): Utrecht, 1993.

7. Rijken PM, Van Heugten CM, Dekker J. Brancherapport paramedische zorg. Nederlands instituut voor onderzoek van de gezondheidszorg (Nivel): Utrecht, 1996.

8. Oostendorp RAB, Van Ravensberg CD, Wams HWA, Heerkens YF, Hendriks HJM Fysiotherapie, wat omvat het? Bijblijven 1996:12:5-17.

9. Uunk W, Dekker J, Groenewegen P. Verwijzingen van huisartsen naar fysiotherapeuten: morbiditeitsspecifieke verwijspercentages. Deelproject Huisarts en fysiotherapeutische zorg: Basisgegevens uit de Nationale Studie van. Ziekten en Verrichtingen in de Huisartsenpraktijk. Nivel: Utrecht, 1991.

10. Dekker J, van Baar ME (eds). Beleidsgericht Evaluatie- en Effectonderzoek Extramurale Fysiotherapie 1989-1992. Nederlands instituut voor onderzoek van đe gezondheidszorg (Nivel): Utrecht, 1995.

11. Van der Valk R. Dekker J, Boschman M. Basisgegevens extramurale fysiotherapie 1989-1992. Gegevens uit het project "Beleidsgericht Evaluatie- en Effectonderzoek Fysiotherapie (BEEF)". Nivel: Utrecht, 1995.

12. Lamberts H. In het huis van de huisarts. Verslag van het Transitieproject. Meditekst: Lelystad, 1991.

13. Uili RM, Shepard K, Savinar E. Physician knowledge and utilization of physical therapy procedures. Physical Therapy $1984 ; 64: 1523-1530$.

14. Stanton PE, Fox FK, Francois KM, Hoover DH, Spilecki GM. Assessment of resident physicians' knowledge of physical therapy. Physical Therapy 1985;65:27-30.

15. Hulme JB, Wackernagel B, Lewis JW. Communication between physicians and physical therapists. Physical Therapy 1988:68:26-31.

16. Hendriks HJM. Wagner C. Dekker J, Brandsma JW. Evaluatie van het consultatief fysiotherapeutisch onderzoek in de eerste lijn. Resultaten van een veidexperiment. Nivel: Utrecht, 1994. 
17. Hendriks HJM, Wagner C, Brandsma JW, Oostendorp RAB, Dekker J. Experiences with physiotherapist's consultation. Results of a feasibility study. Physiotherapy Theory and Practice 1996:12:211-20.

18. Van den Heuvel. Samenwerking huisarts-fysiotherapeut. Bijblijven 1996;12:66-72.

19. Beckerman H, Bouter LM, Van der Heijden GJMG, De Bie RA, Koes BW. Efficacy of physiotherapy for musculoskeletal disorders: what can we learn from research? British Journal of General Practice 1993;43:73-7.

20. Newman DJ. Physiotherapy for best effect. Physiotherapy 1997;83:5-I1.

21. MacIntyre DL, McAuley CA, Parker-Taillon D. Canadian physiotherapy research and evidence-based practice initiative in the 1990s. Physical Therapy Reviews 1999;4:127-137.

22. Higgs J, Titchen A. Research and Knowledge. Physiotherapy 1998;84:72-80.

23. Hendriks HJM, Bekkering GE, Van Ettekoven H, Brandsma JW, Van der Wees Ph, De Bie RA. Development and implementation of national practice guidelines: a prospect for continuous quality improvement in physiotherapy. An introduction to the method of guideline development (Part 1). Physiotherapy 2000;86;535-547.

24. Hendriks. HJM, Wagner C. Brandsma JW, Dekker J, Wams HWA, Oostendorp RAB. Consultatief Fysiotherapeutisch Onderzoek (CFO) in de eerste lijn. Introduktie van het CFO-project en informatie uit de literatuur. Nederlands Tijdschrift voor Fysiotherapie 1992:102:176-183.

25. Mielenz TJ. Carey TS, Dyrek DA, Harris BA, Garrett JM, Darter JD. Physical therapy utilization by patients with acute low back pain. Physical Therapy 1997;77:1040-1051.

26. Overman SS, Kent DL, Uslan DW, Lewis RS. Cost of care and patient-satisfaction from routine referral to nonsurgical musculoskeletal specialists in a medicare risk plan. Journal of Clinical Rheumatology 1998; $4: 120-128$.

27. Moncur C. Perceptions of physical therapy competencies in rheumatology. Physical therapists versus rheumatologists. Physical Therapy 1987;67:331-39.

28. Hart E, Pinkston D, Ritchey FJ, Knowles CJ. Relationship of professional involvement to clinical behaviors of physical therapists. Physical Therapy 1990;70:179-87.

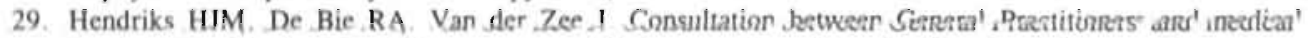
consultants in the Dutch health care system. What can we learn from the literature? (submitted).

30. Hulka B, Wheat JR. Patterns of utilization: the patient perspective. Medical Care 1985;23:438-460.

31. Akpala CO, Curran AP, Simpson J. Physiotherapy in general practice: patterns of utilization. Public Health 1988:102:263-68.

32. Ritchey FJ, Pinkston D, Goldbaum JE, Heerten ME. Perceptual correlates of physician referral to physical therapist: Implications for role expansion. Social Science \& Medicine 1989;28:69-80.

33. Anderson J, Campbell SK. Correlates of physician utilization of physical therapy. International Journal of Technology Assessment in Health Care 1992;8:10-19.

34. Dekker J, Van Baar ME, Curfs EChr, Kerssens JJ. Diagnosis and treatment in physical therapy: an empirical investigation of their relationship. Physical Therapy 1993;73:568-580.

35. Jette AM, Smith K. Haley SM, Davids KD. Physical therapy episodes of care for patients with low back pain. Physical Therapy 1994;74:101-115.

36. Jette AM. Jette DU. Physical therapy and health outcomes in patients with spinal impairments. Physical Therapy 1996:76:930-941.

37. Jette DU, Jette AM. Professional uncertainty and treatment choices by physical therapists. Archives of Physical Medicine and Rehabilitation 1997:78:1346-1351.

38. Jette AM, Delitto A. Physical therapy treatment choices for musculoskeletal impairments. Physical Therapy 1997:77:145-154.

39. Yoshida KK, Allison KR. Sociodemographic and health-related. characteristics of Ontarians making contact with physical therapists: analysis of the 1990 Ontario health survey. Physiotherapy Canada 1997:49:214221.

40. Kerssens JJ, Groenewegen PP. Referrals to physiotherapy: The relation between the number of referrals, the indication for referral and the inclination to refer. Social Science \& Medicine 1990:30:797-804.

41. Uunk WJ̣G. Groenewegen PP, Dekker J. Verwijzingen van huisartșen naar fysiotherapeuten: ẹn vẹklaring en analyse van verschillen tussen huisartsen. Mens en Maatschappij 1992:67:389-411

42. Zuijderduin W, Dekker J, Abrahamse H. Determinanten van de omvang van de behandeling in de extramurale fysiotherapic. Tijdschrift, voor Sociale Gezondheidszorg 1995;73:274-281. 
43. Van Ravensberg CD, Van Klaveren AA, Wams HWA, Oostendorp RAB, Elvers JWH, Hendriks HJM. Variabelen in samenhang met aantal behandelingen fysiotherapie: analyse FON-PPP-gegevens. Nederlands Paramedisch Instituut (NPi): Amersfoort, 1995.

44. Roebroeck ME, Hutten JBF, Kerssens JJ, Dekker J. De omvang van de fysiotherapeutische behandeling naar verschillende patièntencategorieèn. Nederlands instituut voor onderzoek van de gezondheidszorg (Nivel): Utrecht, 1995.

45. Roach KE, Ally D, Finnerty B, Watkins D, Litwin BA, Janz-Hoover B, Watson T, Curtis KA. The relationship between duration of physical therapy services in the acute care setting and change in functional status in patients with lower-extremity orthopedic problems. Physical Therapy 1998;78:19-24.

46. Freburger JK. An analysis of the relationship between the utilization of physical therapy services and outcomes for patients with acute stroke. Physical Therapy 1999:79:906-918.

47. Hendriks HJM, Kerssens JJ, Bekkering GE, Dekker J, Oostendorp RAB, Van der Zee J. Determinants of the number of sessions per physiotherapy treatment episode (submitted).

48. Hendriks HJM, Kerssens JJ, Dekker J, Oostendorp RAB, Van der Zee J, Nelson RM. Physical therapist consultation in general practice: its use and impact on the process of care. Physical Therapy (accepted).

49. Van der Velden J, De Bakker DH, Claessens AAMC, Schellevis FG. Nationale studie naar ziekten en verrichtingen in de huisartsenpraktijk. Basisrapport: Morbiditeit in de huisartsenpraktijk. Netherlands institute of primary health care (Nivel); Utrecht, 1991.

50. WHO (World Health Organization). International Classification of Impairments, Disabilities, and Handicaps (ICIDH): a manual of classification relating to the consequences of discase. WHO: Geneva, 1980.

51. WHO (World Health Organization). International Classification of Impairments, Activities and Participation: a manual of dimensions of disablement and functioning (ICIDH-2). WHO: Geneva, 1997.

52. Heerkens YF, Brandsma JW, Lakerveld-Heyl K, Van Ravensberg CD. Impairments and disabilities - The difference. Proposal for Adjustment of the International Classification of Impairments, Disabilities, and Handicaps. Physical Therapy 1994;74:430-442.

53. Hendriks HJM, Brandsma JW. Heerkens YF, Oostendorp RAB, Nelson RN. Intraobserver and interobserver reliability of assessments of impairments and disabilities. Physical Therapy 1997;77:1097. 1106.

54. Lamberts H, Wood M. International Classification. of Primary Care (ICPC) Oxford University Press: Oxford, 1987.

55. KNGF (Koninklijk Nederlands Genootschap voor Fysiotherapie). Richtlijnen voor de fysiotherapeutische verslaglegging. KNGF: Amersfoort, 1993.

56. Joint Working Party of the Welsh Council of the Royal College of General Practitioners and the Welsh General Medical Services Committee. Patient care and the general practitioner. British Medical Journal 1994:309:1144-47.

57. American Board of Internal Medicine. A statement on the generalist physician from the American Boards of family practice and internal medicine. JAMA 1994;271:315-316.

58. RIVM (Rijksinstituut voor Volksgezondheid en Milieu). Volksgezondheidtoekomst-verkenningen 1997. Effecten van zorg. Elsevier / De Tijdstroom: Bitthoven, 1997.

59. CBS (Centraal Bureau voor de Statistiek). Statistisch Jaarboek 1997. Voorburg: CBS, 1998.

60. Lubeck DP. The economic impact of arthritis. Arthritis Care Res 1995:8:304-310.

61. Yelin E, Callahan L. The economic costs and social and psychological impact of musculoskeletal conditions. Arthritis Rheum 1995;38:1351-1362.

62. Kersten TJJMT. De invloed van de huisarts op de specialist. Een theoretische analyse getoetst aan de opvattingen van huisartsen. Tijdschrift voor Sociale Gezondheidszorg 1992;70:171-179

63. Van Hedel H. Het Consultatief Fysiotherapeutisch Onderzoek (CFO) in de Eerste Lijn. Patiëntkenmerken, prognose en resultaat van fysiotherapie van patiénten die na een CFO zijn verwezen voor fysiotherapie. Nederlands Paramedisch. Instituut (NPi) - Katholieke Universiteit Nijmegen (KUN): Amersfoort/Nijmegen, 1998.

64. Van der Windt. DAWM, Koes BW, Boeke AJP, Deville W, De Jong B, Bouter LM. Shoulder disorders in general practice: prognostic indicators of outcome. British Journal of General Practice 1996:46:519-523.

65. Jette AM. Physical disablement concepts for physical therapy research and practice. Physical Therapy: $1994: 74: 380-386$.

66. Verbrugge LM, Jette AM 1994 The disablement process. Social Science \& Medicine 38:1-14 
67. Johnston M. Models of disability. Physiotherapy Theory and Practice 1996;12:131-141.

68. Waddell G. The Back Pain Revolution. Churchill Livinstone: Edingburgh, 1998.

69. Hope Ph, Forshaw MJ. Assessment of psychological distress is important in patients presenting with low back pain. Physiotherapy 1999;85:563-570.

70. Linton SJ, Hallden K. Can we screen for problematic back pain? A screening questionnaire for predicting outcome in acute and sub-acute back pain Clinical Journal of Pain 1998:14:200-215.

71. Main CJ, Watson PJ. Screening for patients at risk of developing chronic incapacity. Journal of Occupational Rehabilitation 1995;5:207-217.

72. Vlaeyen JWS, Kole-Snijders AMJ, Boeren RGB, Van Eek H. Fear of movement / (re)injury in low back pain and its relation to behavioral performance. Pain 1995;62:363-372.

73. Turk DC. The role of demographic and psychosocial yellow flags in physiosocial factors in transition from acute to chronic pain. In: Jensen TS, Turner JA, Wisenfeld-Hallin Z (eds). Proceedings of the eight World Congress on Pain, Progress in Pain Research and Management, pp 185-213. 8 IASP Press: Seattle, 1997.

74. Hopman-Rock M. Coping with osteoarthritis of the knee and/or hip: the development of a lifestyle programme. TNO Preventie en gezondheid: Leiden (The Netherlands), 1994.

75. De Bie RA, Verhagen AP. De relevantie van effectonderzoek in de fysiotherapie. In: Smits-Engelsman, Van Ham I, Aufdemkampe G, Den Dekker JB, Vaes P (eds), Jaarboek Fysiotherapie / Kinesitherapie, pp 1-15. Bohn Stafleu Van Loghum: Houten/Diegem, 1998.

76. Turner PA, Whitfield TWA. Physiotherapists' reasons for selection of treatment techniques: a cross-national survey. Physiotherapy Theory and Practice 1999;15:235-246.

77. Hendriks HJM, Van Eutekoven H, Bekkering GE, Verhoeven A. Implementatie van KNGF richtlijnen: van theorie naar praktijk. Fysiopraxis 2000:9(2):9-13.

78. Sluijs EM, Kerssens JJ, van der Zee J. Adherence to physiotherapy. In: Myers L, Midence K (eds), Adherence to medical treatment. Harwood Academic Publishers: Reading (England), 1998.

79. Kerssens JJ, Sluijs WM, Verhaak PFM, Knibbe HJJ, Hermans IMJ. Back care instructions in physical therapy: a trend analysis of individualized back care programs. Physical Therapy 1999;79:286-295.

80. Watson PJ. Psychosocial assessment. The emergence of a new fashion, or a new tool in physiotherapy for musculoskeletal pain? Physiotherapy 1999:85:530-535.

81. De Bie RA. Efficacy of $904 \mathrm{~nm}$ laser therapy in acute lateral ankle sprains ( $\mathrm{PhD}$ dissertation). Datawyze/Maastricht University Press: Maastricht, 1998. 


\title{
Determinants of the Number of Sessions per Physiotherapy Treatment Episode
}

\begin{abstract}
Objective. To determine patient, physiotherapist and practice setting characteristics associated with the number of sessions per physiotherapy treatment episode of patients referred by a general practitioner (GP). Methods. Data of complete treatment episodes were collected during an observational study. Hierarchical logistic regression modelling was used to estimate the probability of being treated within 9 versus 10 or more sessions (9-sessions model) or within 18 versus 19 or more sessions per treatment episode (18sessions model). Subjects. The database contains information on 2,574 therapy sessions for 224 patients with a broad range of musculoskeletal disorders, who were treated by 53 physiotherapists working in different private practices in primary care. Results. The mean number of sessions per treatment episode was 11.5 ( $(\mathrm{dd}=7.8$ ), ranging from 3 to 34 . Fiftythree percent of the patients were treated in 9 treatment sessions or less. Among the included patient characteristics, only the patient's age was found to be related to the probability of being treated within 9 versus 10 or more sessions per treatment episode. Among the included physiotherapist and practice characteristics, the age of the physiotherapist, specialization in manual therapy and pediatric physiotherapy, and the number of professional partners in the practice were found to be important determinants of the volume of physiotherapy care. Conclusion. The variation in the number of sessions per treatment episode may be influenced by physiotherapist and practice characteristics, and not only by the patient or clinical status characteristics. It is recommended that these findings be studied in further research that includes other factors such as the physiotherapist's behavior, attitude toward patient care, and level of education. This may identify additional sources of clinical variation.
\end{abstract}




\section{Introduction}

A program of physiotherapy consists of a number of treatment sessions. Since 1991, the remuneration system by health insurance companies to physiotherapists in The Netherlands has been based on the number of sessions per treatment episode, regardless of the types of services provided or the choice of modalities. The total number of sessions per treatment episode, however, is an outcome measurement with cost implications. Epidemiological research has shown wide variations in treatment patterns, ${ }^{1-9}$ and number of sessions per treatment episode in physiotherapy practice..$^{2,10-15}$ One hypothesis regarding the cause of this wide variation in treatment sessions is the lack of definitive evidencebased practice guidelines, and the multiple goals and outcomes of physiotherapy care. ${ }^{8.16-18}$

The efficacy of physiotherapy treatment is not yet well-established. ${ }^{16-21}$ The need for the profession of physiotherapy to illustrate its value to the external world is becoming more obvious each year. Owing to the lack of documented evidence to support a number of physiotherapy interventions, and the issue of cost-containment, the remuneration system for physiotherapy in The Netherlands was changed in 1996 to limit the number of physiotherapy treatment sessions to 9 (or, with complementary insurance, a maximum of 18) per indication per year. This may drastically affect the achievable functional outcome of physiotherapy treatment. Knowledge of the determinants of the number of sessions per treatment episode is therefore extremely relevant for health care policy makers, the profession, and the patient.

Although the literature provides a considerable amount of information about the extent of variation in practice patterns ${ }^{2.5-11}$ and the number of treatment sessions per episode of care, ${ }^{2.15}$ it is less complete in addressing the problem of identifying the sources of this variation. The relatively few investigations into the determinants of the number of sessions per treatment episode (thus the costs of physiotherapy treatment) have focused specifically on patient characteristics. ${ }^{11-15}$ It is suggested that patients' demographic and functional (health)-status-related characteristics may be indicative of utilization of physiotherapy services, and the number of sessions per treatment episode. Based on a large survey (17,201 patients) of physiotherapy practice in the Dutch primary health care system, ${ }^{4.5}$ Zuijderduijn and co-authors " demonstrated that the variability in the number of sessions per treatment episode was significantly associated with the physiotherapist's diagnostic findings in terms of impairments and disabilities, the duration of the complaints, the medical diagnosis, and the age of the patient. However, the total explained variance of these factors amounted to only 17 percent. Thus, the variation in the number of sessions per treatment episode persisted even when adjustment was made for the patients. demographic, medical diagnostic and functional (health)-status-related characteristics.

To the marginal extent that 'explanations' of clinical variation and volume of care are offered by differences in patient characteristics, these tend to be divided between looking at characteristics of patients and characteristics of physiotherapists and their practices. Although most physiotherapists would probably say the variation in the number of 
treatment sessions is predicated on the clinical (health) status of the patient, the variability in practice patterns and number of sessions per treatment episode may also be affected by the physiotherapists" different clinical experiences or levels of education, ${ }^{8}$ treatment preferences, ${ }^{22}$ area of specialization, behavior and attitudes toward patient care, $2 ., 17,18,23,24.25$ and in the difference between practices (e.g. number of professional partners, and level of urbanization). ${ }^{1,28,14-18}$

To our knowledge, no research has been conducted that contributed to an understanding of the characteristics of physiotherapists and the practice setting related to the variation in number of sessions per treatment episode.

The objective of this study is to identify characteristics of physiotherapists and their practice setting that affect the total number of sessions per treatment episode, controlled for by patient characteristics.

\section{Methods}

\section{Design}

The methods of this study have been described in more detail in other reports, ${ }^{25} \cdot 2 \mathrm{and}$ are briefly summarized in the following paragraphs. A group of patients referred by GPs for a one-time physiotherapist's consultation was studied in a 7-month observational study with a follow-up of all patients applying for physiotherapy treatment following consultation (between October 1992 and February 1994). The number of sessions per treatment episode of all patients being treated by a physiotherapist was recorded and used in this study as the main outcome variable.

The study was conducted among 59 randomly selected physiotherapists, drawn from the total physiotherapist population as listed in the: (Netherlands) national database, working in different practices in primary care. For the purpose of this study, one randomly selected physiotherapist was paired with one GP matched for degree of urbanization. The GP was randomly selected from a list of GPs who had a regular referral relationship with the participating physiotherapist. If a selected GP did not agree to participate, another GP was randomly selected from that list. The response rates for physiotherapists and GPs agreeing to participate in the study was $82 \%$ and $74 \%$, respectively.

The physiotherapists were trained in the process of a one-time consultation, the use of standardized registration and report forms, including operational definitions, and data collection procedures. No attempt was made to influence the GPs' management decisions, and all patients received information about the purpose and procedures of the study.

\section{Patients}

The database contained information about 224 patients treated by 53 out of 59 physiotherapists following a one-time physiotherapist's consultation, and 2,574 treatment sessions. Data of complete treatment episodes were collected between October 1992 and 
February 1994. All patients were referred for physiotherapy treatment due to complaints of the locomotor system (for more detailed information, see Hendriks et $\mathrm{al}^{25-28}$ ).

The average number of patients treated by a physiotherapist following a one-time physiotherapist's consultation was $4.6(\mathrm{sd}=3.2$; range $=1-12)$.

\section{Physiotherapist and practice setting characteristics}

The participating physiotherapists had a mean age of 36.7 years $(s d=6.1)$. The majority of the physiotherapists $(66 \%)$ were male, and had extensive professional experience in terms of years of establishment in primary care $(59 \%$ longer than 10 years). Comparing the data of the selected therapists with the data of all physiotherapists working in primary health care $(\mathrm{n}=10,187)$ shows a good fit in terms of gender, age and type of post-graduate courses or specialties. ${ }^{25}$ The specialties of the 53 physiotherapists (as acknowledged by the Royal Dutch Physiotherapy Association) were: 15 manual therapists, 15 sports physiotherapists, 6 pediatric physiotherapists, and 5 therapists trained in women's health problems. The distribution of the private practices of participating physiotherapists showed an under-representation of single-handed practices (11\% vs $35 \%)$, an over-representation of group practices (more than one partner: $81 \%$ vs $44 \%$ ), and a greater-than-average work experience in primary care. Thirty-nine physiotherapisis (74\%) were sufficiently $(28 / 53)$ or very $(11 / 53)$ satisfied with their cooperation with their matched GP.

Seventeen of 53 physiotherapists (32\%) were established in urban areas (cities with more than 50,000 inhabitants).

Sample selection and representation of physiotherapists and GPs has been described in detail by Hendriks et al. ${ }^{25.27 .28}$

\section{Outcome variable}

For the purpose of this paper, the outcome variable was the total number of sessions per treatment episode. With reference to the recently changed remuneration system for physiotherapy to limit the total number of sessions per treatment episode to 9 sessions (or with a complementary insurance to a maximum of 18) per indication per year, the outcome variable was studied on 2 different cut-off points: (1) 9 treatment sessions or less versus 10 or more, and (2) 18 sessions or less versus 19 or more.

\section{Predictor variables}

Based on the health service utilization literature, ${ }^{29}$ and on actual physiotherapy practice, $2.15,30.34$ the following variables were seen to have a potential impact on the total number of sessions per treatment episode. The predictor (or independent) variables at the level of the patient were personal, demographic and health-status-related characteristics. The personal and demographic characteristics were age, gender, marital and employment status, level of education, and health insurance. The health-status-related characteristics were the duration of the complaints. psychosocial complaints, previous physiotherapy treatment for the same complaint, previous visits for diagnostic testing and/or therapy for the same complaint by other health professionals in the past 12 months, types of disorders 
or conditions, and functional status in terms of impairments and disabilities according to the International Classification of Impairments, Disabilities, and Handicaps, ${ }^{35.36}$ The physiotherapist assessed whether an impairment or disability was present, and indicated its severity on a three-point Likert scale. A standard form was designed and listed 36 impairments and 27 disabilities as a generic tool for assessing physical functioning (see Appendix). ${ }^{37}$ In a reliability study, the interobserver reliability of these items was found to be sufficiently high. ${ }^{37}$ For each patient, the physiotherapist could register several impairments and disabilities in order to assess functional status.

The types of complaints, disorders or conditions were classified according to the International Classification of Primary Care (ICPC). Only the 10 most frequent complaints or disorders were used in the analysis.

During the discharge visit, the physiotherapist reported on a standard registration form the total number of sessions provided and the duration of the treatment episode. A treatment episode was defined as all therapy sessions provided between the initial and discharge session.

The predictor variables at the level of the physiotherapist obtained by self-administered questionnaires included: age, gender, years of experience in primary care, type of specialty, and perception about their cooperation and frequency of communication concerning their patients with the matched GP. The practice characteristics were the number of professional partners and level of urbanization (rural, semiurbanized, urban). ${ }^{2.39}$ All data were provided by each practice, physiotherapist, and patient on standardized (data collection) forms and questionnaires.

\section{Data Analysis}

Statistics were used to describe the personal, demographic, (functional) health-statusrelated characteristics of the patients, and the actual number of sessions per treatment episode. Data on the number of sessions were aggregated at the level of treatment episodes. All data were entered into SPSS-X (Release 4.1. Chicago, III: SPSS Inc; 1991) for analysis.

The data were analyzed by means of a special form of logistic regression analysis (hierarchical logistic regression analysis [HLM]) to determine which variables were associated with the number of sessions per treatment episode ${ }^{40,41}$ HLM was used because the data set had an intrinsically hierarchical nature as a result of the 2-stage sample of patients (lower level) who were nested within the sample of physiotherapists (higher level) ${ }^{42}$ Thus, we had information about sessions, patients, and physical therapists. ${ }^{42,43}$ The data, therefore, were not from independent observations, violating a major assumption of traditional logistic regression analysis. In HLM, both of these factors are taken into account. Several health services research projects have applied HLM. ${ }^{43-46}$ Data analysis was carried out by means of MLN software. ${ }^{47}$ 
Table 1. Mean number (SD) and distribution of treatment sessions in categories of three sessions per treatment episode

\begin{tabular}{lcrl}
\hline & \multicolumn{2}{l}{ No. of patients $(\%)(\mathrm{n}=224)$} & \\
\cline { 2 - 4 } Treatment sessions* & No. & $(\%)$ & cum. \% \\
\hline $1-3$ & 12 & $(5 \%)$ & $27 \%$ \\
$4-6$ & 49 & $(22 \%)$ & $53 \%$ \\
$7-9$ & 58 & $(26 \%)$ & $74 \%$ \\
$10-12$ & 47 & $(21 \%)$ & $80 \%$ \\
$13-15$ & 14 & $(6 \%)$ & $83 \%$ \\
$16-18$ & 7 & $(3 \%)$ & $100 \%$ \\
$>19$ & 38 & $(17 \%)$ & \\
Mean (SD) & & & \\
\hline
\end{tabular}

The simultaneous influence of various predictor variables on the 2 dichotomized number of treatment sessions was examined. This method allows for the direct estimate of the probability of being treated, for example, within 9 sessions or less versus 10 or more per treatment episode. Selection criteria for including patient and physiotherapist characteristics were based on the results of bivariate analysis between the predictor variables and the number of treatment sessions.

Those significantly related variables for each model were retained for further analysis. The number of potential predictor variables was restricted in the analysis of smaller subsets of patients to make sure that the models contained at least 10 percent of the cases per variable. The models were fitted by stepwise-forward selection of individual patient, physiotherapist, and practice characteristics $\left(\mathrm{P}_{\text {in }}<0.05\right)$. The predictor variables were entered consecutively in two distinct blocks: (1) personal and sociodemographic variables, functional and health-status-related variables (including the medical diagnostic groups and the impairments and disabilities) of the patient; and (2) the characteristics of the physiotherapists and their practices.

Indicator coding was used for categorical predictor variables in the logistic analysis, with the first category in each group treated as the reference group. The contribution of the various predictor variables in the analysis was expressed in regression coefficients (B) and their standard errors (SE). If their division is greater than 1.96 or smaller than -1.96 , the coefficient is statistically significant (alpha level $=.05$ ), as in normal logistic regression analysis. The strength of the associations in the final model were expressed in odds ratios (OR) with $95 \%$ confidence intervals (CI). 


\section{Results}

\section{Number of sessions per treatment episode}

The average number of sessions per treatment episode was 11.5 per patient ( $\mathrm{sd}=7.8$; range $=3-34)$. Table 1 shows that $27 \%$ of the patients $(60 / 224)$ were treated in 6 treatment sessions or less, 53\% (118/224) were treated in 9 sessions or less, and $74 \%(165 / 224)$ were treated in 12 sessions or less. In $17 \%(38 / 224)$ of the patients, the physiotherapists needed more than 18 sessions per treatment episode.

The patients were treated for an average of 7.3 weeks $(s d=6.4)$, with the length of treatment episodes ranging from 1 week to 38 weeks.

\section{Bivariate analysis}

In the initial bivariate analysis, we examined the relationships between the predictor variables and the criterium variable on the probability of being treated within (1) 9 treatment sessions or less versus 10 or more (9-sessions model), and (2) within 18 sessions or less versus 19 or more (18-sessions model).

Eighteen of the 36 impairments and 17 of the 27 disabilities, respectively, had a prevalance of 10 percent or more and were included for further analysis. Patient characteristics used for the bivariate analysis are shown in Table 2.

As a result of the bivariate analysis, 15 patient variables appeared to be related to the probability of being treated within 9 sessions, and 9 patient variables appeared to be related to the probability of being treated within 18 sessions per treatment episode.

As a result of the bivariate analysis on the level of the physiotherapists and their practices, 5 variables appeared to be related to the probability of being treated within 9 sessions, and 5 variables appeared to be related to the probability of being treated within 18 sessions per treatment episode. The physiotherapist and practice characteristics used for the analysis were described in the method section of this paper. All significant bivariaterelated variables for each model separately, are listed in Table 3.

For example, in the first 9-sessions model 3 demographic and 12 functional or healthstatus-related variables were associated with the probability of being treated within 9 treatment sessions or less versus 10 or more. Male and privately insured patients were associated with the probability of being treated within 9 sessions or less, whereas an increase in patient age was associated with a higher probability of being treated in 10 sessions or more. The health-status-related variables suggested that previous medical therapy for the same complaint in the past 12 months, and patients with back disorders, were associated with the probability of being treated in more than 9 treatment sessions. Patients who had been previously treated by physiotherapy within the last year were more likely to be treated within 9 sessions. The impairments in range of motion (decreased), body posture, and joint position, and disabilities in changing postures, in carrying, and bending over, and the number of disabilities, were associated with a higher probability of being treated in more than 9 sessions, whereas decreased muscle tone, and 
edema/swelling, were associated with a higher probability of being treated within 9 sessions.

Physiotherapists with the characteristics of: age of 45 years or more; skilled in manual therapy; and working with one professional partner or more (practice characteristic); were more likely to treat patients within 9 sessions or less. Physiotherapists skilled in pediatrics or women's health problems were more likely to treat patients in 10 or more sessions.

\section{Multiple logistic regression analysis}

When all the significantly related variables, as a result of the initial bivariate analysis, were included for hierarchical (multiple) logistic regression analysis, the influence of the physiotherapist and practice characteristics appeared to be the most powerful in both models (see Table 3 ).

This is clearly indicated by a decrease in significantly related patient variables when the physiotherapist and practice variables were introduced as the last block of variables.

For example, in the first model - 9 treatment sessions or less versus 10 or more -- 15 patient variables and 5 physiotherapist/practice variables were included.

In the 9-sessions model, 5 of the 15 bivariate-related patient variables (age, health insurance, prior medical therapy, or physiotherapy for the same complaint/disorder, and edema/swelling) versus all of the included bivariate-related physiotherapist variables (age of the physiotherapist; physiotherapists skilled in pediatrics, manual therapy, and women's health; and number of professional partners) remained significant. None of the various (functional) health-status-related variables (e.g. impairments and disabilities), except edema/swelling appeared to be important predictors of the variability in number of sessions per treatment episode.

Physiotherapists working in a group practice (one partner or more), physiotherapists with an age of 45 years or more, or physiotherapists skilled in manual therapy were more likely to treat patients within 9 treatment sessions or less, whereas physiotherapists skilled in pediatrics were more likely to treat the patients in more than 9 sessions.

Although the results of the second (18-sessions) model show a similar trend, there are also some differences. In the 18-sessions model, 3 of the 9 included bivariate-related healthstatus- or functional-status-related patient variables, and 3 out of the 5 bivariate-related physiotherapist variables remained significant. Patients with joint problems, back disorders, and those who had pain following movement were treated more frequently in more than 18 sessions per treatment episode, whereas physiotherapists skilled in womens' health problems were more likely to treat patients in more than 18 sessions. The results at the level of the physiotherapist show that physiotherapists skilled in manual therapy, and physiotherapists who were satisfied with their cooperation with the matched GP, were more likely to treat patients within 18 sessions or less per treatment episode.

Table 3 shows the regression coefficients (B-values), standard errors (SE), and t-values as the result of the multiple logistic regression analysis of all significantly related bivariate variables. 
Table 2. Demographic, functional-and health-status-related characteristics of patients being treated by a physiotherapist: \% (No.) unless otherwise stated

\begin{tabular}{|c|c|c|c|c|c|}
\hline & \% & (No.) & & $\%$ & (No.) \\
\hline \multicolumn{3}{|l|}{ Demographic } & \multicolumn{3}{|l|}{ Impairments } \\
\hline Gender (male) & 46 & (106) & pain & 96 & $(218)$ \\
\hline Mean age in years (SD) & 38.2 & (15.4) & pain following movement & 80 & (179) \\
\hline Insurance (private) & 25 & (57) & pain during movement & 78 & (178) \\
\hline \multicolumn{3}{|l|}{ Education } & pain at rest & 61 & (138) \\
\hline low & 46 & (104) & pain sensation & 36 & (81) \\
\hline middle & 42 & (94) & pain behavior & 34 & (76) \\
\hline high & 12 & (26) & active stability (decreased) & 33 & (74) \\
\hline Employed (yes) & 50 & (113) & passive stability (decreased) & 17 & (39) \\
\hline Marital status (single) & 9 & (20) & coordination & 191 & (44) \\
\hline \multicolumn{3}{|c|}{ Health-status-related characteristics } & muscle tone (decreased) & 11 & (25) \\
\hline \multicolumn{3}{|c|}{ Duration complaint } & muscle strength (decreased) & 42 & (95) \\
\hline$<1$ wk & 3 & (7) & proprioception & 23. & (51) \\
\hline 1 wk - 12 wks & 39 & (87) & kinesthesia & 21 & (47) \\
\hline 13 wks -1 year & 28 & (63) & body posture & 44 & (98) \\
\hline$>1$ year & 30 & (67) & joint position & 38 & (84) \\
\hline Psychosocial problems & 25 & (56) & sensibility & 11 & (25) \\
\hline Prior physiotherapy " & 24 & (54) & edema/swelling & 14 & (31) \\
\hline \multicolumn{3}{|c|}{ Prior medical interventions" } & tiredness & 15 & (33) \\
\hline Diagnosis & 42 & (93) & Mean number (SD) & 7.5 & (3.2) \\
\hline Therapy & 22 & $(50)$ & Disabilities & & \\
\hline \multicolumn{3}{|l|}{ Affected organ/tissue } & maintaining postures & 36 & $(81)$ \\
\hline Bone & 25 & $(56)$ & changing postures & 30 & (69) \\
\hline Joint & 81 & (181) & carrying & 35 & (79) \\
\hline Muscle & 71 & $(154)$ & lifting & 32 & (72) \\
\hline Nerve & 13 & (29) & picking up & 52 & (117) \\
\hline \multicolumn{3}{|c|}{ Type of disorder in terms of $I C P C^{c}$} & reaching & 16 & (36) \\
\hline Back (L02) & 19 & (43) & moving objects & 27 & $(61)$ \\
\hline Knee (L15) & 17 & (39) & handling objects & 22 & $(50)$ \\
\hline Shoulder (L08) & 10 & (23) & grasping & 16 & (36) \\
\hline \multirow[t]{9}{*}{ Neck (L04) } & 9 & $(21)$ & bending over & 25 & (57) \\
\hline & & & walking, & 37 & (83) \\
\hline & & & climbing stairs. & 30 & (68) \\
\hline & & & cycling & 18 & $(40)$ \\
\hline & & & personal care & 9 & (20) \\
\hline & & & domestic activities & 32 & (72) \\
\hline & & & related to work & 52 & $(117)$ \\
\hline & & & related to recreation & 60 & $(134)$ \\
\hline & & & Mean number (SD) & 5.7 & $(4.0)$ \\
\hline
\end{tabular}

"for the same complaint

"more than one option was possible

' International Classification of Primary Care (ICPC) $)^{\text {!n }}$

"International Classification of Impairments, Disabilities and Handicaps (ICIDH) $)^{15.36}$ 
The two final models with only the significantly related variables entered stepwise (the patients' demographic, health-status- and functional-status-related variables, then the physiotherapists' and practice setting characteristics), are presented in Table 4 . When all the significantly related predictor variables as a result of the multiple regression analysis were included in the equation, the influence of the physiotherapist variables appeared to be an important source of the variability in the number of sessions per treatment episode.

\section{Comment}

The issue of cost-effective care continues to dominate the debate regarding strategies for organizing and financing health care services. Physiotherapists are likely to come under close scrutiny as financiers of health care services (health insurance companies) seek to find the best and most cost-effective care for people with musculoskeletal disorders. ${ }^{17}$

Knowledge of the expected number and determinants of the actual number of treatment sessions related to functional outcome is therefore extremely relevant for health care policy makers, the patient, and the physiotherapist. Otherwise, limiting the number of physiotherapy sessions per treatment episode may drastically affect the achievable functional outcomes of physiotherapy treatments.

In this study, it was found that $53 \%$ of the patients surveyed were treated in 9 treatment sessions or less, and $17 \%$ were treated in more than 18 treatment sessions per episode of care. This means that half of the patients themselves had to pay the additional costs of physical therapy treatments above 9 sessions if they did not have additional health insurance.

One of the most remarkable findings of this study was that the number of treatment sessions was strongly related to the characteristics of the physiotherapists providing treatment. In contrast to other studies that have explored the relationship between patient characteristics and the number of treatment sessions without controlling for physiotherapist characteristics, ${ }^{2.11-15}$ this study has shown that the measured patient and clinical variables were of less importance in predicting the number of treatment sessions than expected from the literature. However, this does not mean that patient characteristics are of no importance. For example, one of the variables expected to be of influence was the duration of patient complaints/symptoms. It was expected that chronic complaints would be more difficult to treat, and thus would require more sessions. This expectation was based on the assumption that chronic complaints are usually embedded in a complex number of factors that are difficult to treat. This expectation, however, was not confirmed by this study. The lack of influence of the duration of the complaints on the number of treatment sessions recorded in this study may partly be explained by the way in which chronic conditions (symptoms/diseases) were handled in the study, and by counting all chronic conditions (symptoms/diseases) as a measurement of grading seriousness. 
Table 3. Hierarchical logistic regression results of the included bivariately associated variables associated with the probability of being treated within 9 sessions (9-sessions model) or within 18 sessions (18-sessions model) per physiotherapy treatment episode: regression coefficients (B) and standard errors (SE)

\begin{tabular}{|c|c|c|}
\hline & $\begin{array}{l}\text { 9-sessions model } \\
\text { B (SE) }\end{array}$ & $\begin{array}{l}\text { 18-sessions model } \\
\text { B (SE) }\end{array}$ \\
\hline \multicolumn{3}{|l|}{ Level 1: Patient characteristics } \\
\hline Gender (male) & $.0 .45(0.32)$ & \\
\hline Age $(y r)$ & $1.05(0.35) * *$ & \\
\hline Health insurance (private) & $-0.88(0.38) *$ & \\
\hline Prior physiotherapy (yes) & $-0.85(0.35) \cdots$ & \\
\hline Prior medical therapy (yes) & $1.04(0.40) \cdots$ & \\
\hline Joint (yes) & & $2.17(1.06)^{*}$ \\
\hline Back (L02; yes) & $0.20(0.15)$ & $1.14(0.46) *$ \\
\hline Shoulder (L08; yes) & & $0.89(0.59)$ \\
\hline \multicolumn{3}{|l|}{ Impairment in: } \\
\hline pain following movement & & $1.55(0.84)$ \\
\hline range of motion (decreased) & $0.63(0.34)$ & \\
\hline muscle tone (decreased) & $-0.67(0.55)$ & \\
\hline in body posture & $0.76(0.48)$ & $0.42(0.54)$ \\
\hline in joint position & $0.56(0.39)$ & \\
\hline edema/swelling & $-1.00(0.49) *$ & $-2.02(1.12)$ \\
\hline number of impairments & & $0.96(0.49)$ \\
\hline \multicolumn{3}{|l|}{ Disability in: } \\
\hline changing postures & $0.59(0.38)$ & \\
\hline carrying & $0.72(0.40)$ & \\
\hline reaching & & $0.88(0.49)$ \\
\hline handling objects & & $0.85(0.53)$ \\
\hline bending over & $0.72(0.44)$ & \\
\hline number of disabilities & $0.94(0.48)$ & \\
\hline \multicolumn{3}{|c|}{$\begin{array}{l}\text { Level 2: physiotherapist and practice } \\
\text { characteristics }\end{array}$} \\
\hline Age $(<45$ years $)$ & $-2.00(1.02) *$ & \\
\hline Pediatrics & $3.09(1.19) *$ & $1.43(0.81)$ \\
\hline Sports physiotherapy & & $1.64(0.88)$ \\
\hline Manual therapy & $-1.25(0.47) *$ & $-1.30(0.50) \cdots$ \\
\hline Womens' health & $1.71(0.87)^{*}$ & $1.82(0.72) *$ \\
\hline Cooperation (excellent) & & $-2.53(0.77)^{\infty}$ \\
\hline No. of partners (single-handed) & $-0.93(0.35) \cdots$ & \\
\hline
\end{tabular}

$* p<0.05(t>1.96) ; * * p<0.01 \quad(t>2.576) ; * * p<0.001 \quad(t>3.29)$

This is not necessarily the case. It is also possible that the number of sessions per treatment episode was not related to the duration of the complaints, but rather to the length of the treatment episode as a result of a better (more efficient) pacing of treatment sessions. Similar assumptions also apply to patients who suffer from psychosocial 
complaints in addition to physical conditions. Physiotherapy focuses primarily on the treatment of physical symptoms. Ignoring psychosocial factors may well lead to less effective and/or more treatment sessions. It must be noted that a number of psychosocial factors that are assumed to be predictive as to chronic disability (such as coping behavior, locus of control, and fear/avoidance belief) have not been considered in this study. ${ }^{48-52}$ The literature shows strong indications that the above-mentioned psychosocial factors influence the process of disablement ${ }^{17,28,36,48,49.53,54}$ and the extent of care. ${ }^{11,14,15,33,34}$ It is recommended that future research, address the effect of these personal factors on treatment.

On theoretical grounds, it was expected that the nature of the disease/disorder would affect the number of sessions required. The nature of the disease/disorder may be defined in medical as well as in physiotherapeutic terms. However, the medical referral diagnosis does not provide the physiotherapist with sufficient information with regard to treatment choices. ${ }^{17,55-57}$

The assessment of (functional) health status, for example, in terms of impairments and disabilities, and of impeding or promoting factors affecting prognosis, may direct or shape the choice of physiotherapeutic treatment. ${ }^{1-11.17 .31}$

This study demonstrates that, while there is some relationship between the number of impairments and disabilities and the probability of a patient's being treated within 9 or 18 sessions per treatment episode, the addition of the physiotherapist variables all but eliminates the influence of the impairments and disabilities on the number of treatment sessions provided.

Other factors of particular concern to delivery of physiotherapeutic services are: the increasing prevalence of disorders of the locomotor system; the continuing increase in patient help-seeking behavior; and an increase in the consumption of primary care services. ${ }^{8.9 .58-60}$ The challenge for the physiotherapy profession is to optimize functional status for persons with a higher prevalence of physically, emotionally, and socially disabling musculoskeletal conditions within acceptable costs, and also to neutralize unexplained clinical variation among physiotherapists, and unnecessary heterogeneity in the processes used to care for patients. ${ }^{8.16-18}$ The finding that the variation in the number of sessions per treatment episode reflects differences in physiotherapist and practice characteristics is a plea for the development of clinical practice guidelines. These findings seem to support the hypothesis that physiotherapists" uncertainty about the effectiveness of specific treatments in reaching desired outcomes may be a factor in their development of a style of practice that is influenced by many idiosyncratic factors. ${ }^{8,14,15,46}$

It is recommended that the results of this study be interpreted with caution; the study population was limited, and consisted of patients with a broad range of musculoskeletal disorders and different levels of functioning, which precluded meaningful subgroup analysis by specific condition. 
Table 4. Hierarchical logistic regression analysis of the significant related variables final models): odds ratio's (OR) and $95 \%$ confidence intervals $(\mathrm{Cl})$

\begin{tabular}{|c|c|c|}
\hline & OR $(95 \% \mathrm{CI})$ & p-value \\
\hline \multicolumn{3}{|l|}{ 9-sessions model } \\
\hline \multicolumn{3}{|l|}{ Level 1: patient characteristics } \\
\hline Age of patient (yrs) & $2.86(1.44-5.64)$ & $<0.05$ \\
\hline \multicolumn{3}{|l|}{$\begin{array}{l}\text { Level 2: physiotherapist and practice } \\
\text { characteristics }\end{array}$} \\
\hline Age of physiotherapist ( $<45$ years) & $0.11(0.01-0.88)$ & $<0.05$ \\
\hline Pediatrics (yes) & $26.84(2.61-275)$ & $<0.01$ \\
\hline Manual therapy (yes) & $0.30(0.12-0.74)$ & $<0.01$ \\
\hline No, of partners (single-handed) & $0.32(0.16-0.63)$ & $<0.01$ \\
\hline \multicolumn{3}{|l|}{ 18-sessions model } \\
\hline \multicolumn{3}{|l|}{ Level I: Patient characteristics } \\
\hline Joint (yes) & $5.93(1.02-34.46)$ & $<0.05$ \\
\hline Back (L02) (yes) & $5.36(1.73-68.03)$ & $<0.01$ \\
\hline Pain following movement (yes) & $1.41(1.06-15.80)$ & $<0.05$ \\
\hline \multicolumn{3}{|l|}{$\begin{array}{l}\text { Level 2: physiotherapist and practice } \\
\text { characteristics }\end{array}$} \\
\hline Manual therapy (yes) & $0.33(1.06-15.80)$ & $<0.01$ \\
\hline Cooperation (excellent) & $0.05(0.15 \cdot 0.72)$ & $<0.001$ \\
\hline
\end{tabular}

${ }^{*} p<0.05(t>1.96) ; * * p<0.01 \quad(t>2.576) ; * * * p<0.001(t>3.29)$

\section{Conclusion}

To our knowledge, this is the first study to note the impact of physiotherapist and practice setting characteristics on the extent of physiotherapy services. This finding, together with the current knowledge about psychosocial factors affecting health outcomes, such as chronic pain behavior, and psycho-educative strategies, must be employed in developing systems for effective and uniform musculoskeletal disease management. This requires ongoing training of physiotherapists to gain new insights into evidence-based treatment strategies, the importance of coping behavior, and methods of patient education that enhance adherence to treatment and change negative behavior patterns.

The physiotherapist's personal and professional characteristics such as age, specialty or communicative skills are found to influence the number of sessions per treatment episode. This may be the result of their working style, clinical reasoning processes, or attitude toward patient care. This important finding needs to be studied in further research including other factors such as the physiotherapist's behavior, treatment preferences, and practice style; such further study could reduce clinical variation and contribute to more efficient patient care. 


\section{References}

1. Kerssens JJ, Groenewegen PP. Referrals to physiotherapy: The relation between the number of referrals, the indication for referral and the inclination to refer. Social Science \& Medicine 1990;30:797-804.

2. Kerssens JJ, Curfs EChr. Extramurale fysiotherapie (PhD dissertation). Netherlands Institute for primary health care (Nivel): Utrecht: Nivel, 1993.

3. Dekker J, Van Baar ME, Curfs EChr, Kerssens J.. Diagnosis and treatment in physical therapy; an investigation of their relationship. Physical Therapy 1993;73:568-580.

4. Dekker J, van Baar ME (eds). Beleidsgericht Evaluatie- en Effectonderzoek Extramurale Fysiotherapie 1989-1992. Nederlands instituut voor onderzoek van de gezondheidszorg (Nivel). Utrecht: Nivel, 1995.

5. Van der Valk R, Dekker J, Boschman M. Basisgegevens extramurale fysiotherapie 1989-1992. Gegevens uit het project "Beleidsgericht Evaluatic- en Effectonderzoek Fysiotherapie (BEEF)". Nederlands instituut voor onderzoek van de gezondheidszorg (Nivel). Utrecht: Nivel, 1995.

6. Jette AM, Smith K, Haley SM, Davids KD. Physical therapy episodes of care for patients with low back pain. Physical Therapy 1994:74:101-115.

7. Jette AM, Jette DU. Physical therapy and health outcomes in patients with spinal impairments. Physical Therapy 1996;76:930-941.

8. Jette DU, Jette AM. Professional uncertainty and treatment choices by physical therapists. Archives of Physical Medicine and Rehabilitation 1997:78:1346-1351.

9. Jette AM, Delitto A. Physical therapy treatment choices for musculoskeletal impairments. Physical Therapy 1997:77:145-154.

10. Uunk WJG, Groenewegen PP, Dekker I. Verwijzingen van huisartsen naar fysiotherapeuten: een verklaring en analyse van verschillen tussen huisartsen. Mens en Maatschappij 1992;67:389-411.

11. Zuijderduin W. Dekker J, Abrahamse H. Determinanten van de omvang van de behandeling in de extramurale fysiotherapie. Tijdschrift voor Sociale Gezondheidszorg 1995;73:274-281.

12. Van Ravensberg CD, Van Klaveren AAJ, Wams HWA, Oostendorp RAB, Elvers JWH. Hendriks HJM. Variabelen in samenhang met aantal behandelingen fysiotherapie: analyse FON-PPP-gegevens. Nederlands Paramedisch Instituut (NPi). Amersfoort: NPi, 1995.

13. Roebroeck ME, Hutten JBF, Kerssens JJ, Dekker J. De omvang van de fysiotherapeutische behandeling naar verschillende patiëntencategorieên. Nederlands instituut voor onderzoek van de gezondheidszorg (Nivel), Utrecht: Nivel, 1995.

14. Mielenz TJ, Carey TS, Dyrek DA, Harris BA, Garrett JM, Darter JD. Physical therapy utilization by patients with acute low back pain. Physical Therapy 1997;77:1040-1051.

15. MeCarthy ML, Ewashko T, MacKenzie EJ. Determinants of use of outpatient rehabilitation services following upper extremity injury, Journal of Hand Therapy 1998;11:32-38.

16. Swanson G. Use of outcome reports: justifying the need for physical therapy services. Orthopaedic Physical Therapy Clinics of North America 1995;4:253-268.

17. Hendriks HJM, Oostendorp RAB, Bernards ATM, Van Ravensberg CD, Heerkens YF. Nelson RM. The diagnostic process and indication for physiotherapy: a prerequisite for treatment and outcome evaluation. Physical Therapy Reviews 2000:5:29-47.

18. Hendriks HJM, Bekkering GE, Van Ettekoven H, Brandsma JW, Van der Wees Ph, De Bie RA. Development and implementation of national practice guidelines: a prospect for continuous quality improvement in physiotherapy. An introduction to the method of guideline development (Part I). Physiotherapy 2000 (in press).

19. Beckerman H, Bouter LM, Van der Heijden GJMG, De Bie RA, Koes BW. Efficacy of physiotherapy for musculoskeletal disorders: what can we learn from research? British Joumal of General Practice 1993:43:73-7.

20. Newman DJ. Physiotherapy for best effect. Physiotherapy 1997;83:5-11.

21. Higgs J. Titchen A, Research and Knowledge. Physiotherapy 1998:84:72-80.

22. Battié MC. Cherkin DC, Dunn R, Ciol MA, Wheeler KJ. Managing low back pain: attitude and treatment preferences of physical therapists. Physical Therapy 1994:74:219-226.

23. Hart E, Pinkston D, Ritchey FJ, Knowles CJ. Relationship of professional involvement to clinical behaviors of physical therapists. Physical Therapy 1990:70:179-87. 
24 Uili RM, Wood R. The effect of third-party payers on the clinical decision making of physical therapists. Social Science \& Medicine 1995:40:873-879.

25. Hendriks HJM, Wagner C, Dekker J, Brandsma JW. Evaluatie van het consultatief fysiotherapeutisch onderzoek in de eerste lijn. Resultaten van een veldexperiment. Nederlands instituut voor onderzoek van de gezondheidszorg (Nivel) \& Nederlands Paramedisch Instituut (NPi). Nivel/NPi: Utrecht, 1994.

26. Hendriks HJM, Wagner C, Brandsma JW, Oostendorp RAB, Dekker J. Experiences with physiotherapist's consultation. Results of a feasibility study. Physiotherapy Theory and Practice 1996:12:211-20.

27. Hendriks HJM, Kerssens J, Dekker J, Oostendorp RAB, Van der Zee J, Nelson RM. Physical therapist consultation in general practice: its use and impact on the process of care. Physical Therapy (accepted).

28. Hendriks HJM, Kerssens JJ, Elvers JWH, Dekker J, Van der Zee J, Oostendorp RAB. Patterns of utilization and efficiency of care following a one-time physiotherapist's consultation in general practice. Physiotherapy Theory and Practice (accepted)

29. Hulka B, Wheat JR. Pattems of utilization: the patient perspective. Medical Care 1985;23:438-460.

30. Akpala CO, Curran AP, Simpson J. Physiotherapy in general practice: patterns of utilization. Public Health 1988; ten:263-68.

31. Oostendorp RAB, Van Ravensberg CD, Wams HWA, Heerkens YF, Hendriks HJM Fysiotherapie, wat omvat het? Bijblijven 1996;12:5-17.

32. Yoshida KK, Allison KR. Sociodemographic and health-related characteristics of Ontarians making contact with physical therapists: analysis of the 1990 Ontario health survey. Physiotherapy Canada 1997:49:214-221.

33. Roach KE, Ally D, Finnerty B, Watkins D, Litwin BA, Janz-Hoover B, Watson T, Curtis KA. The relationship between duration of physical therapy services in the acute care setring and change in functional status in patients with lower-extremity orthopedic problems. Physical Therapy 1998;78:19-24.

34. Freburger JK. An analysis of the relationship between the utilization of physical therapy services and outcomes for patients with acute stroke. Physical' Therapy 1999;79:906-918.

35. WHO (World Health Organization). International Classification of Impairments, Disabilities, and Handicaps (ICIDH): a manual of classification relating to the consequences of disease. WHO: Geneva, 1980 ,

36. WHO (World Health Organization). International Classification of Impairments, Activities and Participation: a manual of dimensions of disablement and functioning (ICIDH-2). WHO: Geneva, 1997.

37. Hendriks HJM, Brandsma JW, Heerkens YF, Oostendorp RAB, Nelson RN. Intraobserver and interobserver reliability of assessments of impairments and disabilities. Physical Therapy 1997;77:1097. 1106.

38. Lamberts H, Wood M. International Classification of Primary Care (ICPC). Oxford: Oxford University Press, 1987.

39. Van der Velden J, De Bakker DH, Claessens AAMC, Schellevis FG. Nationale studie naar ziekten en verrichtingen in de huisartsenpraktijk. Basisrapport: Morbiditeit in de huisartsenpraktijk. Netherlands institute of primary health care (Nivel). Utrecht: Nivel, 1991.

40. Bryk AS, Raudenbusch SW. Hierarchical Linear Models: applications and data management methods. Newbury Park: Sage publications, 1992.

41. Goldstein H. Multilevel statistical models. 2nd ed. New York, NY: Halsted Press, 1995.

42. Patterson L, Goldstein H. New statistical methods, for analysing social structures: an introduction to multilevel models. British Educational Rescarch Journal 1991:17:387-393.

43. Jones K. Moon G. Multilevell assessment of immunisation uptake as a performance measure in general practice. British Medical Journal 1991;303:28-31.

44. Bensing JM, Kerssens JJ, Van der Pasch M. Patient-directed gaze as a tool for discovering and handling psychosocial problems in general practice. Joumal of Nonverbal Behavior 1995;19:223-242.

45. Duncan $\mathrm{C}$, Jones $\mathrm{K}$, Moon $\mathrm{G}$. Health-relared behaviour in context: a multilevel modeling approach. Social Science \& Medicine 1996:42:817-830.

46. Kerssens JJ, Sluijs WM, Verhaak PFM, Knibbe HJJ, Hermans IMJ. Back care instructions in physical therapy: a trend analysis of individualized back care programs. Physical Therapy 1999;79:286-295.

47. Rasbach J, Woodhouse G. MLA Command reference. London, England: Institute of Education, University of London, 1995 
48. Verbrugge LM, Jette AM 1994 The disablement process. Social Science \& Medicine 38:1-14

49. Johnston M. Models of disability. Physiotherapy Theory and Practice 1996;12:131-141.

50. Waddell G. The Back Pain Revolution. Churchill Livinstone: Edingburgh, 1998.

51. Vlaeyen JWS, Kole-Snijders AMJ, Boeren RGB, Van Eek H. Fear of movement / (re)injury in low back pain and its relation to behavioral performance. Pain 1995:62:363-372.

52. Watson PJ. Psychosocial assessment. The emergence of a new fashion, or a new tool in physiotherapy for musculoskeletal pain? Physiotherapy 1999;85:530-535.

53. Jette D. Manago D, Medved E, Nickerson A, Warzycha T, Bourgeois MC. The disablement process in patients with pulmonary disease. Physical Therapy 1997:77:385-394.

54. Main CJ, Watson PJ. Screening for patients at risk of developing chronic incapacity. Journal of Occupational Rehabilitation 1995:5:207-217.

55. Sahrmann SA. Diagnosis and classification by the physical therapist - a prerequisite for treatment: a special communication. Phys Ther 1988;68:1703-1706.

56. Sahrmann SA. Moving precisely? Or taking the path of least resistance? Phys Ther 1998;78:1208-1218.

57. Rose SJ. Physical therapy diagnosis: role and function. Physical Therapy 1989:69:535-537.

58. RIVM (Rijksinstituut voor Volksgezondheid en Milieu). Volksgezondheidtoekomst-verkenningen 1997. Effecten van zorg. Elsevier / De Tijdstroom: Bilthoven, 1997.

59. Lubeck DP. The economic impact of arthritis. Arthritis Care Res 1995;8:304-310.

60. Van Baar M. Effectiveness of exercise therapy in osteoarthritis of the hip or knee [PhD Thesis]. Utrecht: Nederlands Instituut voor onderzoek van de gezondheidszorg (Nivel), 1998. 


\section{PART IV}

\section{Discussion \& Summary}




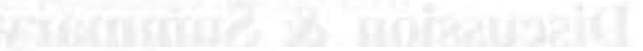




\section{General Discussion}

In this final chapter the main findings of the observational study with respect to the feasibility of a one-time physiotherapist's consultation in general practice are discussed. After a brief introduction on the background and on the rationale of the study, the design of the observational study and the answers to our research questions are critically reviewed. Several methodological, pragmatic, and ethical aspects of this study, which are not fully addressed in the foregoing chapters are highlighted. Furthermore, the implications of the study results for the profession related to current health care reform and future research are considered. Subsequently, guidelines for the process of a one-time consultation and specific recommendations for a successful implementation in general practice are proposed.

Current health care reform of national health care services, the physiotherapy profession included, places great emphasis on quality assurance and integrated (or managed) care, ${ }^{\text {, }}$. focussing on the individual needs and demands of the patient. ${ }^{6}$ This highlights the need for evidence-based physiotherapy practice, effiency and integration of care and interdisciplinary cooperation. ${ }^{7.9}$ However, to achieve this it is of vital importance to gain insight into each other's working methods and therapeutical possibilities, to improve communication and cooperation between the various health care providers (i.e., the GP and the physiotherapist) and to define tasks and responsibilities. ${ }^{7-11}$ In primary care the physiotherapists are important collaborating partners of the general practitioners (GPs) when managing patients with, in particular, disorders of the locomotor system. ${ }^{12.16}$ Research has shown that there are several problems concerning the cooperation between general practitioners and physiotherapists. ${ }^{7.14,17-21}$ These bottlenecks refer to differences in patient populations and to the different ways in which patients are evaluated and treated by these professionals. But also poor communication, ${ }^{17.22}$ uncertainty about the indications for referra! ! $!^{14.21 .24}$ and doubts about the efficacy of physiotherapy play a role. . $10.14,24.28$ it was hypothesized that the implementation of a (one-time) physiotherapist's consultation might improve interdisciplinary communication and the image of the profession and utilization of physiotherapy care. ${ }^{10,14,21,29}$

This thesis builds on the results of previous primary care innovation projects setting out to improve the quality of health care: methodical conduct of the process of physiotherapy practice $24,26,29 \cdot 34$ and clinical reasoning, ${ }^{24.26,35-37}$ professional attitudes and the organization of professional practice. Aspects of quality directly related to a one-time physiotherapist's consultation refer to setting adequate indications for physiotherapy based on a sound 
rationale, and to a critical assessment by the individual physiotherapist of his/her own expertise (knowledge and abilities), aiming at efficiency of care..$^{10.21}$

In an observational study, we studied the feasibility of a one-time physiotherapist's consultation with respect to the GP and the physiotherapist, which conditions were required and which effects were found.

\section{Observational study}

Of great importance in the study design was the testing of the process and the outcome of physiotherapist's consultation in a representative, rather than a select, highly motivated, group of GPs and physiotherapists. Hence, it was critical to easily incorporate the process of physiotherapist's consultation into the daily practice of both the GPs and physiotherapists, so as not to disturb the daily work situation. Also, the experimental opportunity of a one-time physiotherapist's consultation needed to fit into existing usual modes of cooperation between GPs and physiotherapists. The main outcome measures of the study were focussed on the opinions of GPs concerning the opportunity to refer to physiotherapists for a one-time consultation, and the extent to which the process and outcome of physiotherapist's consuitation met with the needs and expectations of both the GPs and physiotherapists.

For these reasons a pragmatic observational study was conducted to evaluate the effects of a one-time physiotherapist's consultation. In 59 pairs of general practitioners and physiotherapists, the GP was offered the opportunity to refer for a one-time physiotherapisi's consultation. The GP and the physiotherapists used request and report forms which were developed at an earlier stage and in which the proces of the one-time consultation was set out. The willingness to participate in the study was very high for both groups of GPs and physiotherapists, $74 \%$ and $82 \%$ respectively. Description of the personal and practice characteristics of the GPs showed that they were representative for the general professional population. As far as the physiotherapists were concerned it seems that some selection bias has occurred. The participating therapists had longer professional experience and those working in a group-practice were over-represented compared to the national reference data. However, the physiotherapists were representative when considering personal characteristics such as age, gender, years after graduation and postgraduate training. Generally speaking, the general practitioners and physiotherapists were satisfied with the existing cooperation. From the written interviews, taken prior to the start of the study, it appeared that one third of the GPs already referred patients occasionally for a one-time visit to the physiotherapist for an advice or to ask whether there was an indication for physiotherapy. This finding is also supported by Kerssens $\&$ Curfs $^{14}$ and Hendriks et al. ${ }^{21}$

It should be noted that physiotherapists with relatively little experience ( $0-4$ year) declined to participate more often, which influences the generalization of the results. 
Research data was collected from the consultation request and report forms, from questionnaires amongst GPs and physiotherapists at the beginning (inventory) and at the end of the study period (evaluation) and from health insurance data on the number of referrals to physiotherapists. Cesar and Mensendieck exercise therapists, and medical specialists (orthopaedics, rheumatology, neurology and rehabilitation). These referral data refer to the period during which consultations could be requested and the same period in the previous year. When a patient was referred for physiotherapy treatment, the number of sessions, the duration of the treatment episode and the outcome of the treatment was registered on a form which was specifically designed for the purpose.

\section{Main Results}

\section{Number of consultation requests}

During a 7-month observational study, 352 patients were referred for a one-time physiotherapist's consultation by 53 of the 59 GPs. The mean number of consultation requests was 6 (range $=0-20$ ). Referral rates for GPs vary widely even among GPs working in the same environment. ${ }^{14.21 .38}$ This study showed considerable variation among GPs in the way they make use of physiotherapist's consultation. ${ }^{39}$ The rate of referrals for consultation in this study was low compared with the documented rate of referrals for treatment ( 5 vs 114 referrals per GP for every 1000 patients per year) or compared with the feasibility study (12 per 1000 referrals) ${ }^{29}$ but seems to be comparable with an, in principle, one-time consultation of a medical specialist. ${ }^{40.4 !}$ The reasons for consultation most mentioned were: information on diagnosis and functional (health) status (26\%), indication for physiotherapy treatment $(29 \%)$, or both $(45 \%)$. Additional reasons were: a second opinion from a physiotherapists' perspective (27\%), to support the intended plan of care of the GP (16\%) and to prevent referral to a medical specialist (13\%).

It has been investigated which factors relate to the number of consultation requests. Patients with complaints lasting less than 13 weeks, and patients from GP practices with larger list sizes were referred less often for a one-time consultation.

The lower referral rate of one-time consultations for patients with acute complaints may be related to the wait-and-see policy of many GPs and the expected course of normal recovery (natural history). If the course of recovery was delayed, the potential for physiotherapy consultation to prevent chronicity or disablement increased.

The literature shows that the variation in referral rates may be explained to a large extent by the nature of the disorder. ${ }^{14.38 .4247}$ In particular, the extent to which the disorder is disabling (in the GP's perception) appears to relate to the patterns of referral by physicians to physiotherapists.

The relevance of list size (number of patients) may indicate the influence of increased workload affecting the GPs' behaviour. The research literature on the influence of list size is not unequivocal. The review by Gloerich \& van der Zee ${ }^{48}$ shows fewer referrals per 
physician contact in smaller practices. In larger practices however, the number of contacts per patient may be lower, but the number of referrals per contact increases. It is concluded that the influence of list size on the referral figures is determined by the number of contacts with the GP.

The referral rate for a one-time physiotherapist's consultation by GPs in rural areas was substantially lower than in urban areas and is in concordance with the literature about the influence of referral rates to medical specialists by degree of urbanization of the practice location. ${ }^{49}$ In other words, the higher the degree of urbanization, the higher the rate of referrals to medical specialists and physiotherapists. This finding is confirmed by the research literature. ${ }^{14.21 .39 .48}$ It should be noted that GPs with low referral rates for physiotherapy treatment were under-represented. However, additional analysis between low (lower quartile) and high referral rates for physiotherapy treatment (upper quartile) did not show a significant difference in the frequency of use of physiotherapist's consultation. It appears that GPs exhibit wide individual variations, which can be partly explained by chance, and partly by context and individual approaches to health care.

Another point of interest is the finding that patient profiles referred for a one-time consultation differed from historical records of patients referred for physiotherapy treatment: ${ }^{33.34}$ Most frequently, patients with disorders of the locomotor system were referred for a one-time consultation. Frequent occurring indications for a consultation request were complaints of the knees, backache and 'other pains' in the legs. In general, patients referred for a consultation were younger, more educated and they had more longer term complaints than patients who had been referred by the general practitioner for physiotherapy treatment. Physiotherapist's consultation was hardly used for patients with short term complaints. Clearly, the GP does not feel the need for consultation in patients with acute problems.

In conclusion, GPs actively take the opportunity of a one-time consultation if this option is explicitly on offer. The composition of the group of patients referred for consultation differs from the group of patients referred by the physician for physiotherapy treatment.

\section{Opinion on the outcome of consultation}

The opinion of the GP on the outcome and process of consultation was evaluated on the level of each consultation and on the GP level by a questionniare at the conclusion of the study. In $64 \%$ of the consultations the GP found that the consultation request had been fully answered, in $30 \%$ sufficiently and in $6 \%$ insufficiently or averagely. Thus, although considerable variation was found among the GP referrals in general, the group was satisfied with the process and outcome of consultation. This was especially true of the GPs who, prior to the study, reported that they were not fully knowledgeable about the role of physiotherapy and the diagnostic capabilities of physiotherapists. Interestingly, the GPs who indicated that their cooperation with physiotherapists was not ideal prior to the study, stated more often that they were completely satisfied with the physiotherapist's consultation and the relevance of the information for directing treatment. In general, the GPs were more satisfied when they had consulted more experienced and skilled 
physiotherapists (number of postgraduate educational courses or training and manual therapy). In this respect, it should be noted that physiotherapists with relatively little experience more often declined to participate, which is of influence on the generalization of these results.

For the purpose of the analysis, the satisfaction measure (opinion on the outcome of consultation) was dichotomized into high satisfaction (excellent) and low satisfaction (substantial, fair, slight, poor). This was because of the possibility that respondents would opt for the "substantial" option as a way to avoid expressing very positive (rating of excellent) or very negative (rating of slight or poor) opinions on the result of the consultation request. There is evidence that people are reluctant to express negative perceptions and to give socially desirable answers. ${ }^{39.50-52}$

In the questionnaire at the end of the study, $45 \%$ of the physicians stated that the consultation had always or often been useful in deciding on management, $30 \%$ stated that this had been regularly the case and $25 \%$ said that this had hardly ever been the case. In the same questionnaire $94 \%$ of GPs stated that the conclusions and recommendations made by the physiotherapist were always, or often, sufficiently well-founded.

With respect to the feasibility of a one-time physiotherapist's consultation in general practice, $86 \%$ of the GPs indicated that the consultation (including the requesting, the evaluation of the report, and possibly seeing the patient again) could easily be fitted into their daily practice. The consultation request forms were deemed suitable by nearly all GPs for providing insight to the physiotherapist into the patient's problems and into the actual management policy. Regarding the future use of a one-time physiotherapist's consultation, two out of three GPs stated that in the future they would wish to continue using this opportunity.

In conclusion, GPs are, in general, positive about the outcome and the process of a one-time physiotherapist's consultation and, in most cases, acted upon the physiotherapist's advice. The GP's consultation request was better answered by more experienced and/or more educated physiotherapists. This conclusion is based on the following findings: the opinion held by the GP of the answers to the consultation request was more positive towards physiotherapists who were experienced in one-time consultations, towards physiotherapists who had followed more follow-up and refresher courses, and towards physiotherapists who specialized in manual therapy.

\section{General practitioners' management policy after consultation}

In $11 \%$ of the patients the GPs attended or treated the patient themselves. In $15 \%$ of cases the GP referred the patient to a medical specialist. In $68 \%$ of cases the patient was referred to a physiotherapist and in some cases to an exercise therapist or podotherapist. In $89 \%$ of the cases the GP acted upon the advice from the physiotherapist. When this policy is compared to a fictitious policy (the policy the GP would have chosen had there not been the opportunity of a one-time physiotherapist's consultation), it appears that in more than $50 \%$ of the cases their management policy has been changed. 
There was a substantial reduction in the number of referrals to medical specialists. From the physiotherapists's perspective, there was no indication for physiotherapy in $30 \%$ of the cases and in $56 \%$ of the cases a referral to medical specialists was prevented. These findings suggest substitution of general care rather than referral to medical specialists as a result of the physiotherapist's consultation. However, careful interpretation of these findings is necessary because of the uncontrolled nature of the study.

We also studied which factors related to changes in referral policy (before [fictitious] and after [factual] comparison). We found that a change in GPs intended treatment policy was negatively related to age (lower age groups) and level of education (low) in the patient group, and positively related to the opinion of the GP regarding the outcome of the consultation and his or her frequency of communication with the physiotherapists. Although the opinion of the GP on the outcome of consultation will not provide complete insight into variations in patient demand, it is possibly the most important key variable in relation to their treatment decision.

In conclusion, GPs deemed a one-time physiotherapist's consultation useful for the determination of their policy. Physiotherapist's consultation clearly leads to more appropriate care on the part of the GP, the medical specialist and the physiotherapist. Or rather to an appropriate referral from the perspective of the physiotherapist.

\section{Impact on health insurance referral figures}

No significant changes were found in the health insurance referral figures from GPs to physiotherapists, medica! specialists (orthopaedics, neurology, rheumatology and rehabilitation) or other allied health professionals.

However, when comparing the GP's fictitious management policy to the factual policy it was found that the number of referrals to physiotherapists increases, and the number of referrals to medical specialists decreases. These data suggest that GPs patterns of referral do change as a result of a one-time consultation, but these changes are too small to be demonstrable in referral figures. An analysis of health insurance referral figures shows a similar trend, but the differences are not statistically significant. The most important reasons for this are (1) the enormous variation in referral figures between GPs, so possible changes as a result of a one-time physiotherapist's consultation are difficult to prove, and (2) fewer referrals than expected for a consultation (insufficient power for the study).

By using data about the GP's fictitious policy compared to the factuall policy (besides health insurance figures) resulting from physiotherapist's consultation, the large differences amongsı GiPs have been more or less circumvented and a description has been produced of the more subtle changes in referring.

In conclusion, GPs chose a different management policy after consultation than they would have done had the opportunity for consultation not arisen. Because of the study design, the enormous variation in referral figures to physiotherapy and medical specialists, and by lack of power, it was. impossible to demonstrate changes in health. insurance referral figures. 


\section{Impact on utilization of physiotherapy services}

The findings of the study suggest that the probability of being treated by a physiotherapist after a one-time consultation increased with low education, long-term functional complaints, psychosocial problems, prior physiotherapy, and medical diagnostic testing for the same complaint in the past twelve months.

The finding that patients who received physiotherapy previously were more likely to be treated by a physiotherapists than those who did not receive physiotherapy treatment, possibly results from the fact that these patients as well as the GP were satisfied with their improvement or recovery of their condition and the care they had received.

Furthermore, the study indicated that patients with a decrease in physical functioning, measured in terms and number of impairments and disabilities were more likely to be treated by physiotherapists or medical specialists than by the GP themselves. The findings indicate that demographic and functional-status and health-status-related characteristics are important predictors in utilization of physical therapy services.

These findings also lead to the proposition that the more severe the functional problem, the more likely the patient is to be referred for physiotherapy treatment. However, the more severe and/or the more chronic the condition of the patient, the worse the prognosis of early recovery and as a result the more sessions per treatment episode are required.

The overall mean number of treatment sessions of a range of muskuloskeletal disorders in our study was $11.6(\mathrm{sd}=7.8)$ including a one-time consultation. About half of the patients were treated in nine or less treatment sessions and $17 \%$ of the patients were treated in more than 18 treatment sessions per episode of care.

With respect to the opinions on the implementation of the process of a one-time physiotherapist's consultation, practically all physiotherapists (95\%) agreed that the procedure of a one-time consultation as a whole (patient appointment, actual assessment and report within certain time-limits) can be easily incorporated into daily practice. The physiotherapists were positive about the consultation request form: $94 \%$ considered the form suitable for providing insight into the patients' problem and the actual management policy. Almost all physiotherapists $(96 \%)$ felt that they had received sufficient information from the general practitioner to be able to answer the consultation request. Opinions about the clarity of the consultation request were slightly less positive: $77 \%$ of the physiotherapists thought the consultation request by the GP had been clearly stated. The physiotherapists spent, on average, 50 to 70 minutes on the consultation (assessment and report). The majority of physiotherapists spent about 20 to 40 minutes on the actual assessment, and about 10 to 30 minutes on the report.

In conclusion, utilization of physiotherapy services is strongly related with the level of functioning. It should be noted that unequal baseline characteristics could lead to inappropriate conclusions about the effectiveness of physiotherapy when comparisons are made in outcome between different providers. In future studies it is important to examine health status characteristics and its impact on distinct levels of functioning, rather than on the medical diagnosis. Physiotherapists are satisfied with the process of one-time physiotherapist's consultation and the standard forms. 


\section{Determinants of the number of sessions per treatment episode}

Knowledge of the expected number and determinants of the actual number of sessions per treatment episode is extremely relevant for health care policy makers, with regard to the maximum number of treatment sessions per episode of care. Specifically, since the recently introduced remuneration system for physiotherapy was changed to 9 sessions which further limits the number of sessions per time period or by medical diagnosis per indication per year. For patients with a complementary insurance an additional number of nine sessions is reimbursed, resulting in a maximum number of 18 sessions per indication per year. This remuneration system, related to the restricted number of treatment sessions, may drastically affect the utilization related to maximally achievable functional outcome of physiotherapy treatment.

One of the most remarkable findings of this study was that the number of sessions per treatment episode were strongly related with the characteristics of the physiotherapists (age [as a measure of experience], specialty and communicative skills) and their practice setting (number of professional partners). In contrast with other studies that explored the relationship between patient variables and number of treatment sessions without controlling for physiotherapists characteristics, ${ }^{42,44,46,47.53}$ this study showed that the measured patient variables are of less importance in predicting the number of sessions than expected from the literature. ${ }^{45}$

For example, one of the variables expected to be of influence was the duration of the complaints. This expectation could not be confirmed in the study. The lack of influence of the duration of the complaints on the number of treatment sessions might, however, partly be explained by the way in which chronic conditions are handled by counting all chronic diseases as a measurement of grading severity. Another explanation could be that not the number of sessions per treatment episode was related with the duration of the complaints, but the duration or length of the treatment episode. Within the four broad categories of the duration of the complaints, not the mean number of treatment sessions but the mean duration of treatment (in weeks) was affected. Probably it is also important to study the duration of the treatment episode related with the spread of sessions per treatment episode, functional outcome and to control for the physiotherapists characteristics in future studies.

In conclusion, the challenge for the physiotherapy profession is to optimize functional. status for persons with higher prevalent physically, emotionally and socially disabling muskuloskeletal conditions for acceptable costs and also to neutralize unexplained clinical variation between physiotherapists and unnecessary heterogenity in the processes used to care for patients. Physiotherapist's personal and professional characteristics such as age. specialty or communicative skills are found to be of influence on the number of sessions per treatment episode. This might be the result of their working style, process of care and attitude to care for their patients. This important finding needs to be studied in futher research because it might reduce clinical variation contributing to more efficient care. 


\section{Limitations of the Study}

\section{Observational Study}

Although the results of this non-controlled study are promising, this study has several of the usual limitations of a real-world observational study.

The first limitation is that the study is not designed as a randomized controlled comparison. In designing the study, a true-experimental rather than quasi-experimental design was considered. From a methodological perspective, a true-experimental design was preferrable. However, this was decided against on the following grounds. In a trueexperimental set-up, a relatively large number of GPs would have been required to participate both in the experimental and in the control group since large variation exists among GPs in the number of patients they refer to medical specialists ${ }^{54.58}$ or physiotherapists. ${ }^{14.16 .21 .38}$ A possible shift in referral figures resulting from a one-time physiotherapist's consultation would only have become apparent if a large number of GPs had been involved in the study. A power analysis showed that in a design using two groups of GPs, in order to make apparent the effect of the number of referrals to physiotherapists and medical specialists, the number of GPs in the study needed to be almost four times as large ( $\mathrm{n}=220 \mathrm{GPs})$ as in the design finally decided upon $(\mathrm{n}=60$ GPs). So, a study involving two separate groups would have been highly extensive and costly.

To facilitate the research into the effects of a one-time physiotherapist's consultation on the number of referrals by GPs to physiotherapists and medical specialists, registering all GP contacts during the fieid trial would have been desirabie. However, the registration of such a volume of data would have had an adverse effect on the GPs' willingness to participate in the study. For this reason, health insurance figures, among others, were employed, despite their limitation with regard to generalization. Nevertheless, a choice was made to use health insurance figures in order to place the least possible burden on GPs. The number of referrals made by GPs to medical specialists (orthopaedics, rheumatology, neurology, and rehabilitation medicine) and physiotherapists were compared during the experimental, and control period. Analyzing referral figures to all specialists is unnecessary and would have caused a superfluous augmentation of the research. However, the most important argument against admitting data on referrals to other, less relevant medical specialists, is that to do so would obscure any differences in the number of target referrals made during the experimental and control periods.

One problem with the quasi-experimental design of this study is that a trend-shift in the number of referrals might be unjustly ascribed to the introduction of physiotherapist's consultation. It was, in part, possible to anticipate this problem by investigating the context of changes in referrals. Whether the actual use of physiotherapist's consultation was related to changes in referrals to primary or secondary care has been considered. If, for instance, the number of referrals to physiotherapy is related to a reduction in the number of referrals to secondary care, this may indicate that physiotherapist's consultation 
leads to a reduction in the number of referrals to secondary care.

As shown by the comparison between the actual and fictitious referral policy after a onetime physiotherapist's consultation there was a substantial reduction in the number of referrals to medical specialists. This finding suggest substitution of general care rather than referral to medical specialists as a result of the consultation. However, interpretation of these findings should be cautious because of the uncontrolled nature of the study.

To detect significant changes in health insurance referral figures between the experimental and control period, with an expected chance to be referred for physiotherapy treatment or medical specialist after the consultation by a GP of $16 \%$ and $8 \%$, respectively, the minimum estimated number of consultation requests was 800 (with a type I error of 0.05 [iwo-tailed] and a type II error of 0.20) when we assume a difference of interest of at least $20 \%$. However, the total number of consultation requests was less than expected.

Therefore, the achieved power to detect significant differences in referral figures was far from sufficient (eg. $53 \%$ for physiotherapy as a measure of outcome).

\section{Prospective cohort study}

In our second part of the study we examined utilization of physiotherapy services and outcome of patients being treated by a physiotherapists after a one-time physiotherapist's consultation during a follow up of all treatment episodes.

A major threat to the validity of the results of our observational study is the lack of a control group, the amount of drop-outs and losses-to-follow-up. However, the availability of concurrent data from national reference data strengthening the study's results by providing an opportunity for comparison of utilization outcome data from patients referred by GPs for physiotherapy treatment. ${ }^{33,34}$ In the follow up of 243 patients indicated for physiotherapy treatment $19(5.6 \%)$ were lost to follow up because they were being treated by a physiotherapist not participating in the study as recommended by the physiotherapistconsultant. In the follow-up of all patients being treated by a physiotherapist each patient was monitored carefully during the treatment episode. None of the 224 patients being treated by a physiotherapist participating in the study was lost for follow up. Therefore the results of the study were probably not biased by selective withdrawal.

One limitation was that the functional outcome measures by themselves were crude and greater detail is needed for a more profound understanding of physical therapy service utilization. However, the functional outcome in terms of impairments and disabilities of physical functioning from the physiotherapist's point of view and the subjective recovery on a five-point scale are indicative for reflecting the actual state from the patients ' point of view. The study made use of therapist's self-reports on the effects on improvement rates. Self-report measures are known to be susceptible to bias. However, we also used the patient's self-rated outcome on the global perceived benefit of physiotherapy treatment. The (functional) outcome, measured by both the patient and physiotherapist, are in the same order, so major adverse outcomes would have become known.

The results of the study are also limited by the fact that only the outcomes of physical therapy services were examined. The outcomes of treatment by the other health 
professionals and the long-term results of patients treated by a physiotherapists were not noted. For these reasons one should be cautious in the interpretation of the findings. The multiple comparisons between national reference data and subgroup analysis as well suggest statistically significant findings which may have occurred by chance alone. However, almost all statistical comparisons were in the same direction.

In conclusion, despite the shortcomings of the study the results indicate that a one-time physiotherapist's consultation improves the communication with the GP and leads to more appropriate referral for physiotherapy treatment, better joint care and more satisfying functional outcomes. Specifically, when we consider the group of patients referred for a one-time consultation, in whom the indication of physiotherapy treatment was not, at first, entirely clear to the GP.

\section{Implications}

Considering all findings and conclusions, the question arises as to what the implications may be for the two professions involved, for the patients and, taken into account the changed position of patients, for patient health care. Clearly, there are implications for the present health care system. With a view to the ageing population and the increase in health problems which will probably be the result, ${ }^{2.3 .59 .60}$ the increased costs of health care and the need for more efficiency of health care services ${ }^{24,8,9,11}$ it is generally agreed that extensive changes will have to be made.

Before focussing on the results and the implications, it seems useful to consider the motive for this research. A number of studies, executed in the nineteen-eighties and nineties, came across problems in the cooperation between general practitioners and physiotherapists. ${ }^{10,14,21}$ These bottlenecks related, amongst other things, to differences in patient populations, working methods and goals of treatment.

An inventory amongst GPs revealed that they considered their knowledge about the indication setting for physiotherapy treatment to be insufficient, and almost all thought that they had insufficient knowledge about physiotherapy practice in general. ${ }^{10.14 .21}$ Furthermore, GPs differed in opinion about the need for physiotherapy and referrals for physiotherapy often depended on their personal beliefs and experience.

The onset of evidence-based physiotherapy, which started at the end of the eighties, the numerous developments in structuring and clarifying the profession whilst striving for quality of care, has not made. it easy for physicians and medical specialists to keep abreast of the specific treatment options physiotherapy has to offer. Also, doubts remain with respect to the efficacy and efficiency of physiotherapy. ${ }^{2428}$

Other research showed that the more intensively GPs and physiotherapists cooperate, the more positively they appear to feel about the benefits of physiotherapy. ${ }^{14.20,21}$ Also, physiotherapy appears to become more efficient when the physiotherapist's expertise is employed at an early stage in the contacts between the physician and the patient. ${ }^{10.21,29} \mathrm{GPs}$ 
who work together intensively with physiotherapists appear to refer to secondary care specialists less often. ${ }^{61}$

In practice, it has become clear that the medical diagnosis alone, provides insufficient information on which to base physiotherapy treatment. ${ }^{7,10,14,24,26,30,31,35.37 .62}$ This is because physiotherapy treatment does not primarily focus on the disease/disorder itself, but rather on the consequences of the disease/disorder. These consequences may be subdivided into impairments in function/structure, limitations in activities and restrictions in participation. ${ }^{63,64}$ Physiotherapists have specific expertise at their disposal with which they can, and must, define their own physiotherapist's diagnosis. It was hypothesized that the GP, before deciding on his medical policy (and/or diagnostic procedures) may benefit from consulting a physiotherapist for certain (and by no means all) patients, before deciding to refer for physiotherapy treatment.

\section{Implications related to health care reform}

The implementation of a one-time physiotherapist's consultation may possibly make a contribution to a firm positioning of physiotherapeutical care, and clarify to others what their job can or cannot be.

Considering the fact that this research was also investigated by the health care policy makers of that time, it seems justified to describe the more recent developments in health care. In the in-between years health care has been subjected to a number of changes which were inspired by the necessity to achieve the most efficient care ${ }^{5,8,9.65}$ as well as the need to upkeep and raise the quality of care. ${ }^{2.5}$ The responsibility for the quality of care and the issue of cost containment has subsequently moved from the government to the three parties within the health care services: the patients, the care providers, and the care insurance companies. There are concrete agreements about the ways in which new policies are to be executed, which are set down in the so-called "Leidschendam" agreements ${ }^{4}$ as well as in the 'Meerjaren' agreements.

Ai the laiest Leidschendam meeting it was agreed that the professions develop quality systems in which explicit attention is paid to the coordination of care and to a broad organizational structure. ${ }^{4}$ Also, care providers must have a mutual perception of the nature, content, process, and efficiency of care.

It is obvious that the health care service has problems. The budget is limited in relation to the growing requirements for care, not only caused by the increasing number of old people, but also by patients with more complex health problems. The Council for Public Health and Care (De Raad voor de Volkgezondheid en Zorg) describes the most important bottlenecks as the extreme task differentiation in health care, insufficient task definition amongst care providers and amongst organizations, poor communication and supply of information and an inflexible structure of financing. 2.11 .06

Health care is ready for a reorganization in which a better control of the costs, through higher efficiency, and a central position of the patient, are the most important goals..$^{2-6.60}$ These goals must be met by providing guarantees for the continuity of care,' and by integrating the various processes of care. ${ }^{3.9 .9 .11 .06-89}$ 
It is striking that in these plans for future health care, the allied health professions are mentioned only incidentally. The work by those professionals which is indispensible to many of the chronically ill and to patients with multiple health problems, is not perceived or mentioned.

Another development which deserves more attention in the years to come concerns the possibility of care substitution. It is increasingly suggested that doctors delegate certain tasks to, for instance, allied health professionals. ${ }^{2,3,11,65,60}$ In this connexion the relationship may emphasized which exists between dentists and dental hygienists, eye specialists and orthopticians, rehabilitation specialists and physiotherapists. The possibilities of achieving care substitution are good at the moment because of the threatening shortage of (general) practitioners. However, take-over and/or substitution of tasks must be agreed by all parties, be based on job contents, and be carried out from the perspective of costeffectiveness and optimal patient care. Examples of task substitution could be: the attendance and/or treatment of patients with acute ankle injuries, (stress) urinary incontinence, COPD, osteoarthritis for hip and/or knee and low back pain. For the abovementioned patient-categories, multidisciplinary, as well as monodisciplinary guidelines are available or being developed, ${ }^{20-76}$ For the GP, a one-time physiotherapist's consultation may, for instance, be useful to gain insight into the possibilities of the physiotherapist, into treatment strategies (including the scientific basis) and into possible bottlenecks.

\section{Implications for the professions}

Responsibility for the quality of care is not only a concern for the government. It is also a primary concern for the professionals themselves. It is clear that physiotherapists are important in diagnosing and treating patients with musculoskeletal conditions and that adequate referral for physiotherapy treatment can make a difference in cost-effectiveness. The results of the study support the view that physiotherapist's consultation improves the indication setting, utilization and transparency for physiotherapy treatment, and communication between both professionals. The challenge for the physiotherapists, as the GP as well, is to optimize the functional health status for persons with these highly prevalent physically, emotionally, and socially disabling musculoskeletal conditions.

The Dutch Society of General Practitioners (NHG) has already a limited number of evidence based standards of care concerning the locomotor system, for their management, exercise prescription, utilization of ancilliary services and referral!' The Royal Dutch Physiotherapy Association (KNGF) has also developed evidence based practice guidelines. in which there are some opportunities for the physiotherapists to cooperate and for joint care. ${ }^{7.65 .77 .78}$

The implementation of structured and regular meetings between two or more health care professionals is often hampered by the lack of time, organisational problems, and the present reimbursement system which does not compensate for time invested in communication. The additional benefits of physiotherapist's consultation can not only be expressed quantitatively (number of referrals). Of equal importance is the effect on knowing each other and better communication and cooperation. Research into the cost- 
benefits of communication and cooperation is scarce, and concerns mainly the number of (avoidable) referrals to second line health care. It can be proposed that the savings are higher than the investments that are necessary.

It becomes increasingly difficult for the disciplines in primary health care to offer services independent from other disciplines. Especially in complex situations, for example terminal home care. Health care providers become dependent on each other. It is not yet very common for physiotherapists to participate in multidisciplinary cooperation meetings in primary health care. It is extremely important for the physiotherapists, however, to get involved whenever opportunities arise. Physiotherapy is an essential part of the total Dutch health care system. The opportunity for a referral for a one-time physiotherapist's consultation will contribute to and enhance multidisciplinary cooperation and joint care.

Our study indicates that in situations in which all respect each other's areas of competence and responsibilities, the process of consultation by means of written communication can be expected to be relatively free of problems.

Another important issue is whether a consultancy function for physiotherapists should be reserved for certain specialized, and as such recognized physiotherapists, or if certain other requirements e.g. years of experience, attendance of postgraduate courses should be allowed for a physiotherapist to be consulted. It can be expected that GPs who are not satisfied with the report of the physiotherapist who has been consulted will refer patients for a consultation to another physiotherapist or directly to a physiotherapist-specialist.

The study as described in this thesis concerns solely the consultation between GPs and physiotherapists in general practice. It would certainly be worthwhile looking into the effects of consultations between medical specialists and physiotherapists within and outside the hospital or institutionalised care, and interdisciplinary consultations between physiotherapists and more specific trained, experienced or specialized physiotherapists. This is informally practised but the structure of the health care system in The Netherlands does not allow a formal consultation between colleagues.

In my opinion the implementation of a well structured procedure of a one-time physiotherapist's consultation in the primary care setting has great potential for improving the interdisciplinary GP-physiotherapist communication through knowing each other, and to improve the quality and philosophy of joint care. The process of consultation is there and sets out to improve patient care and patient outcome.

Last but not least consultation will stimulate physiotherapists to work more systematically, in accordance with the current state-of-the-art and body of knowledge of the profession, or in other words, they will become a reflective practitioner (reflection-on-reflection-inaction) as a result of peer review and communication with the referrer.

\section{Implications for further research}

There is some evidence to suggest that the implementation of a well-constructed process of consultation will improve the outcome and efficiency of care and is consistent with the concept of patient-focussed care. Accountability and quality assurance are essential aspects of the consultation process and ought to be subjected to peer review and system analysis 
by all participants on both the local and national level. Identified problems or further development may be influenced by local factors and could be addressed by local evaluation and will initiate the quality circle of continuous quality improvement at the local level.

The most important challenge in understanding the referral for a (one-time) physiotherapist's consultation is trying to see it as a longitudinal process, or case-study approach, which can be viewed from multiple perspectives: the decision to refer and understand the referral, the choice of the consultant, the course and process of the consultation and finally the outcome of the consultation.

However, further research is needed to determine the efficacy of a (one-time) physiotherapist's consultation in a primary care setting on the level of both the patients and the professionals that will convince our harder-nosed colleaques, policy makers and financers of care, of its value.

\section{Recommendations and Guiding Principles}

\section{How to make consultations work?}

Based on the above-mentioned findings, it seems to make sense to formulate the referral to and consultation with the physiotherapists as formally as possible. This formalization must be set down in the legislation as well as in the agreements between parties. For the introduction of a one-time physiotherapist's consultation a number of prerequisite conditions can be listed.

From the literature ${ }^{10,21,79-88}$ as well as from this research, it is known that a weli-defined procedure is conditional to the consultation's success. The consultee must formulate the request clearly, and provide written information to the consultant about the patient's problems, Kersten ${ }^{82}$ and some others ${ }^{79-8 !}$ have proven the importance of a well-defined proposition of procedure to the success of a (one-time) consultation. Unless GPs/ physicians expressly underline consultation in their request, medical specialists wili rarely treat the referral as such. However, if the GP has emphasized the consultation request, it will rarely lead to the specialist taken over the treatment (continuity of care).

Hence, the procedures and forms developed for the purpose of the one-time consultation are important conditions for smooth consultation procedures. Other conditions comprise clarity of arrangements and clear demarcations of responsibilities between GPs and physiotherapists, a positive attitude, a well-organized system of information and reporting, mutual trust, openness and involvement. An harmonious relationship between GPs and physiotherapists is essential for high quality health care. Patients are cruciual partners in the relationship and important ethical principles have to be considered. Efforts to improve the relationship must have as a primary goal the welbeing of the patient. The consultation process consists of a series of steps that emphasize improved communication between the referring GP and the physiotherapist-consultant. Poor communication may complicate the 
process, may harm and/or dissatisfy the patient, the GP, the physiotherapist-consultant and thus may result in dimished quality of patient care, frustrations, confusions and strained relationships between GPs and physiotherapists. To these ends we propose a number of guiding principles for both the professionals to ensure the consultation process. These guidelines are the result of our literature reviews on this topic with medical consultants $^{10.25,85,87.88}$ and our own experiences with a one time physiotherapist's consultation in general practice.

The primary purpose of consultation is to improve the quality of health care by making available to patients and referring GPs the knowledge and skills of physiotherapist consultants at appropriate times. However, the actual decision to refer a patient for a onetime physiotherapist's consultation depends on factors such as expertise, the medical environment, and the patients wishes and needs.

To achieve optimal benefit from consultation referring GPs, patients (and their families) and physiotherapist-consultants the following guiding principles are proposed including a few recommendations for both the professions involved.

Guiding principles for the referring GP are:

1. To ensure that patients understand the need and reason for a one time physiotherapist's consultation. The urgency of the consultation also needs to be established and communicated to both the patient as the consultant as well;

2. To communicate clearly to the physiotherapist consultant the purpose (and reason for the consultation request) and problems for which help is needed, including their findings, investigations and management policy.

Guiding principles for the physiotherapist-consultant are:

1. To provide easy access to their consultation services;

2. To provide consultation at appropriate times or assist referring GPs to find other consultants;

3. To demonstrate courtesy and respect for patient and referring GPs. It is also important for the consultant to clarify his or her role in the process of consultation to the patient. The consultant needs to be diplomatic when discussing the results or issues with the patient and should avoid criticism of the GP's management;

4. To communicate clearly and promptly the findings, advice and recommendations to the referring GP. The advice or recommendations are more likely to be followed if they are concise, based on a sound (evidence-based) rationale and easy to read;

5. To return the patients to referring GPs for continuing care at the appropriate time.

Recommendations for both professional bodies:

1. To make clear arrangements (and responsibilities) between the professional bodies of GPs and physiotherapists about the (structured) procedure and organization (request, communications, reporting and time limits) of the consultation; 
2. To train consultative skills and to formulate criteria for quality by the professional bodies;

3. To define criteria with respect to the minimal requirements and levels of expertise which the physiotherapist must satisfy (for instance, years of general experience, or specific expertise with certain patient populations, knowledge of new insights, and of the research literature etc.);

4. To make appointments about a reasonable remuneration for a one-time physiotherapist's consultation with financers of health care;

5. Objective evaluation of their use and impact on patient care has to be established from both the perspective of the patient as well as the professionals when it will be implemented.

\section{References}

1. Geijer RMM, Burgers JS, Laan van der JR, Wiersma TJ, Rosmalen CFH. Thomas S [Eds]. NHGStandaarden voor de huisarts, deel 1. Maarssen: Elsevier/Bunge, 1999.

2. Raad voor Maatschappelijke Ontwikkelingen (RMO) / Raad voor de Volksgezondheid en Zorg (RVZ). Achtergrondstudies bij het advies zorgarbeid in de toekomst, Den Haag/Zoetermeer: RMO/RVZ, 1999

3. Stichting Toekomstscenario's Gezondheidszorg (STG). Managed care and disease management. Zoetermeer: STG, 1997

4. Kwaliteit in beeld. Special Kwaliteitsconferentie en Leidschendamafspraken. 1995-2000. Zoetermeer: Gezamenlijke uitgave van de NRV en de Geneeskundige Hoofdinspectic, 5e jaargang, nr. 3, blz. 3-6, 1995.

5. Ministerie van Welzijn. Volksgezondheid en Cultuur (WVC). Over de ontwikkelingen van gezondheidsbeleid: feiten, beschouwingen en beleidsvoornemens (Nota-2000). Rijswijk, 1986.

6. Raad voor de Volksgezondheid en Zorg (RVZ). Naar een meer vraaggerichte zorg. Zoetermeer: RVZ, 1998.

7. Hendriks HJM, Bekkering GE, Brand'sma JW, et al. Development and implementation of national practice guidelines: a prospect for continuous quality improvement in physiotherapy. An introduction to the method of guideline development. Physiotherapy 2000 (in press).

8. Borst-Eijlers E. Voortgangsrapportage MTA en doelmatigheid van zorg (Progress report on MTA and efficiency on care). April 2, 1997.

9. Raad voor Gezondheidsonderzoek (RGO). Advies Medical Technology Assessment (Deel 1), Inventarisatie van MTA-onderzoek en aanzet tot coordinatic. Rijswijk: RGO. 1998.

10. Hendriks HJM, Wagner C. Brandsma JW, Dekker J. Wams HWA, Oostendorp RAB. Consultatief Fysiotherapeutisch Onderzoek (CFO) in de eerste lijn. Introduktie van het CFO-project en informatie uit de literatuur. Ned Tijdschr Fysiother 1992;6:176-183.

11. Raad voor de Volksgezondheid en Zorg (RVZ). Professionals in de gezondheidszorg. Zoetermeer: RVZ, 1998.

12. Lamberts H. In het huis van de huisarts. Verslag van het Transitieproject. Lelystad: Meditekst, 1991

13. Rijken PM, van Heugten CM, Dekker J. Brancherapport paramedische zorg. Utrecht: Nederlands instituut voor onderzoek van de gezondheidszorg (Nivel), 1996.

14. Kerssens JJ, Curfs Echr. Extramurale fysiotherapie. Utrecht, PhD dissertation. Netherlands Institute for primary health care (Nivel), 1993

15. Centraal Bureau voor de Statistiek (CBS). Statistisch Jaarboek 1999. Voorburg: CBS, 2000.

16. Uunk W. Dekker J, Groenewegen P. Verwijzingen vani huisartsen naar fysiotherapeuten: morbiditeitsspecifieke verwijspercentages. Deelproject Huisarts en fysiotherapeutische zorg: Basisgegevens uit de Nationale Studie van Ziekten en Verrichtingen in de Huisartsenpraktijk. Utrecht: Nivel, 1991

17. Hulme JB, Wackernagel B, Lewis JW. Communication between physicians and physical therapists. Physical Therapy 1988:68:26-31. 
18. Stanton PE, Fox FK, Francois KM, Hoover DH, Spilecki GM. Assessment of resident physicians' knowledge of physical therapy. Physical Therapy 1985;65:27-30.

19. Uili RM, Shepard K, Savinar E. Physician knowledge and utilization of physical therapy procedures. Physical Therapy 1984;64:1623-1530.

20. Rijdt van der T, Lubbers M, Kolker L. Het verbeteren van samenwerking. Eindverslag van het project Samenwerking huisarts en fysiotherapeut. Utrecht: Stichting O\&O, 1990.

21. Hendriks HJM, Wagner C, Dekker J, Brandsma JW. Evaluatie van het consultatief fysiotherapeutisch onderzoek in de eerste lijn. Resultaten van een veldexperiment. Utrecht: Nivel, 1994.

22. Ritchey FJ, Pinkston D, Goldbaum JE, Heerten ME. Perceptual correlates of physician referral to physical therapisst: Implications for role expansion. Soc Sci \& Med 1989;28:69-80.

23. Anderson J. Campbell SK. Correlates of physician utilization of physical therapy. International Journal of Technology Assessment in Health Care 1992;8(1):10-19.

24. Oostendorp RAB, van Ravensberg CD, Wams HWA, Heerkens YF, Hendriks HJM. Fysiotherapie, wat omvat het? Bijblijven 1996:12:5-17.

25. Higgs J, Titchen A. Research and knowledge. Physiotherapy 1998;84:72-80.

26. Hendriks HJM, Oostendorp RAB, Bernards ATM, Van Ravensberg CD, Heerkens YF, Nelson RM. The diagnostic process and indication for physiotherapy: a prerequisite for treatment and outcome evaluation. Physical Therapy Reviews 2000:5:29-47.

27. Beckerman H, Bouter LM, Heijden GJMG van der, Bie RA de, Koes BW. Efficacy of physiotherapy for musculoskeletal disorders: what can we learn from research? Brit J Gen. Pract 1993;43:73-7.hulme

28. Gezondheidsraad. De effectiviteit van fysische therapie; electrotherapie, lasertherapie, ultrageluidbehandeling. Den Haag: Gezondheidsraad, 1999.

29. Hendriks HJM, Wagner C, Brandsma JW, Oostendorp RAB, Dekker J. Experiences with physiotherapsist consultation. Results of a feasibility study. Physiother Theory Prac 1996;12(4):211-20.

30. Mischner-van Ravensberg CD, Paauw HJM, Gestel JLM. De fysiotherapeutische werkdiagnose in relatie tot de medische diagnose. Ned Tijdschr Fysiotherapie. 1988;98:104-107.

31. KNGF (Koninklijk Nederlands Genootschap voor Fysiotherapie). Richtlijnen voor de fysiotherapeutische verslaglegging, KNGF: Amersfoort, 1993.

32. Klaveren AA van, Ravensberg CD van, Oostendorp RAB, Hendriks HJM, Elvers JWH. Basisregistratie Fysiotherapie. Een inventarisatie van het fysiotherapeutisch handelen in de eerste lijn. Amersfoort: Nederlands Paramedisch Instituut. (NPi), 1995.

33. Valk R van der, Dekker J، Boschman M. Basisgegevens extramurale fysiotherapie 1989-1992. Gegevens uit het project "Beleidsgericht Evaluatie- en Effectonderzoek Fysiotherapie (BEEF)". Utrecht: Nivel, 1995.

34 Dekker J, van Baar ME (eds). Beleidsgericht Evaluatie- en Effectonderzoek Extramurale Fysiotherapie 1989. 1992. Utrecht: Nederlands instituut voor onderzoek van de gezondheidszorg (Nivel), 1995.

35. Rose S. Physical therapy diagnosis: role and function. Phys Ther. 1989;69:535-537.

36. Sahrmann SA. Diagnosis and classification by physical therapist: a special communication. Physical Therapy 1988;11:1703-06.

37. Dekker J. Application of the ICIDH in survey research on rehabilitation: the emergence of the functional diagnosis. Disabil Rehabil. 1995;17:195-201.

38. Uunk WJG, Groenewegen PP, Dekker J. Verwijzingen van huisartsen naar fysiotherapeuten: een verklaring en analyse van verschillen tussen huisartsen. Mens en Maatschappij 1992;67:389-411.

39. Hendriks HJM, Kerssens JJ, Dekker J, Oostendorp RAB, Van der Zee J, Nelson RM. Physical therapist consultation in general practice: its use and impact on the process of care. Physicall Therapy' (accepted).

40. Stokx LJ, Gloerich ABM, Kersten TJJMT, Kostenbesparing door kwaliteitsbevordering. Utrecht: Nivel, 1992.

41. Stokx LJ, Bakker DH de, Delnoy DMJ, Gloerich ABM, Groenewegen PP. Verwijscijfers belicht. Utrecht: Nivel, 1992.

42. Ravensberg $C D$ van, Klaveren AAJ van, Wams HWA, Oostendorp RAB, Elvers JWH, Hendriks HJM. Variabelen in samenhang met aantal behandelingen fysiotherapie: analyse FON-PPP-gegevens. Nederlands Paramedisch Instituut (NPi): Amersfoort, 1995.

43. Roebroeck ME, Hutten JBF, Kerssens JJ, Dekker J. De omvang van de fysiotherapeutische behandeling naar verschillende patiēntencategoriečn. Nederlands instituut voor onderzock van de gezondheidszorg (Nivel): Utrecht, 1995. 
44. Zuijderduin W, Dekker J, Abrahamse H. Determinanten van de omvang van de behandeling in de extramurale fysiotherapie. Tijdschrift voor Sociale Gezondheidszorg 1995;73:274-281.

45. Hendriks HJM, Kerssens JJ, Bekkering GE, Dekker J, Zee van der J, Oostendorp RAB. Determinants of the number of sessions per physiotherapy treatment episode (submitted).

46. Akpala CO, Curran AP, Simpson J. Physiotherapy in general practice: patterns of utilization. Public Health 1988; 102:263-68.

47. Yoshida KK, Allison KR. Sociodemographic and health-related characteristics of Ontarians making contact with physical therapists: analysis of the 1990 Ontario health survey. Physiotherapy Canada 1997:49:214-221.

48. Gloerich ABM, van der Zee J. Determinanten vasn verwijzen door de huisarts naar de tweedelijn. Deelproject van de Nationale Studie van Ziekten en Verrichtingen in de Huisartsenpraktijk. Utrecht: Nivel, 1992.

49. Velden J van der, Bakker DH de, Claessens AAMC, Schellevis FG. Nationale studie naar ziekten en verrichtingen in de huisartsenpraktijk. Basisrapport: Morbiditeit in de huisartsenpraktijk. Utrecht: Netherlands institute of primary health care (Nivel), 1991.

50. Prescot-Clarke P. Brooks T, Machray C. Focus on health care: surveying the public in four health care districts. London: Royal institute of Public administration and Social and Community Planning Research, 1988.

51. Hays RD, Ware JE. My medical care is better than yours: social' desirability and patient satisfaction ratings. Med Care 1986; 24(6): 519-524.

52. Visser AP. Education in the hospital: differences in satisfaction, cognition, and emotional status between younger and older patients. Tijdschr Gerontol Geriatr 1988;19(3):113-119.

53. Mielenz TJ, Carcy TS, Dyrek DA, et al. Physical therapy utilization by patients with acute low back pain. Phys Ther. 1997;77:1040-1051.

54. Grundmeijer HGLM, Weert van HCPM, Brouwer HJ. Wat is goed verwijzen en kan het beter? Een literatuuronderzoek. Huisarts Wet 1996;39:113-119.

55. Lisdonk van de FH, Schellevis FG. Interdoktervariatic en de kwaliteit van verwijzen. Een literatuuronderzoek. Huisarts wet 1994:37:573-578.

56. Fertig A, Roland M, King H, Moore T. Understanding variation in rates of referral among general practitioners: are inappropriate referrals important and would guidelines help reduce to reduce rates? BMJ $1993 ; 307: 1467-1470$ :

57. Reynolds D, Chitnis JE, Roland MO. General practitioners referrals: do good doctors refer more patients to the hospital? BMJ $1991 ; 302: 1250-1252$.

58. Knotnerus JA, Joosten J. Daams J. Comparing the quality of referrals of general practitioners with high and average referral rates: an independent pane! review, Br J Gen Pract 1990;40:178-181.

59. Knottnerus JA, Metsemakers JFM. Chronische ziekte in de huisartspraktijk: prevalentic, multimorbiditeit, sociale prevalentie. Huisarts Wet 1996:39:494-497.

60. Rijkșinstituut voor de Volksgezondheid en Milieu (RIVM). Volksgezondheid Toekomstverkenningen 1997. Effecten van zorg. Bilthoven: Elsevier / de Tijdstroom, 1997.

61. Bakker de DH. Substitutie van tweedelijnszorg door fysiotherapeuten en eerstelijnssamenwerking. Utrecht: Nivel (intern rapport), 1993.

62. Heerkens YF. Vogels EMHM, Wiarda VL, va Ravensberg CD. Verslag van het onderzoek: fysiotherapeutische diagnose. Amersfoort: KNGF/NPi, 1997.

63. World Health Organization (WHO). ICIDH, International Classification of Impairments, Disabilities, and Handicaps: a manual' of classification relating to the consequences of discase. Geneva: WHO, 1980.

64. World Health Organization (WHO). International Classification of Impairments, Activities and Participation: a manual of dimensions of disablement and functioning (ICIDH-2). Geneva: WHO, 1997.

65. Hendriks HJM, Reitsma E, Ettekoven $\mathrm{H}$ van. Centrale Richtlijnen in de Fysiotherapie. Introductie van het CR-project. Nederlands Tijdschr Fysiotherapie 1996; 106(1):2-1 I,

66. Raad voor de Volksgezondheid en Zorg (RVZ). Prikkels tot doelmatigheid. Zoetermeer: RVZ, 1998.

67. Velden van der LFJ. Hingstman L, Groenewegen PP. Verkenning van vraag-en aanbodontwikkelingen binnen de medische en paramedische zorg: knelpunten en oplossingen. In: Raad voor Maatschappelijke Ontwikkelingen (RMO) / Raad voor de Volksgezondheid en Zorg (RVZ). Achtergrondstudies bij het advies zorgarbeid in de toekomst,Den Haag/Zoetermeer: RMO/RVZ, 1999. 
68. Raad voor de Volksgezondheid en Zorg (RVZ). Redesign van de eerste lijn in transmuraal perspectief. Zoetermeer: RVZ, 1998.

69. Raad voor de Volksgezondheid en Zorg (RVZ). Transmurale zorg: redesign van het zorgproces. Zoetermeer: RVZ, 1998.

70. de Bie RA, Hendriks HJM, Lenssen AF, van Moorsel SR, Opraus KWF, Remkes WFA, Swinkels WFA. KNGF-richtlijn Acuut Enkelletsel. Ned Tijdschr Fysiother 1998;108: supplement no, 1.

71. Berghmans LCM, Bernards ATM, Bluyssen AMWL, Grupping-Morel MHM, Hendriks HJM, de Jong-van lersel MJEA, Raadgers MC. KNGF-richtlijn Stress-incontinentie. Ned Tijdschr Fysiother 1998;108: supplement no. 2 .

72. Bekkering GE, Hendriks HJM, Chadwick-Straver RVM, et al. KNGF-richtlijn COPD. Ned Tijdschr Fysiother 1998;108: supplement no. 3.

73. Vogels EMHM, Hendriks HJM, van Baar ME, Dekker J, Hopman-Rock M, Oostendorp RAB, Hullegie WAMM, Bloo H, Hilberdink WKHA, Munneke M, Verhoef J. KNGF-richtlijn "Artrose heup - knie". Amersfoort: KNGF/NPi, 2000.

74. Smits-Engelsman BCM, Bekkering GE, Hendriks HJM. KNGF-richtlijn Osteoporose. Amersfoort: $\mathrm{KNGF} / \mathrm{NPi}, 2000$,

75. Bekkering GE, Hendriks HJM, Lanser K, Oostendorp RAB, Peeters GGM, Verhagen AP, van der Windt DAWM. KNGF-richtlijn Whiplash. Amersfoort: KNGF/NPi, 2000.

76. Bekkering GE, Hendriks HJM, Koes B, Oostendorp RAB, Ostelo RWJG, Thomassen J, van Tulder MW, KNGF-richtlijn Lage Rugklachten. Amersfoort: KNGF/Npi, 2000.

77. Hendriks HJM, van Ettekoven H, Reitsma E, van der Wees Ph. Eindverslag van het project Centrale Richtijnen (CR) in de Fysiotherapic. Deel I: achtergronden en evaluatie van het project. Amersfoort/Utrecht: $\mathrm{KNGF} / \mathrm{CBO} / \mathrm{NPi}, 1998$.

78. Hendriks HJM, van Ettekoven H, Reitsma E, Verhoeven A, van der Wees Ph. Methode voor centrale richtlijnontwikkeling en. implementatie in de fysiotherapie. Amersfoort/Utrecht: KNGF/CBO/NPi, 1998.

79. McPhee SJ, Lo B, Saika Y, Meltzer R. How good is communication between primary care physicians and subspecialty consultants? Archives of Internal Medicine 1984;144:1265-1268.

80. Pop P. Kerkhof PD. Diagnostisch Centrum Maastricht, Eindevaluatie van een experiment. Medisch Contact. 1984;39:749-752.

81. Beek. M, Eijk J van, Rutten G. Verschuivingen van eerste naar tweede lijn? Opvattingen van huisartsen en specialisten. Medisch Contact 1985:40:299-302.

82. Kersten TJJMT. De invloed van de huisarts op de specialist. Een theoretische analyse getoetst aan de opvattingen van huisartsen. T Soc Gezondheidszorg 1992;70:171-179.

83. Katon W, Gonzales J. A review of randomized trials of psychiatric consultation-liaison studies in primary care. Psychosomatics 1994;35:268-278.

84. Katon W, Von Korff M, Lin E. Simon G, Walker E, Unutzer J, Bush T, Russo J, Ludmann E. Stepped collaborative care for primary care patients with persistent symptoms of depression: a randomized trial. Arch Gen Psychiatry 1999:56:1109-1115.

85. Vierhout WPM. Het gezamenlijk consult van huisarts en specialist in de eerste lijn. Een nieuwe werkwijze bij klachten van het bewegingsapparaat [Dissertatie]. Maastricht: Rijksuniversiteit Limburg, 1994.

86. Hendriks HJM, De Bie RA, Van der Zee J. Consultation between General. Practitioners and medical. consultants in the Dutch health care system. What can we learn from the literature? (submitted),

87. College of Family Physicians of Cananda / Royal College of Physicians and Surgeons of Cananda. Relationship between Family physicians and specialist/consultants in the provision of patient care. canadian Family Physician 1993:39:1309-1312.

88. Marshall JB. How to make consultations work? Postgraduate Medicine 1988;84:253-257. 


\section{Summary}

The current policy of Dutch primary health care is to provide accessible and high-quality care. Cost containment, however, is a central issue in health care policies all over the world, and is also the aim of Dutch policy initiatives and directives. This emphasis on cost containment directly affects physiotherapeutic care and requires that physiotherapists make choices in the provision of care, and help develop strategies that will improve the quality, outcome and efficiency of that care.

Within primary care, treatment referrals are most often made to physiotherapy. Thus, physiotherapy plays an important role in the therapeutic options available to GPs. This high rate of referral for patient treatment demands a good working relationship between GPs and physiotherapists. However, several problems have been identified concerning GPs' working relationship with physiotherapists. These problems include: poor communication, lack of knowledge about physiotherapy, uncertainty about indications for referral, and doubt about the efficacy of physiotherapy treatment.

It is proposed that the communication between GPs and physiotherapists, and ultimately patient care, could be improved through the provision of a one-time patient consultation by physiotherapists. Chapter one presents the background, objectives and scope of the thesis "Physiotherapist's Consultation in General Practice" and is divided into four sections,

\section{Part I: Introduction}

After an introduction to the study chapter 2 presents both the differences between medical and physiotherapist's diagnoses and the complementary nature between these disciplines, and establishes a systematic approach to identify relevant information for determining the appropriate indications for physiotherapy, for quality improvement in patient care activities and for the development of meaningful outcome research. The need for the profession of physiotherapy to illustrate its value to the external world is becoming more important each year. It is incumbent on the profession to design a conceptual framework for the physiotherapy process which can be used to study the effectiveness of physiotherapy using appropriate clinical research techniques.

The purpose of chapter 2 is to present a systematic approach to the delivery of physiotherapy interventions. The stages within this conceptual framework are described in detail. In the first step the referring physician determines the medical diagnosis and the indication for physiotherapy, followed by the referral data. Based on the referral data the physiotherapist must formulate a physiotherapist's diagnosis that is based on the patient's clinical symptoms 
and signs, the functional health status and relevant prognostic (e.g. psychosocial) factors. The treatment plan that is subsequently developed and implemented is described in similar detail. Finally the patient outcomes that result from the intervention are addressed and subsequently used in evaluation of the treatment. A systematic approach of the process of physiotherapy practice is a prerequisite to improve the quality of patient care activities and to design meaningful RCTs.

Chapter 3 reviews the research literature documenting the different types of consultation models and the effects on the process and outcome of care between GPs and medical consultants utilized in the Dutch health care system. Medical care becomes more specialised and complex and as a consequence the general practitioner's role in the provision of optimal continuing care becomes both more important and more challenged by the full set of encountered biomedical, psychosocial, and behavioral health problems. The implementation of consultation models is hypothesized as an interesting strategy to support the GP in clinical practice and to improve their relationship with other health care providers.

A literature search have identified 27 articles that studied the effects of five different types of consultation models on the process of care and patient outcome. Although the results of the review suggest beneficial effects on both the process of care and clinical outcome. there is no convincing evidence that any type of consultation leads to clinical benefits and changes of GPs' process of care (behaviour). More rigorous studies are needed to evaluate the effectiveness of consultation in a variety of settings, providers, patients, and health problems.

\section{Part II: Preliminary studies, research questions, and study design}

Chapter 4 presents the results of a feasibility study of a one-time physiotherapist's consultation in general practice as part of the main study on the effects and feasibility of a one-time physiotherapist's consultation in general practice. The overall objective of the study was to establish whether consultations by physiotherapists would influence the number of referrals made by GPs to medical specialists and physiotherapists in either a. qualitative or quantitative way. The aim of the smaller feasibility study was to assess the consultation procedure and the standard forms between $14 \mathrm{GPs}$ and 8 physiotherapists. The data were collected using questionnaires and registration forms. The GPs found both the consultation procedure and the standard consultation forms to be suitable for the purpose of consulting a physiotherapist. In $93 \%$ of cases, GPs felt the outcome of the consultation to be satisfactory. The present results suggest that the appropriateness of referral can be improved by written communication between a GP and physiotherapist. The nature of this feasibility study does not allow generalization of the results, due to the optimal conditions in which it was performed and the small numbers of GPs and physiotherapists studied, between whom there was already good. communication and cooperation. However, the aim of the feasibility study was simply to test the consultative process, the questionnaires employed, and the standard consultation forms developed. The process of written consultation was apparently justified by this study. 
Chapter 5 presents the results of the study on the intraobserver and interobserver reliability of assessments of impairments and disabilities using standard forms. The concepts of the International Classification of Impairments, Disabilities, and Handicaps provide a framework for the assessment of functional status. With the ICIDH, it is possible to describe and evaluate the functional status of a patient at different levels: the tissue-organ-organ system level (impairments), the personal level (disabilities), and the social level (participation problems [handicaps]). The purpose of this study was to evaluate the intraobserver and interobserver reliability of assessments of impairments and disabilities.

One physiotherapist's assessments were examined for intraobserver reliability and judgments of two pairs of physiotherapists were used to examine interobserver reliability. Reliability was assessed by percentage of agreement and Cohen's kappa.

The assessment of impairments and disabilities is potentially reliable. The differences between practices of the interobserver reliability segment of the study can be explained by the fact that one of the physiotherapists did not receive training in the use of the assessment form. More general conclusions will require further study with more subjects and therapists.

Chapter 6 presents the objectives, research questions and design of the field study in detail. To evaluate the effect of a one-time physiotherapist's consultation, an observational study was conducted. Of great importance in the study's design was the testing of the process and outcome of physiotherapist's consultations in a representative group of GPs and physiotherapists rather than a highly motivated select group. Hence, it was critical that the process of physiotherapist's consultation be easily incorporated into the daily practice of both GPs and physiotherapists, so as not to disturb the day-to-day work situation. Further, the (experimental) possibility of physiotherapist's consultation needed to fit into existing, regular modes of cooperation between GPs and physiotherapists.

The physiotherapist's consultation was defined as: "a written request from a GP to a physiotherapist to make an assessment of a particular patient in order to generate information concerning diagnosis and prognosis, with a view to treatment policy to be prescribed by the physician, especially where physiotherapeutic interventions are concerned." From this definition it should be clear that the intention of the physiotherapist's consultation is not to create a freely accessible consultation hour. The consultation only takes place at the express request of the GP. This confers sole responsibility for the chosen management policy on the GP.

A 7-month observation study was conducted with 59 pairs of randomly selected GPs and physiotherapists. Data were collected at the level of the GP, the physiotherapist, and the patient referred for a one-time physiotherapist's consultation. Self-administered questionnaires, consultation requests, standardized forms and treatment referral data from health insurance agencies were used to obtain data. The outcomes were the number and nature of consultation requests; patient characteristics, the GP's opinion on the outcome of consultation, and referral patterns. Each GP had the opportunity to consult the. physiotherapist (with whom he or she was paired) by referring patients through the use 
of consultation request and report forms. The objectives of this research were to determine the effects of physiotherapist's consultations in terms of: (1) the quality and efficiency of care provision based on the opinion of consultation outcome; (2) the number of referrals by GPs to physiotherapists and medical specialists when the locomotor system was involved; and (3) the extent to which physiotherapists were able to predict the outcome of physiotherapeutic intervention, based on a one-time consultation.

\section{Part III. Resuits}

Chapter 7 focuses on the results of a one-time physiotherapist's consultation from the perspective of the GPs, such as their frequency of use, opinion of the outcome and its impact on their management decisions after the consultation by a group of GPs.

The main reasons cited for consultation were the need for diagnostic information (26\%) and the need to determine an indication for physiotherapy (29\%). In $94 \%$ of the cases, GPs evaluated the outcome of consultation requests to be satisfactory. Most GPs (93\%) agreed with the physiotherapist's recommendation, which resulted in $50 \%$ of cases being managed in a different manner than was intended before consultation.

The results show that GPs used the opportunity for a one-time physiotherapist's consultation and they were satisfied with the outcome and process of consultation. The findings suggest that a one-time physiotherapist's consultation is an appropriate and beneficial component of a GP's patient management process.

Chapter 8 describes the effects of a one-time physiotherapist's consultation on the utilization of physiotherapy services, functional outcome and number of treatment sessions per treatment episode. Patterns of referral for physiotherapy treatment after consultation was positively related with increased age of the patients, lower levels of education, longer duration of the complaints and a decrease in physical functioning measured in terms and number of impairments and disabilities. Functional outcomes were comparable with national reference data of patients referred by GPs for physiotherapy treatment. The mean number of sessions per treatment episode, including a one-time consultation, was significant lower when compared with the national reference data.

The findings indicate that a one-time physiotherapist's consultation improve appropriate referral, utilization and transparency of physiotherapy services.

Furthermore, in Chapter 9 we explored the determinants of the total number of sessions per treatment episode related with the recently changed remuneration system. The objective of this study was to determine patient, physiotherapist and practice setting characteristics associated with the number of sessions per physiotherapy treatment episode of patients referred by a primary care physician / general practitioner (GP).

Data of complete treatment episodes were collected during an observational study with complete follow up of patients being treated by a therapist following the consultation. Hierarchical logistic regression modelling was used to estimate the probability of being treated within 9 versus ten or more sessions (9-sessions model) or within 18 versus 19 or more sessions per treatment episode (18-sessions model).

The database contains information on 2,574 therapy sessions for 224 patients with a broad 
range of musculoskeletal disorders, who were treated by 53 physiotherapists working in different private practices in primary care.

The mean number of sessions per treatment episode was $11.5(\mathrm{sd}=7.8)$, ranging from 3 to 34 . Fifty-three percent of the patients were treated in nine or less treatment sessions. Among the included patient characteristics only the patient's age was found to be related with the probability of being treated within nine versus ten or more sessions per treatment episode (the older the patient the more likely to be treated in ten or more sessions). Among the included physiotherapist and practice setting characteristics, the age of the physiotherapist, the specialties manual therapy and pediatric physiotherapy and the number of professional partners were found to be important determinants of the volume of physiotherapy care. The variation in the number of sessions per treatment episode may be influenced by physiotherapist and practice setting characteristics and not only by the patient or clinical status characteristics. This finding needs to be studied in further research, to include other factors such as the physiotherapist's behaviour, attitude and level of education because it might explain the sources of (clinical) variation in number of sessions per physiotherapy treatment episode.

\section{Part IV. General Discussion}

In the concluding section of the thesis (Chapter 10), the main findings of the study are summarized and briefly discussed with respect to future directions. Several methođological limitations and ethical topics are also discussed, and the implications of the study with respect to general practice, current health care reform and future research are considered. Finally, guiding principles and recommendations for implementing a one-time physiotherapist's consultation in general practice are proposed. 
212 


\section{Samenvatting}

Het huidige beleid in de Nederlandse gezondheidszorg is gericht op het realiseren van een toegankelijke en kwalitatief goede zorg. Huidige beleidsinitiatieven zijn vooral gericht op de beheersbaarheid van de kosten van de gezondheidszorg. Deze beleidsmaatregelen hebben ook consequenties voor de fysiotherapeutische zorg in de eerste lijn. Enerzijds wordt er een trendmatige toename van het gebruik van fysiotherapeutische zorg verwacht, anderzijds wordt door het huidige volumebeleid de fysiotherapeutische zorgverlening beperkt. Deze situatie leidt tot de noodzaak om keuzes te maken in het verlenen van zorg en om maatregelen te nemen ter bevordering van de doeltreffendheid en doelmatigheid van de fysiotherapeutische zorg.

Binnen de eerstelijnsgezondheidszorg neemt de huisarts als poortwachter tot de gezondheidszorg een sleutelpositie in. Huisartsen hebben via hun verwijsbeleid een grote invloed op het aantal patiènten dat onder fysiotherapeutische behandeling is, maar ook op de aard van de problematiek waarmee de fysiotherapeut wordt geconfronteerd. Fysiotherapie is binnen de eerste lijn de discipline waarnaar het meest wordt verwezen. Geconcludeerd kan worden dat fysiotherapie een belangrijke rol speelt in het therapeutische arsenaal die de huisarts tot zijn beschikking heeft. Hoewel dit hoge verwijscijfer een goede samenwerking tussen huisartsen en fysiotherapeuten veronderstelt, wordt er echter een aantal problemen gesignaleerd zoals slechte communicatie, onvoldoende kennis van de mogelijkheden van fysiotherapie, onduidelijkheid over de indicatiestelling voor fysiotherapie en twijfel over de doeltreffendheid en doelmatigheid daarvan. Verondersteld werd dat de communicatie tussen huisartsen en fysiotherapeuten, en uiteindelijk de patiëntenzorg, verbeterd zou kunnen worden door het invoeren van de mogelijkheid om een fysiotherapeut eenmalig te consulteren (het Consultatief Fysiotherapeutisch Onderzoek [CFO]) voorafgaande aan een (eventuele) verwijzing voor behandeling.

\section{Deel 1: Introductie}

$\mathrm{Na}$ een algemene inleiding van het onderzoek wordt in het tweede hoofdstuk ingegaan op de verschillen en overeenkomsten tussen de medische en fysiotherapeutische diagnose. In dit hoofdstuk wordt op basis van de beschikbare literatuur het methodisch fysiotherapeutisch handelen systematisch beschreven. Inzicht in de werkwijze en doelstellingen van fysiotherapeuten is een voorwaarde om het noodzakelijke onderzoek naar de effectiviteit van fysiotherapie te verbeteren. 
Fysiotherapeuten beschikken over een beroepseigen deskundigheid waarmee zij, in relatie tot de de medische (verwijs-)diagnose, de fysiotherapeutische diagnose kunnen stellen. Een fysiotherapeutisch onderzoek is nodig omdat in de praktijk blijkt dat de medische verwijsgegevens niet specifiek genoeg zijn om het fysiotherapeutisch handelen te sturen.

De fysiotherapeutische diagnose is naast de hulpvraag van de patiënt en de medische (verwijs-)diagnose, gebaseerd op de gezondheidstoestand (in termen van stoornissen in functies en structuren, beperkingen in activiteiten en participatieproblemen) en relevante psychosociale factoren van de patiënt. Het behandelplan en de daaruit afgeleide doelstellingen (en relevante uitkomstmaten) van de fysiotherapeutisch zorg, worden vervolgens beschreven. Kennis van diagnostische en therapeutische processen zijn van belang voor een doelmatige en doeltreffende zorg en dienen als basis voor het ontwerpen van gecontroleerde klinische onderzoeken die recht doen aan het fysiotherapeutisch handelen.

Hoofdstuk 3 geeft een overzicht van de verschillende vormen van consultatie en de effecten daarvan op de zorgverlening en de gezondheidstoestand van de patiënt. De medische zorg wordt steeds complexer, door een interactie van biomedische en psychosociale factoren en het gedrag van de patiënt, waardoor de rol van de huisarts om de continuîteit van de zorg te bewaken zowel moeilijker als uitdagender wordt. De veronderstelling is dat de huisarts door gebruik te maken van (verschillende vormen van) consultatie ondersteund wordt in zijn/haar beleid hetgeen kan bijdragen tot een verbetering van de samenwerking met andere zorgverleners. Een literatuurstudie naar de effecten van consultatie in de Nederlandse gezondheidszorg leverde 27 publikaties op. Hoewel de resultaten van de onderzoeken, op zowel het zorgproces als op de klinische uitkomsten, een positief beeld schetsen, is er geen overtuigend bewijs dat consultatie daadwerkelijk leidt tot veranderingen in het beleid van de huisarts en tot een meer doelmatige en doeltreffende patiëntenzorg. Meer gecontroleerde onderzoeken zijn nodig om de effectiviteit van (verschillende vormen van) consultatie te evalueren bij verschillende zorgverleners, patiënten en hun gezondheidsproblemen.

\section{Deel II: Voorbereidende studies, onderzoeksvragen, en onderzoeksopzet}

De hoofddoelstelling van het onderzoek is het vaststellen van de effecten van een verwijzing voor een CFO op de "kwaliteit" van de zorgverlening en op het aantal verwijzingen van huisartsen naar medisch specialisten en fysiotherapeuten. In hoofdstuk. 4 worden de resultaten van een pilot-studie, met als doel het testen van de consultatieprocedure en de standaard consultatieformulieren, beschreven. De pilot-studie is uitgevoerd bij een geselecteerde groep van 14 huisartsen en 8 fysiotherapeuten. De gegevens werden verzameld met behulp van vragenlijsten en registratieformulieren. De huisartsen vonden zowel de consultatieprocedure als de standaard consultatieformulieren geschikt voor een verwijzing voor een CFO. De resultaten doen tevens vermoeden dat de indicatiestelling kan worden verbeterd door (schriftelijk) overleg tussen huisarts en fysiotherapeut. 
Generalisatie van deze resultaten is niet mogelijk door het kleine aantal huisartsen en fysiotherapeuten en de optimale omstandigheden waarin de pilot-studie is uitgevoerd, zoals het reeds bestaan van een goede samenwerking en overlegstructuur. De pilot-studie was met name nodig voor het testen van de ontwikkelde consultatieformulieren, de consultatieprocedure, de (evaluatieve) vragenlijsten en de haalbaarheid van het CFO in de praktijk.

Het doel van het onderzoek dat wordt beschreven in hoofdstuk 5 is het vaststellen van de intra- en interbeoordelaarsbetrouwbaarheid van de functionele gezondheidstoestand (in termen van stoornissen en beperkingen) bij een patiēnt door gebruik te maken van begrippen van de ICIDH op een standaard registratieformulier. De ICIDH voorziet in een raamwerk om de functionele gezondheidstoestand van een patiēnt op verschillende niveau's te beschrijven en te evalueren (op het weefsel-orgaan-orgaansysteem niveau [stoornissen], op het niveau van activiteiten [beperkingen] en op het niveau van participatie [participatieproblemen]). De resultaten impliceren dat de intra- en interbeoordelaarsbetrouwbaarheid van het registratieformulier voldoende is (met uitzondering van enkele items) voor inventariserend onderzoek en voor het vastleggen van inhoudelijke gegevens in de dagelijkse praktijkvoering van de fysiotherapeut. De verschillen in de inter-beoordelaarsbetrouwbaarheid tussen de twee praktijken kan worden verklaard door het feit dat één van de fysiotherapeuten niet was getraind in het gebruik van het registratieformulier. Vervolgonderzoek met een groter aantal patiënten en therapeuten is nodig om meer algemene conclusies te kunnen trekken.

Hoofdstuk 6 beschrijft de doelstellingen, de onderzoeksvragen en het ontwerp van de observationele studie. Een belangrijk uitgangspunt bij de opzet van de studie was dat het CFO getesi zou worden bij een representatieve groep van huisartsen en fysiotherapeuten. Dit betekende o.a. dat het onderzoek niet uitgevoerd zou worden bij een geselecteerde groep van zeer gemotiveerde huisartsen en fysiotherapeuten. Om deze reden was het van groot belang dat de procedure van het CFO goed inpasbaar zou zijn in de dagelijkse praktijkvoering van huisartsen en fysiotherapeuten en de dagelijkse praktijksituatie niet te zeer zou verstoren (bijvoorbeeld door een tijdrovende registratie van gegevens).

Het CFO is gedefinieerd als "een schriftelijk verzoek van een huisarts aan een fysiotherapeut om bij een bepaalde patiënt een fysiotherapeutisch onderzoek te verrichten met als doel het genereren van informatie ten behoeve van diagnose en prognose met het oog op het door de arts vast te stellen behandelbeleid, in het bijzonder waar het de fysiotherapeutische (on)mogelijkheden betreft". Uit deze definitie blijkt dat het niet de bedoeling is door middel van het CFO een vrij toegankelijk spreekuur van de fysiotherapeut te creëren. De consultatie vindt uitsluitend plaats op uitdrukkelijk verzoek van de huisarts. Dit betekent tevens dat de huisarts de verantwoordelijkheid blijft dragen voor het te voeren beleid.

Voor het onderzoek werd bij een aselecte groep van 59 huisartsen en 59 fysiotherapeuten, verdeeld over vier verschillende regio's, gedurende zeven maanden de mogelijkheid voor een CFO geïntroduceerd. Gegevens werden verzameld op het niveau van de huisarts, de fysiotherapeut en de patiẻnt. Iedere huisarts had de mogelijkheid om patiënten voor 
consultatie naar een (aan hem of haar gekoppelde) fysiotherapeut te verwijzen gebruik makend van de consultaanvraag- en rapportageformulieren. Dit veldexperiment had tot doel de effecten van het CFO te bepalen in termen van: (1) de kwaliteit en doelmatigheid van de zorgverlening en in welke mate het CFO voldoet aan de behoefte en verwachtingen van huisartsen en fysiotherapeuten; (2) het aantal verwijzingen van huisartsen naar fysiotherapeuten en medisch specialisten; en (3) de mate waarin fysiotherapeuten, gebaseerd op een CFO, in staat waren het resultaat van een fysiotherapeutische behandeling te voorspellen.

\section{Deel III: Resultaten}

Hoofdstuk 7 beschrijft de resultaten van het CFO vanuit het perspectief van de huisarts, zoals de mate waarin zij van de mogelijkheid van consultatie gebruik maakten, hun mening over de mate waarin de consultvraag was beantwoord en de invloed van het advies van de fysiotherapeut op hun beleid.

De voornaamste redenen voor een consultatieve verwijzing waren de behoefte aan aanvullende diagnostische informatie (26\%) en het vaststellen of er een indicatie was voor fysiotherapie (29\%). In vrijwel alle gevallen (94\%) was de huisarts tevreden over het CFO. De meeste huisartsen (93\%) waren het eens met de aanbeveling(en) van de fysiotherapeut, hetgeen in $50 \%$ van de gevallen resulteerde in een ander behandelbeleid dan de huisarts zonder consultatie gevoerd zou hebben.

De resultaten tonen aan dat huisartsen gebruik maken van de mogelijkheid voor een CFO en dat zij tevreden waren met het resultaat en de procedure van het CFO. Deze bevindingen duiden erop dat het CFO een bruikbaar en nuttig onderdeel kan zijn in het beleid van de huisarts.

In hoofdstuk 8 wordt nader ingegaan op kenmerken van patiënten die na een CFO worden verwezen naar een fysiotherapeut, medisch specialist of door de huisarts zelf worden behandeld. Vervolgens wordt het resultaat van fysiotherapie en de omvang van de zorg van patienten die na een $\mathrm{CFO}$ werden behandeld nader beschouwd. De kans op een verwijzing voor fysiotherapie na een CFO blijkt gerelateerd aan de (hogere) leefijd van de patiënt, (lagere) opleiding, (langere) duur van de klachten en (een vermindering in) de mate van functioneren gemeten in termen van stoornissen en beperkingen. De functionele uitkomstmaten waren vergelijkbaar met de nationale referentiegegevens van patiënten die door huisartsen voor fysiotherapie werden verwezen. Het gemiddeld aantal zittingen per behandelepisode, de consultatie inbegrepen, was significant lager in vergelijking met de nationale referentiegegevens. Deze bevindingen tonen aan dat het CFO kan bijdragen tot een meer adequate verwijzing en doelmatige zorg.

In hoofdstuk 9 worden de resultaten beschreven van een onderzoek naar de determinanten van de omvang van de zorg (aantal zittingen per behandelepisode). Het doel van dit onderzoek is het bepalen van de invloed van patiënt-, fysiotherapeut- en praktijkkenmerken op het aantal zittingen per fysiotherapeutische behandelepisode.

Gegevens van volledige behandepisodes werden verzameld gedurende een observationele studie met een volledige 'follow up' van patiënten die na een CFO door een fysiotherapeut 
werden behandeld. De data werden geanalyseerd middels multi-level logistische regressiemodellen. De verzamelde data bevatte informatie over 2574 zittingen van 224 patiěnten die werden behandeld door 53 fysiotherapeuten. Het gemiddelde aantal zittingen per behandelepisode was $11,5(\mathrm{sd}=7,8)$, variërend van 3 tot 34 . Drieënvijftig procent van de patiēnten werden behandeld in 9 of minder zittingen. Van de patiëntkenmerken bleek alleen de leeftijd van de patiēnt samen te hangen met een hogere kans op meer dan 9 zittingen per behandelepisode. Van de fysiotherapeut- en praktijkkenmerken waren de leeftijd van de fysiotherapeut (indicatie van de mate van ervaring), de verbijzonderingen manuele therapie en kinderfysiotherapie en het aantal collega's belangrijke determinanten voor het benodigde aantal zittingen per behandelepisode. De resultaten tonen aan dat omvang van de behandeling (in aantal zittingen per behandelepisode) voor een belangrijk deel wordt bepaald door fysiotherapeut- en praktijkkenmerken en in mindere mate dan verwacht door kenmerken van de patiënt. Deze bevinding dient nader onderzocht te worden in vervolgonderzoek, waarbij andere kenmerken van de fysiotherapeut (zoals attitude en aanvullende scholing) moeten worden toegevoegd om meer inzicht te krijgen op de invloed van fysiotherapeutkenmerken in de variatie in het aantal zittingen per behandelepisode.

\section{Deel IV: Discussie}

In het laatste hoofdstuk van de thesis (hoofdstuk 10), worden de belangrijkste bevindingen van het onderzoek samengevat en besproken met het oog op het toekomstige beleid. Tevens worden de methodologische beperkingen van het onderzoek en ethische aspecten nader beschouwd. Vervolgens wordt ingegaan op de gevolgen van het onderzoek voor het gezondheidszorgbeleid, de eerstelijnsgezondheidszorg en toekomstig onderzoek. Tot slot wordt een aantal richtlijnen gegeven en worden aanbevelingen gedaan voor een mogelijke invoering van het $\mathrm{CFO}$ in de eerstelijnsgezondheidszorg. 


\section{References}

Akpala CO, Curran AP, Simpson J. Physiotherapy in general practice: patterns of utilization. Public Health 1988:102:263-268.

American Board of Internal Medicine. A statement on the generalist physician from the American Boards of family practice and internal medicine. JAMA 1994;271:315-16.

American Physical Therapy Association (APTA). Guide to physical therapist practice. Phys Ther 1997:77:1163-1650.

American Thoracic Society (ATS). Standards for the diagnosis and care of patients with chronic obstructive pulmonary disease. ATS statement. Am J respir Crit Care Med 1995;152:S77-S120.

Anderson J, Campbell SK. Correlates of physician utilization of physical therapy. International Journal of Technology Assessment in Health Care 1992:8:10-19

Anke AG, Stanghelle JK. Finset A, et al. Long-term prevalence of impairments and disabilities after trauma. J Trauma 1997:42:54-61.

Anoniem. Veel mensen vinden baat bij fysiotherapie. Consumentengids 1992;10:640-643

Anoniem. Patiêntenvoorlichting kan klantvriendelijker. Consumentengids 1995:3:174-175.

Armitage P, Berry G. Statistical methods in medicall research (2nd ed). Oxford: Blackwall Scientific Publications, 1987.

Armstrong D, Briten N, Grace J. Measuring general practitioner referrals: patient, workload and list size effects. JR Coll Gen Pract. 1988;38:494-97.

Ashburn A, Partridge C, Souza de L. Physiotherapy in the rehabilitation of stroke. Clinical Rehabilitation 1993;7:337-345.

Assendelft WJJ, Rikken SAJJ, Mel M, et al. NHG-Standaard Epicondylitis. Huisarts Wet. 1997:40:21-26.

Atis. Werken aan samenwerken: het initièren van multidisciplinaire samenwerking in de eerstelijnszorg. Bunnik, 1988.

Avant RF. Psychiatric consultation and referral. Medical Clinics of North America 1988;72:929-35.

Avenarius W, Heijnen AM, Kloosterman HM, Wigersma L. De AIDS-consultatielijn voor huisartsen. Medisch Contact 1991:46:1212-1214.

Baar van ME, Dekker J, Kool van Langenberghe: HV. Medisch specialist en fysiotherapeut. Informatieoverdracht naar de eerste lijn. Medisch Contact 1993;48:851-853.

Baar van ME. Dekker J, Oostendorp RAB, et al. The effectiveness of exercise therapy in patients with osteoarthritis of knee or hip: a randomized clinical trial. J Rheumatol 1998;25:2432-2439.

Baar van M. Effectiveness of exercise therapy in osteoarthritis of the hip or knee [PhD Thesis]. Utrecht: Nederlands. Instituut voor onderzoek van de gezondheidszorg (Nivel), 1998

Baar van ME, Dekker J, Bosveld W. A survey of physical therapy goals and interventions for patients with back an knee pain. Phys. Ther 1998;78:33-42:

Baar van ME, Assendelft WJJ, Dekker J. Oostendorp RAB, Bijlsma JWJ. Effectiveness of exercise therapy in patients with osteoarthritis of the hip or knee: a systematic review of randomised clinical trials. Arthritis Rheum 1999:42(7):1361-1369.

Bahrami J, Hamid Husain M, Clifton S, Pringle M, Hill FE, Richards DWL. Access to physical therapy services. BMJ 1983;287:25-28. 
Bakker de DH. Substitutie van tweedelijnszorg door fysiotherapeuten en eerstelijnssamenwerking. Utrecht: Nivel (intern rapport), 1993.

Bakx VEM, Oostendorp RAB, Elvers JWH, et al. Pijnmeting in de fysiotherapie. Een betrouwbaarheidsonderzoek. Ned Tijdschr Fysiother 1993;2:60-67.

Barnsley L, Lord S, Bogduk N. Clinical review whiplash injury. Pain 1994;58:283-307.

Barrow HS, Feltovich PJ. The clinical reasoning process. Med Educ 1987;21:86-91.

Battié MC, Cherkin DC, Dunn R et al. Managing low back pain: attitudes and treatment preferences of physical therapists. Phys Ther 1994;74:101-115.

Beckerman $\mathrm{H}$, Bouter L (eds). Effectiviteit van fysiotherapie: een literatuur onderzoek. Maastricht: Rijksuniversiteit Limburg, 1991.

Beckerman H, Bouter LM, Heijden van der GJMG, Bie de RA, Koes BW. Efficacy of physiotherapy for musculoskeletal disorders: what can we learn from research? B J Gen Pract 1993;43:73-77.

Beek M, Eijk van J, Rutten G. Verschuivingen van eerste naar tweede lijn? Opvattingen van huisartsen en specialisten. Medisch Contact 1985;40:299-302.

Bekkering GE, Hendriks HJM, Chadwick-Straver RVM, et al. KNGF-richtlijn COPD. Ned Tijdschr Fysiother 1998;108: supplement no. 3.

Bekkering GE, Hendriks HJM, Paterson WJ, et al. Guidelines for the physiotherapeutic management in chronic obstructive pulmonary disease (COPD). Phys. Ther. Rev. 2000;5:59-74.

Bekkering GE, Hendriks HJM, Lanser K, Oostendorp RAB, Peeters GGM, Verhagen AP, Windt van der DAWM. KNGF-richelijn. Whiplash. Amersfoort: KNGF/NPi, 2000.

Bekkering GE, Hendriks HJM, Koes B, Oostendorp RAB, Ostelo RWJG, Thomassen J, Tulder van MW, KNGF-richtlijn Lage Rugklachten. Amersfoort: KNGF/NPi, 2000.

Bensing JM, Kluver R, Schut H, Verhaak P. Consultatieproject Eindhoven, eindevaluatie. Utrecht: NHI. 1980.

Bensing JM, Kerssens J., Pasch van der M. Patient-directed gaze as a tool for discovering and. handling psychosocial problems in general practice. Journal of Nonverbal Behavior 1995;19:223242.

Berg van de J. Lankhorst GJ. Inter-rater and intra-rater reliability of disability ratings based on the modified D code of the ICIDH. Int Disabil Stud 1990;12:20-21.

Berghmans LCM, Hendriks HJM, Bo K, et al. Conservative treatment of stress urinary incontinence in women: a systematic review of clinical trials. Br J Urol 1998;82:181-191.

Berghmans LCM, Bernards ATM, Bluyssen AMWL, et al. KNGF-richtlijn Stress-incontinentie. Ned, Tijdschr Fysiother 1998: 108: supplement no. 2.

Berghmans LCM, Bernards ATM. Hendriks HJM, Bo K. Grupping MHM. Guidelines for the physiotherapeutic management of genuine stress incontinence. Phys. Ther. Rev. 1998;3:133-147.

Berghmans LCM. Hendriks HJM. Bie de RA, et al. Conservative treatment of urge urinary incontinence in women: a systematic review of clinical trials. Br J Urol 2000:85:254-263.

Bergsma J. Huisarts en Oncologische consultatie. Huisarts Wet 1984;27:370-372.

Bernards ATM. Schets voor een theoretisch kader fysiotherapie [Lustrum-symposium]. Amersfoort: SWSF, 1989

Bernards ATM, Hagenaars LHA, Oostendorp RAB, Wams HWA. Het meerdiemsionale belastingbelastbaarheidsmodel: een conceptueel model voor de fysiotherapie. Ned. Tijdschr Fysiother 1999; 109:58-65.

Bernards JA. Bouwman LN. Fysiologie van de mens. Houten/Zaventem: Bohn Stafleu Van Loghum, 1994.

Bersee APM, Pluimakers WHMA. De Wet BIG: de betekenis van de nieuwe wetgeving voor beroepsbeoefenaren in de gezondheidszorg. Vermande: Lelystad, 1993.

Bertels M, Brummeler ten L, Dijkum van C, Giebels R、 Mannen van der J. Tijd voor kwaliteit: evaluatie-onderzoek fysiotherapie in gezondheidscentra in Amsterdam. Amsterdam: SISWO, 1985. 
Beurskens AJHM, Vet de HCW, Koke AJA, et al. Efficacy of traction for non-specific low back pain; 5-week results of a rondomized clinical trial. Lancet 1995;346:1596-1616.

Bie de RA. Methodology of systematic reviews: an introduction. Phys. Ther. Rev, 1996:1:47-51.

Bie de RA, de Vet HCW, Lenssen T. The prognosis of ankle sprains. Int J Sports Med 1997;18:285. 289.

Bie de RA, Hendriks HJM, Lenssen AF, et al. KNGF-richtlijn Acuut Enkelletsel. Ned Tijdschr Fysiother 1998;108: supplement no. 1 .

Bie de RA, Verhagen AP, Lenssen AF, et al. Efficacy of $904 \mathrm{~nm}$ laser therapy in musculoskeletal disorders: a systematic review. Phys. Ther. Rev. 1998;3:59-72.

Bie de RA, Verhagen AP, Lenssen AF, et al. Efficacy of conservative interventions in the treatment of acute lateral ankle sprains: a systematic review. In: de Bie RA. Efficacy of $904 \mathrm{~nm}$ laser therapy in acute lateral ankle sprains [PhD Thesis]. Maastricht: Datawyze/Maastricht University Press, 1998.

Bie RA. Efficacy of $904 \mathrm{~nm}$ laser therapy in acute lateral ankle sprains (PhD Thesis). Maastricht: Datawyze/Maastricht University Press, 1998.

Bie de RA, Hendriks HJM, Lenssen AF, et al. KNGF-richtlijn Acuut Enkelletsel. Ned Tijdschr Fysiother 1998;108: supplement no. 1.

Bie de RA, Verhagen AP. De relevantie van effectonderzoek in de fysiotherapie. In: SmitsEngelsman, Ham van 1, Aufdemkampe G, Dekker den JB, Vaes P (eds). Jaarboek Fysiotherapie/Kinesitherapie, pp 1-15. Bohn Stafleu Van Loghum: Houten/Diegem, 1998.

Bigos S, Bowyer O, Braen G, et al. Acute low back problems in adults. Clinical Practice Guideline no. 14. AHCPR Publication no. 95-0642. Rockville, MD: Agency for Health Care Policy and Research, Public Health Services, U.S. Department of Health and Human Services, 1995.

Bindman $\mathrm{AB}$, Keane $\mathrm{D}$, Lurie $\mathrm{N}$. Measuring health changes among severely ill patients. Med Care $1990 ; 28: 1142-52$.

Bjordal JM, Greve G. What may after the conclusions of reviews? Phys. Ther. Rev. 1998:3:121-132.

Bo K. Stress urinary incontinence, physical activity and pelvic floor muscle strength training (review article). Scand J Med Sci Sports 1992;2:197-206.

Bo K. Physiotherapy to treat genuine stress incontinence. Int Cont Surv 1996;1:2-8.

Boer den F, Hageman GCHA, Waal MWM, Peri H. Het gezamenlijk consult in de eerste lijn. Een alternatief voor het verwijzen naar de tweede lijn? Medisch Contact 1996;51:221-223.

Bonsema K. Boutens EJ, Kaiser V. Stoffers HEJH. NHG-Standaard Perifeer Arterieel Vaatiijden. Huisarts Wet 1990:33:440-446.

Borst-Eijlers E. Voortgangsrapportage MTA en doelmatigheid van zorg (Progress report on MTA and efficiency on care). April 2, 1997.

Bosch van den WJHM, Coumans RHM, Verkerk S, Weert van H. NHG-Standaard Enkeldistorsie. Huisarts Wet 1989;32:523-526.

Bouter LM, Dongen van MCJM. Epidemiologisch onderzoek: opzet en interpretatie. Utrecht: Bohn, Scheltema en Holkema, 1988.

Bouter LM, Beckerman H. Heijden van der GMJG, Koes BW, Bie de RA. Effectiviteit van. fysiotherapie; een samenvatting van 9 meta-analyses. Ned Tijdschr Geneeskd 1992;136:1058-1061.

Bouter LM. Improving the quality of clinical trials in physical therapy. In: Dekker J, Oostendorp RABi (eds). Improving the quality of physical therapy: invited lectures. Utrecht / Amersfoort: Netherlands; institute of primary health care (Nivel) / Dutch national institute for the allied health professions. (NPi), 1995.

Bowler Hulme J, Wackernagel B, Lewis JW. Communication between physicians and physical therapists. Phys Ther 1988;68:26-31.

Braak E. Lange de L. Cleton-van de Dikkenberg E. Een geriatrisch consultatiepunt voor huisartsen. Medisch Contact 1989:44:717-19.

Braak E, Lange de L. Van geriatrisch consultatiepunt voor huisartsen naar vakgroep Geriatrie Gerontologie. Een Utrechts experiment. Medisch Contact 1993:29/30:908-910. 
Brandsma JW, Heerkens YF, Ravensberg van CD. The International Classification of Impairments, Disabilities, and Handicaps (ICIDH): a manual of classification relating to the consequences of disease? J Rehab Sciences 1995;8:2-7.

Brandsma JW, Robeer GG, Heuvel van den S, et al. Effect of exercises on walking distance of patients with intermittent claudication: study of randomized clinical trials. Phys Ther 1998;78:278288.

Brink-Muinen A, Dekker J. Na- en bijscholing van fysiotherapeuten in de eerste lijn. Een onderzoek naar het aanbod van zorg. Utrecht: Nivel, 1991.

Brouwer W. Het eenmalig geriatrisch consult. Huisarts Wet 1983;26:140-44.

Bryk AS, Raudenbusch SW. Hierarchical Linear Models: applications and data management methods. Newbury Park: Sage publications, 1992.

Buis WJMN. Psychiatrische diagnsotiek en advies ten dienste van de huisarts. Amsterdam (Dissertatie): Uitgeverij Thesis, 1994

Bury T. The status and development of physiotherapy research in the United Kingdom. Phys. Ther. Rev. 1997:2:165-171.

Cambach W, Wagenaar RC, Koelman TW, Keimpema van ARJ, Kemker HCG. The long-term effects of pulmonary rehabilitation in patients with astma and chronic obstructive pulmonary disease: a research synthesis. Arch Phys Med Rehabil 1999;80:103-111.

Campbell SK, Anderson JC. Gardner HG. Use of survey research methods to study clinical decision making: referral to physical therapy of children with cerebral palsy. Phys Ther 1992; 69:610-615.

Carey T, Evans A, Hadler N, et al. Acute severe low back pain: a population-based study of prevalence and care-seeking. Spine 1996:21:339-344.

Carey T, Garrett J, Jackman. A, et al. The outcomes and costs of care for acute care low back pain among patients seen by primary care providers, chiropractors andi orthopedic surgeons. N Engl J Med 1995;333:913-917.

Carne S. A problem halved? JRoyal Coll Gen Pract 1982;32:10-31.

Centraal Bureau voor de Statistick. Statistisch zakboek. s' Gravenhage: CBS, 1991.

Centraal Bureau voor de Statistiek. Vademecum Gezondheidsstatistiek. s` Gravenhage: CBS, 1992.

Centraal Bureau voor de Statistiek (CBS). Statistisch jaarboek 1993. 's Gravenhage: Staats-uitgeverij. 1994.

Centraal Bureau voor de Statistiek (CBS). Statistisch Jaarboek 1997. Voorburg: CBS, 1998.

Centraal Bureau voor de Statistiek (CBS). Statistisch Jaarboek 1999. Voorburg: CBS, 2000.

Chalmers TC, Smith $\mathrm{H}_{4}$ Blackburn B, et al. A method for assessing the quality of a randomized controlled trial. Controlled Clin Trials 1981;2:31-49.

Chel VGM, Germs PH, Wal van der J, et al. NHG-Standaard Decubitus. Huisarts Wet 1999:42:165-172:

Chiel HJ, Beer RD. The Brain has a body: Adaptive behavior emerges from interactions of nervous sytem, body and environment. Trens Neurosci 1997;20:553-557.

Cichetti DV. Testing the normal approximation and minimal size requirements of weighted kappa when the number of categories is large. Appl Psychol Meas 1981:5:101-104.

Cichetti DV, Feinstein AR. High agreement but low kappa: II. resolving the paradoxes. J Clin Epidemiol 1990:43:551-558.

Cirkel JW, Klaassen WRC, Kunst JA, et al. NHG-Standaard Niet-traumatische Knieproblemen bij Kinderen en Adolescenten. Huisarts Wet 1998;41:246-251.

Cohen J. A coefficient of agreement for nominal scales. Educ Psychol Meas 1960;20:37-46.

Cohen J. Statistical power analysis for the behavioral sciences. Hillsdale: Lawrence Erlbaum Associates, 1988.

College of Family Physicians of Cananda / Royal College of Physicians and Surgeons of Cananda. Relationship between Family physicians and specialist/consultants in the provision of patient care. Canadian Family Physician 1993:39:1309-1312. 
Collijn D, Wijkel D, Feltz-Cornelis van der CM, Verhaak P, Huijse FJ. Psychiatrische consulten bij somatiserende patiēnten in de huisartspraktijk. Een haalbaarheidstudie. Utrecht: Nivel/VU, 1994.

Collijn Th, Kerkstra A. Consultatie bij complexe geriatrische problematiek. Medisch Contact 1994;49:643-645.

Commissie modernisering curatieve zorg. (Biesheuvel BW et al.). Gedeelde zorg: betere zorg [rapport]. Roosendaal: Koninklijke Van Poll, 1994.

Cook TD, Campbell DT. Quasi-experimentation. Design and analysis issues for field settings. Boston: Houghton Mifflin Company, 1979.

Cott CA. Finch E, Gasner D, Thomas SG, Verrier MC. The movement continuum theory of physical therapy. Physiother Canada 1995;47:87-95.

Coulter A, Noone A, Goldacre M. General practitioners' referrals to specialist outpatient clinics! Why general practitioners refer patients to specialist outpatient clinics. BMJ 1989;299:304-308.

Culav EM. Connective tissues: matrix composition and its relevance to physical therapy. Phys Ther 1999;79:308-319.

Cushway D. Understanding stress and coping. Br J Ther Rehabil 1995;2:615-620.

Dale van: Groot woordenboek der Nederlandse taal. Van Dale Lexicografie, 1992.

Dekker J, Baar van ME. Curfs EChr. Kerssens JJ. Diagnosis and treatment in physical therapy; an empirical investigation of their relationship. Phys Ther 1993;73:568-580.

Dekker J, Baar van ME (eds). Beleidsgericht Evaluatie- en Effectonderzoek Extramurale Fysiotherapie 1989-1992. Nederlands instituut voor onderzoek van de gezondheidszorg (Nivel): Utrecht, 1995

Dekker J. Application of the ICIDH in survey research on rehabilitation: the emergence of the functional diagnosis. Disabil Rehabil 1995;17:195-201.

Delitto A. Are measures of function and disability important in low back pain? Phys Ther $1994 ; 74: 452-462$.

Diagnosis in physical therapy: a roundtable discussion. PT-magazine of physical therapy; June 1993:58-65.

Dirksen: WJ, Geijer RMM, Haan de M, et al. NHG-Standaard Astma bij Kinderen. Huisarts Wet 1998;41:130-143.

Driessen MJ, Dekker J, Lankhorst GJ, Zee van der J. Inter-rater and intra-rater reliability of the occupational therapy diagnosis. Occup Ther J Res 1995;15:259-274.

Duncan C, Jones K. Moon G. Health-related behaviour in context: a multilevell modeling approach. Soc Sci Med 1996:42:817-830.

Edwards BC. A physical approach to the rehabilitation of patients with chronic low back pain. Med J Australia 1992;156:168-171.

Elders P. Keimpema van JC. Petri H, et al. NHG-Standaard Osteoporose. Huisarts Wet $1999 ; 42: 115-128$.

Enderby P, Kew E. Outcome measurement in physiotherapy using the World Health Organisation's Classification of Impairment. Disability and Handicap: A pilot study. Physiotherapy 1995;81:177180 .

Evans A. A study of the referral decision in general practice. Fam Pract 1993;10(2):104-110.

Faas A, Chavannes. AW, Koes BW, et al. NHG-Standaard Lage-Rugpijn. Huisarts Wet 1996;39:1831.

Faas A. Exercises: which one's are worth trying, for which patients and when? Spine 1996:21:2874 2878.

Feine JS, Lund JP. An assessment of the efficacy of physical therapy and physical modalities for the control of chronic musculoskeletal pain. Pain 1997;71:5-23.

Feinstein AR. Cichetti DV. High agreement but low kappa: I. The problem of two paradoxes. J Clin Epidemiol 1990:43:543-549. 
Fertig A, Roland M, King H, Moore T. Understanding variation in rates of referral among general practitioners: are inappropriate referrals important and would guidelines help reduce to reduce rates? BMJ 1993;307:1467-1470.

Field MJ, Lohr KN (eds). Guidelines for Clinical Practice. From development to use. IOM, Washington DC, National Academy Press, 1992.

Fleiss JL. Statistical methods for rates and proportions (2nd ed). New York: John Wiley, 1981.

Fockert de JA. De geriatrische polikliniek van een algemeen ziekenhuis. Resultaten van een vernieuwde opzet. Medisch Contact 1985:40:294-296.

Foets $\mathrm{M}$, Velden van der $\mathrm{J}$. Nationale studie naar ziekten en verrichtingen in de huisartsenpraktijk. Basisrapport: Meetinstrumenten en procedures. Utrecht: Nivel, 1990.

Fordyce WE. Behavioural methods for chronic pain and illness. St. Louis: CV Mosby, 1976.

Foster NE. Researching low back pain? An overview of the pitfalls. Phys. Ther. Rev, 1998;3:9-17.

Franks P, Clancy CM, Nutting PA. Gatekeeping revisited-protecting patients from overtreatment. N Engl J Med 1992;327(6):424-29.

Freburger JK. An analysis of the relationship between the utilization of physical therapy services and outcomes for patients with acute stroke. Phys Ther 1999;79:906-918.

Frost H. Randomised controlled trial for evaluation of fitness programme for patients with chronic low back pain. BMJ 1995;310:151-154.

Fujino A, Tokumasu K, Yosio S, et al. Vestibular training of benign paroxysmal positonal vertigo. Its efficacy in comparison with anivertigo drugs. Arch Otolaryngol Head Neck Surgery 1994:120:497-504.

Fung S, Byl N, Melnick M, et al. Functional outcomes: the development of a new instrument to monitor the effectiveness of physiotherapy. European Journal of Medical Rehabilitation 1997:7:3141.

Fysiotherapeutenbesluit. In: Staatsblad van het Koninkrijk der Nederlanden, 1977 no. 432: Besluit van I juli 1977 tot vaststelling, van nieuwe regelen inzake het beroep van fysiotherapeut.

Gadsby JG, Flowerdew MW. The effectiveness of transcutaneous electrical nerve stimulation (TENS) and acupuncture-like transcutaneous elecrical nerve stimulation (ALTENS) in the treatment of patienis with chronic low back pain. The Cochrane Library 1999 Issue 1, pp. 1-35.

Gardner AW, Pochlman ET. Exercise rehabilitation programs for the treatment of claudication pain. JAMA 1995;274:975-80.

Gargan M, Bannister G, Main C, et al. The behavioral response to whiplash injury. J Bone Joint Surg (Br) 1997;79B:523-526.

Geijer RMM, Burgers IS, Laan van der JR, Wiẹrsma TI, Rosmalen CFH. Thomas S [Eds]. NHGStandaarden voor de huisarts, deel 1. Maarssen: Elsevier/Bunge, 1999.

Geijer RMM, Schayck van CP. Weel van, et al. NHG-Standaard COPD: behandeling. Huisarts Wet 1997:40:430-442.

Geijer RMM, Hensbergen van W, Bottema BJAM, et al. NHG-Standaard Astma bij Volwassenen: behandeling. Huisarts Wet 1997:40:443-454.

Gezondheidsraad. De effectiviteit van fysische therapie; electrotherapie, lasertherapie, ultrageluidbehandeling. Den Haag: Gezondheidsraad, 1999.

Gisbergen van MJWM, Dekker J. Reliability of the diagnosis of impairments and disabilities by exercise therapists. J Rehab Sciences 1992;5:67-73.

Gisbergen van MJWM, Dekker J. Zuijderduin W. Reliability of the diagnosis of impairments in survey research in the field of chiropody. Disabil Rehab 1993;15:76-82.

Gloerich ABM, Zee van der J. Determinanten van verwijzen door de huisarts naar de tweedelijn. Deelproject van de Nationale Studie van Ziekten en Verrichtingen in de Huisartsenpraktijk. Utrecht: Nivel, 1992.

Goldby L. Low back pain: the evidence for physiotherapy. Phys. Ther. Rev. 1997:2:7-11.

Goldstein H. Multilevel statistical models. New York: Halsted Press (2 ${ }^{\text {nd }}$ edition), 1995. 
Grace JF, Armstrong D. Referral to hospital: perceptions of patients, general practitioners and consultants about necessity and suitibility of referral. Fam Pract 1987:4:170-175.

Grijn van der D, Wijkel D. Huisarts en Diagnostisch Centrum Oudenrijn. Utrecht: NHi/NZi, 1982.

Grimshaw JM, Russel I. Development and implementation of practice guidelines, Qual Health Care $1995 ; 4: 1317-1322$.

Grinten van der R. Communicatie huisarts-internist. Vier jaar ervaring met consultatie in het gezondheidscentrum Withuis. Medisch Contact 1981;36:777-781.

Groenewegen. PP. Hingstman L, Dekker J. Gebruik en beschikbaarheid van fysiotherapeutische zorg in de toekomst. Ned Tijdschr Fysiother 1990;100:84-91.

Grundmeijer HGLM. Brouwer HJ. De betekenis van fysiotherapie bij aandoeningen van het bewegingsapparaat. Huisarts Wet 1988:31:44-50.

Grundmeijer HGLM, Weert van HCPM, Brouwer HJ. Wat is goed verwijzen en kan het beter? Een literatuuronderzoek. Huisarts Wet 1996:39:113-119.

Guccione AA. Physical therapy diagnosis and the relationship between impairments and function. Phys Ther 1991:71:499-504.

Haaften van KL, Schuringa-de Boer WJ. Analyse van vijf samenwerkingssituaties. In: Greve WB de [red.]. Samenwerking ziekenhuis en eerstelijn; pag. 7-35. Alphen aan den Rijn: Stafleu, 1983. Serie: Leiding \& organisatie in de gezondheidszorg: een reeks kwartaalschriften.

Haan de EA, Dijk van JP. Hollenbeek Brouwer J. Mening van cliēnten over de kwaliteit van fysiotherapie. Ned Tijdschr Fysiother 1995;1:18-22.

Hageman GCHA, Jansen HDM. Een voorbeeld van samenwerken in de verloskunde. Huisarts Wet $1984 ; 27: 456-457$.

Hall van EV, Gill K, Trimbos JB. Gynaecologische consultaties in de huisartspraktijk. Medisch Contact 1987;42:105-106.

Hart E, Pinkston D. Ritchey FJ, Knowles CJ. Relationship of professiona! involvement to clinical behaviors of physical therapists. Phys Ther 1990;70:179-87.

Harteloh PPM. Verweij GCC. Gezondheidsenquete, de mening van tevredenheid over huisarts, tandarts, fysiotherapeut en specialist. Maandbericht. gezondheidsstatistiek, 1995;14:4-18.

Have ten JJIM, Kolker L. Consultatievormen tussen huisarts en specialist. Utrecht: Stichting O\&O, 1990.

Hays RD, Ware JE. My medical care is better than yours: social desirability and patient satisfaction ratings. Med Care 1986; 24(6): 519-524.

Hedel van H. Het Consultatief Fysiotherapeutisch Onderzoek (CFO) in de Eerste Lijn. Patiēntkenmerken, prognose en resultaat van fysiotherapie van patiënten die na een $\mathrm{CFO}$ zijn verwezen voor fysiotherapie. Nederlands Paramedisch Instituut (NPi) - Katholieke Universiteit Nijmegen (KUN): Amersfoort/Nijmegen, 1998.

Heerkens YF, Brandsma JW, Ravensberg van CD. Proposals for adaptation of the Classification of Impairments and the Classification of Disabilities of the ICIDH from the perspective of five Dutch health professions. Zoetermeer, the Netherlands: Nationale Raad voor de Volksgezondheid/WHO Collaborating Centre for the ICIDH; 1993.

Heerkens YF, Brandsma JW, Bernards ATM, Hendriks HJM, Lakerveld-Heyl K, Ravensberg van CD, Wams HWA, Oostendorp RAB. Helders PJM. Zin en onzin van het gebruik van de ICIDH. Fysiopraxis 1993;18:18-21.

Heerkens YF, Brandsma JW, Lakerveld-Heyl K, Ravensberg van CD. Impairments and disabilities The difference. Proposal for Adjustment of the International Classification of Impairments, Disabilities, and Handicaps. Phys. Ther 1994:74:430-442.

Heerkens Y. Heuvel van den H, Klaveren van T, Ravensberg van CD. Voorlopige Classificatie Verrichtingen Paramedische Beroepen. Amersfoort: Nederlands Paramedisch Instituut (NPi), 1995. 
Heerkens YF, Vogels EMHM, Wiarda VL, Ravensberg van CD, Heerkens YF, Vogels EMHM, Wiarda VL, Ravensberg van CD. Verslag van het onderzoek: fysiotherapeutische: diagnose. Amersfoort: KNGF/NPi, 1997.

Heerkens YF, Heuvel van den J, Klaveren van AAJ, Ravensberg van CD. Ontwerp Classificatie Medische Termen (CMT) voor Paramedische Beroepen. Amersfoort: Nederlands Paramedisch Instituut (NPi), 1998.

Heijden van der GJMG, Beurskens AJHM, Koes BW, et al. The efficacy of traction for back and neck pain: a systematic blinded review of randomized clinical trial methods. Phys Ther 1995;75:93-104.

Heijden van der. Shoulder disorder treatment. Efficacy of ultrasoundtherapy and electrotherapy [PhD thesis]. Maastricht: Datawyse / Maastricht University Press, 1996.

Heijden van der, Windt van der DAWM, Winter de AF. Physiotherapy for soft-tissue shoulder disorders: a systematic review of randomized clinical trials. BMJ 1997;315:25-30.

Hendriks HJM, Wagner C. Brandsma JW, et al. Het consultatief fysiotherapeutisch onderzoek (CFO) in de eerste lijn. Informatie uit de literatuur en introduktie van het CFO-project. Ned Tijdschr Fysiother 1992:6:176-183

Hendriks HJM, Brandsma JW, Wagner C, Dekker J. Het Consultatief Fysiotherapeutisch Onderzoek (CFO) in de eerste lijn. Eindverslag Fase 1. Amersfoort: SWSF, 1992.

Hendriks HJM. Consultatie van de fysiotherapeut. Een middel voor een betere samenwerking tussen huisartsen en fysiotherapeuten. Jaarboek Fysiotherapie 1993. Houten: Bohn, Stafleu van Loghum. 1993

Hendriks HJM, Brandsma JW, Wagner C, Dekker J, Oostendorp RAB. Eerste ervaringen met het consultatief fysiotherapeutisch onderzoek. Ned Tijdschr Fysiother 1993:103:190-2000.

Hendriks HJM, Wagner C. Dekker J, Brandsma JW. Evaluatie van het consultatief fysiotherapeutisch onderzoek in de eerste lijn. Resultaten van een veldexperiment. Utrecht: Nivel, 1994.

Hendriks HJM, Wagner C, Brandsma JW, et al. Experiences with physiotherapsist's consultation. Results of a feasibility study. Physiother Theory Prac. 1996:12(4):211-220.

Hendriks HJM, Reitsma E, Ettekoven van H. Centrale Richtlijnen in de fysiotherapie: introductie van het Centrale Richtlijnen (CR)-project. Ned Tijdschr Fysiother 1996;106(1):2-11.

Hendriks HJM, JW Brandsma, YF Heerkens, RAB Oostendorp, RM Nelson. Intra- and interobserver reliability of the assessment of the functional health status in physical therapy. Phys Ther 1997:77:1097-1106.

Hendriks HJM, Ettekoven van H. Reitsma E, Verhoeven A, Wees van der Ph. Methode voor centrale richtlijnontwikkeling en implementatie in de fysiotherapie. Amersfoort/Utrecht: KNGF/CBO/NPi, 1998.

Hendriks HJM, Ettekoven van H. Reitsma E, Wees van der Ph. Eindverslag van het project Centrale Richtijnen (CR) in de Fysiotherapie. Deel I: achtergronden en evaluatie van het project. Amersfoort/Utrecht: $\mathrm{KNGF/CBO/NPi,} 1998$

Hendriks HJM, Bekkering GE, Brandsma JW, et al. Development and implementation of national practice guidelines: a prospect for continuous quality improvement in physiotherapy. An introduction to the method of guideline development (Part I). Physiotherapy 2000;86:535-547.

Hendriks HJM, Kerssens JJ, Dekker J, Oostendorp RAB, Zee van der J, Neison RM. Physical therapist consultation in general practice: its use and impact on the process of care. Phys Ther (accepted)

Hendriks HJM. Kerssens JJ. Bekkering GE, et al. Patterns of utilization and efficiency of care of physiotherapist consultation in general parctice. Physiother Theory Prac (accepted).

Hendriks HJM, Oostenđorp RAB. Bernards ATM, Ravensberg van CD. Heerkens YF, Nelson RM. The diagnostic process and indication for physiotherapy: a prerequisite for treatment and outcome evaluation. Phys. Ther. Rev. 2000:5:29-47.

Hendriks HJM, Ettekoven van H, Bekkering GE, Verhoeven A. Implementatie van KNGF richtlijnen: van theorie naar praktijk. Fysiopraxis 2000:9:9-13. 
Hendriks HJM, Bie de RA, Zee van der J. Consultation between General Practitioners and medical consultants. What do we know from the literature? (submitted).

Hendriks HJM, Kerssens JJ, Bekkering GE, Dekker J, Oostendorp RAB, Zee van der J. Determinants of the number of sessions per physiotherapy treatment episode (submitted).

Heugten CM, Sluijs EM, Dekker J. Programmering van onderzoek naar doelmatigheid van paramedische zorg: een verkennende studie. Utrecht: Nivel, 1995

Heuvel van den C. De kwaliteit van de werkrelatie met fysiotherapeuten. De Huisarts 1991;10:22-24. Heuvel van den. Samenwerking huisarts-fysiotherapeut. Bijblijven 1996;12:66-72.

Higgs J. Jones M. Clinical reasoning. In: Higgs J, Jones M (eds): Clinical reasoning in the health professions. London: Butterworth-Heineman, 1995.

Higgs J, Titchen A. Research and Knowledge. Physiotherapy 1998;84:72-80.

Hingstman L, Harmsen J. Beroepen in de extramurale gezondheidszorg 1994. Aanbod van beroepsbeoefenaren en samenwerkingsverbanden in de extramurale gezondheidszorg in de periode 1980-1993. Utrecht, De Tijdstroom/Nivel, 1994.

Hochberg MC. Altman RD. Brandt KD, et al. Guidelines for the medical management of osteoarthritis. Part I. Osteoarthritis of the hip. Arthritis Rheum 1995:38:1535-1540.

Hochberg. MC, Altman RD, Brandt KD, et al. Guidelines for the medical management of osteoarthritis. Part II. Osteoarthritis of the knee. Arthritis Rheum 1995;38:1541-1546.

Hope $\mathrm{Ph}$, Forshaw MJ. Assessment of psychological distress is important in patients presenting with low back pain. Physiotherapy 1999;85:563-570.

Hopman-Rock M. Coping with osteoarthritis of the knee and/or hip: the development of a lifestyle programme. TNO Preventie en gezondheid: Leiden. (The Netherlands), 1994

Hornberger JC, Habracken MA, Bloch DA. Minimum data needed on patient preferences for accurate efficient decision making. Medical Care 1995; 33:297-310.

Hulka B. Wheat JR. Patterns of utilization: the patient perspective. Medical Care 1985;23:438-460.

Hulme JB, Wackernagef B, Lewis JW, Communication between physicians and physical therapists. Phys Ther 1988;68:26-31.

Jaarboek Ziekenhuizen. Utrecht:SIG/Informatiecentrum voor de gezondheidszorg, 1992.

Jacobs HM, Melker de RA, Touw-Otten FWMM. Samenwerking tussen huisartsen en specialisten (I). Medisch Contact. 1983;38:1599-1601.

Jacobs HM, Melker de RA, Touw-Otten FWMM. De taakafbakening van het professionele handelen tụssenhuisartsen en specialisten. In: van Es et al. [red.]. Het Medisch Jaar 1984; pag: 50-58.

Utrecht/Antwerpen: Bohn, Scheltema \& Holkema, 1985.

James G. Editorial = The clinical reasoning process. Brit J Ther Rehab 1999;6(8):368.

Jelles F, Bennekom van CAM, Lankhorst GJ "et al. Inter- and intra-rater agreement of the rehabilitation activities profile. J Clin Epidemiol 1995:3(48):407-416.

Jette AM. Diagnosis and classification by physical therapists. Phys Ther 1989;69:967-969:

Jette AM, Smith K, Haley SM, Davids KD. Physical therapy episodes of care for patients with low back pain. Phys Ther 1994;74:101-115.

Jette AM. Physical disablement concepts for physical therapy research and practice. Phys Ther 1994;74:380-386.

Jette AM. Outcomes research: shifting the dominant research paradigm in physical therapy. Phys Ther 1995:75:965-970

Jette AM, Jette DU. Physical therapy and health outcomes in patients with spinal impairments. Phys Ther 1996;76:930-941.

Jette AM. Delitto A. Physical therapy treatment choices for musculoskeletal impairments. Phys Ther 1997:77:145-154.

Jette DU, Jette AM. Professional uncertainty and treatment choices by physical therapists. Arch of Physical Medicine and Rehabilitation 1997;78:1346-1351 
Jette D, Manago D, Medved E, Nickerson A, Warzycha T, Bourgeois MC. The disablement process in patients with pulmonary disease. Phys Ther 1997;77:385-394.

Johnston M. Models of disability. Physiother Theory Prac 1996;12:131-141.

Joint Working Party of the Welsh Council of the Royal College of General Practitioners and the Welsh General Medical Services Committee. Patient care and the general practitioner. BMJ 1994;309:114447.

Jones K. Moon G. Multilevel assessment of immunisation uptake as aperformance measure in general practice. BMJ 1991:303:28-31.

Jones M. Clinical reasoning: the foundation of clinical practice. Part 2. Australian Physiotherapy 1997:43:213-217

Joosten JA, Daams J, Knottnerus JA. Verwijzingen naar de internist: een vergelijkend retrospectief panelonderzoek naar de kwaliteit van verwijzingen van huisartsen die veel en huisartsen die gemiddeld naar de internist verwijzen. Medisch Contact 1990;45:83-85.

Kankaanpaa M. Taimela S, Airaksinen O, Hanninen O. The efficacy of active rehabilitation in chronic low back pain. Spine (in press).

Kankaanpaa M. Lumbar muscle endurance in the assessment of physical performance capacity of low back pain patients [PhD thesis]. Kuopio: Kuopio University Publications, 1999.

Kassirer JP. Incorporating patients' preferences into medical decisisons. N Engl J Med 1994;330: 1895-1896

Katon W, Korff von M, Lin E, Simon G, Walker E, Unutzer J, Bush T, Russo J, Ludmann E. Stepped collaborative care for primary care patients with persistent symptoms of depression: a randomized trial. Arch Gen Psychiatry 1999:56:1109-1115.

Katon W, Gonzales J. A review of randomized trials of psychiatric consultation-liaison studies in primary care. Psychosomatics 1994;35:268-278.

Kerssens JJ, Groenewegen PP. Referrals to physiotherapy: the relation between the number of referrals, the indication for referral and the invlination to refer. Soc Sci Med 1970;30(7):797-804.

Kerssens JJ, Curfs EChr. Extramurale fysiotherapie. Utrecht: Nivel, 1993 (Dissertation University of Utrecht).

Kerssens JJ, Sluijs WM, Verhaak PFM, Knibbe HJJ, Hermans IMJ. Back care instructions in physical therapy: a trend analysis of individualized back care programs. Phys Ther 1999;79:286-295.

Kersten TJJMT. De invloed van de huisarts op de specialist. Een theoretische analyse getoetst aan de opvattingen van huisartsen. TSG 1992;70:171-179.

Keuzevrijheid en keuzemogelijkheden voor patiënten in het zorgstelsel. Utrecht: Zoetermeer: NP/CF en RVZ, 1997

Kiecolt-Glaser JK, Marucha PT, Malarkey WB, Mercado AM, Glaser R. Slowing of wound healing by psychological stress. Lancet 1995;346:1194-96.

Kiecolt-Glaser JK, Glaser R. Psychoneuroimmunology and health consequences: data and shared mechanisms. Psychosomat Med 1995;57:269-274.

Klaveren van AA, Ravensberg van CD, Oostendorp RAB, Hendriks HJM, Elvers JWH. Basisregistratie Fysiotherapie. Een inventarisatie van het fysiotherapeutisch handelen in de eerste lijn. Amersfoort: Nederlands Paramedisch Instituut (NPi), 1995.

Kloot van der WA, Oostendorp RAB, Meij van der J, Heuvel van den J. De Nederlandse versie van 'McGill pain questionnaire' : een betrouwbare pijnvragenlijst. Ned Tijdschr Geneeskd 1995;139:669673.

KNGF (Koninklijk Nederlands Genootschap voor Fysiotherapie). Richtlijnen voor de fysiotherapeutische verslaglegging. KNGF: Amersfoort, 1993.

Knotnerus JA, Joosten J. Daams J. Comparing the quality of referrals of general practitioners with high and average referral rates: an independent panel review. Br J Gen Pract 1990;40:178-181.

Knottnerus JA, Metsemakers JFM. Chronische ziekte in de huisartspraktijk: prevalentie. multimorbiditeit, sociale prevalentie. Huisarts Wet 1996:39:494-497. 
Koes BW, Bouter LM, Heijden van der GJMG. Methodological quality of randomized clinical trials on treatment efficacy in low back pain. Spine 1995:20:228-235.

Koes BW, Assendelft WJJ, van der Heijden GJMG, Bouter LM. Spinal manipulation for low back pain. An updated systematic review of randomized clinical trials. Spine 1996:21:2860-2873.

Koes BW. Editorial - Now is the time for evidence based physiotherapy. Physiotherapy Research International 1997:2:iv-v.

Kuyvenhoven MM, Pieters HM, Jacobs HM, Touw-Otten FWMM, Spreeuwenberg C. From no consultation to peer review. Scand J Prim Health Care 1988;6:5-12.

Kuyvenhoven MM, Pieters HM, Jacobs HM, Touw-Otten, Spreeuwenberg C. Do peer consultations improve quality of care in general practice? Quality Assurance in Health Care 1990;2:171-179.

Kuyvenhoven MM, Pieters HM, Jacobs HM, Touw-Otten, Spreeuwenberg C. Gezondheidscentra springen er in gunstige zin uit. Medisch Contact 1991;46:51-54.

Kwakkel G. Wagenaar RC, Koelman TW, et al. Effects of intensity of stroke rehabilitation. A research synthesis. Stroke 1997;28:1550-1556.

Kwakkel G. Dynamics in functional recovery after stroke [PhD Thesis]. Amsterdam: Ponsen \& Looijen BV, 1998.

Kwakkel G, Wagenaar RC. Twisk JWR, Lankhorst G. Koetsier JC. Intensity of leg and arm training after primary middle-cerebral-artery stroke: A randomised clinical trial. Lancet 1999;354:191-196.

Kwakkel G, Kollen BJ, Wagenaar RC. Therapy impact on functional recovery in stroke rehabilitation. A critical review of the literature. Physiotherapy 1999:85:377-391.

Kwaliteit van zorg. Verhandelingen van de Tweede Kamer, vergaderjaar 1990-1991, 22 113, nrs. 1-2.

Kwaliteit in beeld. Special Kwaliteitsconferentie en Leidschendamafspraken. 1995-2000. Zoetermeer: Gezamenlijke uitgave van de NRV en de Geneeskundige Hoofdinspectie, 5e jaargang, nr. 3, blz.3-6. 1995.

Lacasse Y, Wong E, Guyatt GH, et al. Meta-analysis of respiratory rehabilitation in chronic obstructive pulmonary disease. Lancet 1996;348:1115-1119.

Lagro-Janssen ALM, Breedveldt-Boer HP, Dongen van JJAM, et al. NHG-Standaard Incontinentic voor Urine. Huisarts Wet 1995;38:71-80.

Lamberts H, Wood M. International Classification of Primary Care. Oxford: University Press Oxford, 1987.

Lamberts H. In het huis van de huisarts. Verslag van het Transitieproject. Lelystad: Meditekst, 1991 Landelijke Huisartsen Vereniging. Het basistakenpakket van de huisarts. Utrecht: LHV Vademecum, 1987.

Lawrence RH, Jette AM. Disentangling the disablement process. J Gerontol B Psychol Sci Soc Sci 1996; 51:S173-82.

Leemrijse C. Mischner-van, Ravensberg CD, Oostendorp RAB. Een brede inventarisatie van het fysiotherapeutisch zorgverleningsproces in de eerstelijnsgezondheidszorg. Ned Tijdschr Fysiother. 1992;102:208-218.

Leidschendam Conferenties 1989/1990. Afspraken over kwaliteitsbeleid. Vervolgconferentic over kwaliteit van zorg op 14 en 15 juni 1990 te Leidschendam. Zoetermeer: NRV, 1991.

LHV (Landelijke Huisartsen Vereniging), 1987. Het basistakenpakket van de huisarts. LHV Vademecum: Utrecht, 1987.

Lindström I, Ohlund C, Eek C, et al. The effect of graded activity on patients with subacute pain: a randomized prospectieve clinical study with an operant behavioural approach. Phys Ther 1992:72:279-290.

Linton SJ, Hallden K. Can we screen for problematic back pain? A screening questionnaire for predicting outcome in acute and sub-acute back pain Clinical Journal of Pain 1998:14:200-215.

Lisdonk van de FH. Schellevis FG. Interdoktervariatie en de kwaliteit van verwijzen. Een literatuuronderzoek. Huisarts Wet 1994;37:573-578. 
Locht HPJ, Beusmans GHMI, Pop P. Het gestructureerde telefonisch consult. Werkelijkheid versus wenselijkheid. Medisch Contact 1994:49:608-610.

Lubeck DP. The economic impact of arthritis. Arthritis Care Res 1995:8:304-310.

MacIntyre DL, McAuley CA, Parker-Taillon D. Canadian physiotherapy research and evidence-based practice initiative in the 1990s. Phys. Ther. Rev. 1999;4:127-137.

Magistro CM. Clinical decision making in physical therapy. A Practitioner's perspective. Phys Ther 1989;69:525-534.

Main CJ, Watson PJ. Screening for patients at risk of developing chronic incapacity. Journal of Occupational Rehabilitation 1995:5:207-217

Marshall JB. How to make consultations work? Postgraduate Medicine 1988;84:253-257.

May B, Dennis JK. Expert decision making in physical therapy. A survey of practitioners. Phys Ther 1991;71:190-202.

McCarthy ML, Ewashko T, MacKenzie EJ. Determinants of use of outpatient rehabilitation services following upper extremity injury. Journal of Hand Therapy 1998;11:32-38.

McDonough SM. The neurophysiological basis of reciprocal inhibition in man. Phys. Ther. rev. 1997;2:19-28.

McKegney FP, Beckhardt RM. Evaluative research in consultation-liaison psychiatry. General Hospital Psychiatry, 1982;4:197-218.

McPhee SJ, Lo B, Saika Y, Meltzer R. How good is communication between primary care physicians and subspecialty consultants? Archives of Internal Medicine 1984;144:1265-1268.

Meinert CL. Clinical trials: design, conduct and analysis. New York: Oxford University Press, 1986.

Melker de RA. Samenwerking tussen huisarts en fysiotherapeut binnen de eerstelijns gezondheidszorg. Ned Tijdschr Fysiother 1981:9:254-60.

Melker de RA. Samenwerking tussen de eerste- en tweedelijn in de gezondheidszorg. In: Peters JH [red.]. Management in de gezondheidszorg. Utrecht/Antwerpen: Bohn, Scheltema \& Holkema, 1986.

Mielenz TJ, Carey TS, Dyrek DA, et al. Physical therapy utilization by patients with acute low back pain. Phys Ther 1997;77:1040-1051.

Ministerie van WVC. Over de ontwikkelingen van gezondheidsbeleid: feiten, beschouwingen en beleidsvoornemens (Nota-2000). Rijswijk, 1986.

Ministerie WVC. Notitie Ontwikkeling Fysiotherapeutische Hulpverlening. Rijswijk, 1989.

Ministerie van Welzijn, Volksgezondheid en Cultuur (WVC). De Wet BIG; hoofdlijnen van de Wet Beroepen in de Individuele Gezondheidszorg. Rijswijk: Ministerie van WVC, 1994.

Mischner-van Ravensberg CD. Paauw HJM, Gestel van JLM. De fysiotherapeutische werkdiagnose in relatie tot de medische diagnose. Ned Tijdschr Fysiother 1988:98:104-107.

Mischner CD, Klaveren AAJ, Wams HWA, Elvers JWH, Oostendorp RAB, Hendriks HJM. Variabelen in samenhang met aantal behandelingen fysiotherapie. Amersfoort: NPi. 1995.

Moncur C. Perceptions of physical therapy competencies in rheumatology. Physical therapists versus rheumatologists. Phys Ther 1987:67(3):331-339.

Mulder Th. A process-oriented model of human motor behavior. Toward a theory-based rehabilitation approach. Phys Ther 1991:71:157-164.

Nagi SZ. Some conceptual issues in disability and rehabilitation. In: Sussman M (ed). Sociology and rehabilitation: 100-113. Washington DC: American, Social Association, 1965.

Nagi SZ. In: Granger CV. A conceptual model for functional assessment. In: Granger CV, Gresham. GE (editors). Functional assessment in rehabilitation medicine. Baltimore, Williams \& Wilkins, 1984:15-25.

Nederlands Huisartsen Genootschap (NHG). De verwijsbrief naar de Tweede Lijn - standaard 001 . Huisarts Wet 1988;32:102-105.

Nederlandse Pạtiënten/Consumenten Federatie (NP/CF) en Raad vộr de Volksgezondheid en Zorg (RVZ). Net van der J, Prakken AJB. Helders PJ. Correlates of disablement in polyarticular juvenile chronic arthritis; A cross-sectional study. Brit J. Rheumatol 1996:35:91-100. 
Newman DJ. Physiotherapy for best effect. Physiotherapy 1997;83:5-11.

Nieuwboer A, Weerd de W. Nuyens G, et al. Fysiotherapie en Parkinson: een review van de literatuur. Ned Tijdschr Fysiother 1994;104:122-128.

Nordin M. Education and return to work. In: Gunzberg R. Szpalski M (eds), Whiplash injuries: current concepts in prevention, diagnosis and treatment of the cervical whiplash syndrome. Philadelphia/New York: Lippincot-Raven Publishers, 1998.

Noteboom T, Cruver R, Keller J, Kellogg B. Nitz AJ. Tennis elbow: a review. JOSPT 1994;19: 357. 366.

NRV, Nationale Raad voor de Volksgezondheid. Discussienota "Begrippenkader voor de beroepsuitoefening", Zoetermeer: NRV, 1986.

NRV, Nationale Raad voor de Volksgezondheid. Discussienota substitutie in de gezondheidszorg. Zoetermeer, 1989.

NRV. Nationale Raad voor de Volkgezondheid. Nota indicatiestelling in de gezondheidszorg; nota inzake de indicatiestelling in de gezondheidszorg en de maatschappelijke dienstverlening. Publikatie 4/90. Zoetermeer: NRV, 1990.

NRV. Nationale Raad voor de Volksgezondheid. Discussienota 'Algemeen begrippen-kader kwaliteitsbevordering'. Zoetermeer, 1990.

NRV, Nationale Raad voor de Volksgezondheid. Naar een meer vraaggerichte zorg. Zoetermeer: NRV, 1998

O'Rahilly R, Muller F. The embryonic human brain. New York: Wiley-Liss, 1994.

Oerlemans HM. Oostendorp RAB, Boo de T, et al. Randomised controlled trial of adjuvant physiotherapy or occupational therapy in reflex sympathetic dystrophy / complex regional pain syndrome of the upper extremity. Pain (in press).

Onwuteaka-Philipsen BD, Kriegsman DMW, Wal van der G, Dillmann RJM, Eijk van JThM. General Practitioners'opinions on consultation of another physician in case of euthanasia. European Journal of General Practice 1999:5:137-143.

Ooij van A, Walenkamp GHIM, Gesink RGT, Arens HJ, Vierhout WPM, Knottnerus JA. Medisch Consultatie in de huisartspraktijk. 1. Een specialistische impressie. Medisch Contact 1992;47:118120.

Oostendorp RAB, Functionele Vertebrobasilaire Insufficiëntie [PhD thesis]. Nijmegen: Katholieke Universiteit Nijmegen (KUN), 1988.

Oostendorp RAB. Wams HWA, Bernards ATM. Understanding the basics of physical therapy: the main condition for improving the quality of physical therapy. In: Dekker J, Oostendorp RAB (eds). Improving the quality of physical therapy: invited lectures. Utrecht/Amersfoort: Netherlands institute of primary health care (Nivel)/Dutch national institute for the allied health professions (NPi), 1995.

Oostendorp RAB, Eupen. van AAJM, Elvers JWH, Erp van JMM. Physical therapy and the consequences of whiplash injury. In: proceedings of the 12th International Congress of the World Confederation for Physical Therapy, June 25-30. Washington DC, USA, 1995.

Oostendorp RAB, Ravensberg van CD, Wams HWA, Heerkens. YF, Hendriks HJM Fysiotherapie, wat omvat het? Bijblijven 1996;12:5-17.

Oostendorp RAB, Wams HWA, Hendriks HJM. Fysiotherapie en lage-rugpijn. Een nieuw paradigma. Ned Tijdschr Fysiother 1997:107:102-110.

Overman SS, Kent DL. Uslan DW, Lewis RS. Cost of care and patient-satisfaction from routine referral to nonsurgical musculoskeletal specialists in a medicare risk plan. Journal of Clinical Rheumatology 1998:4:120-128.

Owens DK. Patient preferences and the development of practice guidelines. Spine 1998:23:1073-1079. Partridge CJ. Editorial - The patient as decision maker. Physiotherapy Research International 1997:2:iv-vi.

Pashkow P. Outcomes in cardiopulmonary rehabilitation. Phys Ther 1996;76:643-656. 
Patterson L, Goldstein H. New statistical methods for analysing social structures: an introduction to multilevel models. British Educational Research Journal 1991;17:387-393.

Philipsen BD. Wal van der G, Eijk van. JThM. Consultatie bij euthanasie en hulp bij zelfdoding. Huisarts Wet 1994;37:478-481.

Pincus T. Assessing psychological factors in chronic pain - a new approach. Phys. Ther. Rev. 1998:3:41-45.

Plas van der CG, Dingjan RA, Hamel A, et al. NHG-Standaard Traumatische Knieproblemen. Huisarts Wet 1998;41:296-300.

Pocock SJ. Clinical trials: a practical approach. Chichester: Wiley \& Sons, 1991.

Pool JB, Hingstman L. Cijfers uit de registratie van beroepen in de eerstelijnsgezondheidszorg. Statistische gegevens per 1 januari 1991 over huisartsen en verloskundigen. Utrecht: Nivel, 1992.

Pool JB, Hingstman L. Cijfers uit de registratie van beroepen in de eerstelijnsgezondheidszorg 1991. Statistische gegevens per 1 januari 1991 over in de eerste lijn werkzame fysiotherapeuten Utrecht: Nivel, 1993.

Pop P. Consultatie eerste-tweede lijn. Drie jaar Diagnostisch Centrum Maastricht. Medisch Contact. 1982:37:1019-23.

Pop P, Kerkhof PD. Diagnostisch Centrum Maastricht: Eindevaluatie van een experiment. Medisch Contact 1984;39:749-52.

Pop P. Beusmans GHMI, Knottnerus JA. Een diagnostisch centrum voor Maastricht. Versterking van de eerste lijn en samenwerking huisarts-specialist. Medisch Contact 1987:42:845-848.

Pop P. Winkens RAG. A diagnostic centre for general practitioners: results of individual feedback on diagnostic actions. JR Coll Gen Pract 1989;39:507-509.

Post D, Zanten van A. Hoe nodig is fysiotherapie? Medisch Contact 1992;19:590-593.

Posthuma BH, Zee van der J. Verwijscijfers en de verkleining van de huisartspraktijk. Gezondheid en Samenleving 1980; 1:59-68.

Prescot-Clarke P. Brooks T, Machray C. Focus on health care: surveying the public in four health care districts. London: Royal institute of Public administration and Social and Community Planning Research, 1988.

Prosser R, Rasbash J, Goldstein H. ML\# Software for three-level analysis. User's guide for V.2. London: University of London, Institute of education, 1991.

Raad voor Gezondheiđssonderzoek (RGO). Advies Medical Technology Assessment (Deel 1). Inventarisatic van MTA-onderzoek en aanzet tot coordinatie. Rijswijk: RGO, 1998.

Raad voor Maatschappelijke Ontwikkelingen (RMO)/Raad voor de Volksgezondheid en Zorg (RVZ). Achtergrondstudies bij het advies zorgarbeid in de toekomst, Den Haag/Zoetermeer: RMO/RVZ. 1999.

Raad voor de Volksgezondheid en Zorg (RVZ). Redesign van de eerste lijn in transmuraal perspectief. Zoetermeer: RVZ, 1998 .

Raad voor de Volksgezondheid en Zorg (RVZ). Professionals in de gezondheidszorg. Zoetermeer: RVZ, 1998.

Raad voor de Volksgezondheid en Zorg (RVZ). Naar eert meer vraaggerichte zorg. Zoetermeer: RVZ. 1998 .

Raad voor de Volksgezondheid en Zorg (RVZ), Transmurale zorg: redesign van het zorgproces. Zoetermeer: RVZ, 1998.

Raad yoor de Volksgezondheid en Zorg (RVZ). Prikkels tot dọelmatigheid. Zoetermeer: RVZ, 1998. Rasbach J, Woodhouse G. MLA Command reference. London. England: Institute of Education, University of London, 1995.

Ravensberg van CD. Klaveren van A.AJ, Wams HWA, et al. Variabelen in samenhang met aantal behandelingen fysiotherapie: analyse FON-PPP-gegevens. Amersfoort: Nederlands Paramedisch Instituut (NPi), 1995. 
Ravensberg van der CD, Wams HWA, Oostendorp RAB. Zicht. op fysiotherapie: prognose aantal behandelsessies gekoppeld aan doelstellingen en resultaten na 9. sessies. Amersfoort: Nederlands Paramedisch Instituut (NPi), 1996.

Reynolds D, Chitnis JE, Roland MO. General practitioners referrals: do good doctors refer more patients to the hospital? BMJ 1991:302:1250-1252.

Rijdt van der T, Lubbers M, Kolker L. Het verbeteren van samenwerking. Eindverslag van het project Samenwerking huisarts en fysiotherapeut. Utrecht: Stichting O\&O, 1990.

Rijken PM, Heugten van CM, Dekker J. Brancherapport paramedische zorg. Utrecht: Nederlands instituut voor onderzoek van de gezondheidszorg (Nivel), 1996.

Rijksinstituut voor de Volksgezondheid en Milieu (RIVM). Volksgezondheid Toekomstverkenningen 1997. Effecten van zorg. Bilthoven: Elsevier/de Tijdstroom, 1997.

Ritchey FJ, Pinkston D, Goldbaum JE, Heerten ME. Perceptual correlates of physician referral to physical therapist: Implications for role expansion. Soc Sci Med 1989;28:69-80.

Roach KE, Ally D, Finnerty B, Watkins D, Litwin BA, Janz-Hoover B, Watson T, Curtis KA. The relationship between duration of physical therapy services in the acute care setting and change in functional status in patients with lower-extremity orthopedic problems. Phys Ther 1998:78:19.24.

Robeer GG, Brandsma JW. Heuvel van den S, et al. Exercise therapy for intermittent claudication; a review of the quality of randomized clinical trials and evaluation of predictive factors. Eur J Vasc Endovasc Surg 1998;15:36-43.

Roebroeck ME, Hutten JBF, Kerssens JJ, Dekker J. De omvang vani de fysiotherapeutische behandeling naar verschillende patiēntencategorieèn. Utrecht: Nederlands instituut voor onderzoek van de gezondheidszorg (Nivel). 1995

Roebroeck ME, Dekker J, Oostendorp RAB, Bosveld W. Physiotherapy for patients with lateral ankle sprains. A prospective survey of practice patterns in Dutch Primary health care: Physiotherapy 1998:84:421-432.

Roland M. General practitioners referral rates, interpretation is difficult. BMل 1988;297:437-438.

Rose SJ. Physical therapy diagnosis: role and function. Phys Ther 1989;69:535-537.

Rothstein JM. Science and practice: examining outcomes. In: Dekker J, Oostendorp RAB (eds). Improving the quality of physical therapy: invited lectures. Utrecht/Amersfoort: Netherlands institute of primary health care (Nivel)/Dutch national institute for the allied health professions (NPi), 1995.

Rothstein JM. Editor's note - When thoughtfulness dies. Phys Ther 1996;76:342-343.

Rowland MO, Porter R. Matthews. JG et al. Improving care: a study oforthopaedic out-patient referrals. BMJ 1991;302:1124-1128.

Royal College of General Practitioners (RCGP). Clinical guidelines for the management of acute low back pain. London: RCGP, 1996.

Sackett DL, Hayes, RB, Guyatt GH, Tugwell P. Clinical Epidemiology. A basic science for clinical medicine (2e edition). Boston: Little, Brown and Company, 1991.

Sackett DL, Richardson WS, Rosenberg WMC, Haynes RB. Evidence-based medicine. New York: Churchill Livingstone, 1997.

Sackett DL, Weinberg JE. Choosing the best research design for each question. BM! 1997:315:1636.

Sahrmann SA. Diagnosis and classification by physical therapist: a special communication. Phys Ther 1988:11:1703-06.

Sahrmann SA. Moving precisely? Or taking the path of least resistance? Phys Ther 1998;78:12081218.

Saunders C, Maxwell M. The case for counseling in physiotherapy. Physiotherapy 1988;74:592-596. Schayk van CP. Rutten MPMH, Boom van den G, et al. Longfunctie en ervaren gezondheid bij patiënten met astma en chronisch obstructieve longziekten in longitudinaal onderzoek. Huisarts Wet 1995:38:129-131.

Scholte op Reimer WJM, Haan de RJ, Limburg M, Bos van den GAM. Tevredenheid over zorg van patiënten met een beroerte. TSG 1997;75:511-517. 
Schoutsen HJA. Statistical Measurement of Inter-observer Agreement: Analysis of Agreements and

Disagreements Between Observers. Dissertation University of Utrecht. Elinkwijk, 1985.

Schuurman W, Alphen van-Jager JM, Bosch van den WJHM, et al. NHG-Standaard Reumatoide Artritis. Huisarts Wet 1994;37:248-259.

Sladden MJ, Gragam-Brown RAC. How many GP referrals to dermatology outpatients are really necessary? J Soc Med 1989;89:347-348.

Sluijs EM, Zee van der J, Kok GJ. Differences between physical therapists in attention paid to patient. education. Physiother Theory Prac 1992;9:103-117.

Sluijs EM, Bakker D. De ontwikkeling van kwaliteitssystemen in de fysiotherapie. Ned Tijdschr Fysiother. 1993:103:13-18.

Sluijs EM, Bakker de DH, Dronkers J. Kwaliteitssystemen in uitvoering. Utrecht: Nivel, 1994.

Sluijs EM, Kerssens JJ, Zee van der J. Adherence to physiotherapy. In: Myers L, Midence K (eds). Adherence to medical treatment. Harwood Academic Publishers: Reading (England), 1998.

Smeele IM, Hoogen van den JMM, Mens JMA, et al. NHG-Standaard Lumbosacraal Radiculair Syndroom. Huisarts Wet 1996;39:78-89.

Smit de DJ. Consultatie huisarts-specialist. Experiment bij kinderen met luchtwegproblemen. Medisch Contact 1987:42:849-852

Smit de DJ. Ervaringen met consultatiebijeenkomsten. Medisch Contact 1990;47:1413-1415.

Smits-Engelsman BCM. Theory-based diagnosis of the fine-motor coordination development and deficiencies using handwriting tasks (PhD thesis). Nijmegen: NICl, 1995.

Smits-Engelsman BCM. Bekkering GE, Hendriks HJM. KNGF-richtlijn Osteoporose. Amersfoort: $\mathrm{KNGF} / \mathrm{NPi}, 2000$

Snijders CJ. Nordin M, Frankel VH. Biomechanica van het spier-skeletstelsel: grondslagen en toepassingen. Utrecht: Lemma, 1995.

Spitzer WO, Skovron ML, Rachid Salmi, et al. Scientific monograph of the Quebec Task Force on whiplash associated disorders: redefining 'whiplash' and its management. Spine 1995;20: no. 8s.

Stanton PE, Fox FK, Francois KM. Hoover DH, Spilecki GM. Assessment of resident physicians' knowledge of physical therapy. Phys Ther 1985:65:27-30.

Stichting Toekomstscenario's Gezondheidszorg (STG). Managed care and disease management. Zoetermeer: STG, 1997.

Stokx LJ, Bakker de DH, Delnoy DMJ, Gloerich ABM, Groenewegen PP. Verwijscijfers belicht. Utrecht: Nivel, 1992.

Stokx L, Gloerich ABM. Kersten TJJMT. Kostenbesparing door kwaliteitsbevordering. Utrecht: Nivel, 1992.

Stovner L. The nosologic status of the whiplash syndrome: a critical review based on a methodological approach. Spine 1996:21:2735-2746.

Suijlekom van-Smit LWA, Crone-Kraaijeveld E. Het zieke kind, een zorg voor huisarts en kinderarts [Dissertatie]. Rotterdam: Erasmus Universiteit Rotterdam, 1994.

Swanson G. Use of outcome reports: justifying the need for physical therapy services. Orthopaedic Physical Therapy Clinics of North America 1995;4:253-268.

Triet van EF, Dekker J, Kerssens JJ, Curfs EChr. Reliability of the assessment of impairments and disabilities in survey research in the field of physical therapy. Int Disabil Stud 1990:12:61-65.

Tulder van MW. Diagnostics and treatment of chronic low back pain in primary care ( $\mathrm{PhD}$ Thesis). Amsterdam: Vrije Universiteit (VU), 1996.

Tulder van MW, Koes BW, Bouter LM. Conservative treatment of acute and chronic nonspecific low back pain. A systematic review of randomized controlled trials of the most common interventions. Spine 1997:22:2128-2156. 
Turk DC. The role of demographic and psychosocial yellow flags in physiosocial factors in transition from acute to chronic pain. In: Jensen TS. Turner JA. Wisenfeld-Hallin Z (eds). Proceedings of the eight World Congress on Pain, Progress in Pain Research and Management, pp 185-213. 8 IASP Press: Seattle, 1997.

Turner PA, Whitfield TWA. Physiotherapists' reasons for selection of treatment techniques: a crossnational survey. Physiother Theory Prac 1999;15:235-246.

Twoney LT. Editorial-Research, more essential than ever. Physiotherapy Research International 1996;1:iii-iv, Uili RM, Shepard K, Savinar E. Physician knowledge and utilization of physical therapy procedures. Phys Ther 1984;64:1523-1530.

Uili RM, Wood R. The effect of third-party payers on the clinical decision making of physical therapists. Soc Sci Med 1995:40:873-879.

Urinary Incontinence Guidelines Panel. Urinary incontinence in adults: clinical practice guideline. AHCPR pub, no. 92-0038. Agency for Health Care Policy and Research, Public Health Service, US Department of health and Human services, Rockville, MD, 1992.

Uunk W, Dekker J, Groenewegen P. Verwijzingen van huisartsen naar fysiotherapeuten: morbiditeitsspecifieke verwijspercentages. Deelproject Huisarts en fysiotherapeutische zorg: Basisgegevens uit de Nationale Studie van Ziekten en Verrichtingen in de Huisartsenpraktijk. Utrecht: Nivel, 1991.

Uunk WJG, Groenewegen PP, Dekker J. Verwijzingen van huisartsen naar fysiotherapeuten: een verklaring en analyse van, verschillen tussen huisartsen. Mens en Maatschappij 1992:67:389-411.

Valk van der R, Dekker J, Boschman M. Basisgegevens extramurale fysiotherapie 1989-1992. Gegevens uit het project Beleidsgericht Evaluatie- en Effectonderzoek Fysiotherapie (BEEF). Utrecht: Nivel, 1995.

Vandenbroecke JP. Case reports in an evidence-based world. JR Soc Med 1999:92:159-193

Velden van der J. Bakker de DH, Claessens AAMC, Schellevis FG. Nationale studie naar ziekten en verrichtingen in de huisartsenpraktijk. Basisrapport: Morbiditeit in de huisartsenpraktijk. Netherlands institute of primary health care (Nivel): Utrecht, 1991

Velden van der LFJ, Hingstman L. Groenewegen PP. Verkenning van vraag- en aanbodontwikkelingen binnen de medische en paramedische zorg: knelpunten en oplossingen. In: Velden van der LFJ, Hingstman L, Groenewegen PP. Verkenning van vraag- en aanbodontwikkelingen binnen de medische en paramedische zorg: knelpunten en oplossingen. In: Raad voor Maatschappelijke Ontwikkelingen (RMO)/Raad voor de Volksgezondheid en Zorg (RVZ). Achtergrondstudies bij het advies zorgarbeid in de toekomst, Den Haag/Zoetermeer: RMO/RVZ. 1999.

Verbrugge LM. Jette: AM. The disablement process. Soc Sci Med 1994:38:1-14

Verbrugge LM, Gruber Baldini AL, Fozard JL. Age differences and age changes in activities: Baltimore longitudinal study of Aging. J Gerontol B Psychol Sci Soc Sci 1996;51:S30-41.

Verhaak PFM, Collijn D. Wijkel D. Feltz van der-Cornelis CM. Huijse F. Psychiatrisch consult in de huisartspraktijk. Medisch Contact 1994;49:1319-132I

Verhagen AP, Sijpkes P, Vet de HCW. Prognose van whiplash: een literatuuronderzoek. Ned Tijdschr Fysiother 1996;106:142-148.

Verhagen AP, Sijpkes P, Vet de HCW. Behandeling van whiplash: een systematische review. Ned Tijdschr Fysiother 1996; 106:135-141.

Verhagen AP, Vet de HCW. Bie de RA, et al. The Delphi list: a criteria list for quality assessment of randomized clinical trials for conducting systematic reviews developed by Delphi consensus. J Clin Epid 1998;51:1235-1241.

Verhoeven AL. Heuvel van den CMF. KNGF-Richtlijn informatieverstrekking huisarts. Amersfoort: Koninklijk Nederlands Genootschap voor Fysiotherapie (KNGF), 1997.

Verhulst FJCM. Burgt van den MCA. Lindner K. Concretisering van patiëntenvoorlichting in het fysiotherapeutisch handelen. Ned Tijdschr Fysiother 1994;104:10-17. 
Vet de H, Bie de R, Bouter LM, et al. Systematic reviews on the basis of methodological criteria. Physiotherapy 1997;83:284-289.

Vierhout W. Gezamenlijk consult huisarts-specialist. Medisch Contact 1987:42:106-109.

Vierhout WPM. Het gezamenlijk consult van huisarts en specialist in de eerste lijn. Een nieuwe werkwijze bij klachten van het bewegingsapparaat [Dissertatie]. Maastricht: Rijksuniversiteit Limburg, 1994.

Vierhout WPM, Knottnerus JA, Ooij van A, Crebolder HFJM, Pop P, Wesselingh-Megens AMK, Beusmans GHMi. Effectiveness of joint consultation sessions of general practitioners and orthopaedic surgeons for locomotorsystem disorders. Lancet 1995;346:990-994.

Visser AP. Education in the hospital: differences in satisfaction, cognition, and emotional status between younger and older patients. Tijdschr Gerontol Geriatr 1988;19:113-119.

Vlacyen JWS. Chronic low back pain. assessment and treatment from a behavioral rehabilitation perspective (PhD thesis). Maastricht: Maastricht University, 1991.

Vlacyen JWS, Kole-Snijders AMJ, Boeren RGB, Eek van H. Fear of movement / (re)injury in chronic low back pain and its relation to behavioral performance. Pain 1995;62:363-372.

Vogels EMHM, Hendriks HJM, Baar van ME, Dekker J, Hopman-Rock M, Oostendorp RAB, Hullegie WAMM, Bloo H, Hilberdink WKHA, Munneke M, Verhoef J. KNGF-richtlijn "Artrose heup - knie". Amersfoort: KNGF/NPi, 2000.

Waddell G. The Back Pain Revolution. Churchill Livinstone: Edingburgh, 1998.

Walma EP, Bakx HCA, Besselink RAM, et al. NHG-Standaard Hartfalen. Huisarts Wet $1995 ; 38: 471-487$.

Watkinson A, Gargan MF, Bannister GC. Prognostic factors in soft tissue injuries of the cervical spine. Injury 1991:22:307-309.

Watson PJ. Psychosocial assessment. The emergence of a new fashion, or a new tool in physiotherapy for musculoskeletal pain? Physiotherapy 1999;85:530-535.

Wellman B. Lay Referral Networks: using conventional Medicine \& Alternative Therapies for low back pain. Research in the Sociology of Health Care 1995;12:213-238.

Wijden van der $\mathrm{CL}$, Overbeke AJPM. Gerandomiseerde klinische trials in het Nederlands Tijdschrift voor Geneeskunde. Ned Tijdschr Geneeskd 1993;137:1607-1610.

Werken aan zorgvernieuwing :actieprogramma van het beleid voor de zorgsector in de jaren negentig: bijlage: notitie inzake stelselwijzigingen zorgsector. Tweede Kamer, vergaderjaar 1989-1990, 21 545, no's $1-2$.

Wersch-van der Spek MCM. De. verpleeghuisarts als medisch consulent in de eerstelijnsgezondheidszorg. Medisch Contact 1987;42:1243-1244.

Wersch-van der Spek MCM van der. Ervaringen met de consultatiefunctie van het verpleeghuis in het verzorgingshuis. Medisch Contact. 1990;45:385-87.

Wet op de Paramedische Beroepen: Wet van 21 mrt 1963 stb.113, laatstelijk gewijzigd bij de Wet van 23 juni 1976, stb. 377.

WHO (World Health Organization). International Classification of Impairments, Disabilities, and Handicaps (ICIDH): a manual of classification relating to the consequences of disease. WHO: Geneva, 1980 .

WHO (World Health Organization). International Classification of Impairments, Activities and Participation: a manual of dimensions of disablement and functioning (ICIDH-2). WHO: Geneva, 1997.

Whyte J. Toward a methodology for rehabilitation research. Am J Phys Med Rehabil. 1994:73:428435.

Wijkel D. Lower referral rates for integrated health centres in The Netherlands. Health Policy 1986:6:185-98.

Wilkin D. Smith A. Explaining variation in general practitioners referrals to hospital. Fam Prac. 1987:4:160-169. 
Wilkin D. Metcalfe DH, Marinker M. The meaning of information on general practitioners referral rates to hospitals. Community Med 1989;11:65-70.

Wilkin D, Hallam L, Doggett M. Measures of need and outcome for primary health care. Oxford: Oxford University Press, 1992.

Willemse JMA, Fiolet FFBM, Geriatrie in de periferie. Medisch Contact 1989;44:715-717.

Windt van der, Koes BW, Boeke AJP, et al. Shoulder disorders in general practice: prognostic indicators of outcome. Br J Gen Pract 1996:46:519-523.

Windt van der DAWM, Koes BW, Boeke AJP, Deville W, Jong de B, Bouter LM. Shoulder disorders in general practice: prognostic indicators of outcome. Br J Gen Prac 1996:46:519-523.

Wingerden van BAM. Connective tissue in rehabilitation. Vaduz, Liechtenstein: Scipro Verlag, 1995

Winter. F. De pijn de baas. Soest: RuitenbergBoek, 2000.

Winters JC, Jongh AC. Windt van der DAWM, et al. NHG-Standaard Schouderklachten. Huisarts Wet 1999:42:222-231.

Wolff $\mathrm{N}$. Professional uncertainty and physician medical decision-making in a multiple treatment framework. Soc Sci Med 1989:28:99-107.

Wong WP, Galley P. Sheehan M. Changes in medical referrals to an outpatient physiotherapy department. Australian Physiotherapy. 1994:40(1):9-14.

Yardley L, Beech S, Zander L, Evans T, Weinman J. A randomized controlled trial of exercise therapy for dizziness and vertigo in primary care. Br J Gen Pract 1998;48;1136- I 140.

Yelin E, Callahan L. The economic costs and social and psychological impact of musculoskeletal conditions. Arthritis Rheum 1995:38:1351-1362.

Yoshida KK, Allison KR. Sociodemographic and health-related characteristics of Ontarians making contact with physical therapists: analysis of the 1990 Ontario health survey. Physiotherapy Canada 1997:49:214-221.

Ziekenfondsraad. Financiëel Jaarverslag 1994. Amstelveen: Ziekenfondsraad, 1995.

Ziekenfondswet: Tekst van de wet van 15 okt. 1964, houdende regelen met betrekking tot de geneeskundige verzorging door middel van Ziekenfondsverzekering, stb. 392.

Zuijderduin W, Dekker $J$, Abrahamse H. Determinanten van de omvang van de behandeling in de extramurale fysiotherapie. TSG 1995;73:274-281, 


\section{List of Publications and Presentations emanating from this Thesis}

\section{Publications}

- Hendriks HJM, Brandsma JW, Wagner C, Dekker J. Consultatie van de fysiotherapeut in de eerste lijn. De Huisarts 1991;2:12-14.

- Hendriks HJM, Wagner C, Brandsma JW, et al. Het Consultatief Fysiotherapeutisch Onderzoek (CFO) in de eerste lijn. Informatie uit de literatuur en introduktie van het CFO-project. Ned Tijdschr Fysiotherapie $1992 ; 102: 176-183$.

- Hendriks HJM, Brandsma JW, Wagner C, Dekker J. Het Consultatief Fysiotherapeutisch Onderzoek (CFO) in de eerste lijn. Eindverslag fase 1. Stichting Wetenschap en Scholing Fysiotherapic, Amersfoort, 1992.

Hendriks HJM, Brandsma JW, Wagner C, et al. Eerste ervaringen met het Consultatief Fysiotherapeutisch Onderzoek. Resultaten van een pilot-studie. Ned Tijdschr Fysiotherapie 1993:103:190-200.

- Hendriks HJM, Brandsma JW, Wagner C. Consulatie van de fysiotherapeut. Een middel voor een betere samenwerking tussen huisarts en fysiotherapeut. In: Jaarboek Fysiotherapie/Kinesitherapie. Bohn Stafleu Van Loghum, Houten/Zaventem, 1993.

- Hendriks HJM, Wagner C, Dekker J, Brandsma JW, Evaluatie van het "Consultatief Fysiotherapeutisch Onderzoek (CFO)" - project. Resultaten van een veldexperiment. Nivel/NPi, Utrecht, december 1994.

- Hendriks HJM, Brandsma JW, Wagner C, Dekker J, Oostendorp RAB. Experiences with physiotherapy consultation. Results of a feasability study. Physiother Theory Prac 1996;12:211-220.

- Hendriks HJM, JW Brandsma, YF Heerkens, RAB Oostendorp, RM Nelson. Intraobserver and interobserver reliability of the assessments of impairments and disabilities. Phys Ther 1997:77:1097-1106.

- Hendriks HJM, KMM van Pelt, GE Bekkering, JW Brandsma, K Reynders, RAB Oostendorp. Het meten van de functionele gezondheidstoestand in termen van stoornissen en beperkingen. Resultaten van een (intraen interbeoordelaars) betrouwbaarheidsonderzoek. Ned Tijdschr Fysiotherapie 1998:108:2-10.

- Hendriks HJM, Oostendorp RAB, Bernards ATM, Ravensberg van CD, Heerkens YF, Nelson RM. The diagnostic process and indication for physical therapy: A prerequisite for treatment and outcome evaluation. Phys. Ther. Rev. 2000:5:29-47.

- Hendriks HJM, Kerssens J, Dekker J, Zee van der J, Oostendorp RAB, Nelson RM. Physiotherapy Consultation in General Practice. Its use and effect on referral pattern. Phys Ther (accepted).

- Hendriks HJM, Kerssens JJ, Elvers H, Dekker J, Oostendorp RAB, Zee van der J, Physiotherapist's consultation in general practice: utilization and efficiency of care. Physiother Theory Prac (accepted).

- Hendriks HJM, Kerssens JJ, Bekkering GE, Dekker J, Zee van der J, Oostendorp RAB. Determinants of the number of sessions per physiotherapy treatment episode (submitted).

- Hendriks HJM, van der Zee J, de Bie RA, Pop P. Consultation between general practitioners and medical consultants in the Dutch health care system. What can we learn from the literature? (submitted).

- Hendriks HJM, Kerssens. JJ, Dekker J. Oostendorp RAB, Zee van der J. Effecten van het Consultatief Fysiotherapeutisch Onderzoek (CFO). Resultaten van een veldexperiment (aangeboden). 


\section{Presentations}

- Hendriks HJM. Symposium 'Zorgvernieuwing in de praktijk' Hogeschool van Amsterdam. Consultatie van de fysiotherapeut. De procedure van het CFO en eerste resultaten van een pilot-studie. Amsterdam: 24 oktober, 1991.

- Hendriks HJM. KNGF-Jaarcongres 'Facetten van de praktijk'. Consultatie van de fysiotherapeut; resultaten van de pilot-studie. s'Gravenhage: 15-16 november, 1991.

- Hendriks HJM, Wagner C. GZO-dag. Posterpresentatie: CFO-procedure en resultaten van de pilot-studie. Amsterdam: 17 december, 1991. [Abstract in: TSG 1991;11]

- Hendriks HJM en Wagner C. NHG-referatendag. Posterpresentatic: CFO-procedure, resultaten van de pilotstudie en opzet van het veldexperiment. Groningen: 30 oktober, 1992.

- Hendriks HJM. Physiotherapist's Consultation: design of the study and preliminary results. Colloque Européen 'De l'analyse économique aux politiques de Santé. Interactive Poster presentation: Physical therapy consultation in primary health care. Paris: 16-18 december, 1992.

- Hendriks HJM. KNGF-Jaarcongres 'Effecten van Fysiotherapie, kwaliteit van bewegen - kwaliteit van leven'. Effecten van het consultatief Fysiotherapeutisch onderzoek, (CFO), in de eerste lijn. Resultaten van een veldexperiment. Den Haag: november 1993.

- Bekkering GE, Hendriks HJM. KNGF-Jaarcongres 'Efffecten van Fysiotherapie, kwaliteit van bewegen kwaliteit van leven'. Een streven naar eenduidigheid. Den Haag: november 1993.

- Hendriks HJM. Physical Therapy Consultation in primary care. International Conference: Improving the quality of physical therapy. s'Hertogenbosch: $2 \cdot 3$ june, 1994.

- Hendriks HJM, Dekker J. 12e GZO-dag. Consultatief Fysiotherapeutisch Onderzoek goed gewaardeerd door huisartsen. Rotterdam: 24 februari, 1995. [Abstract in: TSG 1995;1]

- Hendriks HJM. Wagner C. Dekker J, Brandsma JW. Consulting the Physical Therapist. Does it enhance the Efficiency in Primary Health Care. World Confederation for Physical Therapy Congress (WCPT 1995). Washington (DC): June 25-30, 1995.

- Hendriks HJM. KNGF-Jaarcongres 'Verantwoorde zorg'. Fysiotherapeut en kenmerken zijn belangrijke determinanten van de omvang van de zorg. Den Haag: 2-3 november, 2000. 


\section{Appendices}

\section{Formulieren van het Consultatief Fysiotherapeutisch Onderzoek (CFO) [Consultation forms]}

\section{Contents}

1. Verwijsformulier voor eenmalige consultatie van de fysiotherapeut [Consultation request form]

2. Registratieformulier voor patiëntgegevens

[Patient's personal and sociodemographic characteristics]

3. Registratieformulier voor het meten van de gezondheidstoestand [Patient's functional (health) status]

4. Fysiotherapeutische rapportage

[Physiotherapist's report form] 


\section{MEDISCHE GEGEVENS}

1. Hulpvraag van de patiēnt/voornaamste klachten:

2. Klachten sinds:

$\begin{array}{lll}\text { - klachten } & \mathrm{O} \text { constant } & \mathrm{O} \text { intermitterend } \\ \text { - recidiverend } & \mathrm{O} \text { ja } & \mathrm{O} \text { nee } \\ \text { - progressief } & \mathrm{O} \text { ja } & \mathrm{O} \text { nee } \\ \text { - trauma } & \mathrm{O} \text { ja } & \mathrm{O} \text { nee }\end{array}$

3. Aanvullende relevante medische gegevens:

O niet van toepassing

$O$ voorgeschiedenis:

O lichamelijk onderzoek:

O rỏntgen:

O laboratorium:

O medicatie/injectie:

O operaties:

O risicofactoren/comorbiditeit:

$O$ anders:

4. Op dit moment elders onder behandeling voor dezelfde aandoening?

$\mathrm{O}$ ja $\mathrm{O}$ fysiotherapie

$\mathrm{O}$ anders:

O nee 
Elders onder behandeling geweest voor dezelfde aandoening?
O ja O fysiotherapie
$O$ anders:
O nee

5. Andere relevante aspecten van het beleid tot op heden

6. Andere hulpverlening: $\mathrm{O} j \mathrm{ja} O$ huishoudelijke hulp

O gezinshulp

O wijkverpleging

O maatschappelijk werk

O RIAGG

O

O nee

7. Relevante psychosociale informatie:

8. (Voorlopige) diagnose/hypothese:

9. Vraagstelling ten behoeve van het consult:

10. Rapportage gewenst binnen.......dagen

datum: getekend: stempel




\section{Argumentatie voor het Consultatief Fysiotherapeutisch Onderzoek.}

O het vaststellen van de indicatie voor fysiotherapie

$O$ het verkrijgen van meer informatie t.a.v. de klachten

$\mathrm{O}$ second opinion $\mathrm{O}$ ter geruststelling van de patiēnt

$\mathrm{O}$ ter ondersteuning eigen beleid

$O$ ter voorkoming van een verwijzing

naar een medisch specialisme

O

$\mathrm{O}$ anders:

Indien de mogelijkheid van een CFO niet had bestaan hoe zou u dan vermoedelijk gehandeld hebben?
$\mathrm{O}$ behandelen/begeleiden door de huisarts zelf
O consultaanvraag
O collega huisarts
O fysiotherapeut
O medisch specialisme
O orthopedie
O neurologie
$\mathrm{O}$ reumatologie
$\mathrm{O}$ röntgenologie
0
$O$ verwijzing naar een
$\mathrm{O}$ orthopedie
O korte kaarı
medisch specialisme
O neurologie
$O$ lange kararı
$\mathrm{O}$ reumatologie
$\mathrm{O}$ rōntgenologie
$\mathrm{O}$

verwijzing naar een

O fysiotherapie

paramedicus

O oefentherapie Cesar

O oefentherapie Mensendieck

0

O gezamenlijk onderzoek huisarts/fysiotherapeut

$\mathrm{O}$ anders: 
CODE:

Naam:

Voorletters:

Geboortedatum:

Geslacht O V OM

Adres:

Woonplaats:

Postcode:

Tel:

Woonsituatie: $\quad \mathrm{O}$ alleenstaand

$\mathrm{O}$ samenwonend met

O ouders

$\mathrm{O}$ kind(eren)

$\mathrm{O}$ partner/echtgeno(o)t(e)

$\mathrm{O}$ anders

Hoogste opleiding:
O Basisonderwijs
O HAVO
O LBO
$\mathrm{O}$ HBO
O MAVO
o vwo
$\mathrm{O} \mathrm{MBO}$
O Universiteit

Beroep en/of functie:

Werkzaam: O ja
$\mathrm{O}$ nee
O AOW/VUT
O NWW
O AAW/WAO
O Ziektewet
O Anders:

Verzekeringsvorm:
O Particulier (incl. Publiekrechtelijk)
O Ziekenfonds
$\mathrm{O}$ geen 


\section{REGISTRATIEFORMULIER VOOR STOORNISSEN EN BEPERIKINGEN VAN DE}

\section{PATIËNT}

CODE FYSIOTHERAPEUT
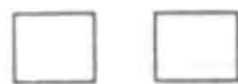

CODE PATIËNT
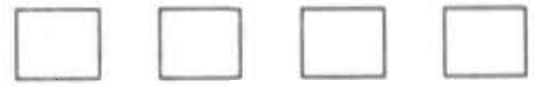
Geconstateerde stoornissen (A), ernst van de stoornis (B) en aangrijpingspunt van de fysiotherapeut (C).

\section{Pijn}

pijn na bewegen

pijn tijdens bewegen (dynamische belasting)

pijn in rust

pijn bij statische belasting (verminderd bij bewegen)

pijnbeleving (chagrijnig, benauwend, beangstigend)

pijngedrag (afwijkende houding, zuchten, kreunen)

\begin{tabular}{|c|c|}
\hline$A^{*}$ & B* \\
\hline ja / nee & \\
\hline ja / nee & \\
\hline ja / nee & 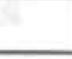 \\
\hline ja / nee & \\
\hline ja / nee & \\
\hline ja / nee & \\
\hline ja / nee & \\
\hline
\end{tabular}

\section{Stoornissen van het bewegingssysteem en in het bewegen}

afname bewegingsuitslag

toename bewegingsuitslag

gang (snelheid, patroon)

verminderde actieve stabiliteit

verminderde passieve stabiliteit

coördinatiestoornis

verhoogde spiertonus

verlaagde spiertonus

houdingsgevoel

bewegingsgevoel

verminderde spierkracht

trufische stoornis

houdingsafwijking

standsafwijking (knie, bekken, wervelkolom)

\begin{tabular}{|c|c|}
\hline ja / nee & ja. nee \\
\hline ja / nee & ja net \\
\hline ja / nee & ja nee \\
\hline ja / nee & ja nee \\
\hline ja / nee & ja nee \\
\hline ja / nee & ja nee \\
\hline ja / nee & ja neet \\
\hline ja / nee & ja nee \\
\hline ia / nee, & ,is nee \\
\hline ja / nee & ja / nee \\
\hline ja / nee & ja / nee \\
\hline ja / nee & ja / nee \\
\hline ja / nee & ja / nee \\
\hline ja / nee & $\mathrm{ja} /$ nee \\
\hline
\end{tabular}

\section{Huid- en sensibiliteitsstoornissen}

verschuifbaarheid, plooibaarheid

sensibiliteit (drukperceptie, pijn-, temperatuurzin)

\begin{tabular}{||c|l|l|}
\hline ja / nee & & ja / nee \\
\hline ja / nee & & $\mathrm{ja} / \mathrm{net}$ \\
\hline
\end{tabular}

\section{Inwendige stoornissen}

circulatie-/doorbloedingsstoornis

zwelling/oedeem

verhoogde slijmproduktie/bemoeilijkt transport

ademhaling (dyspnoe/hyperventilatie)

incontinentie (urine, faeces)

\begin{tabular}{||l|l|l|}
\hline $\mathrm{ja} / \mathrm{nee}$ & & $\mathrm{ja} / \mathrm{nee}$ \\
\hline $\mathrm{ja} / \mathrm{nee}$ & & $\mathrm{ja} / \mathrm{nee}$ \\
\hline $\mathrm{ja} / \mathrm{nee}$ & & $\mathrm{ja} / \mathrm{nec}$ \\
\hline $\mathrm{ja} / \mathrm{nee}$ & & $\mathrm{ja} / \mathrm{nee}$ \\
\hline $\mathrm{ja} / \mathrm{nee}$ & & $\mathrm{ja} / \mathrm{nec}$ \\
\hline
\end{tabular}

\section{Intellectuele en undere psychische stoornissen}

slaapstoornis

geheugenstoornis

angst

depressie

\begin{tabular}{|c|l|l|}
\hline ja / nee & & ja / nee \\
\hline ja / nee & & ja / nee \\
\hline ja / nee & & ja / nee \\
\hline ja / nee & & ja / nee \\
\hline
\end{tabular}

- A. omcirkelen wat van toepassing is (a.u.b. voor elke stoornis aangeven).

* B. ernst van de stoornis(sen) aangeven met: $1=$ matig, $2=$ ernstig, $3=$ zeer ernstig.

* $\mathrm{C}$. bij elke stoornis aangeven of deze aangrijpingspunt is voor de behandeling. 
Geconstateerde stoornissen (A), ernst van de stoornis (B) en aangrijpingspunt van de fysiotherapeut (C).

concentratiestoornis

Oog- en visusstoornissen

verminderde gezichtsscherpte (wazig zien)

Oor-, gehoor- en evenwichtsstoornissen

verminderde gehoorscherpte

duizeligheid (bij het opkomen, omkijken, lopen)

evenwichtsstoornis (bij het gaan, staan, zitten, draaien)

Algemene stoornissen

vermoeidheid

Andere niet vermelde stoornissen, $\mathrm{nl}$.

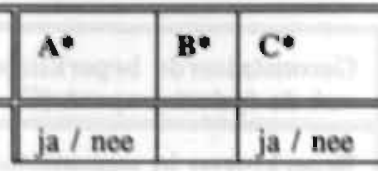

\begin{tabular}{|l|l|l|}
\hline ja / nee & & ja / nee \\
\hline
\end{tabular}

\begin{tabular}{|l|l|l|}
\hline ja / nee & & ja / nee \\
\hline ja / nee & & ja / nee \\
\hline ja / nee & & ja / nee \\
\hline
\end{tabular}

\begin{tabular}{|l|l|l|}
\hline ja / nee & & ja / nee \\
\hline ja / nee & & ja / nee \\
\hline
\end{tabular}

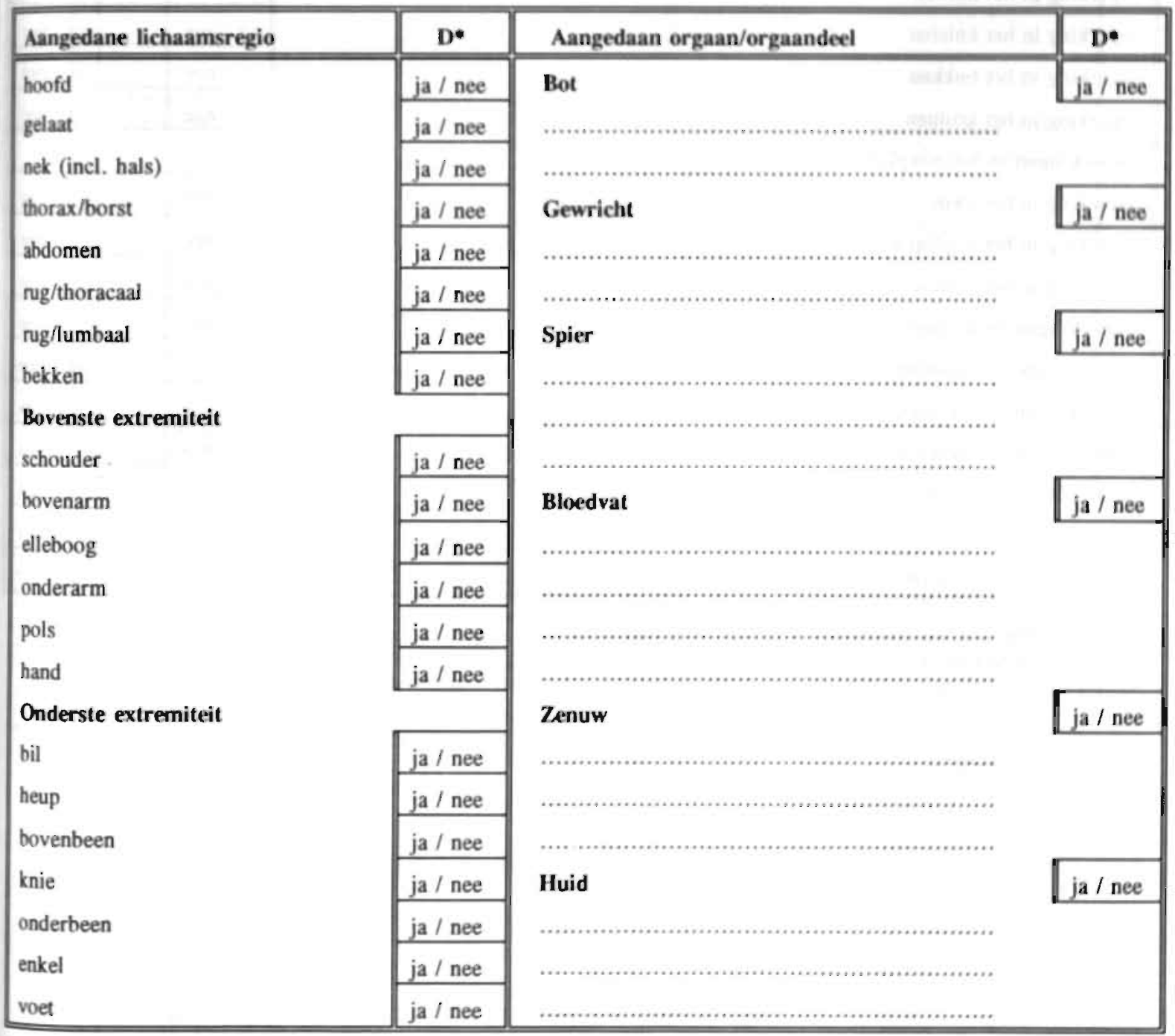

"A. omcirkelen wat van toepassing is (a.u.b. voor elke stoornis aangeven).

" $\mathrm{B}$. ernst van de stoornis(sen) aangeven met: $1=$ matig, $2=$ ernstig, $3=$ zeer ernstig.

"C. bij elke stoornis aangeven of deze aangrijpingspunt is voor de behandeling.

'D. omcirkelen wat van toepassing is (a.u.b. voor elke lichaamsregio en orgaan/orgaandeel aangeven). 
Geconstateerde beperkingen $(A)$, ernst van de beperkingen $(B)$ en aangrijpingspunt van de fysiotherapeut (C).

\section{Beperkingen in sensomotorische basisvaardigheden}

beperking in het handhaven van een lichaamshouding (lig, zit, stand)

beperking in het veranderen van een lichaamshouding (gaan liggen, zitten, staan)

beperking in het dragen

heperking in het tillen

beperking in het oprapen/oppakken

beperking in het reiken

beperking in het verplaatsen van voorwerpen

beperking in het omgaan met voorwerpen

beperking in het grijpen

beperking in het hurken

beperking in het knielen

beperking in het bukken

beperking in het kruipen

\begin{tabular}{|c|c|}
\hline ja / nee & ja / net \\
\hline ja / nee & ja / nee \\
\hline ja / nee & ja / nee \\
\hline ja / nee & ja / nee \\
\hline ja / nee & ja / nee \\
\hline ja / nee & ja / nee \\
\hline ja / nee & ja / nee \\
\hline ja / nee & ja / nee \\
\hline ja / nee & ja / nee \\
\hline ja / nee & ja / nee \\
\hline ja / nee & ja / nee \\
\hline ja / nee & ja / nee \\
\hline ja / nee & ja / nee \\
\hline
\end{tabular}

Beperkingen in het verplaatsen

beperking in het gaan

beperking in het traplopen

heperking in het fietsen

Beperkingen in de persoonlijke verzorging

Beperkingen in huishoudelijke bezigheden

Beperkingen met betrekking tot werk/arbeid

Beperkingen in recreatieve bezigheden

Beperkingen in psycho-sociale vaardigheden

Beperkingen in communicatieve vaardigheden

Andere niet aangegeven beperkingen, $\mathrm{nl}$.

\begin{tabular}{|c|c|}
\hline ja / nee & ja / nee \\
\hline ja / nee & $\mathrm{ja} /$ nee \\
\hline ja / nee & ja / nee \\
\hline ja / nee & ja / nee \\
\hline ja / nee & ja / nee \\
\hline ja / nee & ja / nee \\
\hline ja / nee & ja / nee \\
\hline ja / nee & ja / nee \\
\hline ja / nee & ja / nee \\
\hline ja / nee & ja / nee \\
\hline
\end{tabular}

* A. omcirkelen wat van toepassing is (a.u.b. voor elke beperking aangeven).

* B. ernst van de beperking(en) aangeven met: $1=$ matig, $2=$ ernstig, $3=$ zeer ernstig.

* C. bij elke beperking aangeven of deze aangrijpingspunt is voor de behandeling.

\section{Aanvullende gegevens:}




\section{CONCLUSIE FYSIOTHERAPEUT}

1. O Consult niet afgerond, vanwege:

2. Is fysiotherapie geindiceerd?
O ja
O nee (exclusief contra-indicatie)
$\mathrm{O}$ contra-indicatie

\section{AANBEVELING FYSIOTHERAPEUT}

$\mathrm{O}$ begeleiden/behandelen door de huisarts zelf

$\mathrm{O}$ consult van specialisme, nl.
O orthopedie
$\mathrm{O}$ neurologie
O reumatologie
$\mathrm{O}$ rôntgenologie
O

$\mathrm{O}$ verwijzing naar specialisme, $\mathrm{nl}$.

O orthopedie

O neurologie

O reumatologie.

O röntgenologie

O

O consult fysiotherapeut met bijzondere

O manuele therapie

bekwaamheden

O fysiotherapie in de sportgezondheidszorg.

O fysiotherapie in de pre-en postnatale gezondheidszorg

O fysiotherapie en geriatrie

O fysiotherapie in de kinder- en jeugd-

$\mathrm{O}$ gezondheidszorg

$\mathrm{O}$ verwijzing naar paramedicus, $\mathrm{nl}$.

O fysiotherapie

$\mathrm{O}$ oefentherapie Mensendieck

O oefentherapie Cesar

O

O gezamenlijk onderzoek huisarts/fysiotherapeut

$\mathrm{O}$ anders, $\mathrm{nl}$

4. Is de belasting en/of de belastbaarheid van de patiênt veranderd?

a. de algemene belasting (bijv. werkdruk, beroep, hobby, thuissituatie)
O hoog
O normaal voor die persoon
O laag

b. de regionale belasting (bijv. verandering in de lichamelijke belasting)
O hoog
O normaal voor die persoon
O laag

c. de algemene belasthaarheid (bijv. griep, prikkelbaarheid, concentratiestoornis)
O hoog
O normaal voor die persoon
O laag

d. de regionale belastbaarheid (bijv. eerder letsel in dezelfde regio)
O hoog
O normaal voor die persoon
O laag 
5. Wilt u een prognose geven over het fysiologisch herstelproces van de stoornissen van de patiēnt?

O volledig herstel

O gedeeltelijk herstel

O stabiliseren functieniveau

O niet in te schatten

$\mathrm{O}$ anders, $\mathrm{nl}$.

6. Wilt u een prognose geven over het functioneel herstelproces van de beperkingen van de patiënt?

O volledig herstel

O gedeeltelijk herstel

O stabiliseren functieniveau

O niet in te schatten

$\mathrm{O}$ anders, ni.

7. Wilt u een prognose geven van het aantal noodzakelijke behandelingen?

Duur van de behandelperiode:

O I - 3 behandelingen

$\mathrm{O}_{4}$ - 6 behandelingen

$07-12$ behandelingen

O $13-18$ behandelingen

O $19-24$ behandelingen

$O>24$ behandelingen

$O$ niet in te schatten

$\mathrm{O}$ anders, $\mathrm{nl}$.

\section{OPMERKINGEN:}


Naam patiênt:.

Geboortedatum:

Adres:

CONSULTVRAAG VAN DE HUISARTS:

\section{FYSIOTHERAPEUTISCHE BEVINDINGEN}

Hulpvraag van de patiênt:

Anamnestische gegevens:

Onderzoeksbevindingen:

Betekenis in termen van stoornis(sen) en beperking(en):

CONCLUSIES/AANBEVELINGEN: (Indien advies fysiotherapie: einddoelen formuleren, verwachte aantal behandelingen aangeven en prognose vermelden) 


\section{Dankwoord}

Het proefschrift is af! Het werk overziende, was het niet altijd een even boeiende en inspirerende ontdekkingsreis maar vaak ook een biopsychosociaal belastende klus, en zonder de mentale steun van velen had ik het niet geklaard. Vanuit dat perspectief gezien zou een dankwoord als voorwoord beter op zijn plaats zijn geweest. De bijdrage van iedereen die hierna wordt genoemd, maar ook voor de bijdrage van al diegenen die hier zeker thuishoren maar slachtoffer zijn geworden van de zeef dat mijn geheugen heet, ben ik woorden van dank verschuldigd.

Dit dankwoord kan niet beginnen zonder me allereerst te richten op het thuisfront. Jenny, zonder jou was deze wetenschapper niet zo ver gekomen. Hoewel de planning geheel anders is verlopen dan ik je ooit heb voorgespiegeld had dit alles niet kunnen ontstaan zonder jouw steun. Jenny mijn dank is groot voor de ruimte die je mij ondanks je werk, je huishoudelijke maar vooral ook je vele organisatorische beslommeringen - hebt gegeven. Michelle, Simone en Nadine zijn er in de loop van het traject bijgekomen en hebben voor de nodige afleiding gezorgd al was ik in deze periode niet altijd een "rendabele" vader. Jullie aandacht en (meestal) vrolijke drukte waren voor mij belangrijk en makkte het voor mij gemakkelijker om het belang van dit alles te relativeren.

Hoewel dit proefschrift is gezegend met drie promotoren wil ik mijn dank als eerste richten aan Prof.dr. J. van der Zee voor de kans die ik heb gekregen om het onderzoek met een proefschrift af te ronden. Beste Jouke, bedankt voor je schijnbaar onuitputtelijke geduld en je vertrouwen (of in ieder geval gaf je me dat gevoel) dat het toch nog goed zou komen. Wat me van onze bijeenkomsten vooral is bijgebleven waren je steeds weer nieuwe ideeën en filosofische bespiegelingen over hoe het ook anders had gekund.

Beste Rob (Prof.dr. R.A.B. Oostendorp), tot heden heb jij een hoofdrol gespeeld in mijn carrière. Jij was het die me heeft overgehaald om bij het Nederlands Paramedisch Instituut (voorheen de Stichting Wetenschap en Scholing Fysiotherapie) te komen werken en mij de kans hebt gegeven om wetenschap met praktijk te kunnen combineren. Ik ben je uiterst dankbaar voor je vertrouwen en onvoorwaardelijke steun tijdens de laatste 10 jaar, je inbreng als promotor, je meer dan waardevolle bijdrage als co-auteur, maar vooral ook voor je vriendschap. 
Beste Joost (Prof.dr. J. Dekker), hoewel als laatste in het rijtje der promotoren was jouw bijdrage in mijn vorming tot wetenschapper zonder enige twijfel het grootst. Ik ben je veel dank verschuldigd voor je begeleiding en scholing tot wetenschapper.

Daarnaast wil ik je bedanken voor de snelheid en nauwkeurigheid waarmee je mijn concepten hebt gelezen en van commentaar hebt voorzien. De vakkundige wijze en het gemak waarmee je overbodige stukken tekst doorstreepte was voor mij wel eens teleurstellend, maar na het bestuderen van een aantal offertes voor het drukken van dit proefschrift, ben jij voor mij een voorbeeld van kosten-effectiviteit.

Verder wil ik Cordula Wagner en Wim Brandsma bedanken voor de prettige samenwerking en de vele goede adviezen gedurende het project. Ik denk met veel plezier terug aan de vele autoritten naar allerlei bijeenkomsten in den lande. Cordula en Wim, bedankt voor je betrokkenheid bij het project en jullie bijdrage in het schrijven van een aantal publikaties over het onderzoek.

Dr. A.W. Chavannes en Prof.dr. C.A. de Geus dank ik voor hun constructieve bijdrage, maar vooral voor hun wijze lessen in het huisartsgeneeskundig denken. De persoonlijke ontmoetingen waren voor mij telkens weer een stimulans.

Zonder iedereen bij naam te noemen will ik de collega's van het Nederlands Paramedisch Instituut, met name Ria Wams, Nol Bernards. Hans Elvers, Dorine van Ravensberg, Yvonne Heerkens, Sylvia van de Heuvel en Joke Smit, bedanken voor hun "jarenlange" betrokkenheid bij mijn promotieplannen en de plezierige werksfeer. Speciale vermelding verdienen Trudy Bekkering en Lisette Vogels, ofwel mijn rechteren mijn linkerhand bij de uitvoering van het richtlijnenprogramma. Zonder jullie extra hulp was er veel blijven liggen. Beste Trudy, ik ben dan ook blij dat jij mijn paranimf wilt zijn.

Jan Kerssens is mijn andere paranimf en is voor het welslagen van dit proefschrift van onschatbare waarde geweest. Jan, bedankt voor je hulp bij de hiërarchische multi-level verwerking van weerbarstige data, voor je deskundig en richtinggevend commentaar als co-auteur, maar vooral voor je steun in moeilijke tijden.

Prof.dr. P. Pop wil ik bedaniken voor zijn betrokkenheid bij dit proefschrift. Je gastvrije ontvangst in het Maastrichtse en de "waarschuwende" woorden van je vrouw zullen me altijd bijblijven.

Rob de Bie wil ik graag bedanken voor zijn co-auteurschap, zijn adviezen gedurende het traject, maar vooral voor de prettige samenwerking bij andere (al dan niet wetenschappelijke) projecten.

Jim en Renate Chadwick-Straver wil ik bedanken voor alle taalkundige correcties. Dat. dit een leesbaar boekje is geworden is mede aan jullie te danken.

De betrokken huisartsen, fysiotherapeuten en patiënten wil ik bedanken voor hun deelname aan de verschillende onderzoeken. Zonder jullie bijdrage was dit niet mogelijk geweest. 
Prof.dr. R.M. Nelson, as an admirer of your work to improve the quality of physiotherapy, I feel honoured for your willingness to participate in the committee for evaluation of this thesis. Dear Roger, thanks for your friendship.

De overige leden van de beoordelingscommissie, Prof.dr. H.F.J.M. Crebolder, Prof.dr. W.J.A. van den Heuvel, Prof.dr. C. Spreeuwenberg en Dr. A. de Wijer wil ik bedanken voor het lezen, beoordelen maar vooral voor het goedkeuren van mijn proefschrift.

Hoewel niet direct betrokken bij mijn proefschrift ben ik ook aan mijn collega's van het Instituut voor fysiotherapie "de Klepperheide" dank verschuldigd. Tegen wil en dank werden en worden jullie geconfronteerd met mijn poging om verschillende werkzaamheden te combineren en daarnaast ook nog "eens" te promoveren. Victorine en Helma, bedankt voor jullie creativiteit in de planning van mijn patiënten. Het boekje is af, maar ik vrees dat de soms chaotische "drukte" tijdens mijn aanwezigheid maar vooral ook tijdens mijn afwezigheid niet wezenlijk zal veranderen.

Erik Hendriks, november 2000 


\section{Curriculum vitae}

Erik Hendriks werd op 28 september 1958 te Veldhoven geboren. Hij is in 1989 gehuwd met Jenny de Fouw. Samen hebben zij drie dochters: Michelle, Simone en Nadine.

In 1978 behaalde hij het eindexamen Atheneum-B aan het Rythovius College te Eersel. Na zijn militaire dienstplicht startte hij in 1979 met de Hogere Beroepsopleiding tot Fysiotherapeut te Nijmegen. $\mathrm{Na}$ het behalen van het diploma fysiotherapie in 1983 , werkte hij als fysiotherapeut in een vrijgevestigde praktijk voor fysiotherapie "Blekershof" te BeekUbbergen en sinds 1 februari 1986 tot heden in het Instituut voor Fysiotherapie "de Klepperheide" te Druten, waarvan hij tevens lid is van de maatschap.

In 1984 startte hij met de nieuw ingerichte studie Algemene Geneeskunde - Gezondheidswetenschappen aan de Faculteit der Medische Wetenschappen van de Katholieke Universiteit Nijmegen (KUN) met als afstudeerrichtingen bewegingswetenschappen en epidemiologie. Voor zijn publicatie Effect van dexamethason-iontoforese bij patiënten mer tendopathieèn (1992), gebaseerd op zijn afstudeerproject, kreeg hij de KNGF Auteursprijs. Tijdens zijn studie was hij betrokken bij een aantal onderzoeks- en ontwikkelingsprojecten in de fysiotherapie en was hij lid van de Landelijke Researchkring Fysiotherapie.

In september $1990 \mathrm{kreeg}$ hij een aanstelling als projectleider - wetenschappelijk stafmedewerker bij het Nederlands Paramedisch Instituut (NPi), voorheen de Stichting Wetenschap en Scholing Fysiotherapie. Daarnaast was hij betrokken bij de onderzoekersopleiding "Verkort Bewegingswetenschappen" voor fysiotherapeuten aan de Universiteit Maastricht en is hij docent van een aantal na- en bijscholingsactiviteiten, waarvan "Scholing in Wetenschap" de belangrijkste is. $\mathrm{Na}$ een detachering van drie jaar bij het Nederlands instituut voor onderzoek van de gezondheidszorg (Nivel) werd hij in 1995 programmaleider Richtlijnen Fysiotherapie bij het NPi. Vanuit die functie is Erik betrokken bij een aantal externe projecten, zoals de (multidisciplinaire) consensus-richtlijnen onder auspiciën van het Kwaliteitsinstituut van de Gezondheidzorg (CBO) en de NHG-Standaarden van het Nederlands Huisartsen Genootschap (NHG).

Erik volgde aanvullende cursussen over epidemiologisch onderzoek bij Lex Bouter, Olli Miettinen en Kenneth Rothman. In 1995 volgde zijn registratie als Epidemioloog A.

Erik is betrokken bij het Cochrane Rehabilitation and Related Therapies Field, het CBO Cochrane-overleg en is lid van de Cochrane Incontinence Group. 


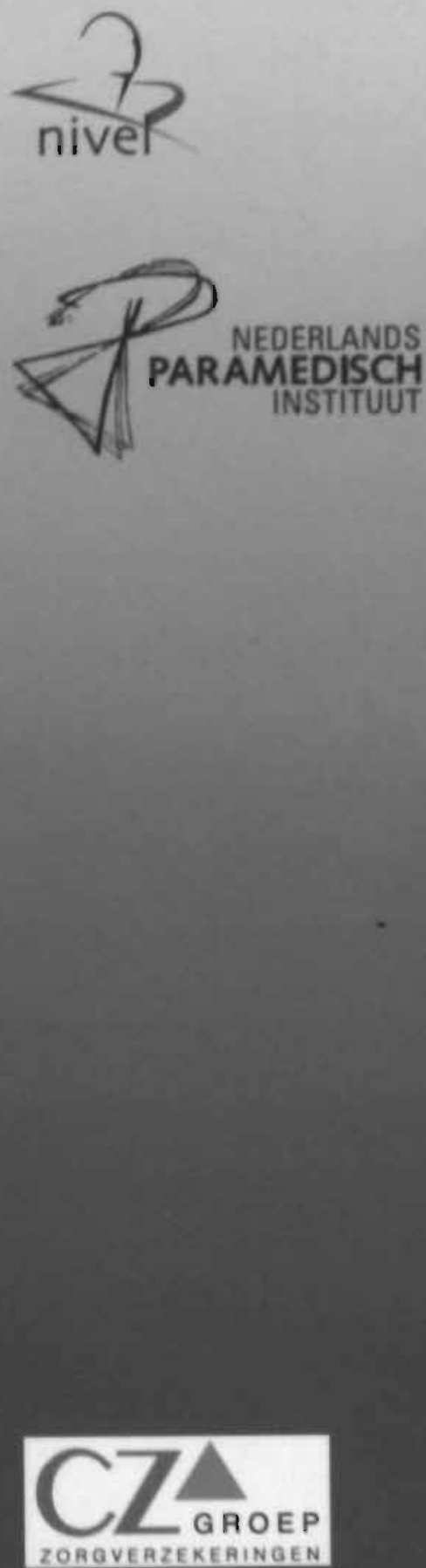

\section{Zorgverzekeraar SVGZ}

\section{Zorg en Zekerheid}

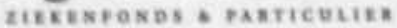
Veor alle zekerheid dichtbi]. 